\title{
CORRECTIVE ACTION DECISION DOCUMENT/CLOSURE REPORT FOR CORRECTIVE ACTION UNIT 559: T-TUNNEL COMPRESSOR/BLOWER PAD, NEVADA TEST SITE
}

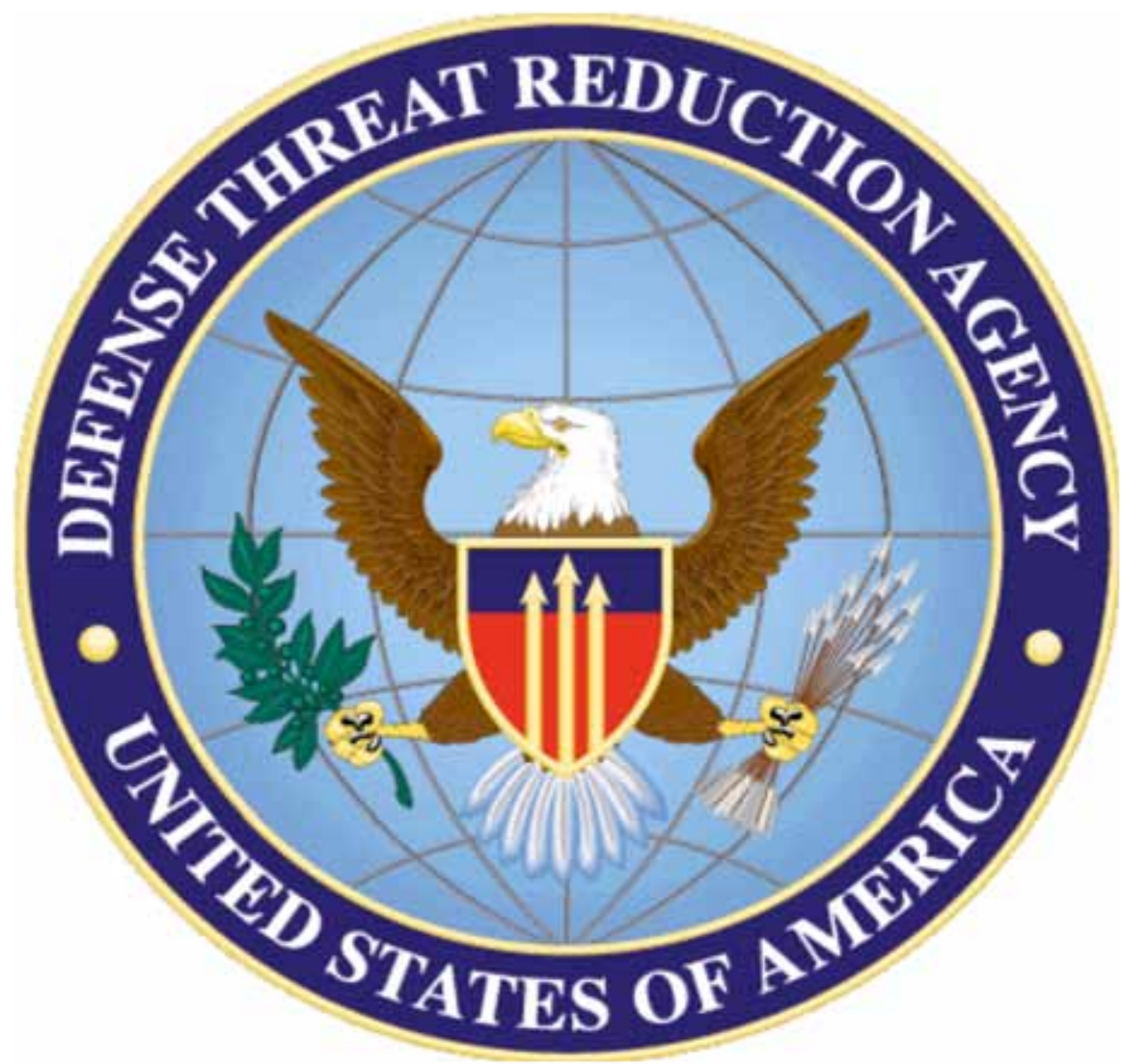

Controlled Copy No:

Revision No.: 0

November 2006

(Republished March 2010) 


\title{
DISCLAIMER
}

Reference herein to any specific commercial product, process, or service by trade name, trademark, manufacturer, or otherwise, does not necessarily constitute or imply its endorsement, recommendation, or favoring by the United States Government or any agency thereof.

This report has been reproduced directly from the best available copy.

Available for sale to the public from:

\author{
U.S. Department of Commerce \\ National Technical Information Service \\ 5301 Shawnee Road \\ Alexandria, VA 22312 \\ Telephone: (800) 553-6847 \\ Fax: (703) 605-6900 \\ E-mail: orders@ntis.gov \\ Online ordering: http://www.ntis.gov/help/ordermethods.aspx
}

Available electronically at http://www.osti.gov/bridge.

Available for a processing fee to the U.S. Department of Energy and its contractors, in paper, from:
U.S. Department of Energy
Office of Scientific and Technical Information
P.O. Box 62
Oak Ridge, TN 37831-0062
Telephone: (865) 576-8401
Fax: (865) 576-5728
E-mail: reports@adonis.osti.gov

(This document was republished. A front cover and back cover were added to reflect document numbers, disclaimer, availability, and library distribution. No other changes were made.) 


\title{
CORRECTIVE ACTION DECISION DOCUMENT/CLOSURE REPORT FOR CORRECTIVE ACTION UNIT 559: T-TUNNEL COMPRESSOR/BLOWER PAD, NEVADA TEST SITE
}

\author{
Prepared by \\ Defense Threat Reduction Agency \\ Mercury, Nevada
}

Controlled Copy No.

Revision No.: 0

November 2006

(Republished March 2010) 


\section{CORRECTIVE ACTION DECISION DOCUMENT/CLOSURE REPORT \\ FOR CORRECTIVE ACTION UNIT 559: \\ T-TUNNEL COMPRESSOR/BLOWER PAD, NEVADA TEST SITE, NEVADA}

\footnotetext{
Approved signature

27 Nov 2006

Approved by:

Tiffany A. Lantow

Date:

Environmental Program Manager

Nevada Operations Office

Defense Threat Reduction Agency
} 


\section{Table of Contents}

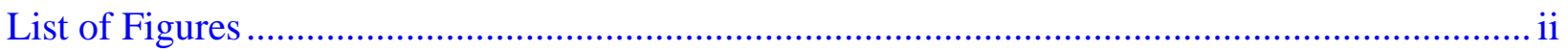

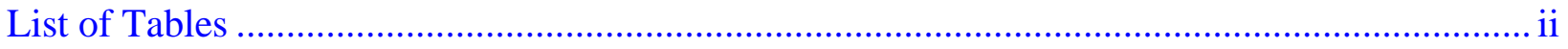

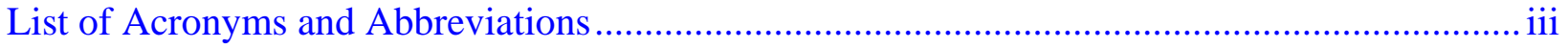

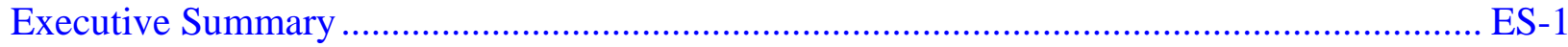

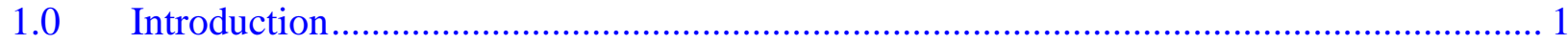

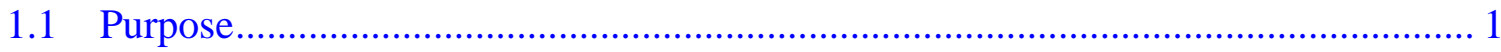

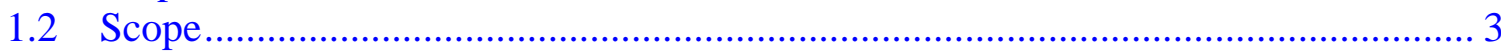

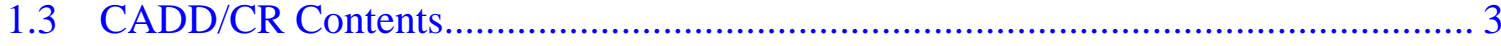

2.0 Corrective Action Investigation Summary ........................................................... 5

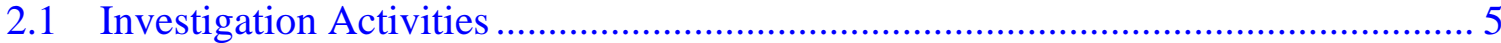

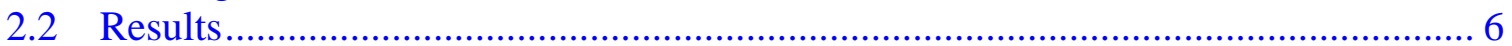

2.2.1 Summary of Analytical Data ............................................................... 6

2.2.1.1 Oil Stained Soil and Concrete (CAS 12-25-13)........................ 7

2.2.1.2 Native Material Under the Pad .................................................. 9

2.2.1.3 T-Tunnel Background ........................................................ 10

2.2.2 Data Assessment Summary............................................................... 11

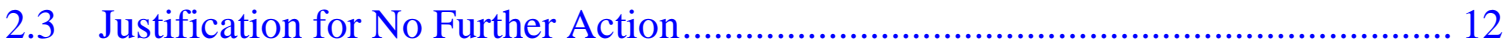

2.3.1 Final Action Levels ........................................................................... 12

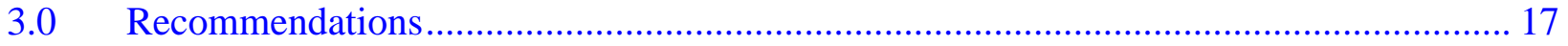

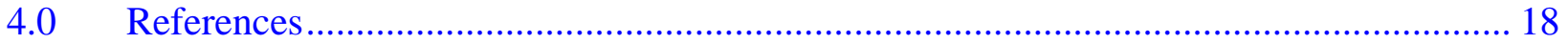

Appendix A - Corrective Action Investigation Report for CAU 559,

T-Tunnel Compressor/Blower Pad, Nevada Test Site

Appendix B - Data Quality Objective Process for CAU 559,

T-Tunnel Compressor/Blower Pad

Appendix C - Data Assessment

Appendix D - Risk Assessment for CAU 559

Attachment A - Derivation of Residual Radioactive Material Guidelines for Radionuclides in Soil at Corrective Action Unit (CAU) 559, T-Tunnel Compressor/Blower Pad, Nevada Test Site, Nevada

Exhibit A - RESRAD Parameters Used for Analysis of CAU 559 Results

Exhibit B - RESRAD Summary Report: CAU 559 Compressor/Blower Pad

Appendix E - Closure Summary 


\section{List of Figures}

Number

Title

Page

$1-1$

CAU 559 Location Map 2

\section{List of Tables}

Number

Title

Page

2-1 Maximum Reported Chemical Values for CAS 12-25-13,

Oil Stained Soil and Concrete..

2-2 Maximum Reported Radiological Values for CAS 12-25-13,

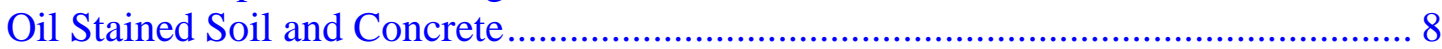

2-3 Maximum Reported Chemical Values for Native Material

Under the Pad...

2-4 Maximum Reported Radiological Values for Native Material

Under the Pad. 10

2-5 Maximum Reported Chemical Values for T-Tunnel Background .......................... 10

2-6 Maximum Reported Radiological Values for T-Tunnel Background ....................... 11

2-7 Tier 2 FALs and CAU 559 Results for Hazardous Constituents of Diesel ............... 15

2-8 Final Action Levels.................................................................................... 16 


\section{List of Acronyms and Abbreviations}

ASTM American Society for Testing and Materials

bgs Below ground surface

BN Bechtel Nevada

CADD Corrective Action Decision Document

CAI Corrective Action Investigation

CAIP Corrective Action Investigation Plan

CAS Corrective Action Site

CAU Corrective Action Unit

CLP Contract Laboratory Program

Co Cobalt

COC Contaminant of concern

COPC Contaminant of potential concern

cps Counts per second

CR Closure Report

Cs $\quad$ Cesium

CSM Conceptual site model

DOE U.S. Department of Energy

DQA Data quality assessment

DQI Data quality indicator

DQO Data quality objective

DRO Diesel-range organics

DTRA Defense Threat Reduction Agency

EESC Environmental Engineering Subcontractor

EPA U.S. Environmental Protection Agency

FAL Final action level 


\section{List of Acronyms and Abbreviations (continued)}

\begin{tabular}{|c|c|}
\hline FFACO & Federal Facility Agreement and Consent Order \\
\hline FSL & Field-screening level \\
\hline $\mathrm{ft}$ & Foot \\
\hline GPS & Global Positioning System \\
\hline GRO & Gasoline-range organics \\
\hline HASL & Health and Safety Laboratory \\
\hline HPGe & High-purity germanium \\
\hline $\mathrm{hrs} / \mathrm{yr}$ & Hours per year \\
\hline ICP & Inductively coupled plasma \\
\hline LUR & Land-use restriction \\
\hline $\mathrm{mg} / \mathrm{kg}$ & Milligrams per kilogram \\
\hline $\mathrm{mrem} / \mathrm{yr}$ & Millirem per year \\
\hline N/A & Not applicable \\
\hline NAC & Nevada Administrative Code \\
\hline NCRP & National Council on Radiation Protection and Measurements \\
\hline ND & Nondetect \\
\hline NDEP & Nevada Division of Environmental Protection and Measurements \\
\hline NNSA/NSO & $\begin{array}{l}\text { U.S. Department of Energy, National Nuclear Security Administration } \\
\text { Nevada Site Office }\end{array}$ \\
\hline NTS & Nevada Test Site \\
\hline PAL & Preliminary action level \\
\hline PCB & Polychlorinated biphenyl \\
\hline $\mathrm{pCi} / \mathrm{g}$ & Picocuries per gram \\
\hline POC & Performance Objective for the Certification of Nonradioactive Hazardous Waste \\
\hline PRG & Preliminary remediation goal \\
\hline $\mathrm{Pu}$ & Plutonium \\
\hline
\end{tabular}




\section{List of Acronyms and Abbreviations (continued)}

\begin{tabular}{|c|c|}
\hline QA & Quality assurance \\
\hline QAPP & Quality Assurance Project Plan \\
\hline QC & Quality control \\
\hline $\mathrm{Ra}$ & Radium \\
\hline RAGS & Risk Assessment Guidance for Superfund \\
\hline RAIS & Risk Assessment Information System \\
\hline RCRA & Resource Conservation and Recovery Act \\
\hline RESRAD & Residual Radioactive \\
\hline RPD & Relative percent difference \\
\hline RT & Regulatory threshold \\
\hline SAPS & Small Area Plastic Scintillation \\
\hline $\mathrm{Sb}$ & Antimony \\
\hline SDG & Sample delivery group \\
\hline SQP & Standard Quality Practice \\
\hline $\mathrm{Sr}$ & Strontium \\
\hline SSTL & Site-specific target level \\
\hline SNJV & Stoller-Navarro Joint Venture \\
\hline SVOC & Semivolatile organic compound \\
\hline TEDE & Total Effective Dose Equivalent \\
\hline Th & Thorium \\
\hline TPH & Total petroleum hydrocarbons \\
\hline UCL & Upper confidence limit \\
\hline VOC & Volatile organic compound \\
\hline$\mu g / k g$ & Micrograms per kilogram \\
\hline$\mu g / L$ & Micrograms per liter \\
\hline$\% \mathrm{R}$ & Percent recovery \\
\hline
\end{tabular}




\section{Executive Summary}

This Corrective Action Decision Document (CADD)/Closure Report (CR) was prepared by the Defense Threat Reduction Agency (DTRA) for Corrective Action Unit (CAU) 559, T-Tunnel Compressor/Blower Pad. This CADD/CR is consistent with the requirements of the Federal Facility Agreement and Consent Order (FFACO) agreed to by the State of Nevada, the U.S. Department of Energy, and the U.S. Department of Defense. Corrective Action Unit 559 is comprised of one Corrective Action Site (CAS):

\section{- 12-25-13, Oil Stained Soil and Concrete}

The purpose of this CADD/CR is to provide justification and documentation supporting the recommendation for closure in place with use restrictions for CAU 559. To support this recommendation, a corrective action investigation (CAI) was performed in July 2005. The purpose of the CAI was to fulfill the following data needs as defined during the Data Quality Objective (DQO) process:

- Determine whether contaminants of concern (COCs) are present.

- If COCs are present, determine their nature and extent.

- Obtain sufficient information to determine appropriate corrective action.

The CAU 559 dataset from the CAI was evaluated based on the data quality indicator parameters. This evaluation demonstrated the quality and acceptability of the dataset for use in fulfilling the DQO data needs (Appendix C of this document).

Analytes detected during the CAI were evaluated against final action levels (FALs) established in this document. Tier 2 FALS were determined for polychlorinated biphenyl (PCB) 1260; the hazardous constituents of total petroleum hydrocarbons (TPH)-diesel-range organics (DRO); and the radionuclides antimony-125, cesium (Cs)-137, cobalt-60, and plutonium-239. Tier 2 FALs were calculated for PCB 1260 and the radionuclides using site-specific information. The hazardous constituents of TPH-DRO were compared to the preliminary action levels (PALs) defined in the Corrective Action Investigation Plan (CAIP), and because none of the PALs were exceeded, the PALs became the FALs. The PCB 1260 FAL was calculated using equations that are compliant with the Risk Assessment Guidance for Superfund (RAGS) Part B procedures and were extracted from the Risk Assessment Information System (RAIS) located online at: http://risk.lsd.ornl.gov/cgi-bin/prg/PRG_search. This website provides an online menu-driven environmental risk assessment system that will calculate preliminary remediation goals based on 
site-specific parameters. The radionuclide FALs were calculated using the Residual Radioactive (RESRAD) code (version 6.21) for the occasional reuse scenario. The RESRAD calculation determined the activities of all radionuclides that together would sum to an exposure dose of 25 millirem per year to a site receptor based on radionuclide relative abundance at the site. Based on the field investigation, none of the contaminants were determined to be present at concentrations exceeding their corresponding FALs. The analytical results for Cs-137 and TPH-DRO were entered into the SW-846 formula to determine whether the site had been characterized to the 90 percent confidence level. For Cs-137, enough samples had been collected; however, for TPH-DRO, it showed that not enough samples were collected so as a conservative approach, TPH-DRO becomes a COC and the site is assumed to be contaminated with TPH-DRO. The sampling was adequate to define the lateral and vertical extent of the TPH-DRO.

Based on the data and risk evaluations, the DQO data needs presented in the CAIP were met, and the data accurately represent the radiological and chemical risk present at CAU 559. Based on the results of the CAI data evaluation, it was determined that closure in place with use restrictions is the appropriate corrective action for CAU 559 and that use restrictions will effectively control exposure to future land users. This is based on the fact that even though the site is assumed to be contaminated with TPH-DRO as described above, this remote, controlled access site poses only limited risk overall to public health and the environment. Therefore, DTRA provides the following recommendations:

- $\quad$ Close TPH-DRO in place at CAU 559 with use restriction.

- $\quad$ No further action for CAU 559.

- A Notice of Completion be issued to DTRA by the Nevada Division of Environmental Protection for closure of CAU 559.

- $\quad$ Move CAU 559 from Appendix III to Appendix IV of the FFACO. 


\section{$1.0 \quad$ Introduction}

This Corrective Action Decision Document (CADD)/Closure Report (CR) has been prepared for Corrective Action Unit (CAU) 559, T-Tunnel Compressor/Blower Pad. The corrective action proposed in this document complies with the Federal Facility Agreement and Consent Order (FFACO) that was agreed to by the State of Nevada, U.S. Department of Energy (DOE), and the U.S. Department of Defense (FFACO, 1996).

The T-Tunnel Compressor/Blower Pad is identified under FFACO classification as CAU 559, T-Tunnel Compressor/Blower Pad. The CAU consists of one Corrective Action Site (CAS): 12-25-13 (Oil Stained Soil and Concrete). The T-Tunnel Compressor/Blower Pad is located approximately 45 miles north of Mercury in Area 12 of the Nevada Test Site (NTS) (Figure 1-1).

This CADD/CR describes the corrective action that is selected as a result of the investigation activities and the rationale for its selection. The rationale consists of a justification for closure in place with use restrictions in accordance with Sections IV.8 and IV.11 of the FFACO (1996).

\section{$1.1 \quad$ Purpose}

The purpose of this CADD/CR is to provide justification for the closure of CAU 559 with use restrictions based on the results of the Corrective Action Investigation (CAI). The CAI was conducted in accordance with the Corrective Action Investigation Plan (CAIP) for Corrective Action Unit 559: T-Tunnel Compressor/Blower Pad, Nevada Test Site (DTRA, 2005), which provides additional information on the history, planning, and scope of the investigation.

The T-Tunnel was used for six nuclear weapons effects tests and two high explosives tests between 1970 and 1997. The Compressor/Blower Pad is where the main components of the ventilation system and the air compressors for T-Tunnel were located. The equipment included air filters, blowers, air compressors, and associated electrical equipment. The Compressor Pad was constructed in the hillside above the tunnel portal. Additional information relating to the site history, planning, and scope of the investigation is presented in the CAIP (DTRA, 2005). 


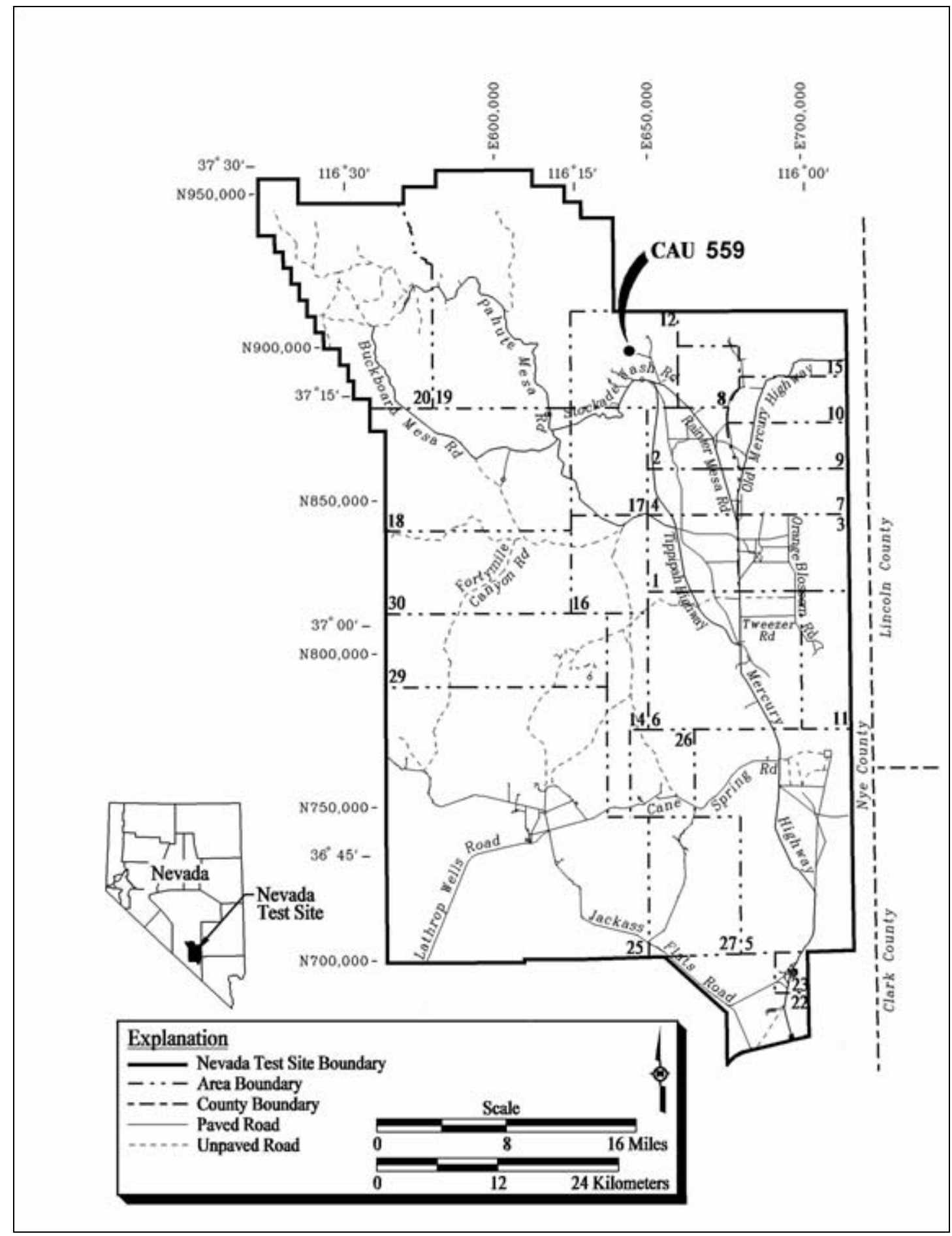

Figure 1-1

CAU 559 Location Map 


\subsection{Scope}

The scope of this CADD/CR is to justify and recommend that closure in place with use restrictions is the appropriate action at CAU 559, T-Tunnel Compressor/Blower Pad. To achieve this scope, the following actions were implemented:

- Evaluation of current site conditions, including the nature and extent of contaminants of concern (COCs).

- Closure in place with use restrictions to prevent exposure of industrial and construction workers to unacceptable risks.

\subsection{CADD/CR Contents}

This CADD/CR is divided into the following sections:

- Section 1.0 - Introduction: Summarizes the purpose, scope, and contents of this $\mathrm{CADD} / \mathrm{CR}$

- Section 2.0 - CAI Summary: Summarizes the investigation field activities, the results of the investigation, and the data quality objective (DQO) assessment.

- Section 3.0 - Recommendation: States why no further action is required.

- Section 4.0 - References: Lists all documents referenced in the CADD/CR.

- Appendix A: Corrective Action Investigation Report for CAU 559, T-Tunnel Compressor/Blower Pad

- Appendix B: Data Quality Objective Process for CAU 559, T-Tunnel Compressor/Blower Pad

- Appendix C: Data Assessment

- Appendix D: Risk Assessment for CAU 559

- Appendix E: Closure Summary

All work was performed in accordance with the following documents:

- Corrective Action Investigation Plan for Corrective Action Unit 559: T-Tunnel Compressor/Blower Pad, Nevada Test Site, Rev. 0 (DTRA, 2005). 
- Industrial Sites Quality Assurance Project Plan (QAPP), Rev. 0 (NNSA/NV, 2002)

- Federal Facility Agreement and Consent Order (FFACO, 1996)

The DQOs identified in the CAIP are as follows:

- Determine whether COCs are present.

- If COCs are present, determine their nature and extent.

- Obtain sufficient information to determine appropriate corrective action.

The data quality indicators (DQIs) as defined in the Industrial Sites QAPP (NNSA/NV, 2002) were achieved and the DQOs established in the CAIP were met.

Subsequent to approval of the CAIP and completion of the CAI, the Nevada Division of Environmental Protection (NDEP) approved a risk-based approach for developing final action levels (FALs) to evaluate contaminant concentrations. That approach was used to evaluate the potential hazards at CAU 559. 


\subsection{Corrective Action Investigation Summary}

The following sections describe and summarize the results of the CAI activities conducted at CAU 559. For detailed CAI results, refer to Appendix A.

\section{$2.1 \quad$ Investigation Activities}

On July 9 and 10, 2005, CAI activities were performed at the T-Tunnel Compressor/Blower Pad as set forth in the CAIP (DTRA, 2005). The purpose of the CAI was to determine whether or not the T-Tunnel Compressor/Blower Pad and/or the underlying native soils contain COCs and, if so, to determine whether they pose an unacceptable risk to human health and/or the environment. As outlined in the CAIP (DTRA, 2005), the following tasks were performed:

- Walkover radiological surveys - Approximately 1 acre was surveyed and more than 2,760 beta/gamma measurements were recorded. The highest beta/gamma measurement detected was 3,339 counts per second (cps). This level is 14.7 times greater than the background radiation emission rate of 227 cps.

- Random soil sampling of the pad and underlying native soils - Soil samples were collected at 11 random locations on the pad. Ten of the locations were sampled using a rotosonic drill rig, and one was sampled using hand tools. At each location that was drilled, two samples were collected, one of the pad material and one of the native material underneath the pad. At the location that was hand sampled, only one sample was collected. A total of 21 samples from the random locations were submitted for volatile organic compounds (VOCs), semivolatile organic compounds (SVOCs), total petroleum hydrocarbons (TPH)-gasoline-range organics (GRO), TPH-diesel-range organics (DRO), polychlorinated biphenyls (PCBs), Resource Conservation and Recovery Act (RCRA) metals, beryllium, gamma spectrometry, isotopic plutonium, and strontium (Sr)-90.

- Biased soil sampling of the access road and pad - Six biased locations were sampled to characterize the access road between the T-Tunnel Muckpile (CAU 476) and the Compressor/Blower Pad. Four of the locations were drilled with the rotosonic drill rig, and two were sampled using hand tools. Two biased locations were sampled to investigate locations with elevated radiological readings on the pad. One was drilled, and one was sampled using hand tools. Eight samples were collected and submitted for VOCs, SVOCs, TPH-GRO, TPH-DRO, PCBs, RCRA metals, beryllium, gamma spectrometry, isotopic plutonium, and Sr-90.

- Background sampling - Three locations were identified and sampled during the T-Tunnel Muckpile CAI, and the results from those samples were used for the background information for this CAI. These samples were only analyzed for RCRA metals and gamma spectrometry. 
The conceptual site model (CSM) postulated that the majority of the pad does not contain contaminants of potential concern (COPCs) (less than 1 percent), and if any COPCs are present, they are probably isolated. The areas most likely to be affected are the areas where petroleum compounds were used for compressor, blower, and electrical equipment maintenance activities, possibly resulting in releases to the surface and shallow subsurface soils. The potential also exists for the presence of radionuclides in the pad as a result of the tunnel exhaust from the tunnel ventilation system that is located on the pad. These releases, if present, were anticipated to have limited lateral and vertical extent. The CSM also stated that it is possible, but unlikely, that the native soil beneath the pad has been impacted by downward migration of COPCs. The results of the CAI showed that there is localized contamination with TPH-DRO, PCBs, and radionuclides in the T-Tunnel Compressor/Blower Pad. The CAI also demonstrated that no contaminants are leaching into the native materials below the pad. Based on these facts, the CSM was shown to be valid.

\section{$2.2 \quad$ Results}

The following is a summary of the data obtained during the CAI.

\subsubsection{Summary of Analytical Data}

The CAI analytical results (Appendix A) indicate the following:

- No VOCs or SVOCs were detected in any of the samples collected during this investigation at concentrations that exceeded the action levels outlined in the CAIP (DTRA, 2005). Some VOCs were detected but they were considered to be laboratory artifacts.

- Total petroleum hydrocarbons-DRO were detected in three random samples and one biased sample from the pad at a concentration (120 to 920 milligrams per kilogram [mg/kg]) that exceeded the action level of $100 \mathrm{mg} / \mathrm{kg}$ (NAC, 2003b). None of the hazardous constituents of TPH-DRO exceeded their Tier 2 action levels; however, because not enough samples were collected to characterize the site to the 90 percent confidence level with respect to TPH-DRO, it is considered to be a COC.

- Polychlorinated biphenyl 1260 was detected at a concentration of $4.4 \mathrm{mg} / \mathrm{kg}$, which exceeds the preliminary action level (PAL) of $0.74 \mathrm{mg} / \mathrm{kg}$ in one biased sample on the pad. It did not exceed the FAL for the remote use scenario of $72.7 \mathrm{mg} / \mathrm{kg}$, so PCB 1260 was determined to not be a COC under the specified reuse scenario.

- Radionuclide results were compared to soil samples taken from undisturbed locations in the western and southwestern United States and to the screening levels of the Nevada Test Site Performance Objective for the Certification of Nonradioactive Hazardous 
Waste (POC) (BN, 1995). Antimony (Sb)-125, cesium (Cs)-137, cobalt (Co)-60, and plutonium (Pu)-239 exceeded their PALs. The FALs were calculated using the Residual Radioactive (RESRAD) code for the remote reuse scenario. None of the radionuclides exceeded their FALs, so none of the radionuclides are COCs.

- There were no chemical or radiological constituents detected in the soil below the Compressor/Blower Pad at concentrations that exceeded the PALs, so the PALs became the FALs for those constituents.

Based on these results, the nature and extent of contamination at CAU 559 has been adequately characterized.

\subsubsection{Oil Stained Soil and Concrete (CAS 12-25-13)}

Except as noted above, none of the chemical constituents were detected above the PALs, so the PALs were identified as the FALs for those constituents. For those constituents that did exceed the PALs, site-specific target levels (SSTLs) for the occasional use scenario were calculated using the occasional use scenario, which then became the FALs for those constituents. The maximum concentration of each detected chemical constituent at this CAS is listed in Table 2-1. A more detailed discussion of the constituents and the determination of the FALs is provided in Appendix D.

Table 2-1

Maximum Reported Chemical Values for CAS 12-25-13, Oil Stained Soil and Concrete

(Page 1 of 2)

\begin{tabular}{|c|c|c|c|c|}
\hline Contaminant & $\begin{array}{c}\text { Result } \\
\mathbf{( m g / k g )}\end{array}$ & Sample No & $\begin{array}{c}\text { Depth } \\
\mathbf{( f t ~ b g s )}\end{array}$ & $\begin{array}{c}\text { Final Action } \\
\text { Level (mg/kg) }\end{array}$ \\
\hline \hline Acetone & 0.016 & $559 \mathrm{BB} 0800.5$ & $0-1$ & $54,000^{\mathrm{a}}$ \\
\hline Arsenic & 6.19 & $559 \mathrm{BH} 0500.5$ & $0-1$ & $23^{\mathrm{b}}$ \\
\hline Barium & 4,350 & $559 \mathrm{BB} 0300.5$ & $0-1$ & $67,000^{\mathrm{a}}$ \\
\hline Beryllium & 0.952 & $559 \mathrm{BH} 0500.5$ & $0-1$ & $1,900^{\mathrm{a}}$ \\
\hline Bis(2-ethylhexyl)phthalate & 1.7 & $559 \mathrm{BB} 0800.5$ & $0-1$ & $120^{\mathrm{a}}$ \\
\hline Cadmium & 5.25 & $559 \mathrm{BH} 0500.5$ & $0-1$ & $450^{\mathrm{a}}$ \\
\hline Chromium & 20.2 & $559 \mathrm{BB} 0800.5$ & $0-1$ & $450^{\mathrm{a}}$ \\
\hline Diesel-Range Organics & $\mathbf{9 2 0}$ & $559 \mathrm{BH} 0200.5$ & $0-1$ & $100^{\mathrm{c}}$ \\
\hline Dimethylphthalate & 0.28 & $559 \mathrm{BB} 0800.5$ & $0-1$ & $100,000^{\mathrm{a}}$ \\
\hline Lead & 129 & $559 \mathrm{BB} 0800.5$ & $0-1$ & $800^{\mathrm{a}}$ \\
\hline Mercury & 0.0905 & $559 \mathrm{BB} 0800.5$ & $0-1$ & $310^{\mathrm{a}}$ \\
\hline
\end{tabular}


Table 2-1

Maximum Reported Chemical Values for CAS 12-25-13, Oil Stained Soil and Concrete

(Page 2 of 2)

\begin{tabular}{|c|c|c|c|c||}
\hline Contaminant & $\begin{array}{c}\text { Result } \\
\mathbf{( m g / k g )}\end{array}$ & Sample No & $\begin{array}{c}\text { Depth } \\
\text { (ft bgs) }\end{array}$ & $\begin{array}{c}\text { Final Action } \\
\text { Level (mg/kg) }\end{array}$ \\
\hline \hline Polychlorinated Biphenyl 1260 & 4.4 & $559 \mathrm{BB} 0700.5 \mathrm{DL}$ & $0-1$ & $72.7^{\mathrm{d}}$ \\
\hline Selenium & 0.579 & $559 \mathrm{BH} 1000.5$ & $0-1$ & $5,100^{\mathrm{a}}$ \\
\hline Silver & 1.45 & $559 \mathrm{BB} 0800.5$ & $0-1$ & $5,100^{\mathrm{a}}$ \\
\hline Trichlorofluoromethane & 0.0024 & $559 \mathrm{BB} 0800.5$ & $0-1$ & $2000^{\mathrm{a}}$ \\
\hline
\end{tabular}

${ }^{\mathrm{a}}$ FAL based on U.S. Environmental Protection Agency Region 9 Preliminary Remediation Goals (PRGs) (EPA, 2004).

${ }^{\mathrm{b}} \mathrm{NTS}$ background plus two standard deviations.

'NAC 445A.2272 (NAC, 2003b)

${ }^{\mathrm{d}}$ Site-specific target level

$\mathrm{ft}$ bgs $=$ Feet below ground surface

$\mathrm{mg} / \mathrm{kg}=$ Milligrams per kilogram

Except as noted above, none of the radionuclides were detected above their PALs, so the PALs were identified as the FALs for those radionuclides. For those radionuclides that did exceed the PALs, SSTLs were calculated using the RESRAD computer code, which then became the FALs for those constituents. The maximum concentration of each detected radionuclide at this CAS is listed in Table 2-2. A more detailed discussion of the radionuclides and the determination of the FALs is provided in Appendix D.

Table 2-2

Maximum Reported Radiological Values for CAS 12-25-13, Oil Stained Soil and Concrete (Page 1 of 2)

\begin{tabular}{||c|c|c|c|c||}
\hline Contaminant & Result (pCi/g) & Sample No & $\begin{array}{c}\text { Depth } \\
\text { (ft bgs) }\end{array}$ & $\begin{array}{c}\text { Final Action } \\
\text { Level (pCi/g) }\end{array}$ \\
\hline \hline Actinium-228 & 2.94 & $559 \mathrm{BH} 0401.0$ & $0.5-1.5$ & $5^{\mathrm{a}}$ \\
\hline Antimony-125 & 22.6 & $559 \mathrm{BB} 0800.5$ & $0-1$ & $136.9^{\mathrm{b}}$ \\
\hline Bismuth-212 & 2.79 & $559 \mathrm{BH} 0600.5$ & $0-1$ & $5^{\mathrm{a}}$ \\
\hline Bismuth-214 & 1.71 & $559 \mathrm{BH} 1000.5$ & $0-1$ & $5^{\mathrm{a}}$ \\
\hline Cobalt-60 & 6.18 & $559 \mathrm{BB} 0800.5$ & $0-1$ & $37.45^{\mathrm{b}}$ \\
\hline Cesium-137 & 1,530 & $559 \mathrm{BB} 0800.5$ & $0-1$ & $9,270^{\mathrm{b}}$ \\
\hline Lead-212 & 3.1 & $559 \mathrm{BH} 0401.0$ & $0.5-1.5$ & $5^{\mathrm{a}}$ \\
\hline Lead-214 & 1.6 & $559 \mathrm{BH} 0900.5$ & $0-1$ & $5^{\mathrm{a}}$ \\
\hline Plutonium-238 & 11.9 & $559 \mathrm{BB} 0800.5$ & $0-1$ & $13^{\mathrm{a}}$ \\
\hline Plutonium-239 & 37.4 & $559 \mathrm{BB} 0800.5$ & $0-1$ & $226.6^{\mathrm{b}}$ \\
\hline
\end{tabular}


Table 2-2

Maximum Reported Radiological Values for CAS 12-25-13, Oil Stained Soil and Concrete

(Page 2 of 2)

\begin{tabular}{|c|c|c|c|c||}
\hline Contaminant & Result (pCi/g) & Sample No & $\begin{array}{c}\text { Depth } \\
\text { (ft bgs) }\end{array}$ & $\begin{array}{c}\text { Final Action } \\
\text { Level (pCi/g) }\end{array}$ \\
\hline \hline Strontium-90 & 207 & $559 \mathrm{BB} 0800.5$ & $0-1$ & $838^{\mathrm{a}}$ \\
\hline Thorium-234 & 3.2 & $559 \mathrm{BH} 0900.5$ & $0-1$ & $105^{\mathrm{a}}$ \\
\hline Thallium-208 & 0.94 & $559 \mathrm{BH} 0200.5$ & $0-1$ & $5^{\mathrm{a}}$ \\
\hline
\end{tabular}

${ }^{\mathrm{a}} \mathrm{FAL}$ based on background or the National Council on Radiation Protection and Measurements Report No. 129 recommended screening limits for construction, commercial, and industrial land-use scenario (NCRP, 1999) scaled from 25- to 15-millirem-peryear dose and the generic guidelines for residual concentration of radionuclides in DOE Order 5400.5 (DOE, 1993).

${ }^{6}$ FAL based on RESRAD calculation for remote use scenario.

$\mathrm{ft}$ bgs $=$ Feet below ground surface

$\mathrm{pCi} / \mathrm{g}=$ Picocuries per gram

\subsubsection{Native Material Under the Pad}

None of the chemical constituents found in the native material under the pad exceeded the PALs as identified in the CAIP (DTRA, 2005), so the PALs are identified as the FALs. The maximum concentration of each detected chemical contaminant found in the native material at this CAS is listed in Table 2-3.

Table 2-3

Maximum Reported Chemical Values for Native Material Under the Pad

\begin{tabular}{|c|c|c|c|c||}
\hline Contaminant & $\begin{array}{c}\text { Result } \\
\mathbf{( m g / k g )}\end{array}$ & Sample No & $\begin{array}{c}\text { Depth } \\
\text { (ft bgs) }\end{array}$ & $\begin{array}{c}\text { Final Action } \\
\text { Level }^{(\mathbf{m g} / \mathbf{k g})^{\mathbf{a}}}\end{array}$ \\
\hline \hline Acetone & 0.0059 & $559 \mathrm{BH} 0706.5$ & $6.0-7.0$ & 54,000 \\
\hline Arsenic & 6.17 & $559 \mathrm{BH} 0706.5$ & $6.0-7.0$ & $23^{\mathrm{b}}$ \\
\hline Barium & 150 & $559 \mathrm{BH} 0805.0$ & $4.5-5.5$ & 67,000 \\
\hline Beryllium & 1.49 & $559 \mathrm{BH} 1005.5$ & $5.0-6.0$ & 1,900 \\
\hline Chromium & 7.42 & $559 \mathrm{BH} 1005.5$ & $5.0-6.0$ & 450 \\
\hline Diesel-Range Organics & 39 & $559 \mathrm{BH} 1105.0$ & $4.5-5.5$ & $100^{\mathrm{c}}$ \\
\hline Lead & 12 & $559 \mathrm{BH} 1005.5$ & $5.0-6.0$ & 800 \\
\hline Mercury & 0.0457 & $559 \mathrm{BH} 1005.5$ & $5.0-6.0$ & 310 \\
\hline Silver & 13 & $559 \mathrm{BH} 0303.5$ & $3.0-4.0$ & 5,100 \\
\hline
\end{tabular}

${ }^{\mathrm{a}}$ FAL based on U.S. Environmental Protection Agency Region 9 Preliminary Remediation Goals (PRGs) (EPA, 2004).

${ }^{\mathrm{b}}$ NTS background plus two standard deviations.

${ }^{\mathrm{c}} \mathrm{NAC}$ 445A.2272 (NAC, 2003b)

$\mathrm{ft}$ bgs $=$ Feet below ground surface $\mathrm{mg} / \mathrm{kg}=$ Milligrams per kilogram 
None of the radionuclides found in the native material under the compressor/blower pad exceeded the PALs as defined in the CAIP (DTRA, 2005), so the PALs for those radionuclides are identified as the FALs. The maximum concentration of each detected radionuclide found in the native material under the pad at this CAS is listed in Table 2-4.

Table 2-4

Maximum Reported Radiological Values for Native Material Under the Pad

\begin{tabular}{|c|c|c|c|c|}
\hline Contaminant & $\begin{array}{c}\text { Result } \\
\text { (pCi/g) }\end{array}$ & Sample No & $\begin{array}{c}\text { Depth } \\
\text { (ft bgs) }\end{array}$ & $\begin{array}{c}\text { Final Action } \\
\text { Level (pCi/g) }^{\mathbf{a}}\end{array}$ \\
\hline \hline Actinium-228 & 4.33 & $559 \mathrm{BH} 0105.5$ & $5.0-6.0$ & 15 \\
\hline Bismuth-214 & 2.71 & $559 \mathrm{BH} 0105.5$ & $5.0-6.0$ & 15 \\
\hline Cesium-137 & 0.6 & $559 \mathrm{BH} 1005.5$ & $5.0-6.0$ & 12.2 \\
\hline Lead-212 & 5.39 & $559 \mathrm{BH} 0105.5$ & $5.0-6.0$ & 15 \\
\hline Lead-214 & 3.3 & $559 \mathrm{BH} 0105.5$ & $5.0-6.0$ & 15 \\
\hline Plutonium-238 & 0.072 & $559 \mathrm{BH} 0706.5$ & $6.0-7.0$ & 13 \\
\hline Plutonium-239 & 0.345 & $559 \mathrm{BH} 0706.5$ & $6.0-7.0$ & 12.7 \\
\hline Thallium-208 & 1.6 & $559 \mathrm{BH} 0105.5$ & $5.0-6.0$ & 15 \\
\hline
\end{tabular}

${ }^{\mathrm{a}} \mathrm{FAL}$ based on background or the National Council on Radiation Protection and Measurements Report No. 129 recommended screening limits for construction, commercial, and industrial land-use scenario (NCRP, 1999) scaled from 25- to 15-millirem-peryear dose and the generic guidelines for residual concentration of radionuclides in DOE Order 5400.5 (DOE, 1993).

$\mathrm{ft}$ bgs = Feet below ground surface

$\mathrm{pCi} / \mathrm{g}=$ Picocuries per gram

\subsubsection{T-Tunnel Background}

Table 2-5 shows the maximum concentration of chemical constituents found in the background samples. Table 2-6 shows the maximum concentration of radionuclides found in the background samples.

Table 2-5

Maximum Reported Chemical Values for T-Tunnel Background (Page 1 of 2)

\begin{tabular}{|c|c|c|c|c||}
\hline Contaminant & $\begin{array}{c}\text { Result } \\
\mathbf{( m g / k g )}\end{array}$ & Sample No & $\begin{array}{c}\text { Depth } \\
\mathbf{( f t ~ b g s )}\end{array}$ & $\begin{array}{c}\text { Final Action } \\
\text { Level } \mathbf{( m g} / \mathbf{k g})^{\mathbf{a}}\end{array}$ \\
\hline \hline Arsenic & 3.8 & TS-B3-01 & $0.5-1.5$ & $23^{\mathrm{b}}$ \\
\hline Barium & 110 & TS-B3-01 & $0.5-1.5$ & 67,000 \\
\hline Cadmium & 0.088 & TS-B3-01 & $0.5-1.5$ & 450 \\
\hline Chromium & 6 & TS-B3-01 & $0.5-1.5$ & 450 \\
\hline Lead & 12 & TS-B2-01 & $0.5-1.5$ & 800 \\
\hline
\end{tabular}


Table 2-5

Maximum Reported Chemical Values for T-Tunnel Background (Page 2 of 2)

\begin{tabular}{|c|c|c|c|c|}
\hline Contaminant & $\begin{array}{c}\text { Result } \\
(\mathrm{mg} / \mathrm{kg})\end{array}$ & Sample No & $\begin{array}{l}\text { Depth } \\
\text { (ft bgs) }\end{array}$ & $\begin{array}{l}\text { Final Action } \\
\text { Level }(\mathrm{mg} / \mathrm{kg})^{\mathrm{a}}\end{array}$ \\
\hline Mercury & 0.0057 & TS-B3-01 & $0.5-1.5$ & 310 \\
\hline
\end{tabular}

${ }^{a}$ FAL based on U.S. Environmental Protection Agency Region 9 Preliminary Remediation Goals (PRGs) (EPA, 2004).

${ }^{\mathrm{b}} \mathrm{NTS}$ background plus two standard deviations.

$\mathrm{ft}$ bgs $=$ Feet below ground surface

$\mathrm{pCi} / \mathrm{g}=$ Picocuries per gram

Table 2-6

Maximum Reported Radiological Values for T-Tunnel Background

\begin{tabular}{|c|c|c|c|c|}
\hline Contaminant & $\begin{array}{c}\text { Result } \\
\mathbf{( p C i / g )}\end{array}$ & Sample No & $\begin{array}{c}\text { Depth } \\
\mathbf{( f t ~ b g s )}\end{array}$ & $\begin{array}{c}\text { Final Action } \\
\text { Level (pCi/g) }\end{array}$ \\
\hline \hline Actinium-228 & 3.2 & TS-B2-01 & $0.5-1.5$ & 15 \\
\hline Americium-241 & 2.8 & TS-B2-01 & $0.5-1.5$ & 12.7 \\
\hline Bismuth-212 & 3.6 & TS-B1-01 & $0.5-1.5$ & 15 \\
\hline Bismuth-214 & 2.4 & TS-B2-01 & $0.5-1.5$ & 15 \\
\hline Cesium-137 & 13.5 & TS-B2-01 & $0.5-1.5$ & $9,270^{\mathrm{b}}$ \\
\hline Lead-212 & 2.76 & TS-B3-01 & $0.5-1.5$ & 15 \\
\hline Lead-214 & 1.59 & TS-B1-01 & $0.5-1.5$ & 15 \\
\hline Plutonium-238 & 1.03 & TS-B2-01 & $0.5-1.5$ & 13 \\
\hline Plutonium-239 & 9.6 & TS-B2-01 & $0.5-1.5$ & $226.6^{\mathrm{b}}$ \\
\hline Strontium-90 & 1.13 & TS-B2-01 & $0.5-1.5$ & 838 \\
\hline Thallium-208 & 0.88 & TS-B1-01 & $0.5-1.5$ & 15 \\
\hline \hline
\end{tabular}

${ }^{\mathrm{a}} \mathrm{FAL}$ based on background or the National Council on Radiation Protection and Measurements Report No. 129 recommended screening limits for construction, commercial, and industrial land-use scenario (NCRP, 1999) scaled from 25- to 15-millirem-per-year dose and the generic guidelines for residual concentration of radionuclides in DOE Order 5400.5 (DOE, 1993).

${ }^{\mathrm{b}} \mathrm{FAL}$ based on RESRAD calculation for remote use scenario.

$\mathrm{ft}$ bgs = Feet below ground surface

$\mathrm{pCi} / \mathrm{g}=$ Picocuries per gram

\subsubsection{Data Assessment Summary}

The data quality assessment (DQA) is presented in Appendix $\mathrm{C}$ and includes an evaluation of the DQIs to determine the degree of acceptability and usability of the reported data in the decision-making process. The DQO process ensures that the right type, quality, and quantity of data are available to support the resolution of those decisions at an appropriate level of 
confidence. Using both the DQO and DQA processes helps ensure that DQO decisions are sound and defensible.

The DQA process as presented in Appendix C is comprised of the following steps:

- Step 1 - Review DQOs and Sampling Design.

- Step 2 - Conduct a Preliminary Data Review.

- Step 3 - Select the Test.

- $\quad$ Step 4 - Verify the Assumptions.

- Step 5 - Draw Conclusions from the Data.

Sample locations that support the presence and/or extent of contamination at CAU 559 are shown in Appendix A. Based on the results of the DQA presented in Appendix C, the DQO requirements have been met, and the close in place with use restrictions corrective action alternative was selected as the closure alternative at CAU 559 (T-Tunnel Compressor/Blower Pad). The DQA also determined that information generated during the investigation supports the CSM assumptions, and the data collected support the intended use in the decision-making process.

\subsection{Justification for No Further Action}

Use restrictions with no further corrective action is justified based on an evaluation of risk (see Appendix D) to ensure protection of the public and the environment in accordance with Nevada Administrative Code (NAC) 445A (NAC, 2003a), feasibility, and cost effectiveness. The corrective action was determined from DQO decision statements based on a comparison of the analyte concentrations detected in CAI soil samples to the FALs defined in Section 2.3.1. Because the extent of the COCs is limited and the CAI demonstrated that there is no vertical migration through the Compressor/Blower Pad into the native material below, the corrective action to close in place with administrative controls is justified at CAU 559. Appendix D presents an evaluation of risk associated with the recommended closure alternative.

\subsubsection{Final Action Levels}

The CAU 559 FALs are risk-based cleanup goals that, if met, will ensure that each release site will not pose an unacceptable risk to human health or the environment under the occasional use exposure scenario, and that the conditions at each site are in compliance with all applicable laws and regulations. The process described in this section to define and determine the FALs conforms to NAC Section 445A.2272 (NAC, 2003b), which lists the requirements for sites with soil contamination. For the evaluation of corrective actions, NAC Section 445A.22705 
(NAC, 2003c) recommends the use of American Society for Testing and Materials (ASTM) Method E 1739-95 to “conduct an evaluation of the site, based on the risk it poses to public health and the environment, to determine the necessary remediation standards (i.e., FALs) or to establish that corrective action is not necessary."

The ASTM procedure (ASTM, 1995) defines three tiers (or levels) of evaluation involving increasingly sophisticated analyses as follows.

Tier 1 Evaluation - Sample results from source areas (highest concentrations) are compared to action levels based on generic (non-site-specific) conditions (i.e., the PALs established in the CAIP). The FALs may then be established as the Tier 1 action levels, or the FALs may be calculated using a Tier 2 evaluation.

Tier 2 Evaluation - Conducted by calculating Tier 2 SSTLs using site-specific information as inputs to the same or similar methodology used to calculate Tier 1 action levels. The Tier 2 SSTLs are then compared to individual sample results from reasonable points of exposure (as opposed to the source areas as is done in Tier 1) on a point-by-point basis. Total TPH concentrations are not used for risk-based decisions under Tier 2 or Tier 3. Rather, the individual hazardous constituents in TPH are compared to their SSTLs.

Alternatively, the Tier 2 risk-based corrective action process SSTLs may be compared to the predicted concentration or activity of the contaminant at the point of exposure based on attenuation from the source using relatively simplistic mathematical models. Points of exposure are defined as those locations at which an individual or population may come in contact with a COC originating from a CAS. If a Tier 2 evaluation is conducted, the calculations used to derive the SSTLs and the contaminant attenuation calculations will be provided as an appendix to the investigation report. If remediation to Tier 2 SSTLs is not practical, a Tier 3 evaluation may be conducted.

Tier 3 Evaluation - A Tier 3 evaluation is conducted by calculating SSTLs on the basis of more sophisticated risk analyses using methodologies described in ASTM Method E 1739-95 that consider site-, pathway-, and receptor-specific parameters. Tier 3 evaluation is much more complex than Tiers 1 and 2, because it may include additional site characterization, probabilistic evaluations, and sophisticated chemical fate/transport models. The Tier 3 SSTLs are then compared to the upper 95 percent confidence limit of the mean of sample results from reasonable points of exposure (as opposed to individual sample results as is done in Tier 2). Contaminant concentrations exceeding Tier 3 SSTLs require corrective action. If a Tier 3 evaluation is 
conducted, the calculations used to derive the SSTLs and the upper confidence limit of the means will be provided as an appendix to the investigation report.

A Tier 1 evaluation was conducted for all COPCs to determine whether contaminant levels satisfy the criteria for regulatory closure or warrant a more site-specific assessment. This was accomplished by comparing individual source area contaminant concentration results to the Tier 1 actions levels (the PALs established in the CAIP). The Tier 1 PALs were for the industrial use scenario.

The constituents detected at CAU 559 that exceeded Tier 1 action levels were:

- TPH-DRO

- $\quad$ PCB 1260

- Co-60

- Cs-137

- $\mathrm{Pu}-239$

- $\mathrm{Sb}-125$

The concentration of all constituents not listed above, were below Tier 1 action levels and the corresponding PALs were established as the Tier 1 FALs. The constituents that exceeded Tier 1 action levels were moved to a Tier 2 evaluation.

The Tier 2 evaluation of TPH-DRO compared the concentrations of the individual hazardous constituents of TPH-DRO to the Tier 1 action levels in the sample that exceeded for TPH-DRO. No hazardous constituents were found in the samples and therefore did not exceed Tier 1 action levels, so site-specific action levels were not calculated. The PALs were established as the FALs for the hazardous constituents in TPH-DRO at CAU 559. The FALs are presented in Table 2-7. Additional details of the Tier 2 evaluation are provided in Appendix D. 
Table 2-7

Tier 2 FALs and CAU 559 Results for Hazardous Constituents of Diesel

\begin{tabular}{|c|c|c|c||}
\hline \multirow{2}{*}{ CAS Number } & Common Name & $\begin{array}{c}\text { Final Action Level } \\
\text { (mg/kg) }\end{array}$ & $\begin{array}{c}\text { Maximum Reported } \\
\text { Value (mg/kg) }\end{array}$ \\
\cline { 3 - 4 } & & 70 & $12-25-13$ \\
\hline $108-67-8$ & $1,3,5-T r i m e t h y l b e n z e n e$ & 190 & ND \\
\hline $91-57-6$ & 2-Methylnaphthalene & 2.1 & ND \\
\hline $56-55-3$ & Benzo(a)anthracene & 1.4 & ND \\
\hline $71-43-2$ & Benzene & 0.21 & ND \\
\hline $50-32-8$ & Benzo(a)pyrene & 400 & ND \\
\hline $100-41-4$ & Ethylbenzene & 190 & ND \\
\hline $91-20-3$ & Naphthalene & 520 & ND \\
\hline $108-88-3$ & Toluene & 420 & ND \\
\hline $1330-20-7$ & Total Xylene & 240 & ND \\
\hline $104-51-8$ & N-Butylbenzene & 240 & ND \\
\hline $103-65-1$ & N-Propylbenzene & & \\
\hline
\end{tabular}

CAS $=$ Chemical Abstracts Service $\mathrm{mg} / \mathrm{kg}=$ Milligrams per kilogram $\mathrm{ND}=$ Nondetect

None of the chemical constituents exceeded the PALs, so a Tier 2 evaluation was not conducted. The PALs were established as the FALs for the chemical constituents.

The Tier 2 evaluation for the radionuclides was conducted by entering site-specific radionuclide information and physical characteristics of the site into the RESRAD program to calculate the site-specific action levels. This calculated the site-specific activities needed to sum to an exposure dose of 25 millirem per year (mrem/yr) to a site receptor. These calculated concentrations were established as the FALs for each radionuclide at the CAS that exceeded a Tier 1 action level. The Tier 2 calculated FALs are presented in Table 2-8. Additional details of the Tier 2 evaluation are provided in Appendix D. 
Table 2-8

Final Action Levels

\begin{tabular}{|c|c|c|c|}
\hline COPCs & Tier 1 FALs & Tier 2 FALs & $\begin{array}{l}\text { Tier } 3 \\
\text { FALs }\end{array}$ \\
\hline VOCs & PALs & $\mathrm{N} / \mathrm{A}$ & N/A \\
\hline SVOCs & $\begin{array}{l}\text { PALs except } \\
\text { for PCB } 1260\end{array}$ & PCB $1260-72.7 \mathrm{mg} / \mathrm{kg}$ & $\mathrm{N} / \mathrm{A}$ \\
\hline RCRA metals & PALs & $\mathrm{N} / \mathrm{A}$ & $\mathrm{N} / \mathrm{A}$ \\
\hline TPH-DRO & PALS & TPH-DRO hazardous constituent PALs & N/A \\
\hline Radionuclides & $\begin{array}{l}\text { PALs except as } \\
\text { listed under Tier } 2\end{array}$ & $\begin{array}{c}\text { CAS 12-25-13 } \\
\text { Co-60 3.7E+01 pCi/g, Cs-137 9.3E+03 pCi/g, } \\
\text { Pu-239 2.3E+02 pCi/g, Sb-125 1.4E+02 pCi/g }\end{array}$ & $\mathrm{N} / \mathrm{A}$ \\
\hline
\end{tabular}

Co $=$ Cobalt

$\mathrm{COPC}=$ Contaminant of potential concern

$\mathrm{Cs}=$ Cesium

DRO = Diesel-range organics

$\mathrm{FAL}=$ Final action level

$\mathrm{mg} / \mathrm{kg}=$ Milligrams per kilogram

N/A = Not applicable

$\mathrm{PAL}=$ Preliminary action level
$\mathrm{PCB}=$ Polychlorinated biphenyl

$\mathrm{pCi} / \mathrm{g}=$ Picocuries per gram

$\mathrm{Pu}=$ Plutonium

$\mathrm{Sb}=$ Antimony

RCRA = Resource Conservation and Recovery Act

SVOC $=$ Semivolatile organic compound

$\mathrm{TPH}=$ Total petroleum hydrocarbons

VOC $=$ Volatile organic compound 


\subsection{Recommendations}

The data generated by the CAI show that the FALs were not exceeded at CAU 559, T-Tunnel Compressor/Blower Pad. Although the FALs were not exceeded at CAU 559, not enough samples were collected to reach the 90 percent confidence level that the site was characterized with respect to TPH-DRO so, as a conservative approach, closure in place with use restrictions is considered the best option for closing this site. This recommendation is based on the fact that the site is considered to be contaminated with TPH-DRO. The future use of CAU 559 will be restricted from any activity unless concurrence is obtained from NDEP. The use restriction will prevent inadvertent contact with the COCs, and meets all applicable state and federal regulations for closure of the site.

In conclusion, DTRA requests that NDEP issue a Notice of Completion for this CAU and approval to move the CAU from Appendix III to Appendix IV of the FFACO. 


\subsection{References}

ASTM, see American Society for Testing and Materials.

American Society for Testing and Materials. 1995. Standard Guide for Risk-Based Corrective Action Applied at Petroleum Release Sites, ASTM E 1739-95 (Reapproved 2002). Philadelphia, PA.

BN, see Bechtel Nevada.

Bechtel Nevada. 1995. Nevada Test Site Performance Objective for Certification of Nonradioactive Hazardous Waste, Rev. 0, G-E11/96.01. Las Vegas, NV.

DOE, see U.S. Department of Energy.

DOE/NV, see U.S. Department of Energy, Nevada Operations Office.

DTRA, see Defense Threat Reduction Agency.

Defense Threat Reduction Agency. 2005. Corrective Action Investigation Plan for Corrective Action Unit 559: T-Tunnel Compressor/Blower Pad, Nevada Test Site, Rev. 0. Las Vegas, NV.

EPA, see U.S. Environmental Protection Agency.

FFACO, see Federal Facility Agreement and Consent Order.

Federal Facility Agreement and Consent Order. 1996 (as amended). Agreed to by the State of Nevada, the U.S. Department of Energy, and the U.S. Department of Defense.

NAC, see Nevada Administrative Code.

NCRP, see National Council on Radiation Protection and Measurements.

NNSA/NV, see U.S. Department of Energy, National Nuclear Security Administration Nevada Operations Office.

National Council on Radiation Protection and Measurements. 1999. Recommended Screening Limits for Contaminated Surface Soil and Review of Factors Relevant to Site-Specific Studies. NCRP Report No. 129. Bethesda, MD

Nevada Administrative Code. 2003a. NAC 445A, “Water Controls.” Carson City, NV.

Nevada Administrative Code. 2003b. NAC 445A.2272, “Contamination of Soil: Establishment of Action Levels.” Carson City, NV. 
Nevada Administrative Code. 2003c. NAC 445A.22705, “Contamination of Soil: Evaluation of Site by Owner or Operator; Review of Evaluation by Division.” Carson City, NV.

U.S. Department of Energy. 1993. "Radiation Protection of the Public and the Environment." DOE Order 5400.5, Change 2. Washington, DC.

U.S. Department of Energy, National Nuclear Security Administration Nevada Operations Office. 2002. Industrial Sites Quality Assurance Project Plan, Nevada Test Site, Nevada, DOE/NV--372, Rev. 3. Las Vegas, NV.

U.S. Environmental Protection Agency. 2004. Region 9 Preliminary Remediation Goals (PRGs). San Francisco, CA. 


\section{Appendix A}

Corrective Action Investigation Report for CAU 559,

T-Tunnel Compressor/Blower Pad, Nevada Test Site 


\section{Table of Contents}

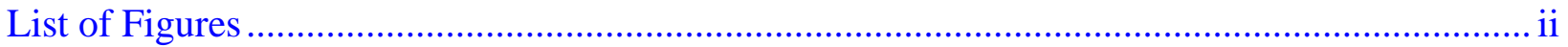

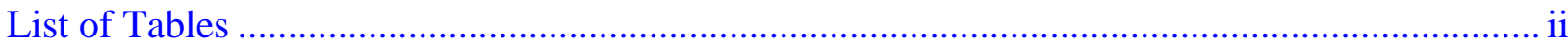

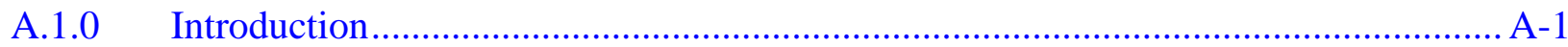

A.1.1 Project Objective ..................................................................... A-1

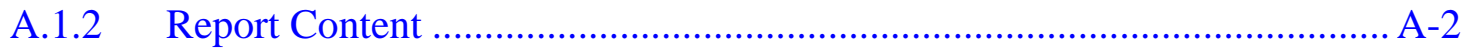

A.2.0 Field Investigation and Sampling Activities...................................................... A-3

A.2.1 Surface Radiological Surveys …...................................................... A-3

A.2.2 Borehole Locations............................................................................... A-4

A.2.3 Subsurface Characterization ............................................................... A-5

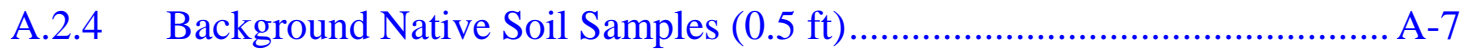

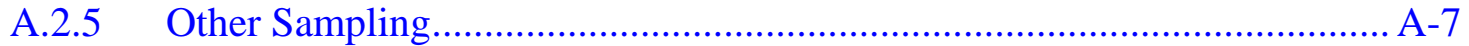

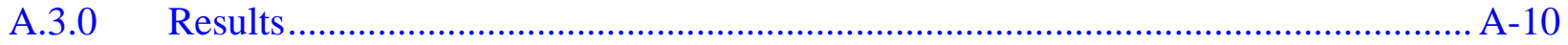

A.3.1 Total Volatile Organic Compounds and Total Semivolatile

Organic Compounds ..................................................................... A-10

A.3.2 Polychlorinated Biphenyls ........................................................ A-10

A.3.3 Total Petroleum Hydrocarbons ........................................................ A-10

A.3.3 Total RCRA Metals Results ........................................................... A-13

A.3.4 Gamma Spectroscopy Results ......................................................... A-14

A.4.0 Quality Assurance ........................................................................................ A -17

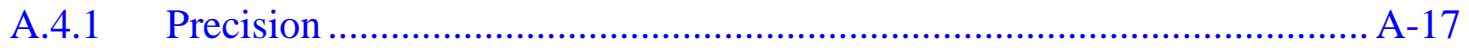

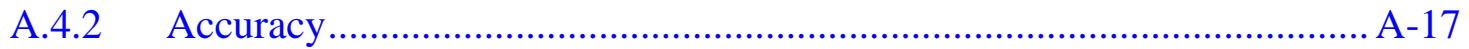

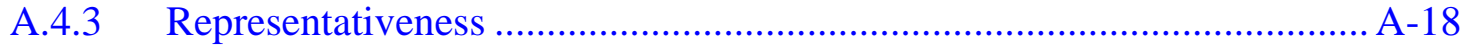

A.4.4 Completeness.............................................................................. A-18

A.4.5 Comparability ........................................................................... A-18

A.4.6 Data Validation......................................................................... A-19

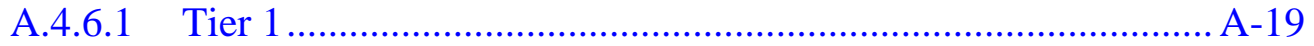

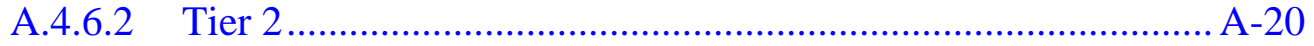

A.4.6.3 Tier 3 .................................................................... A-20

A.4.7 Quality Control Samples ............................................................ A-20

A.4.7.1 Field Quality Control Samples............................................... A-21

A.4.7.2 Laboratory Quality Control Samples ....................................... A-22

A.4.8 Nonconformances and Field Deficiencies........................................... A-23

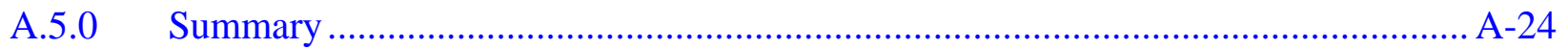

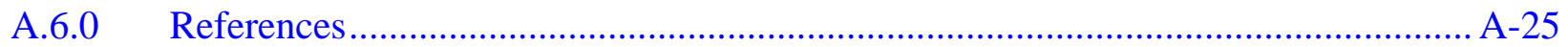




\section{List of Figures}

Number

Title

Page

A.2-1 CAU 559 Radiological Walkover Survey Results............................................... A-4

A.2-2 CAU 559 Actual Borehole and Sample Locations ................................................. A-6

A.2-3 CAU 476 Background Sample Locations .............................................................. A-8

\section{List of Tables}

A.2-1 Borehole Locations, Total Depth, and Sampling Depths ............................... A-5

A.2-2 CAU 559 Actual Borehole and Sample Locations ......................................... A-9

A.3-1 Samples Collected and Submitted for Laboratory Analyses for the CAU 559 T-Tunnel Compressor/Blower Pad Corrective Action Investigation.

A.3-2 Chemical Analytical Methods Used for the T-Tunnel Compressor/Blower Pad Investigation Samples

A.3-3 VOCs, SVOCs, and Total Metals Detects for the CAU 559 T-Tunnel Compressor/Blower Pad Investigation

A.3-4 Radionuclide Detects for the CAU 559 T-Tunnel

Compressor/Blower Pad Investigation A-16 


\section{A.1.0 Introduction}

This report presents a summary of the field activities and the data collected during the CAI of the T-Tunnel Compressor/Blower Pad. The CAI was controlled and guided by the Corrective Action Investigation Plan for Corrective Action Unit 559: T-Tunnel Compressor/Blower Pad, Nevada Test Site, Rev. 0 (DTRA, 2005). The T-Tunnel Compressor/Blower Pad is identified in the FFACO as Corrective Action Unit (CAU) 559, Corrective Action Site (CAS) 12-25-13 (FFACO, 1996).

The T-Tunnel Compressor/Blower Pad is located approximately 45 miles north of Mercury in Area 12 of the NTS (see Figure 1-1). The T-Tunnel was used for six nuclear weapons effects tests tests between 1970 and 1987. The Compressor/Blower Pad is where the main components of the ventilation system and the air compressors for T-Tunnel were located. The equipment included air filters, blowers, air compressors, and associated electrical equipment. The Compressor Pad was constructed in the hillside above the tunnel portal. Additional information relating to the site history, planning, and scope of the investigation is presented in the CAIP (DTRA, 2005).

\section{A.1.1 Project Objective}

The primary objective of the CAI was to determine whether or not COPCs are present in the T-Tunnel Compressor/Blower Pad and/or the underlying native soils. The data collected during the field effort will enable DTRA to make informed decisions about the future operation, use, or closure of the Compressor/Blower Pad. The following tasks were performed to meet the project objective:

- Walkover radiological survey.

- Collection of random and biased soil samples.

- Field screening for VOCs and radioactivity for health and safety purposes and to optimize the locations for optional environmental samples.

- Collect environmental and QC samples and send them to an off-site laboratory for analysis.

- Samples were analyzed for VOCs, SVOCs, total RCRA metals, and radionuclides. 
- All of the soil and rock samples were described to assess soil and waste physical characteristics.

\section{A.1.2 Report Content}

The CAI report is intended to provide information and data in sufficient detail to support the selection of a preferred corrective action alternative. The contents of this CAI report are as follows:

- Section A.1.0 of this report is the introduction which presents the objective of the project.

- Section A.2.0 details the investigation and provides a description of the sample collection activities and locations.

- $\quad$ Section A.3.0 is a summary of the sample analytical results.

- Section A.4.0 discusses the quality assurance (QA) and quality control (QC) procedures that were followed and the results of the QA and QC activities.

- Section A.5.0 summarizes the significant results of the CAI.

- $\quad$ Section A.6.0 lists the references cited.

To provide a concise summary, the complete field documentation and laboratory data is not contained in this report. These documents are retained in the project files. 


\section{A.2.0 Field Investigation and Sampling Activities}

The field investigation and sampling program were managed in accordance with the requirements set forth in the CAIP (DTRA, 2005). The field activities were performed in accordance with an approved site-specific health and safety plan (SSHASP) (SNJV, 2005). The samples were collected and documented by following approved sampling, field activity and sample collection documentation, decontamination, chain-of-custody, shipping, and radiation screening protocols and procedures. Quality control samples (e.g., equipment rinsate blanks, trip blanks, and sample duplicates) were collected as required by the CAIP and in accordance with approved procedures.

\section{A.2.1 Surface Radiological Surveys}

The walkover radiological survey was completed in June 2005. Results from the walkover survey are shown in Figure A.2-1.

The walkover radiological survey was conducted by walking over the pad and access road carrying a Small Area Plastic Scintillation (SAPS) Detector Model 8204, with a TSA Model SC-755 Controller, and a Trimble Pathfinder Pro XRSTM GPS receiver with a TSC1TM data logger. Each radiological measurement was taken with the SAPS detector and recorded on the TSC1 data logger and stored with its related GPS measurement in a combined file. Approximately 1 acre was surveyed and more than 2,760 beta/gamma measurements were recorded (Figure A.2-1). The highest beta/gamma measurement detected was 3,339 counts per second (cps) at Nevada State Plane coordinates E 645455.0, N 897925.7. This level is 14.7 times greater than the background radiation emission rate of $227 \mathrm{cps}$. 


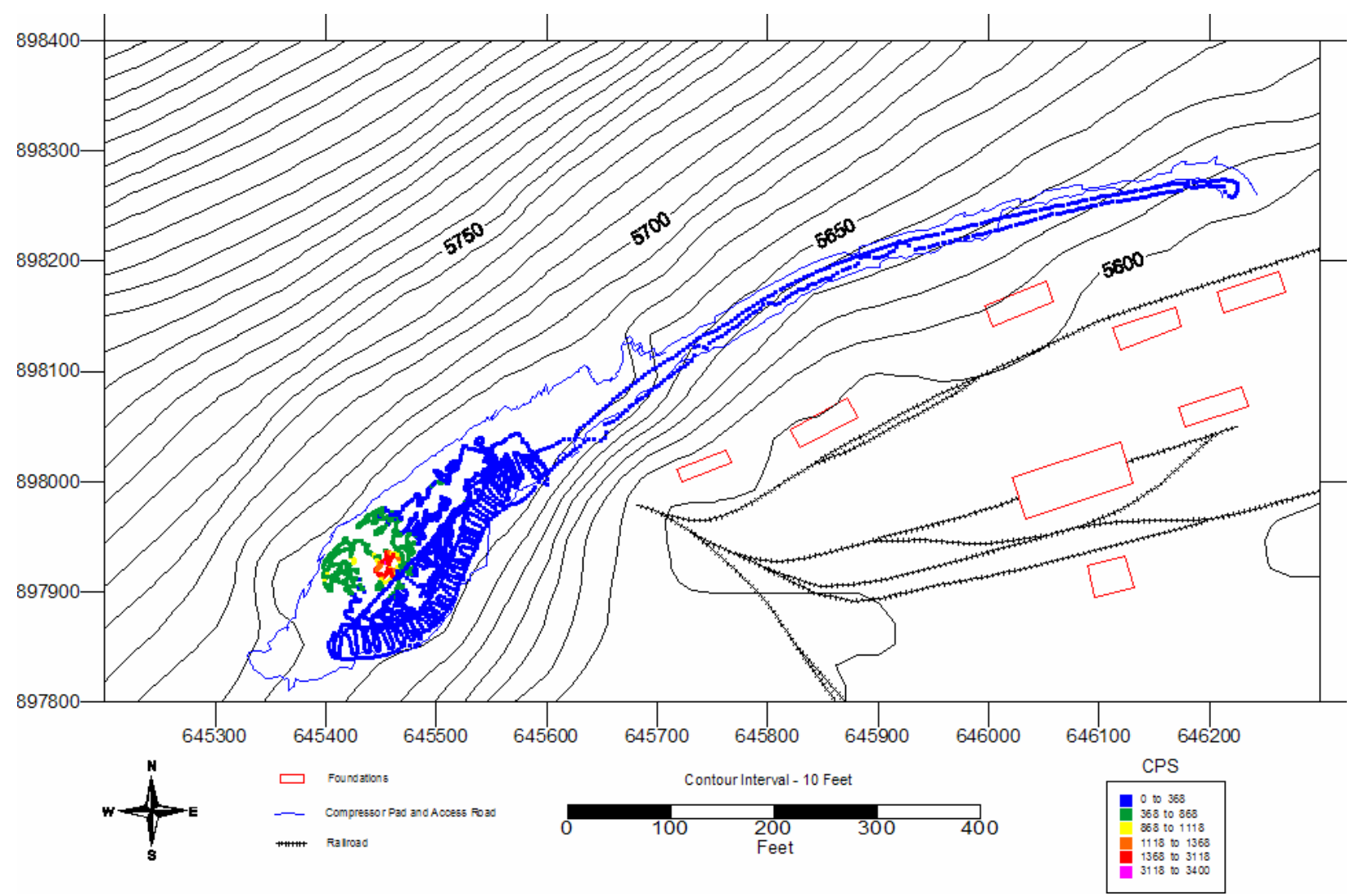

Figure A.2-1

CAU 559 Radiological Walkover Survey Results

\section{A.2.2 Borehole Locations}

Before commencing the drilling operations, environmental scientists used a Trimble Global Positioning System (GPS) total station surveying instrument to locate and mark each proposed sample location. The random sample locations at CAU 559 were identified using a simple random sampling strategy as defined in Gilbert (1987). The CAIP listed six biased sampling locations based on process knowledge, and two additional biased locations were identified in the field to provide additional information. After drilling operations were completed, all sampling locations were surveyed using a GPS to record the as-built locations. The borehole locations are provided in Table A.2-1. 
Table A.2-1

Borehole Locations, Total Depth, and Sampling Depths

\begin{tabular}{|c|c|c|c|c|c|c|c|}
\hline Hole No. & Northing & Easting & $\begin{array}{l}\text { Elevation } \\
\text { (feet) }\end{array}$ & $\begin{array}{l}\text { Sampling } \\
\text { Method }\end{array}$ & $\begin{array}{l}\text { Total } \\
\text { Depth } \\
\text { (feet) }\end{array}$ & $\begin{array}{l}\text { Sample } \\
\text { Depth } \\
\text { (feet) }\end{array}$ & $\begin{array}{c}\text { No. of } \\
\text { Samples }\end{array}$ \\
\hline \multicolumn{8}{|c|}{ Random Locations } \\
\hline TBH01 & 898076.1 & 645688.8 & $5,649.6$ & drill & 6.0 & $0.5,5.5$ & 2 \\
\hline TBH02 & 898042.8 & 645591.6 & $5,651.9$ & drill & 4.0 & $0.5,3.5$ & 2 \\
\hline TBH03 & 897970.5 & 645541.1 & $5,653.1$ & drill & 4.0 & $0.5,3.5$ & 2 \\
\hline TBH04 & 897978.1 & 645498.1 & $5,653.6$ & drill & 6.0 & $1.0,5.5$ & 2 \\
\hline TBH05 & 897999.8 & 645527.9 & $5,652.7$ & drill & 9.0 & $0.5,6.0$ & 2 \\
\hline TBH06 & 897867.4 & 645495.2 & $5,654.9$ & drill & 4.5 & $0.5,4.0$ & 2 \\
\hline TBH07 & 897848.5 & 645453.3 & $5,657.8$ & drill & 7.0 & $1.0,6.5$ & 2 \\
\hline TBH08 & 897843.1 & 645421.6 & $5,660.1$ & drill & 5.5 & $0.5,5.0$ & 2 \\
\hline TBH09 & 898066.1 & 645644.6 & $5,650.6$ & hand & 0.5 & 0.5 & 1 \\
\hline TBH10 & 897910.6 & 645511.3 & $5,654.0$ & drill & 6.0 & $0.5,5.5$ & 2 \\
\hline \multirow[t]{2}{*}{ TBH11 } & 897943.6 & 645512.1 & $5,653.5$ & drill & 6.0 & $0.5,5.0$ & 2 \\
\hline & & & & Total & 58.5 & & 21 \\
\hline \multicolumn{8}{|c|}{ Biased Locations } \\
\hline TBB01 & 898135.0 & 645785.2 & $5,643.3$ & drill & 3.5 & 0.5 & 1 \\
\hline TBB02 & 898175.0 & 645865.5 & $5,639.3$ & drill & 5.0 & 0.5 & 1 \\
\hline TBB03 & 898214.4 & 645953.1 & $5,634.0$ & drill & 3.0 & 0.5 & 1 \\
\hline TBB04 & 898249.5 & 646051.8 & $5,625.1$ & hand & 0.5 & 0.5 & 1 \\
\hline TBB05 & 898269.6 & 646142.2 & $5,614.0$ & hand & 0.5 & 0.5 & 1 \\
\hline TBB06 & 898274.8 & 646218.6 & $5,605.5$ & drill & 4.5 & 0.5 & 1 \\
\hline TBB07 & 897892.3 & 645449.6 & $5,656.1$ & drill & 5.0 & 0.5 & 1 \\
\hline \multirow[t]{2}{*}{ TBB08 } & 897929.6 & 645481.4 & $5,654.1$ & hand & 0.5 & 0.5 & 1 \\
\hline & & & & Total & 22.5 & & 8 \\
\hline \multicolumn{8}{|c|}{ Background Locations (CAU 476) } \\
\hline TS-B1 & 898507.1 & 645735.7 & $5,790.9$ & hand & 1.0 & 0.5 & 1 \\
\hline TS-B2 & 897306.0 & 646482.4 & $5,613.5$ & hand & 1.0 & 0.5 & 1 \\
\hline \multirow[t]{2}{*}{ TS-B3 } & 897517.7 & 644915.6 & $5,720.0$ & hand & 1.0 & 0.5 & 1 \\
\hline & & & & Total & 3.0 & & 3 \\
\hline
\end{tabular}

\section{A.2.3 Subsurface Characterization}

The subsurface characterization was conducted on July 9 and 10, 2005. Soil sampling was accomplished by either drilling or hand sampling. The rotary sonic (rotosonic) drilling method was used to produce continuous soil cores for sampling of the subsurface soil. The holes were drilled through the pad and into the native material under the pad. If the native material was alluvial in nature, the borehole was advanced $5.0 \mathrm{ft}$ into the native material or until refusal. If the 
native material was bedrock, the borehole was only advanced $2.0 \mathrm{ft}$ into the native material or until refusal. Copies of the soil boring logs for all boreholes are in Attachment A. The boreholes were drilled to depths ranging from 3.0 to $9.0 \mathrm{ft}$. Hand sampling consisted of using hand tools to collect a sample from a depth of $0.5 \mathrm{ft}$ or until refusal. A total of $81 \mathrm{ft}$ of drilling was completed in 15 boreholes and four hand sampled locations. Samples were collected to characterize the pad and/or the native material under the pad and the access road. Four locations were not accessible to the drill rig so were sampled by hand. The random locations were designated as TBH01 through TBH11, and the biased locations were designated TBB01 through TBB08 (Figure A.2-2).

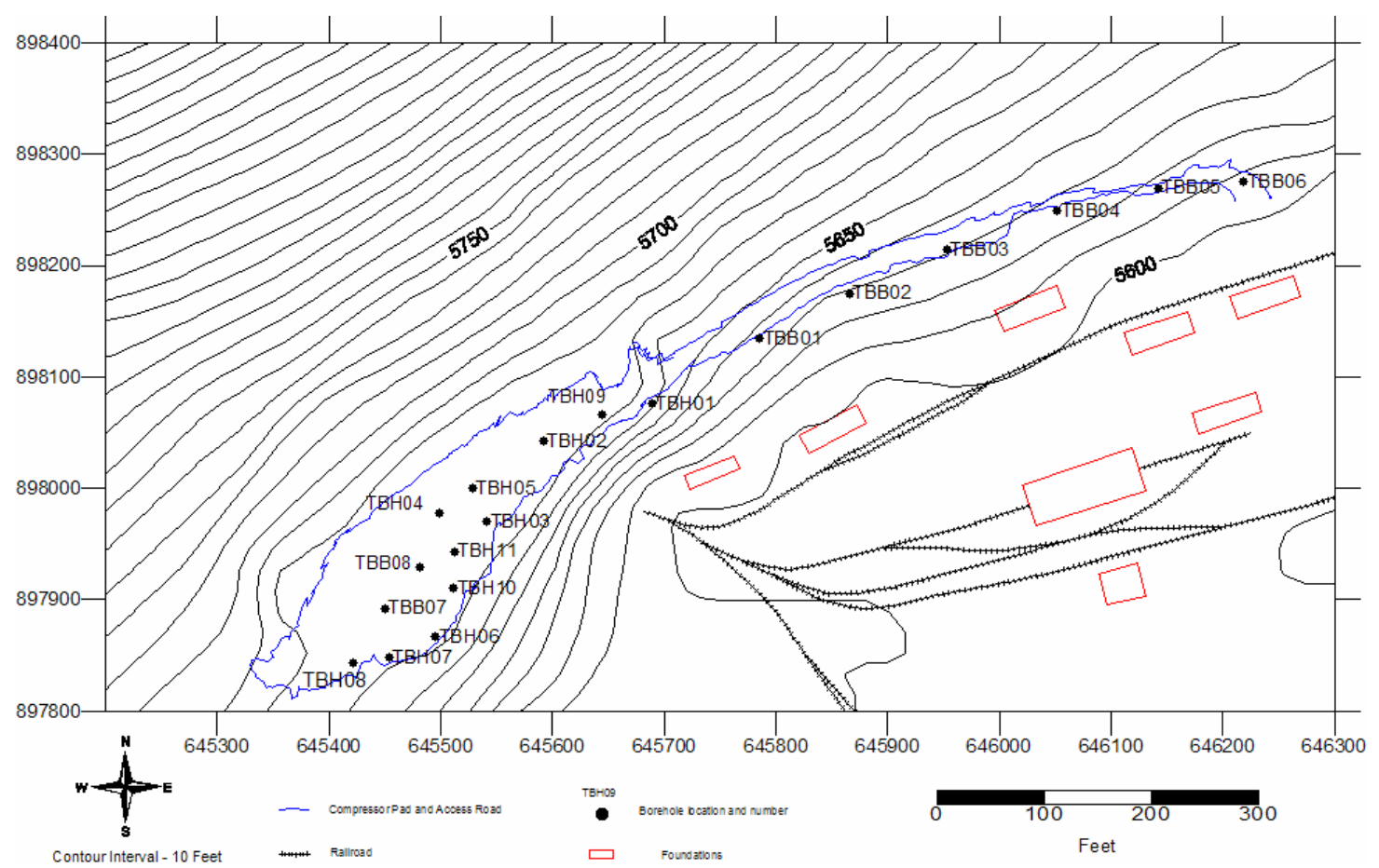

Figure A.2-2 CAU 559 Actual Borehole and Sample Locations

Two soil samples were collected from each randomly located borehole (see Table A.3-1) and one sample was collected from each hand sampled random location. In each drilled random borehole, one sample was collected at a randomly selected depth (the z-depth); however, if the native material contact was less than $1 \mathrm{ft}$, the sample was taken from 0 to $1 \mathrm{ft}$. For boreholes deeper than $1 \mathrm{ft}$, a sample was collected from the bottom of the borehole. One sample, from 0 to $0.5 \mathrm{ft}$, was collected from the hand sampled random location. Although the CAIP provided for the possibility of sampling sections of core where field screening indicated elevated alpha, beta, 
gamma, or VOC levels, no elevated field screening results were identified so no additional samples were collected.

One soil sample, from 0 to $0.5 \mathrm{ft}$, was taken from each of the biased locations. As specified in the CAIP, if the field screening identified elevated readings for any section of core, additional samples could be taken. No elevated field screening results were identified, so no additional samples were taken from the biased sample locations.

A total of 31 environmental samples including two duplicates were collected during the field investigation for this site. Thirteen environmental soil samples were collected to characterize the pad, 10 environmental soil samples were collected to characterize the native material underneath the pad, and six environmental samples were collected to characterize the access road. All of the soil samples were sent to EMAX Laboratory to be analyzed for VOCs, PCBs, SVOCs, TPH-DRO, TPH-GRO, beryllium, RCRA metals, and radionuclides.

\section{A.2.4 Background Native Soil Samples (0.5 ft)}

Background soil samples were not collected around the pad. When CAU 476 (T-Tunnel Muckpile) was characterized, three background samples were collected at undisturbed locations around the T-Tunnel Muckpile (Figure A.2-3). These locations are close enough to the T-Tunnel Compressor/Blower Pad to be used as background locations. The samples were analyzed for metals and radionuclides. The as-built sample location coordinates are shown in Table A.2-2.

\section{A.2.5 Other Sampling}

In addition to the environmental samples, $13 \mathrm{QA} / \mathrm{QC}$ samples were collected during the site characterization. The QA/QC samples included two blind duplicate samples, collected and analyzed to check on the laboratory's precision; two laboratory QC samples, collected to check for matrix interference; two rinsate samples, collected to check on the effectiveness of the decontamination procedures; two field blanks, collected to check on possible environmental interferences; and nine trip blanks, sent with the VOC samples. 
CAU 559 CADD/CR

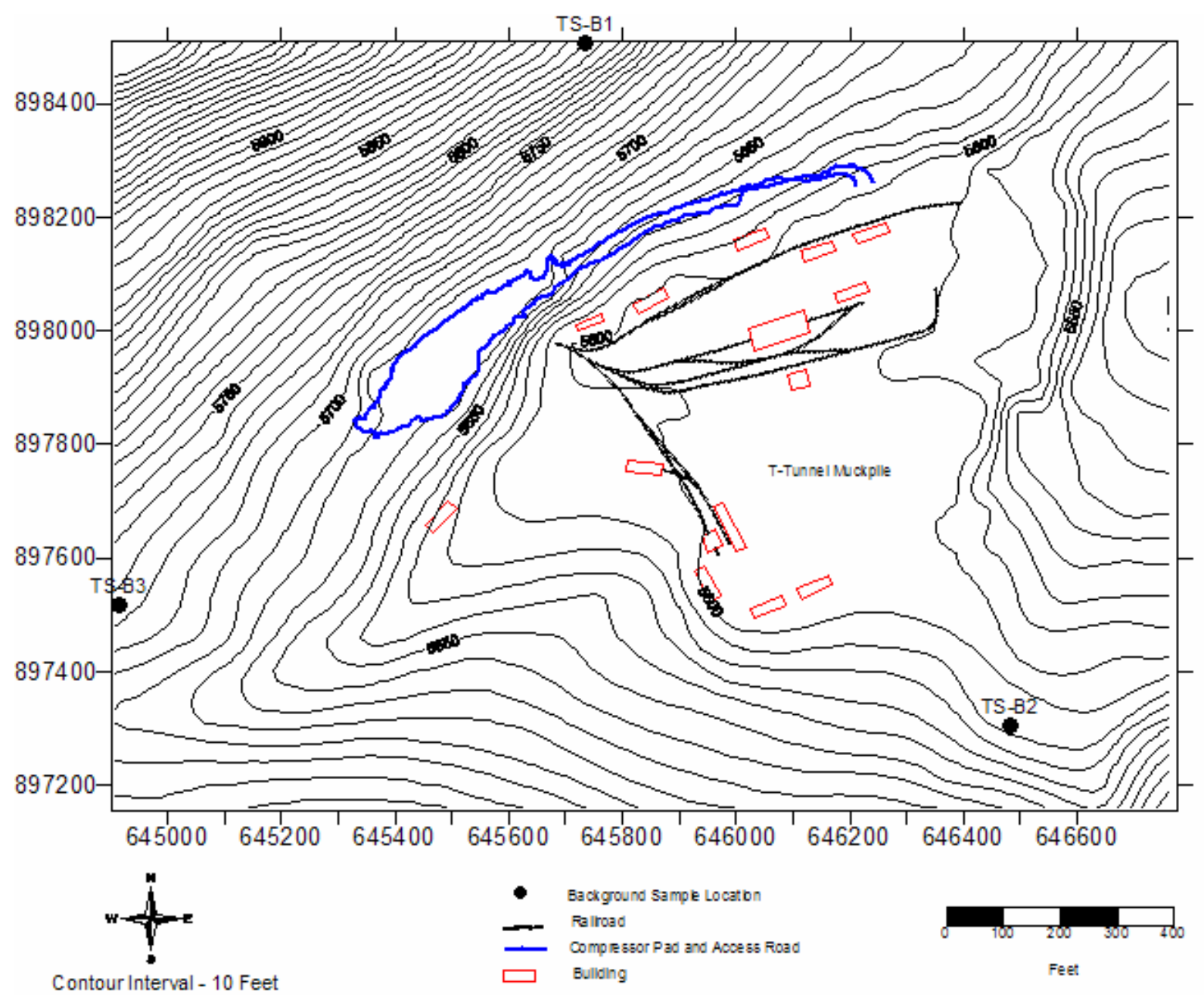

Figure A.2-3

CAU 476 Background Sample Locations 
Table A.2-2

CAU 559 Actual Borehole and Sample Locations

\begin{tabular}{||c|c|c|c||}
\hline Location Number & Northing & Easting & $\begin{array}{c}\text { Elevation } \\
\text { (feet) }\end{array}$ \\
\hline \hline \multicolumn{4}{|c||}{ Random Locations } \\
\hline TBH01 & 898076.1 & 645688.8 & $5,649.6$ \\
\hline TBH02 & 898042.8 & 645591.6 & $5,651.9$ \\
\hline TBH03 & 897970.5 & 645541.1 & $5,653.1$ \\
\hline TBH04 & 897978.1 & 645498.1 & $5,653.6$ \\
\hline TBH05 & 897999.8 & 645527.9 & $5,652.7$ \\
\hline TBH06 & 897867.4 & 645495.2 & $5,654.9$ \\
\hline TBH07 & 897848.5 & 645453.3 & $5,657.8$ \\
\hline TBH08 & 897843.1 & 645421.6 & $5,660.1$ \\
\hline TBH09 & 898066.1 & 645644.6 & $5,650.6$ \\
\hline & Biased Locations \\
\hline TBH10 & 897910.6 & 645511.3 & $5,654.0$ \\
\hline TBH11 & 897943.6 & 645512.1 & $5,653.5$ \\
\hline TBB01 & 898135.0 & 645785.2 & $5,643.3$ \\
\hline TBB02 & 898175.0 & 645865.5 & $5,639.3$ \\
\hline TBB03 & 898214.4 & 645953.1 & $5,634.0$ \\
\hline TBB04 & 898249.5 & 646051.8 & $5,625.1$ \\
\hline TBB05 & 898269.6 & 646142.2 & $5,614.0$ \\
\hline TBB06 & 898274.8 & 646218.6 & $5,605.5$ \\
\hline TBB07 & 897892.3 & 645449.6 & $5,656.1$ \\
\hline TBB08 & 897929.6 & 645481.4 & $5,654.1$ \\
\hline & & \\
\hline
\end{tabular}




\section{A.3.0 Results}

The analytical results of samples collected from the T-Tunnel Compressor/Blower Pad CAI have been compiled and evaluated to determine the presence and extent of the contamination. The results are summarized in the following subsections. Complete laboratory results are available in the project files.

A total of 29 soil samples (characterization) and 13 water samples (QC trip blanks, field blanks, and rinsate blanks) were collected and submitted for analysis. A list of sample numbers and their relationship to the boreholes is presented in Table A.3-1. The analytical parameters and methods requested for the CAI samples submitted to the off-site laboratory are presented in Table A.3-2. All samples were submitted to the EMAX Laboratory. Third-party data validation was completed by Tech-Law, Inc. The samples that had laboratory-reported detections (above the method detection limit) are summarized in Tables A.3-3 and A.3-4.

\section{A.3.1 Total Volatile Organic Compounds and Total Semivolatile Organic Compounds}

Volatile organic compounds and SVOCs were detected in samples throughout the pad soil and in one native soil sample at levels above the method detection limit. No VOCs or SVOCs were detected above the action levels presented in the CAIP (DTRA, 2005). All of the constituents detected are common laboratory artifacts.

\section{A.3.2 Polychlorinated Biphenyls}

Polychlorinated biphenyls were detected in three surface soil samples from the pad at levels above the method detection limit. One of these samples exceeded the PAL presented in the CAIP (DTRA, 2005).

\section{A.3.3 Total Petroleum Hydrocarbons}

There were no TPH-GRO concentrations that exceeded the method detection limit. There were 19 TPH-DRO samples that exceeded the method detection limit. Four of these detections also exceeded the $100 \mathrm{mg} / \mathrm{kg}$ action level presented in the CAIP (DTRA, 2005). Concentrations detected in the samples ranged from $120 \mathrm{mg} / \mathrm{kg}$ to $920 \mathrm{mg} / \mathrm{kg}$ (three from the pad and one from the road). All of the locations were in the 0- to 6-inch samples. Appendices $\mathrm{C}$ and $\mathrm{D}$ provide a detailed discussion of why these results meet the CAU 559 DQOs. 
Table A.3-1

Samples Collected and Submitted for Laboratory Analyses for the CAU 559 T-Tunnel Compressor/Blower Pad Corrective Action Investigation (Page 1 of 2)

\begin{tabular}{|c|c|c|c|c|c|c|}
\hline $\begin{array}{l}\text { Borehole } \\
\text { Number }\end{array}$ & $\begin{array}{l}\text { Sample } \\
\text { Number }\end{array}$ & $\begin{array}{c}\text { Depth } \\
\text { (ft bgs) }\end{array}$ & $\begin{array}{c}\text { Sample } \\
\text { Matrix }\end{array}$ & $\begin{array}{l}\text { Soil } \\
\text { Type }\end{array}$ & Comments & $\begin{array}{c}\text { Parameters } \\
\text { Analyzed }\end{array}$ \\
\hline \multirow{2}{*}{ TBH01 } & 559BH0100.5 & $0-1$ & Soil & Fill & - & Full Suite \\
\hline & 559BH0105.5 & $5-6$ & Soil & Native & - & Full Suite \\
\hline \multirow{2}{*}{ TBH02 } & 559BH0200.5 & $0-1$ & Soil & Fill & - & Full Suite \\
\hline & 559BН0203.5 & $3-4$ & Soil & Native & - & Full Suite \\
\hline \multirow{2}{*}{ TBH03 } & 559ВН0300.5 & $0-1$ & Soil & Fill & - & Full Suite \\
\hline & 559BH0303.5 & $3-4$ & Soil & Native & - & Full Suite \\
\hline \multirow{2}{*}{ TBHO4 } & 559BH0401.0 & $0.5-1.5$ & Soil & Fill & - & Full Suite \\
\hline & 559BH0405.5 & $5-6$ & Soil & Native & - & Full Suite \\
\hline \multirow{2}{*}{ TBH05 } & 559BH0500.5 & $0-1$ & Soil & Fill & - & Full Suite \\
\hline & 559BН0506.0 & $5.5-6.5$ & Soil & Native & - & Full Suite \\
\hline \multirow{2}{*}{ TBH06 } & 559BH0600.5 & $0-1$ & Soil & Fill & - & Full Suite \\
\hline & 559BH0604.0 & $3.5-4.5$ & Soil & Native & - & Full Suite \\
\hline \multirow{2}{*}{ TBH07 } & 559BH0701.0 & $0.5-1.5$ & Soil & Fill & - & Full Suite \\
\hline & 559BH0706.5 & $6-7$ & Soil & Native & - & Full Suite \\
\hline \multirow{2}{*}{ TBH08 } & 559BH0800.5 & $0-1$ & Soil & Fill & Full Laboratory QC & Full Suite \\
\hline & 559BH0805.0 & $4.5-5.5$ & Soil & Native & - & Full Suite \\
\hline \multirow{2}{*}{ TBH09 } & 559BH0900.5 & $0-1$ & Soil & Fill & - & Full Suite \\
\hline & 559BH0900.5X & $0-1$ & Soil & Fill & Duplicate of 559BH0900.5 & Full Suite \\
\hline \multirow{2}{*}{ TBH10 } & 559BH1000.5 & $0-1$ & Soil & Fill & - & Full Suite \\
\hline & 559BH1005.5 & $5-6$ & Soil & Native & - & Full Suite \\
\hline \multirow{2}{*}{ TBH11 } & 559BH1100.5 & $0-1$ & Soil & Fill & - & Full Suite \\
\hline & 559BH1105.5 & $5-6$ & Soil & Native & - & Full Suite \\
\hline TBB01 & 559BB0100.5 & $0-1$ & Soil & Fill & - & Full Suite \\
\hline TBB02 & 559BB0200.5 & $0-1$ & Soil & Fill & - & Full Suite \\
\hline TBB03 & 559BB0300.5 & $0-1$ & Soil & Fill & Full Laboratory QC & Full Suite \\
\hline TBB04 & 559BB0400.5 & $0-1$ & Soil & Fill & - & Full Suite \\
\hline TBB05 & 559BB0500.5 & $0-1$ & Soil & Fill & - & Full Suite \\
\hline \multirow{2}{*}{ TBB06 } & 559BB0600.5 & $0-1$ & Soil & Fill & - & Full Suite \\
\hline & 559BB0600.5X & $0-1$ & Soil & Fill & Duplicate of 559BB0600.5 & Full Suite \\
\hline TBB07 & 559BB0700.5 & $0-1$ & Soil & Fill & - & Full Suite \\
\hline TBB08 & 559BB0800.5 & $0-1$ & Soil & Fill & - & Full Suite \\
\hline $\begin{array}{c}\text { TB1 } \\
(\mathrm{CAU} 476)\end{array}$ & TS-B1 & $0-1$ & Soil & Native & Background & $\begin{array}{l}\text { RCRA Metals } \\
\text { Gamma Spec }\end{array}$ \\
\hline $\begin{array}{c}\text { TB2 } \\
(\mathrm{CA \cup} 476)\end{array}$ & TS-B2 & $0-1$ & Soil & Native & Background & $\begin{array}{l}\text { RCRA Metals } \\
\text { Gamma Spec }\end{array}$ \\
\hline
\end{tabular}


Table A.3-1

Samples Collected and Submitted for Laboratory Analyses for the CAU 559 T-Tunnel Compressor/Blower Pad Corrective Action Investigation

(Page 2 of 2)

\begin{tabular}{|c|c|c|c|c|c|c||}
\hline $\begin{array}{c}\text { Borehole } \\
\text { Number }\end{array}$ & $\begin{array}{c}\text { Sample } \\
\text { Number }\end{array}$ & $\begin{array}{c}\text { Depth } \\
\text { (ft bgs) }\end{array}$ & $\begin{array}{c}\text { Sample } \\
\text { Matrix }\end{array}$ & $\begin{array}{c}\text { Soil } \\
\text { Type }\end{array}$ & Comments & $\begin{array}{c}\text { Parameters } \\
\text { Analyzed }\end{array}$ \\
\hline \hline $\begin{array}{c}\text { TB3 } \\
\text { (CAU 476) }\end{array}$ & TS-B3 & $0-1$ & Soil & Native & Background & $\begin{array}{c}\text { RCRA Metals } \\
\text { Gamma Spec }\end{array}$ \\
\hline N/A & $559 C W 01$ & N/A & Water & N/A & Field Blank & Full Suite \\
\hline N/A & $559 C W 02$ & N/A & Water & N/A & Rinsate Blank & Full Suite \\
\hline N/A & $559 C W 03$ & N/A & Water & N/A & Field Blank & Full Suite \\
\hline N/A & $559 C W 04$ & N/A & Water & N/A & Rinsate Blank & Full Suite \\
\hline N/A & $559 T R 01$ & N/A & Water & N/A & Trip Blank & VOC \\
\hline N/A & $559 T R 02$ & N/A & Water & N/A & Trip Blank & VOC \\
\hline N/A & $559 T R 03$ & N/A & Water & N/A & Trip Blank & VOC \\
\hline N/A & $559 T R 04$ & N/A & Water & N/A & Trip Blank & VOC \\
\hline N/A & $559 T R 05$ & N/A & Water & N/A & Trip Blank & VOC \\
\hline N/A & $559 T R 06$ & N/A & Water & N/A & Trip Blank & VOC \\
\hline N/A & $559 T R 07$ & N/A & Water & N/A & Trip Blank & VOC \\
\hline N/A & $559 T R 08$ & N/A & Water & N/A & Trip Blank & VOC \\
\hline N/A & $559 T R 09$ & N/A & Water & N/A & Trip Blank & VOC \\
\hline \hline
\end{tabular}

Full Suite = VOC, SVOC, PCBs, TPH-GRO, TPH-DRO/oil, RCRA metals, beryllium, gamma spec, isotopic plutonium, strontium-90 $\mathrm{N} / \mathrm{A}=$ Not applicable

Table A.3-2

Chemical Analytical Methods Used for the T-Tunnel Compressor/Blower Pad Investigation Samples (Page 1 of 2)

\begin{tabular}{|c|c|c|}
\hline Analyte & Medium $^{\mathrm{a}}$ & Analytical Method \\
\hline \multirow{2}{*}{ Total VOCs } & Water & \multirow{2}{*}{$8260 B^{b}$} \\
\hline & Soil & \\
\hline \multirow{2}{*}{ Total SVOCs } & Water & \multirow{2}{*}{$8270 C^{b}$} \\
\hline & Soil & \\
\hline \multirow{2}{*}{ PCBs } & Water & \multirow{2}{*}{$8082^{b}$} \\
\hline & Soil & \\
\hline $\begin{array}{l}\text { Total RCRA Metals + Be } \\
\text { Arsenic } \\
\text { Barium } \\
\text { Cadmium } \\
\text { Chromium } \\
\text { Lead } \\
\text { Selenium } \\
\text { Silver }\end{array}$ & Water & $6010 \mathrm{~B}^{\mathrm{b}}$ \\
\hline
\end{tabular}


Table A.3-2

\section{Chemical Analytical Methods Used for the T-Tunnel Compressor/Blower Pad Investigation Samples} (Page 2 of 2)

\begin{tabular}{|c|c|c|}
\hline Analyte & Medium $^{a}$ & Analytical Method \\
\hline Mercury & Water & $7470 A^{b}$ \\
\hline $\begin{array}{l}\text { Arsenic } \\
\text { Barium } \\
\text { Cadmium } \\
\text { Chromium } \\
\text { Lead } \\
\text { Selenium } \\
\text { Silver }\end{array}$ & Soil & $6010 B^{b}$ \\
\hline Mercury & Soil & $7471 A^{b}$ \\
\hline \multirow{4}{*}{ Total Petroleum Hydrocarbons } & Water (gasoline) & \multirow{4}{*}{ 8015B modified ${ }^{b}$} \\
\hline & Water (diesel/oil) & \\
\hline & Soil (gasoline) & \\
\hline & Soil (diesel/oil) & \\
\hline \multirow{2}{*}{ Gamma Spectroscopy } & Water & EPA $901.1^{c, d}$ \\
\hline & Soil & HASL $300^{e, d}$ \\
\hline \multirow{2}{*}{ Isotopic Plutonium } & Water & Lab SQP $^{d}$ \\
\hline & Soil & HASL $300^{e, d}$ \\
\hline \multirow{2}{*}{ Strontium } & Water & EPA $905.0^{c, d}$ \\
\hline & Soil & HASL $300^{e, d}$ \\
\hline
\end{tabular}

${ }^{\text {a }}$ Includes methods for QC (water) samples.

${ }^{\mathrm{b}}$ Test Methods for Evaluating Solid Waste, 3rd Edition, Parts 1-4, SW-846 (EPA, 1996).

${ }^{c}$ Prescribed Procedures for Measurements of Radioactivity in Drinking Water, EPA-600/4-80-032 (EPA, 1980).

${ }^{d}$ or equivalent as approved by the project.

e Procedures Manual of the Environmental Measurements Laboratory, HASL-300 (DOE, 1997).

${ }^{\mathrm{f}}$ Standard Guide for Risk-Based Corrective Action Applied at Petroleum Release Sites (ASTM, 1995).

EPA $=$ U.S. Environmental Protection Agency

HASL $=$ Health and Safety Laboratory

$\mathrm{PCB}=$ Polychlorinated biphenyl

RCRA = Resource Conservation and Recovery Act

SQP = Standard Quality Practice

SVOC $=$ Semivolatile organic compound

$\mathrm{VOC}=$ Volatile organic compound

\section{A.3.3 Total RCRA Metals Results}

The RCRA metals were detected in samples throughout the pad and in native soil samples at levels that exceeded the method detection limits. However, none of the metals were detected above the action levels identified in the CAIP (DTRA, 2005). 


\section{A.3.4 Gamma Spectroscopy Results}

Four radionuclides were discovered in one biased sample (559BB0800.5) from the pad that exceeded the PALs presented in the CAIP: Co-60, Cs-137, Pu-239, and Sb-125. Other detected analytes were representative of naturally occurring isotopes in concentrations that were not statistically significant when compared to background. 
Table A.3-3

VOCs, SVOCs, and Total Metals Detects

for the CAU 559 T-Tunnel Compressor/Blower Pad Investigation

\begin{tabular}{|c|c|c|c|c|c|c|c|c|c|}
\hline Compounds & Units & $\begin{array}{l}\text { Background } \\
\text { Range }\end{array}$ & $\begin{array}{l}\text { No. of } \\
\text { Detects }\end{array}$ & $\begin{array}{l}\text { Pad Soil } \\
\text { Range }\end{array}$ & $\begin{array}{c}\text { No. of } \\
\text { Detects }\end{array}$ & $\begin{array}{l}\text { Native } \\
\text { Range }\end{array}$ & $\begin{array}{l}\text { No. of } \\
\text { Detects }\end{array}$ & QA/QC Range & $\begin{array}{c}\text { No. of } \\
\text { Detects }\end{array}$ \\
\hline \multicolumn{10}{|c|}{ Volatile Organic Compounds } \\
\hline Acetone & $\mu \mathrm{g} / \mathrm{kg}$ & & & $6-16$ & 3 & 5.9 & 1 & & \\
\hline Acetone & $\mu \mathrm{g} / \mathrm{L}$ & & & & & & & $7.9-8.4$ & 2 \\
\hline Trichlorofluoromethane & $\mu \mathrm{g} / \mathrm{kg}$ & & & 2.4 & 1 & & & & \\
\hline \multicolumn{10}{|c|}{ Semivolatile Organic Compounds } \\
\hline Bis(2-ethylhexyl)phthalate & $\mu \mathrm{g} / \mathrm{kg}$ & & & $260-1,700$ & 3 & & & & \\
\hline Bis(2-ethylhexyl)phthalate & $\mu g / L$ & & & & & & & 5.9 & 1 \\
\hline Dibromomethane & $\mu g / L$ & & & & & & & $1.2-1.4$ & 2 \\
\hline Dimethylphthalate & $\mu \mathrm{g} / \mathrm{kg}$ & & & 280 & 1 & & & & \\
\hline \multicolumn{10}{|c|}{ Polychlorinated Biphenyls } \\
\hline PCB 1260 & $\mu \mathrm{g} / \mathrm{kg}$ & & & $55-4,400$ & 4 & & & & \\
\hline \multicolumn{10}{|c|}{ Total Petroleum Hydrocarbons } \\
\hline TPH-DRO & $\mathrm{mg} / \mathrm{kg}$ & & & $5.6-920$ & 11 & 7.7 & 4 & & \\
\hline TPH-DRO & $\mathrm{mg} / \mathrm{L}$ & & & & & & & 0.49 & 1 \\
\hline \multicolumn{10}{|c|}{ Total Metals } \\
\hline Arsenic & $\mathrm{mg} / \mathrm{kg}$ & $2-3.8$ & 3 & $0.72-6.19$ & 19 & $0.97-6.17$ & 6 & & \\
\hline Arsenic & $\mathrm{mg} / \mathrm{L}$ & & & & & & & $0.00614-0.00643$ & 2 \\
\hline Barium & $\mathrm{mg} / \mathrm{kg}$ & $78-110$ & 3 & $70.5-4,350$ & 19 & $20.6-150$ & 10 & & \\
\hline Beryllium & $\mathrm{mg} / \mathrm{kg}$ & & & $0.48-0.95$ & 19 & $0.33-1.49$ & 9 & & \\
\hline Cadmium & $\mathrm{mg} / \mathrm{kg}$ & $0.046-0.088$ & 3 & $0.11-5.25$ & 8 & & & & \\
\hline Chromium & $\mathrm{mg} / \mathrm{kg}$ & $3.5-6$ & 3 & $1.63-20.2$ & 19 & $0.26-7.42$ & 10 & & \\
\hline Lead & $\mathrm{mg} / \mathrm{kg}$ & $9.1-12$ & 3 & $5.01-129$ & 19 & $1.13-12$ & 10 & & \\
\hline Mercury & $\mathrm{mg} / \mathrm{kg}$ & & & $0.04-0.09$ & 3 & $0.04-0.05$ & 2 & & \\
\hline Selenium & $\mathrm{mg} / \mathrm{kg}$ & & & 0.58 & 1 & & & & \\
\hline Silver & $\mathrm{mg} / \mathrm{kg}$ & & & $0.29-1.45$ & 12 & $0.35-13$ & 9 & & \\
\hline
\end{tabular}


Table A.3-4

Radionuclide Detects for the CAU 559 T-Tunnel Compressor/Blower Pad Investigation

\begin{tabular}{|c|c|c|c|c|c|c|c||}
\hline Radionuclide & Units & $\begin{array}{c}\text { Background } \\
\text { Range }\end{array}$ & $\begin{array}{c}\text { No. of } \\
\text { Detects }\end{array}$ & $\begin{array}{c}\text { Pad Soil } \\
\text { Range }\end{array}$ & $\begin{array}{c}\text { No. of } \\
\text { Detects }\end{array}$ & $\begin{array}{c}\text { Native } \\
\text { Range }\end{array}$ & $\begin{array}{c}\text { No. of } \\
\text { Detects }\end{array}$ \\
\hline \hline Actinium-228 & $\mathrm{pCi} / \mathrm{g}$ & $2.11-3.2$ & 3 & $1.4-2.94$ & 18 & $1.32-4.33$ & 10 \\
\hline Americium-241 & $\mathrm{pCi} / \mathrm{g}$ & 2.8 & 1 & & & & \\
\hline Bismuth-212 & $\mathrm{pCi} / \mathrm{g}$ & & & 2.79 & 1 & & 18 \\
\hline Bismuth-214 & $\mathrm{pCi} / \mathrm{g}$ & $1.16-2.4$ & 3 & $0.71-1.71$ & 18 & $0.76-2.71$ & 10 \\
\hline Cobalt-60 & $\mathrm{pCi} / \mathrm{g}$ & & & 6.18 & 1 & & 13 \\
\hline Cesium-137 & $\mathrm{pCi} / \mathrm{g}$ & $1.14-13.5$ & 2 & $0.31-1,530$ & 13 & $0.28-0.60$ & 2 \\
\hline Lead-212 & $\mathrm{pCi} / \mathrm{g}$ & $2.12-2.76$ & 3 & $1.5-3.1$ & 18 & $1.50-5.39$ & 10 \\
\hline Lead-214 & $\mathrm{pCi} / \mathrm{g}$ & $1.27-1.59$ & 3 & $1.04-1.6$ & 18 & $0.81-3.30$ & 10 \\
\hline Plutonium-238 & $\mathrm{pCi} / \mathrm{g}$ & $0.31-1.03$ & 2 & $0.06-11.9$ & 4 & 0.07 & 1 \\
\hline Plutonium-239 & $\mathrm{pCi} / \mathrm{g}$ & $0.10-9.6$ & 3 & $0.06-37.4$ & 13 & 0.35 & 1 \\
\hline Antimony-125 & $\mathrm{pCi} / \mathrm{g}$ & & & 22.6 & 1 & & 18 \\
\hline Strontium-90 & $\mathrm{pCi} / \mathrm{g}$ & & & $0.84-207$ & 2 & & 1 \\
\hline Thorium-234 & $\mathrm{pCi} / \mathrm{g}$ & & & 3.2 & & & $0.56-1.60$ \\
\hline Thallium-208 & $\mathrm{pCi} / \mathrm{g}$ & $0.70-0.88$ & 3 & $0.54-0.94$ & 18 & & 10 \\
\hline
\end{tabular}




\section{A.4.0 Quality Assurance}

The following text outlines the results of the QA/QC activities. Detailed information on the QA program for this CAI is contained in the Industrial Sites Quality Assurance Project Plan (QAPP) (NNSA/NV, 2002). A detailed data assessment is presented in Appendix C of this document.

Quality control results are typically discussed in terms of the five PARCC parameters (precision, accuracy, representativeness, completeness, and comparability) as described in the following sections.

\section{A.4.1 Precision}

Precision is a quantitative measure of the variability of a group of measurements from their average value. Precision is assessed by collecting and analyzing duplicate field samples and comparing the results with the original sample. Precision is also assessed by creating, analyzing, and comparing laboratory duplicates from one or more field samples. Precision is reported as relative percent difference (RPD), which is calculated as the difference between the measured concentrations of duplicate samples, divided by the average of the two concentrations, and multiplied by 100. Any deviations from these requirements have been documented and explained and the related data qualified accordingly. The qualification process is described in Section A.4.6.

\section{A.4.2 Accuracy}

Field accuracy is defined as the nearness of a measurement to the true or accepted reference value. It is the composite of the random and systematic components of the measurement system and measures bias in a measurement system. The random component of accuracy is measured and documented through the analyses of spiked samples. Sampling accuracy is assessed by evaluating the results of spiked samples and laboratory control samples. Accuracy measurements are calculated as percent recovery (\%R) by dividing the measured sample concentration by the true concentration and multiplying the quotient by 100 .

Field accuracy is assessed by confirming that the documents of record track the sample from origin, through transfer of custody, to disposal. The goal of field accuracy is for all samples to be collected from the correct locations at the correct time, placed in a correctly labeled container with the correct preservative, and sealed with custody tape to prevent tampering. All samples in this sampling event were properly collected and forwarded to the laboratory as described above. 


\section{A.4.3 Representativeness}

Representativeness expresses the degree to which sample data accurately and precisely represent a characteristic of a population, parameter variations at a sampling point, or an environmental condition (EPA, 1987). Sample representativeness was achieved through the implementation of a sampling program designed to ensure proper sampling locations, number of samples, and the use of validated analytical methods. Representativeness was assessed through analysis of duplicate samples. Representativeness of the samples taken in this sampling event was assured by collecting the required samples shown in Table A.3-1 and by analyzing them using the approved analytical methods shown in Table A.3-2.

\section{A.4.4 Completeness}

Completeness is defined as the percentage of measurements made that are judged to be valid. A sampling and analytical requirement with 90 percent confidence level was established for this project (DTRA, 2005). The sampling and analytical programs were executed in accordance with approved field sampling instructions (DTRA, 2005). The specified sampling locations were used as planned. All specified samples were collected and all sample containers reached the laboratory intact and properly preserved (when applicable). For all samples, sample temperature was maintained during shipment to the laboratory, and sample chain of custody was maintained during sample storage and shipment. The 90 percent completeness goal was met as discussed in Appendix C.

\section{A.4.5 Comparability}

Comparability is a qualitative parameter expressing the confidence with which one dataset can be compared to another (EPA, 1987). To ensure comparability, the CAU 559 field sampling activities were performed and documented in accordance with approved procedures; a standardized sampling approach and analytical methodology were used; and all samples were collected per the CAIP (DTRA, 2005). Approved standardized methods and procedures were also used to analyze and report the data (e.g., SW-846, "Methods and Contract Laboratory Program” [CLP] [EPA, 1996 and 1994a] and/or CLP-like data packages). This approach ensures that the data from this project can be compared to other datasets. Based on the minimum comparability requirements specified in the Industrial Sites QAPP (NNSA/NV, 2002), all requirements were met.

Sample-handling documentation, laboratory nonconformance reports, and the precision and accuracy of QC sample results were evaluated for their effect on the results of the associated environmental soil samples. The environmental sample results were then qualified according to 
processes outlined in the following section. Documentation of the data qualifications resulting from these reviews is retained in project files.

\section{A.4.6 Data Validation}

All laboratory data from samples collected at the T-Tunnel Compressor/Blower Pad have been evaluated for data quality according to EPA Functional Guidelines (EPA, 1994a and 1994b). These guidelines were implemented in a tiered process and are presented in the following text. Modifications to the laboratory-generated qualifiers were required to account for estimated values and associated blank contamination. No data rejected during the data evaluation process were used to support the conclusions presented in Section A.3.0. Only valid detections, whether estimated (i.e., J-qualified) or not, were used in supporting the conclusions.

Changes resulting from the data evaluation process are documented in project files and summarized in memoranda for each sample delivery group (SDG). These memoranda are maintained with the SDGs in the project files.

\section{A.4.6.1 Tier 1}

Tier 1 evaluation for chemical analysis examines (but is not limited to):

- Sample count/type consistent with chain of custody

- Analysis count/type consistent with chain of custody

- Correct sample matrix

- Significant problems stated in cover letter or case narrative

- Completeness of certificates of analysis

- Completeness of CLP or CLP-like packages

- Completeness of signatures, dates, and times on chain of custody

- Condition-upon-receipt variance form included

- Requested analyses performed on all samples

- Date received/analyzed given for each sample

- Correct concentration units indicated

- Correct detection limits achieved

- Electronic data transfer supplied

- Results reported for field and laboratory QC samples

- Whether or not the deliverable met the overall objectives of the project 


\section{A.4.6.2 Tier 2}

Tier 2 evaluation for chemical analysis examines (but is not limited to):

- Sample date, preparation date, and analysis date for each sample

- Holding time criteria met

- QC batch association for each sample

- Cooler temperature upon receipt

- Sample pH for aqueous samples, as required

- Detection limits properly adjusted for dilution, as required

- Blank contamination evaluated and applied to sample results/qualifiers

- Matrix spike/MSD \%Rs and RPDs evaluated and applied to laboratory results/qualifiers

- Field duplicate RPDs evaluated and applied to laboratory results/qualifiers

- Laboratory duplicate RPDs evaluated and applied to laboratory results/qualifiers

- Surrogate \%Rs evaluated and applied to laboratory results/qualifiers

- Laboratory control sample \%Rs evaluated and applied to laboratory results/qualifiers

\section{A.4.6.3 Tier 3}

Additional data quality considerations included in EPA data review functional guidelines are evaluated as a third party Tier 3 review. Tier 3 review of chemical results include the following additional evaluations:

- Mass spectrometer tuning criteria

- Initial and continuing calibration verification

- Internal standard evaluation

- Organic compound quantitation

- Inductively coupled plasma (ICP) interference check sample evaluation

- Graphite furnace atomic absorption QC

- ICP serial dilution effects

- Recalculation of all laboratory results from raw data

Tier 1 and 2 data evaluations are summarized in a memorandum for each SDG showing results and qualifiers that were changed and the reason for these changes. Tier 3 review was performed on at least five percent of the analytical data. The Tier 3 validation supported the Tier 1 and Tier 2 efforts and none of the qualifiers were changed. A report of the findings has been issued and included in the project files.

\section{A.4.7 Quality Control Samples}

Seventeen QC samples (i.e., trip blanks, equipment rinsate blanks, field duplicates, and full laboratory QCs) were collected and submitted for laboratory analysis, as shown in Table A.3-1. The blanks and duplicates were assigned individual sample numbers and sent to the laboratory 
"blind.” Additional samples were selected by the laboratory to be analyzed as laboratory replicates, duplicates, matrix duplicates, and full laboratory QCs. Documentation related to the collection and analysis of these samples is retained in project files.

\section{A.4.7.1 Field Quality Control Samples}

Equipment rinsate blanks were analyzed for the parameters listed on Table A.3-2 (trip blanks were analyzed for VOCs only) and showed contamination associated with common laboratory artifacts (acetone, bromomethane, and phthalate esters as defined in the EPA Functional Guidelines). These blank detections were used to qualify the results of the associated environmental samples according to EPA Functional Guidelines (EPA, 1994a and 1994b).

According to the EPA Functional Guidelines, no qualification action is taken if a compound is found in an associated blank, but not in the sample, or if a compound is found in the sample, but not in an associated blank. The action taken when a compound is detected in both the sample and the associated blank varies depending upon the analyte involved and is known as "The 5X/10X Rule.”

For most VOCs and SVOCs, an analyte detected in the sample above the instrument detection limits, that was also detected in an associated blank, is qualified as undetected (U) if the sample concentration is less than five times $(5 \mathrm{X})$ the blank concentration. For the common laboratory contaminants (methylene chloride, acetone, 2-butanone [methyl ethyl ketone], and phthalate esters [especially bis(2-ethylhexyl) phthalate]), the factor is raised to ten times (10X) the blank concentration. The sample result is elevated to the quantitation limit/sample detection limit, if it is not already reported at that level. For inorganics (metals), sample results concentrations detected above the instrument detection limit but less than five times (5X) the amount found in an associated blank are qualified as undetected (U). There are no documented common metallic laboratory contaminants as compared to VOCs and SVOCs, so the sample result is never altered using a "10X rule."

Documentation of the data qualifications resulting from the application of these guidelines is retained in project files as both hard copy and electronic media.

Two field duplicate soil samples were sent as blind samples to the laboratory to be analyzed for the analytical parameters listed in Table A.3-2. For these samples, the duplicate results precision (i.e., RPDs between the environmental sample results and their corresponding field duplicate sample results) were compared to criteria set forth in EPA Functional Guidelines (EPA, 1994a and 1994b), and the associated environmental sample results were qualified accordingly. 
The EPA Functional Guidelines give no required review criteria for field duplicate analyses comparability, but allow the data reviewer to exercise professional judgment. Both detections and nondetections are qualified as estimated ( $\mathrm{J}$ and UJ, respectively) if the RPD between an environmental sample and its field duplicate fall outside established criteria.

Two field samples were selected for use as full laboratory QC samples. The \%R of these samples (a measure of accuracy) and the RPDs in these sample results (a measure of precision) were compared to EPA Functional Guideline (EPA, 1994a and 1994b) criteria, and the results were used to qualify associated environmental sample results accordingly.

The EPA Functional Guidelines for review of organic data state that no data qualification action is taken on the basis of full laboratory QC results alone. The data reviewer exercises professional judgment in considering these results in conjunction with the results of laboratory control samples and other QC criteria in applying qualifiers to the data. Generally, if recovery criteria are greater than the upper acceptance limit, then positive sample results for the affected compounds are qualified as estimated $(\mathrm{J})$, and nondetections are not qualified. If recovery criteria are less than the lower acceptance limit, then positive sample results for the affected compounds are qualified as estimated (J) and nondetections are qualified as unusable (R). The RPD results of full laboratory QC samples that fall outside established criteria are applied to qualify detections and nondetections as estimated ( $\mathrm{J}$ and $\mathrm{UJ}$, respectively). The results of the field QC samples and how they affected the data are presented in Appendix C.

The EPA Functional Guidelines for inorganic data review allow professional judgment to be applied in evaluating the results of both matrix spikes and laboratory duplicates. Generally, if spike recoveries are greater than the upper acceptance limit or less than the lower acceptance limit, positive results are qualified as estimated $(\mathrm{J})$, and nondetections are either unqualified or qualified as estimated (UJ), respectively. If spike recoveries are grossly low (less than 30 percent), positive results are unqualified, and nondetections are unusable (R). The RPD between the environmental sample and its laboratory duplicate are compared to established criteria to qualify detections and nondetections as estimated ( $\mathrm{J}$ and $\mathrm{UJ}$, respectively). The results of the field QC samples and how they affected the data are presented in Appendix C.

\section{A.4.7.2 Laboratory Quality Control Samples}

Analysis of method QC blanks and laboratory control samples was performed for each parameter analyzed by Paragon Analytics, Inc. In addition, laboratory duplicate analysis was performed on several environmental samples per SDG. The results of these analyses were used to qualify 
associated environmental sample results according to EPA Functional Guidelines (EPA, 1994a and 1994b) as discussed above. The results are discussed in Appendix C.

\section{A.4.8 Nonconformances and Field Deficiencies}

No laboratory deficiencies were identified for this project. No field deficiencies were identified for this project. 


\section{A.5.0 Summary}

Analysis of the data generated from sampling activities conducted during corrective action investigation activities conducted at the T-Tunnel Compressor/Blower Pad indicates the following:

- Preliminary action levels were not exceeded for total VOCs or total SVOCs for any of the samples collected at the T-Tunnel Compressor/Blower Pad site.

- One biased soil sample (559BB0800.5) had concentrations of radionuclides known to be associated with weapons testing (Sb-125, Co-60, Cs-137, and Pu-239) at concentrations greater than the PALs.

- One sample (559BB0700.5DL) had a PCB 1260 concentration of $4.4 \mathrm{mg} / \mathrm{kg}$, which is greater than the PRG.

- TPH-DRO was detected at 11 random samples from the pad, 8 biased samples from the pad and road, and 10 native soil samples. Of these, four (one biased on the pad and three random from the pad) exceeded the $100 \mathrm{mg} / \mathrm{kg}$ PAL. 


\section{A.6.0 References}

ASTM, see American Society for Testing and Materials.

American Society for Testing and Materials. 1995. Standard Guide for Risk-Based Corrective Action Applied at Petroleum Release Sites, ASTM E 1739-95 (Reapproved 2002). Philadelphia, PA.

DOE, see U.S. Department of Energy.

DTRA, see Defense Threat Reduction Agency.

Defense Threat Reduction Agency. 2005. Corrective Action Investigation Plan for Corrective Action Unit 559: T-Tunnel Compressor/Blower Pad, Nevada Test Site, Rev. 0. Las Vegas, NV.

EPA, see U.S. Environmental Protection Agency.

FFACO, see Federal Facility Agreement and Consent Order.

Federal Facility and Consent Order. 1996 (as amended). Agreed to by the State of Nevada, the U.S. Department of Energy, and the U.S. Department of Defense.

Gilbert, R.O. 1987. Statistical Methods for Environmental Pollution Monitoring. Chapter 4. New York, NY: Van Nostrand Reinhold.

NNSA/NV, see U.S. Department of Energy, National Nuclear Security Administration Nevada Operations Office.

SNJV, see Stoller-Navarro Joint Venture.

Stoller-Navarro Joint Venture. 2005. Site-Specific Health and Safety Plan, DTRA CAU 503 N-Tunnel Compressor/Blower Pad; CAU 559 T-Tunnel Compressor/Blower Pad, Nevada Test Site, Rev. 0. Las Vegas, NV.

U.S. Department of Energy. 1997. Procedures Manual of the Environmental Measurements Laboratory, HASL-300. Vol. 1., $28^{\text {th }}$ Ed. New York, NY.

U.S. Department of Energy, National Nuclear Security Administration Nevada Operations Office. 2002. Industrial Sites Quality Assurance Project Plan, Nevada Test Site, Nevada, DOE/NV--372. Rev. 3. Las Vegas, NV.

U.S. Environmental Protection Agency. 1980. Prescribed Procedures for Measurements of Radioactivity in Drinking Water, EPA-600/4-80-032. Washington, DC.

U.S. Environmental Protection Agency. 1987. Data Quality Objectives for Remedial Response Activities, EPA/540/G-87-003. Washington, DC. 
U.S. Environmental Protection Agency. 1994a. Contract Laboratory Program National Functional Guidelines for Organic Data Review, EPA 540/R-94/012. Washington, DC.

U.S. Environmental Protection Agency. 1994b. Contract Laboratory Program National Functional Guidelines for Inorganic Data Review, EPA 540/R-94/013. Washington, DC.

U.S. Environmental Protection Agency. 1996. Test Methods for Evaluating Solid Waste, Physical/Chemical Methods, SW-846, CD ROM. Washington, DC. 


\section{Appendix B \\ Data Quality Objective Process for CAU 559, T-Tunnel Compressor/Blower Pad}




\section{B.1.0 Data Quality Objective Process for CAU 559, T-Tunnel Compressor/Blower Pad}

The DQO process is a planning approach based on the scientific method that is used to ensure that data collected during site characterization will provide sufficient and reliable information to identify, evaluate, and technically defend potentially viable corrective actions (i.e., no further action, closure in place, or clean closure). The existing information about the nature and extent of contamination at CAU 559 is insufficient to evaluate and select preferred corrective actions. The CAU 559 investigation will be based on DQOs agreed to by representatives of NDEP and Defense Threat Reduction Agency (DTRA).

One CAS comprises CAU 559:

- CAS 12-25-13 Oil Stained Soil and Concrete

In addition, the CAI will evaluate the access road from the T-Tunnel Muckpile to the Compressor/Blower Pad.

The main steps of the DQO process are:

- State the problem.

- Identify the decision.

- Identify inputs to the decision.

- Define the study boundaries.

- Develop decision rules.

- Specify limits on the decision error.

- Optimize the design.

The seven steps and their application to the Compressor/Blower Pad are described in the following sections.

\section{B.1.1 State the Problem}

This step identifies the DQO planning team members, states the problem that has initiated the CAU 559 investigation, and develops the CSM. 


\section{B.1.1.1 Planning Team Members}

The DQO planning team consists of representatives from NDEP, DTRA, and the Environmental Engineering Subcontractor (EESC). The primary decision-makers are NDEP and DTRA representatives. Table B.1-1 lists representatives from each organization who attended the November 15, 2004, meeting held to present and discuss the DQOs for CAU 559.

Table B.1-1

Data Quality Objective Meeting Participants

\begin{tabular}{||l|l||}
\hline \multicolumn{1}{|c||}{ Participant } & \multicolumn{1}{c||}{ Affiliation } \\
\hline \hline Tiffany Lantow & DTRA \\
\hline Wayne Griffin & EESC/DTRA \\
\hline Chris Andres & NDEP \\
\hline Barbara Ground & EESC/Quality Assurance \\
\hline Stacey Alderson & EESC/Health Physicist \\
\hline Rick Deshler & EESC/Project Manager \\
\hline David Schrock & EESC/Waste Management \\
\hline Jack Ellis & EESC/Health Safety \\
\hline Sylvan Hersh & EESC \\
\hline Mark McLane & EESC \\
\hline \hline
\end{tabular}

DTRA = Defense Threat Reduction Agency

EESC $=$ Environmental Engineering Subcontractor

NDEP $=$ Nevada Division of Environmental Protection

\section{B.1.1.2 State the Problem}

It is unknown whether COPCs exceeding PALs are present in or beneath the T-Tunnel Compressor Pad, including the access road. It is also unknown whether COPCs have migrated from these sites. If contaminants are present in concentrations that exceed the PALs, they may present a risk to human health and/or the environment and have the potential for migrating off site. If contaminants are present, their nature and extent need to be determined and their risk to human health and/or the environment evaluated.

\section{B.1.2 Identify the Decision}

This step develops the decision statement. 


\section{B.1.2.1 Develop the Decision Statement}

The decision statement is, "Are there concentrations of COPCs present in the Compressor/Blower Pad that exceed the action levels and, if so, do they pose a threat to human health and/or the environment?”

\section{B.1.3 Identify Inputs to the Decision}

This step identifies the information needed, determines sources for the information, determines the basis for establishing the action levels, and identifies sampling and analysis methods that will be used to meet the data requirements.

\section{B.1.3.1 Conceptual Site Model}

A CSM has been developed to describe potential exposure pathways from possible contaminant sources in the Area $12 \mathrm{~T}$-Tunnel Compressor/Blower Pad. If the CSM is proven incorrect by the results of the environmental sampling, NDEP will be notified and the CAI rescoped. The following statements are assumptions and/or facts that were considered in developing the model:

- The pad was placed on a thin veneer of native alluvium and fill overlying the tuffs of the Calico Hills Formation.

- The T-Tunnel Compressor/Blower Pad consists of native alluvium and fill.

- The pad is approximately $150 \mathrm{ft}$ across at its widest point and $375 \mathrm{ft}$ long in a southwestnortheast direction. The thickness of the pad ranges from less than $1 \mathrm{ft}$ to approximately $10 \mathrm{ft}$.

- Arsenic is found in the native soils and may also be found in the pad (NBMG, 1998). In addition, the pad may also contain very small volumes of RCRA-regulated hazardous constituents and beryllium. The possible distribution of these COPCs is not known.

- Although specific permeability data are lacking, low precipitation and high evaporation rates in this region would tend to limit downward migration of contaminants on the pad.

- Past surface activities of concern include equipment maintenance and storage of equipment and petroleum products. Releases to the pad from surface activities could be locally significant, but vertical infiltration of contaminants is probably limited to less than $5 \mathrm{ft}$.

- It is unknown whether there is radiological contamination on the pad or the access road. 
- The most likely pathway for migration of contaminants away from the pad is in storm water runoff down the access road. Migration might also result when precipitation infiltrates into the thin, fill of the pad and enters the native material or bedrock.

- Possible future uses of the pad might include surface activities that would intrude into the pad to a depth of no more than $3 \mathrm{ft}$.

The CSM was developed using these assumptions. It was postulated that the majority of the pad does not contain COPCs, and if any COPCs are present, they are probably isolated. Because there are no records concerning the precise subsurface distribution of fill materials, the location of buried COPCs cannot be predicted. Operational knowledge and radiological surveys can be used to increase the probability of finding impacted areas of the pad. The areas most likely to be affected are the areas where petroleum compounds were used, possibly resulting in releases to the surface and shallow subsurface ( 0 to $5 \mathrm{ft}$ ) soils. These releases, if present, are expected to have limited lateral and vertical extent. It is also possible, but unlikely, that the native soil beneath the pad and access road has been impacted by downward migration of COPCs. Figure B.1-1 is a generalized drawing of the CSM.

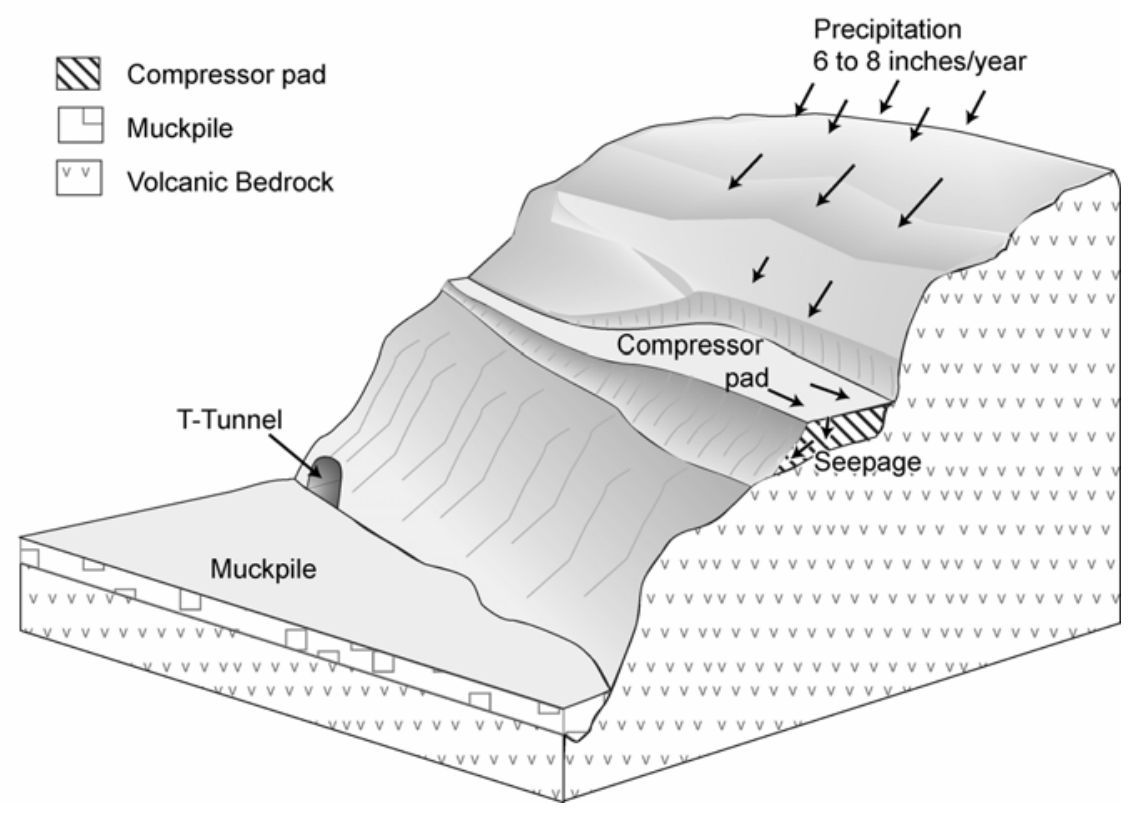

Figure B.1-1

CAU Conceptual Site Model 


\section{B.1.3.2 Information Needs and Information Sources}

Inputs to the decision are centered on the sampling approach, which depends foremost on a reasonable CSM. The model provides a basis for development of the approach and ultimately the course of action that will be taken for the site. In turn, the CSM is tested and confirmed by the results of the sampling. The sampling will consist of collecting random and possibly biased environmental samples from the pad and access road.

Table B.1-2 lists the information needs, the source of information for each need, the proposed methods to collect the data, and the quality assurance (QA)/quality control (QC) data type. The data type is determined by the intended use of the resulting data in decision making. Data types are discussed in the following text.

Table B.1-2

Information Needs To Resolve the Decision (Page 1 of 2)

\begin{tabular}{|l|l|l|l||}
\hline \multicolumn{1}{|c|}{ Information Need } & Information Source & \multicolumn{1}{|c||}{ Collection Method } & Data Type \\
\hline \hline $\begin{array}{l}\text { Identify the } \\
\text { contaminants of } \\
\text { concern (COPCs). }\end{array}$ & $\begin{array}{l}\text { - Results of historical } \\
\text { data review } \\
\text { - Results of the } \\
\text { walkover radiological } \\
\text { survey }\end{array}$ & $\begin{array}{l}\text { - Review the source terms for all tests } \\
\text { that could have contributed } \\
\text { contaminants to the pad. } \\
\text { - Review historical data for chemicals that } \\
\text { may have been used on site. } \\
\text { - Review historical data for potential } \\
\text { release information. }\end{array}$ & Qualitative \\
\hline $\begin{array}{l}\text { Are any COPCs } \\
\text { present in the } \\
\text { Compressor Pad? }\end{array}$ & $\begin{array}{l}\text { - Analytical results of } \\
\text { Soil samples }\end{array}$ & $\begin{array}{l}\text { - Collect soil samples at random locations } \\
\text { and at random depths in the pad and } \\
\text { access road, utilizing a rotosonic drill rig. } \\
\text { - Collect near surface biased soil samples } \\
\text { as needed using the rotosonic drill rig or } \\
\text { hand tools. } \\
\text { - Send samples to an off-site laboratory to } \\
\text { be analyzed for chemical and } \\
\text { radiological constituents. }\end{array}$ & \\
\hline $\begin{array}{l}\text { Are any COPCs } \\
\text { present in the native } \\
\text { material beneath the } \\
\text { pad? }\end{array}$ & $\begin{array}{l}\text { - Analytical results of } \\
\text { soil samples }\end{array}$ & $\begin{array}{l}\text { - Collect soil samples of native material at } \\
\text { various locations immediately beneath } \\
\text { the pad and access road utilizing a } \\
\text { rotosonic drill rig. } \\
\text { - Send all samples to an off-site } \\
\text { laboratory to be analyzed for chemical } \\
\text { and radiological constituents. }\end{array}$ & Quantitative \\
\hline
\end{tabular}


Table B.1-2

Information Needs To Resolve the Decision (Page 2 of 2)

\begin{tabular}{|c|c|c|c|}
\hline Information Need & Information Source & Collection Method & Data Type \\
\hline $\begin{array}{l}\text { If COPCs are present in } \\
\text { or beneath the } \\
\text { Compressor Pad, are } \\
\text { the concentrations high } \\
\text { enough to exceed } \\
\text { preliminary action } \\
\text { levels (PALs)? }\end{array}$ & $\begin{array}{l}\text { - Analytical results of } \\
\text { soil samples collected } \\
\text { with the drill rig } \\
\text { - EPA Region 9 PRG } \\
\text { (EPA, 2004) } \\
\text { - NAC 445.2272 } \\
\text { (NAC, 2002) } \\
\text { - Individual isotope and } \\
\text { metals concentrations } \\
\text { in background soil } \\
\text { samples } \\
\text { - Individual isotope and } \\
\text { metals concentrations } \\
\text { from published } \\
\text { sources }\end{array}$ & $\begin{array}{l}\text { - Compare the analytical results from the } \\
\text { off site laboratory for the chemical and } \\
\text { radiological data to the PALs taking into } \\
\text { account that the site is an industrial } \\
\text { facility in a nuclear and high explosives } \\
\text { test zone. }\end{array}$ & Quantitative \\
\hline $\begin{array}{l}\text { If COPCs are present in } \\
\text { concentrations that } \\
\text { exceed the PALs, what } \\
\text { is their extent? }\end{array}$ & $\begin{array}{l}\text { - Analytical results of } \\
\text { soil samples } \\
\text { - Results of the } \\
\text { walkover radiological } \\
\text { survey } \\
\text { - Field-screening } \\
\text { results collected with } \\
\text { the Electra } \\
\text { - Analytical results from } \\
\text { soil samples run on } \\
\text { the high-purity } \\
\text { germanium (HPGe) } \\
\text { gamma counter. }\end{array}$ & $\begin{array}{l}\text { - The walkover radiological and visual } \\
\text { surveys will be used to determine the } \\
\text { lateral extent of any contamination. } \\
\text { - Boreholes will be continued until two } \\
\text { consecutive drilling intervals are below } \\
\text { the field-screening levels as determined } \\
\text { from Electra and HPGe results (unless } \\
\text { refusal is encountered) to define the } \\
\text { vertical extent. }\end{array}$ & Quantitative \\
\hline $\begin{array}{l}\text { If COPCs are present in } \\
\text { concentrations that } \\
\text { exceed PALs, is there a } \\
\text { potential for migration? }\end{array}$ & $\begin{array}{l}\text { - Analytical results of } \\
\text { soil samples } \\
\text { - Results of the } \\
\text { walkover radiological } \\
\text { survey } \\
\text { - Stability and drainage } \\
\text { surveys }\end{array}$ & $\begin{array}{l}\text { - Assess existing data for usability and } \\
\text { collect geotechnical samples if needed. } \\
\text { - Evaluate the results of the surveys to } \\
\text { determine the stability of the pad }\end{array}$ & Semiquantitative \\
\hline
\end{tabular}

$E P A=U . S$. Environmental Protection Agency

$\mathrm{NAC}=$ Nevada Administrative Code

$P R G=$ Preliminary remediation goal

\section{B.1.3.1.1 Quantitative Data}

Quantitative data directly measure the quantity or amount of a characteristic or component within the population of interest. These data require the highest level of QA/QC in collection and measurement systems because the intended use of the data is to resolve primary decisions 
(i.e., rejecting or accepting the null hypothesis) and/or verifying that closure standards have been met. Laboratory analytical data are generally considered quantitative.

\section{B.1.3.1.2 Semiquantitative Data}

Semiquantitative data indirectly measure the quantity or amount of a characteristic or component. Inferences are drawn about the quantity or amount of a characteristic or component because a correlation has been shown to exist between the indirect measurement and the results from a quantitative measurement. The QA/QC requirements on semiquantitative collection and measurement systems are high but may not be as rigorous as a quantitative measurement system. Semiquantitative data contribute to decision making but are not used alone to resolve primary decisions. Field-screening data are generally considered semiquantitative. The data are often used to guide investigations toward quantitative data collection.

\section{B.1.3.1.3 Qualitative Data}

Qualitative data identify or describe the characteristics or components of the population of interest. The QA/QC requirements are the least rigorous on data collection methods and measurement systems. The intended use of the data is for information purposes, to refine CSMs, and to guide investigations rather than resolve primary decisions. This measurement of quality is typically assigned to historical information and data where QA/QC may be highly variable or not known. Professional judgment is often used to generate qualitative data.

\section{B.1.3.1.4 Determine the Basis for the Preliminary Action Levels}

Laboratory analytical results for soils will be compared to the following PALs to evaluate whether COPCs are present at levels that may pose an unacceptable risk to human health and/or the environment:

- $100 \mathrm{mg} / \mathrm{kg}$ TPH in soil, per NAC 445A.2272, “Contamination of Soils: Establishment of Action Levels” (NAC, 2002)

- Background concentrations for metals when natural background exceeds the preliminary remediation goal (PRG), as is often the case with arsenic, is considered the highest measurement from soil samples taken as local background or from soil samples collected by the Nevada Bureau of Mines and Geology throughout the Nellis Air Force Range (NBMG, 1998; Moore, 1999). 
- The U.S. Environmental Protection Agency (EPA) Region 9 PRGs (EPA, 2004) for industrial soils, as based on future use of the site in a Nuclear and High Explosive Test Zone (DOE/NV, 1996a and b and 1998).

- The PALs for radionuclides are isotope-specific and defined as the higher of the maximum concentration for that isotope found in samples from undisturbed background locations in the vicinity of the Nevada Test Site (McArthur and Miller, 1989; US Ecology and Atlan-Tech, 1992; Black and Townsend, 1996), from any of the three background samples collected during the investigation, or the recommended screening limits in the National Council on Radiation Protection and Measurement (NCRP) Report No. 129 (NCRP, 1999) recommended screening limits for construction, commercial, industrial land-use scenarios scaled from 25- to 15-mrem/yr dose and the generic guidelines for residual concentration of radionuclides in DOE Order 5400.5 (DOE, 1993).

\section{B.1.3.1.5 Potential Sampling Techniques and Appropriate Analytical Methods}

\section{B.1.3.1.5.1 Radiological Surveys}

Radiological surveys will be used to help determine the presence and lateral extent of radiological contamination. Radiological surveys will follow standard procedures. Further information is provided in Section B.1.7.1.

\section{B.1.3.1.5.2 Soil Sampling}

Rotosonic drilling and hand tools will be used to collect the soil samples. Soil sample collection and handling activities will follow standard procedures. Section 6.0 of the CAIP lists analytical methods and laboratory requirements (e.g., detection limits, precision, and accuracy) for the investigation. Sample volumes are laboratory and method-specific and will be determined in accordance with laboratory requirements. Specific analyses required for the disposal of investigation-derived waste are identified in Section 5.0 of the CAIP (DTRA, 2005).

To ensure that laboratory analyses are sufficient to detect contamination in soil samples at concentrations exceeding the minimum reporting limit, chemical and/or radiological parameters of interest have been selected for the CAU. The chemical and radiological parameters are listed in Table B.1-3. 
Table B.1-3

Analyses To Be Performed

\begin{tabular}{|c|c|c|c|c|c|c|c|}
\hline \multirow[b]{2}{*}{ Analyses } & \multicolumn{7}{|c|}{ Sample Type } \\
\hline & 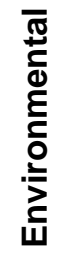 & 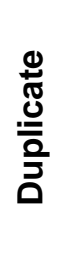 & 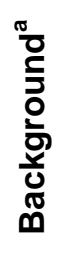 & $\begin{array}{l}\text { U } \\
\text { 色 } \\
\bar{\Xi} \\
\overline{\bar{J}}\end{array}$ & 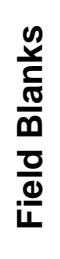 & 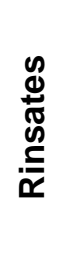 & 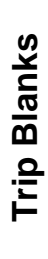 \\
\hline \multicolumn{8}{|c|}{ Organics } \\
\hline VOCs & $x$ & $x$ & & $x$ & $x$ & $x$ & $x$ \\
\hline SVOCs & $x$ & $x$ & & $x$ & $x$ & $x$ & \\
\hline PCBs & $X$ & $\mathrm{X}$ & & $x$ & $x$ & $X$ & \\
\hline TPH-DRO & $\mathrm{X}$ & $\mathrm{X}$ & & $x$ & $x$ & $x$ & \\
\hline TPH-GRO & $x$ & $x$ & & $x$ & $x$ & $x$ & \\
\hline \multicolumn{8}{|c|}{ Metals } \\
\hline Total RCRA Metals & $X$ & $x$ & $x$ & $x$ & $x$ & $x$ & \\
\hline Beryllium & $x$ & $x$ & $\mathrm{X}$ & $x$ & $x$ & $\mathrm{X}$ & \\
\hline \multicolumn{8}{|c|}{ Radionuclides } \\
\hline Gamma Spectrometry & $X$ & $x$ & $X$ & & $X$ & $X$ & \\
\hline Isotopic Plutonium & $\mathrm{X}$ & $x$ & $x$ & $x$ & $x$ & $x$ & \\
\hline Total Strontium ${ }^{b, c}$ & $x$ & $x$ & $x$ & $x$ & $X$ & $x$ & \\
\hline
\end{tabular}

${ }^{a}$ Background samples from CAU 476 T-Tunnel Muckpile.

${ }^{\mathrm{b}}$ Total strontium uses a stable strontium carrier as opposed to a radioactive tracer.

${ }^{\mathrm{c}}$ Although total strontium is measured, the results are reported as strontium-90 because strontium- 89 has too short a half-life to be present.

DRO = Diesel-range organics

$\mathrm{GRO}=$ Gasoline-range organics

$\mathrm{PCB}=$ Polychlorinated biphenyl

$\mathrm{QC}=$ Quality control
RCRA = Resource Conservation and Recovery Act SVOC $=$ Semivolatile organic compound $\mathrm{TPH}=$ Total petroleum hydrocarbons

VOC $=$ Volatile organic compound 
The VOCs and SVOCs expected to be analyzed for in the investigation are listed in Tables B.1-4 and B.1-5, respectively.

Table B.1-4

\section{Proposed VOCs for Analysis}

\begin{tabular}{|l|l|l||}
\hline 1,1,1-Trichloroethane & 2-Chlorotoluene & Ethylbenzene \\
\hline 1,1,2-Trichloroethane & 4-Methyl-2-pentanone & lodomethane \\
\hline 1,1,1,2-Tetrachloroethane & Acetone & Isopropylbenzene \\
\hline 1,1,2,2-Tetrachloroethane & Benzene & Methyl tertiary butyl ether \\
\hline 1,2,3-Trichloropropane & Bromobenzene & Methylene chloride \\
\hline 1,2,4-Trimethyl-benzene & Bromochloromethane & n-Butylbenzene \\
\hline 1,2-Dibromo-3-chloropropane & Bromodichloromethane & n-Propyl benzene \\
\hline 1,2-Dibromoethane & Bromoform & Sec-butyl benzene \\
\hline 1,1-Dichloroethane & Bromomethane & Styrene \\
\hline 1,1-Dichloroethene & Carbon disulfide & Tert-butyl benzene \\
\hline cis-1,2-Dichloroethene & Carbon tetrachloride & Tetrachloroethene \\
\hline trans-1,2-Dichloroethene & Chlorobenzene & Toluene \\
\hline 1,2-Dichloroethane & Chloroethane & Trichloroethene \\
\hline 1,2-Dichloropropane & Chloroform & Trichlorofluoromethane \\
\hline 1,3,5-Trimethylbenzene & Chloromethane & Trichlorotrifluoroethane \\
\hline cis-1,3-Dichloropropene & Dibromochloromethane & Vinyl acetate \\
\hline trans-1,3-Dichloropropene & Dibromomethane & Vinyl chloride \\
\hline 2-Butanone & Dichlorodifluoromethane & Xylene \\
\hline
\end{tabular}


Table B.1-5

\section{Proposed SVOCs for Analysis}

\begin{tabular}{|c|c|c|}
\hline 1,2,4-Trichlorobenzene ${ }^{a}$ & Acenaphthene & Di-n-butyl phthalate \\
\hline 1,2-Dichlorobenzene ${ }^{a}$ & Aniline & Di-n-octyl phthalate \\
\hline 1,3-Dichlorobenzene ${ }^{a}$ & Anthracene & Fluoranthene \\
\hline 1,4-Dichlorobenzene & Benzo(a)anthracene & Fluorene \\
\hline 2,4,5-Trichlorophenol & Benzo(a)pyrene & Hexachlorobenzene \\
\hline 2,4,6-Trichlorophenol & Benzo(b)fluoranthene & Hexachlorobutadiene $^{a}$ \\
\hline 2,4-Dichlorophenol & Benzo(k)fluoranthene & Hexachlorocyclopentadiene \\
\hline 2,4-Dimethylphenol & Benzoic acid & Hexachloroethane \\
\hline 2,4-Dinitrophenol & Benzyl alcohol & Indeno(1,2,3-cd)pyrene \\
\hline 2,4-Dinitrotoluene & Bis(2-chloroethoxy) methane & Isophorone \\
\hline 2,6-Dinitrotoluene & Bis(2-chloroethyl)ether & Naphthalene $^{\mathrm{a}}$ \\
\hline 2-Chloronaphthalene & Bis(2-chloroisopropyl)ether & Nitrobenzene \\
\hline 2-Chlorophenol & Bis(2-ethylhexyl) phthalate & N-Nitroso-di-n-propylamine \\
\hline 2-Methylphenol & Butyl benzyl phthalate & N-Nitrosodiphenylamine \\
\hline 2-Nitroaniline & Carbazole & Pentachlorophenol \\
\hline 3,3'-Dichlorobenzidine & Chrysene & Phenol \\
\hline 4-Bromophenyl phenyl ether & Dibenzo(a,h)anthracene & Pyrene \\
\hline 4-Chloroaniline & Dibenzofuran & Pyridine \\
\hline 4-Methylphenol & Diethyl phthalate & \\
\hline 4-Nitrophenol & Dimethyl phthalate & \\
\hline
\end{tabular}

${ }^{\mathrm{a}}$ May be reported with VOCs

\section{B.1.4 Definition of Study Boundaries}

The purpose of this step is to define the target population of interest, specify the spatial and temporal features of the population that are pertinent for decision making, determine practical constraints on data collection, and define the scale of decision making relevant to target populations.

\section{B.1.4.1 Define the Target Population}

The target populations for the characterization are:

- The material in the T-Tunnel Compressor/Blower Pad and access road.

- The native material underlying the pad and access road to a depth of no more than $5 \mathrm{ft}$ below the native interface. 


\section{B.1.4.2 Identify the Spatial and Temporal Boundaries}

The horizontal boundaries of the study area are the edges of the pad and access road to the extent that elevated radiological readings may be identified by the walkover surveys. The vertical boundary is 2 to $5 \mathrm{ft}$ below the bottom of the pad and access road or until drill refusal (defined as requiring more than 15 minutes to drill $1 \mathrm{ft}$ ). There are no temporal constraints on the characterization.

\section{B.1.4.3 Identify Practical Constraints on the Characterization}

The practical constraints on the investigation are the capability of the drill to penetrate the pad and native material, the ability to get the drill onto the sample locations, and the weather, all of which can impact the fieldwork.

\section{B.1.4.4 Define the Scale of the Decision Making}

The scale of decision making is defined as the Compressor/Blower Pad, consisting of one CAS and the access road.

\section{B.1.5 Determination of Decision Rules}

This step integrates outputs from the previous steps into a decision rule (“If..., then...”) statement. This rule describes the conditions under which possible alternative actions will be chosen.

\section{B.1.5.1 Specify the Population Parameter}

The population parameter is the maximum observed concentration of each COPC within the target population. For radiological surveys, the maximum observed concentration of each COPC will be the population parameter. If sampling is performed to support the radiological survey results, the maximum observed concentration of each COPC identified in the sample will be the population parameter. Radiological sampling results will supersede radiological survey results.

\section{B.1.5.2 Choose an Action Level}

Action levels are defined in Section B.1.3.1.4. 


\section{B.1.5.3 Measurement and Analysis Methods}

Radiological surveys and soil sampling and analysis, identified in Sections B.1.7.1 and B.1.7.2, will be used to identify the presence and location of COPCs.

The measurement and analysis methods referenced in the Industrial Sites QAPP (NNSA/NV, 2002) are capable of achieving the expected range of values to resolve the Primary Decision. The detection limit of the measurement method to be used must be less than the action level for each COPC unless otherwise specified in the CAIP (DTRA, 2005).

\section{B.1.5.4 Decision Rule}

The following decision rules are applicable to the CAU 559 investigation and will be used to guide the investigation and data evaluation:

- If laboratory results for the soil samples indicate the presence of COPCs above the PALs, then a CADD will be prepared for CAU 559 and subsequent closure will be as part of the consolidated Corrective Action Plan and CR, which will include CAU 476 (T-Tunnel Muckpile), CAU 478 (T-Tunnel Ponds), and CAU 559 (T-Tunnel Compressor/Blower Pad).

- If the laboratory results for the soil samples do not indicate the presence of COPCs above the PALs, then a CADD/CR will be prepared and submitted for CAU 559.

The PALs are defined in Section B.1.3.1.4.

\section{B.1.6 Specify Limits on the Decision Error}

Only validated analytical results (quantitative data) will be used to determine whether COPCs are present, unless otherwise stated. The baseline condition, or null hypothesis, assumed for this site is that COPCs above the action levels are present in the pad. The alternate hypothesis is that COPCs above the action levels are not present in the pad. Based on these hypotheses, two types of decision errors are possible, false positive and false negative. The CAIP was designed to minimize both types of errors.

\section{B.1.6.1 False Positive Decision Error}

The consequences of a false positive are: (1) the corrective action could be needlessly expanded to encompass a greater quantity of media than is necessary, and (2) media incorrectly judged to 
be contaminated could be treated as regulated waste rather than unregulated waste. Both of these consequences could lead to increased corrective action and waste disposal costs.

\section{B.1.6.2 False Negative Decision Error}

The consequences of a false negative are: (1) regulated contaminants might not be appropriately addressed by the corrective action, (2) contaminated media could be wrongly classified as non contaminated, and (3) contaminated media might be disposed of improperly. These consequences could result in unacceptable risks to human health and the environment and potential fines from regulatory agencies.

\section{B.1.6.3 Statistical Model}

A statistical analysis was conducted to determine the answer to two questions. The first question is, "Were sufficient samples taken to ensure a 90 percent confidence level in the mean COPC concentration?" The second question is, "Does the mean concentration exceed the regulatory threshold (RT)?”

The EPA has defined RTs for many chemicals and metals in soil. However, RTs for radionuclides in soil have not been promulgated for sites such as CAU 559, nor have they been defined for the radionuclide COPCs likely to be found at DOE, National Nuclear Security Agency Nevada Site Office (NNSA/NSO) and/or DTRA sites. Therefore, the radionuclide RTs will be the recommended screening limits in the NCRP Report No. 129 recommended screening limits for construction, commercial, industrial land-use scenarios (NCRP, 1999) scaled from 25to 15-mrem/yrdose and the generic guidelines for residual concentration of radionuclides in DOE Order 5400.5 (DOE, 1993).

If chemical COPCs are found at the site, the RT values used to calculate whether sufficient samples have been taken will be the PALs as defined in Section 3.3 of the CAIP (DTRA, 2005). For TPH-DRO, the PAL is $100 \mathrm{mg} / \mathrm{kg}$ in soil, and for RCRA-regulated contaminants, the EPA Region 9 PRGs for Industrial Soils are the PALs (EPA, 2004).

To estimate the minimum number of samples required to characterize the T-Tunnel Compressor/Blower Pad, the TPH-DRO in soil results from earlier investigations were used to provide input into equation 8 in SW-846 Chapter 9 (EPA, 1998). The TPH in soil results were used because TPH-DRO is a common contaminant on compressor pads. The number of samples 
required to ensure a 90 percent confidence level was calculated using only the samples with TPH-DRO concentrations exceeding the minimum detectable concentration.

\section{Testing for the Number of Required Samples}

The analytical data from the CAU 383 (E-Tunnel Muckpile) compressor pad characterization was used to estimate the number of samples needed to characterize the T-Tunnel Compressor/Blower Pad because there are no analytical data available from the T-Tunnel Compressor/Blower Pad on which to make a determination. After the characterization is completed, the procedure described in SW-846 Chapter 9 will again be used to confirm that sufficient samples were collected to characterize the site at the 90 percent confidence level (EPA, 1998).

\section{Calculation of the Number of Samples}

Determine the number of samples required to obtain a 90 percent confidence level for the T-Tunnel Compressor/Blower Pad using the TPH-DRO data.

$$
\mathrm{n}=\mathrm{t}_{.20}{ }^{2} \times \mathrm{s}^{2} /(\mathrm{RT}-\overline{\mathrm{x}})^{2} \quad \text { where }
$$

(Equation 1)

Required number of samples for the pad:

$\mathrm{n}=$ minimum number of samples to ensure a 90 percent confidence level in the calculated mean COPC concentration

$\mathrm{t}_{20}{ }^{2}=2.002$, the square of 1.415 , the $\mathrm{t} .20$ value for 7 degrees of freedom, 90 percent confidence level, Table 9-2, SW-846

$\mathrm{s}^{2} \quad=\quad$ variance of the TPH-DRO concentration in the positive Compressor Pad samples, $1525357.981 \mathrm{mg} / \mathrm{kg}$

$\mathrm{RT}=100 \mathrm{mg} / \mathrm{kg}$

$\overline{\mathrm{x}}=$ mean TPH-DRO concentration in the positive Compressor Pad soil samples, $864.188 \mathrm{mg} / \mathrm{kg}$.

$\mathrm{n}=\quad \mathrm{t}_{.20}{ }^{2} \times \mathrm{s}^{2} /(\mathrm{RT}-\overline{\mathrm{x}})^{2}=(2.002 \times 1525357.981) /(100-864.188)^{2}=5.23$ samples 
The number of samples required to characterize the Compressor Pad was multiplied by a factor of safety of 2 to provide additional assurance that the 90 percent confidence level would be reached.

T-Tunnel Compressor/Blower Pad = 5.23 samples x $2=10.46$ samples (round up) $=11$ samples

In addition to the calculated number of required samples, a decision performance curve graph was prepared using the same data from the previous compressor pad investigation, CAU 383. The number of samples was calculated using a simple random sampling strategy. The action level (the lower limit on the graph) was set at the PAL. The upper bound of the gray area was set at the action level plus one standard deviation of the data from the previous investigation. The graph is presented in Figure B.1-2. The decision performance curve indicates that four samples are required in sampling the T-Tunnel Compressor/Blower Pad. The results from the 90 percent confidence level calculations, described in SW-846 Chapter 9, indicate that 11 samples are required. Assuming the conservative approach, to avoid false negative errors, 11 random samples will be collected from CAU 559.

The sampling program for CAU 559 was designed to provide sufficient data to allow a statistical determination of whether enough samples were collected to adequately characterize the site. This determination will be made after the investigation using the procedures described in Chapter 9 of the EPA publication SW-846, Test Methods for Evaluating Solid Waste (EPA, 1998). The mean concentration (or activity) and standard deviation of the TPH-DRO concentration in the compressor pad soils will be used to confirm that sufficient samples were collected to characterize the site at the 90 percent confidence level (EPA, 1998).

\section{B.1.6.4 Quality Assurance/Quality Control}

Radiological survey instruments will be calibrated in accordance with the manufacturer's instructions, and periodic calibrations will be performed in accordance with approved procedures.

Quality control samples will be collected as required by established procedures. The required QC samples include:

- Trip blanks (one per sample cooler containing VOC environmental samples)

- Equipment blanks (one per sampling event for each type of decontamination procedure) 


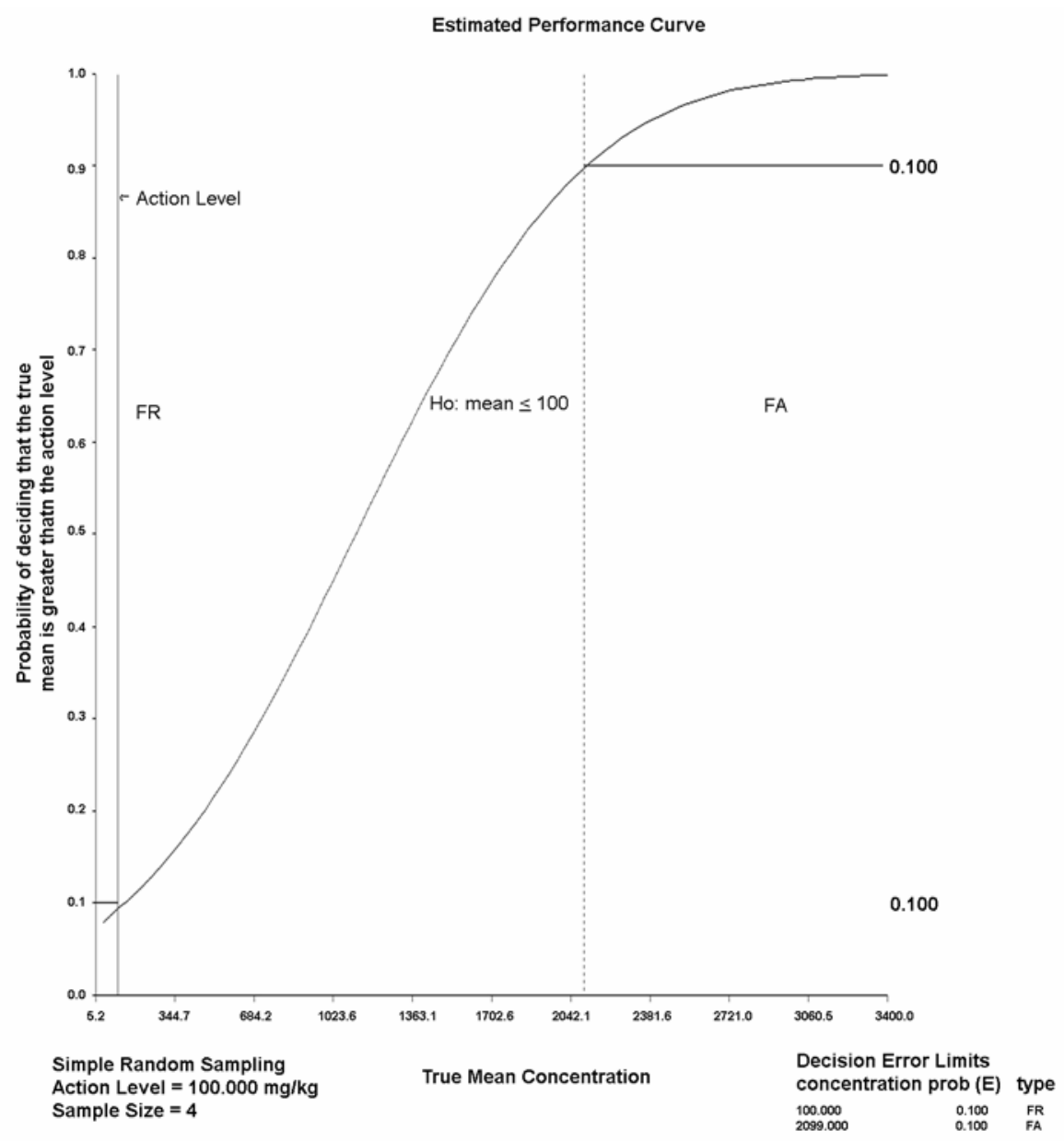

Figure B.1-2

Decision Performance Curve for TPH-DRO in the CAU 383 Blower

- Source blanks (one per source of water for decontamination and one from the water tank the first time it is filled); one sample can fill both requirements.

- Field duplicates (minimum of 1 per matrix per 20 environmental samples)

- Field blanks (minimum of 1 per 20 environmental samples); additional samples may be collected at the discretion of the Site Supervisor if conditions change.

- Matrix spike (MS)/matrix spike duplicate (MSD) (minimum of 1 per matrix per 20 environmental samples), not needed for some radioanalytical measurements (e.g., gamma spectrometry)

Additional QC samples may be submitted based on site conditions. 
The DQIs of precision, accuracy, comparability, completeness, and representativeness are defined in the Industrial Sites QAPP (NNSA/NV, 2002). Site-specific DQIs are discussed in more detail in Section 6.0 of the CAIP (DTRA, 2005).

\section{B.1.7 Optimize the Design for Data Collection}

The site characterization will consist of collecting random and possibly biased soil samples from the compressor pad and access road. The sampling program will be enhanced by conducting preliminary walkover radiological surveys to help guide the biased sampling, by determining the location and number of samples to collect. The COPCs for CAU 559 listed in Section B.1.3.1.5.2 are TPH-DRO, VOCs, SVOCs, total RCRA metals, beryllium, and radionuclides. All environmental samples will be analyzed for these parameters with the exception of the background samples, which were analyzed for radionuclides and RCRA metals only (CAU 476 T-Tunnel Muckpile background samples).

\section{B.1.7.1 Radiological Survey Methodologies and Instruments}

Radiological surveys will be conducted at CAU 559 to define the presence and lateral extent of radiological contaminants.

Walkover surveys using hand-held instruments were performed at CAU 559. Hand-held radiological survey instruments such as the NE Technology Electra, Eberline E-600, TSA-PRM-470B, and Bicron mRem, or equivalent were used.

Additional equipment and software used in the radiological data collection and processing will include a Trimble Global Positioning System (GPS) receiver and associated laptop computers used to log and process the walkover radiological data. The mapping program Surfer will be used to plot data on site maps.

\section{B.1.7.2 Intrusive Investigation}

Intrusive investigations will be conducted at CAU 559 to determine whether COPCs are present. Samples will be collected from predetermined random locations. Selection of biased locations will be based on the results of the radiological surveys, a review of the operational history, and visual inspection of the CAU. 
Borehole and sampling locations on the pad (Figure B.1-3 and Table B.1-6) were identified using a simple random sampling strategy. Three additional locations were identified to be used in the event that not all of the identified locations can be utilized.

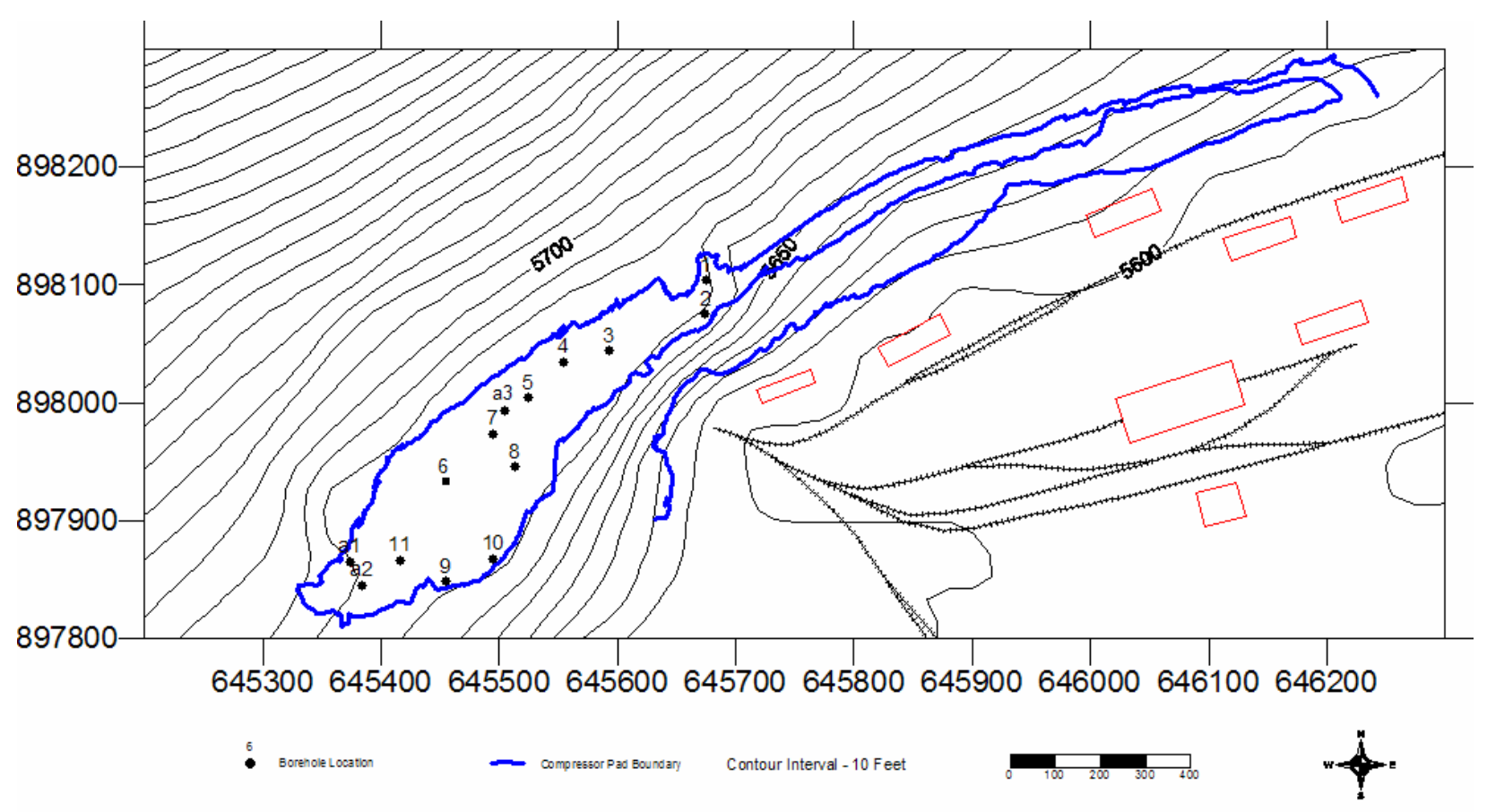

Figure B.1-3

CAU 559 Proposed Random Borehole Locations 
Table B.1-6

Coordinates for Random Intrusive Investigation Locations

\begin{tabular}{|c|c|c||}
\hline \multicolumn{1}{|c|}{ Sampling Locations } \\
\hline \hline Location & Easting & Northing \\
\hline 1 & 645674.859 & 898104.099 \\
\hline 2 & 645674.023 & 898075.089 \\
\hline 3 & 645592.969 & 898044.408 \\
\hline 4 & 645553.935 & 898034.858 \\
\hline 5 & 645524.091 & 898004.177 \\
\hline 6 & 645461.301 & 897933.026 \\
\hline 7 & 645494.248 & 897973.854 \\
\hline 8 & 645513.109 & 897945.442 \\
\hline 9 & 645454.020 & 897848.504 \\
\hline 10 & 645494.726 & 897867.844 \\
\hline 11 & 645415.462 & 897866.531 \\
\hline Alternate 1 (a1) & 645373.801 & 897865.218 \\
\hline Alternate 2 (a2) & 645382.993 & 897845.520 \\
\hline \hline
\end{tabular}

Rotosonic drilling will be the primary tool used to collect the soil samples for laboratory analysis to determine whether COPCs are present. Boreholes will be drilled $5 \mathrm{ft}$ into the native material if it is alluvium, $2 \mathrm{ft}$ if it is bedrock, or until refusal. If the bottom interval of the hole exceeds the field-screening levels, the hole will be continued at 2-ft intervals until there are two consecutive clean intervals or until drill refusal. If a drilling location cannot be accessed by the drill rig, hand augers or similar hand tools will be used to collect the soil samples.

The sampling strategies for the site are shown in Figure B.1-4. 


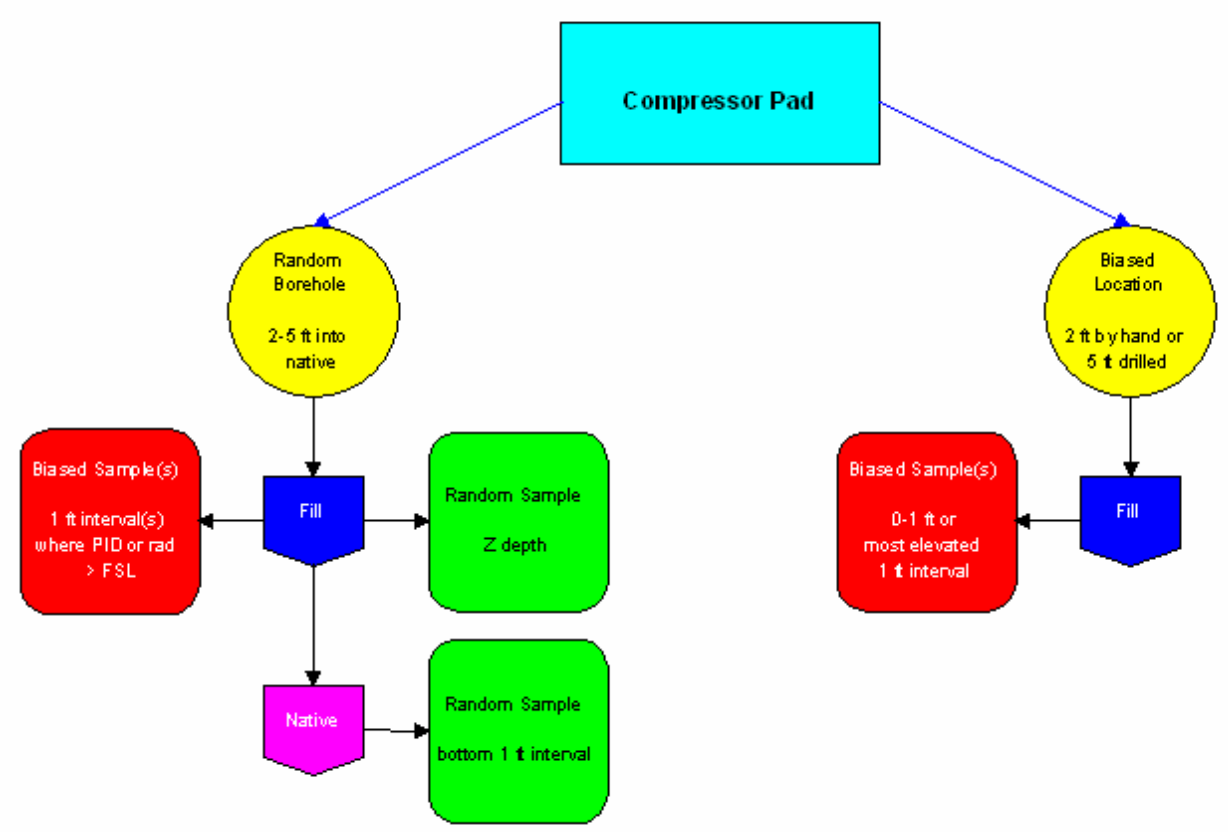

Figure B.1-4

CAU 559 Sampling Strategy 


\section{B.2.0 References}

Black, S.C., and Y.E. Townsend. 1996. U.S. Department of Energy, Nevada Operations Office Environmental Data Report for the Nevada Test Site - 1994. Las Vegas, NV.

DOE see U.S. Department of Energy.

DOE/NV, see U.S. Department of Energy, Nevada Operations Office.

DTRA, see Defense Threat Reduction Agency.

Defense Threat Reduction Agency. 2005. Corrective Action Investigation Plan for Corrective Action Unit 559: T-Tunnel Compressor/Blower Pad, Nevada Test Site, Rev. 0. Las Vegas, NV.

EPA, see U.S. Environmental Protection Agency.

McArthur, R.D., and F.L. Miller, Jr. 1989. Offsite Radiation Exposure Review Project (ORERP), Phase II Soils Programs, DOE/NV/10384-23. Las Vegas, NV: Desert Research Institute.

Moore, J., Science Applications International Corporation. 1999. Memorandum to M. Todd (SAIC) entitled, "Background Concentrations for NTS and TTR Soil Samples.” Las Vegas, NV.

NAC, see Nevada Administrative Code.

NBMG, see Nevada Bureau of Mines and Geology.

NCRP, see National Council on Radiation Protection and Measurements.

NNSA/NV, see U.S. Department of Energy, National Nuclear Security Administration Nevada Operations Office.

National Council on Radiation Protection and Measurements. 1999. Recommended Screening Limits for Contaminated Surface Soil and Review of Factors Relevant to Site-Specific Studies. NCRP Report No. 129. National Council on Radiation Protection and Measurements, Bethesda MD.

Nevada Administrative Code. 2002. NAC 445A.2272, “Contamination of Soils: Establishment of Action Levels" Carson City, NV.

Nevada Bureau of Mines and Geology. 1998. Mineral and Energy Resource Assessment of the Nellis Air Force Range, Open File Report 98-1. Las Vegas, NV.

U.S. Department of Energy. 1993. "Radiation Protection of the Public and Environment.” DOE Order 5400.5 Change 2. January 7. 
U.S. Department of Energy, Nevada Operations Office. 1996a. Final Environmental Impact Statement for the Nevada Test Site and Off-Site Locations in the State of Nevada, Volume I, Chapters 1-9, DOE/EIS 0243. Las Vegas, NV.

U.S. Department of Energy, Nevada Operations Office. 1996b. Radiological Effluents Released from U.S. Continental Tests through 1992, DOE/NV--317, Rev. 3. Las Vegas, NV.

U.S. Department of Energy, Nevada Operations Office. 1998. Nevada Test Site Resource Management Plan, DOE/NV--18. Las Vegas, NV.

U.S. Department of Energy, National Nuclear Security Administration Nevada Operations Office. 2002. Industrial Sites Quality Assurance Project Plan, Nevada Test Site, Nevada, NNSA/NV--372, Rev. 3. Las Vegas, NV.

US Ecology and Atlan-Tech, Inc. 1991. Environmental Monitoring Report for the Proposed Ward Valley, California, Low-Level Radioactive Waste (LLRW) Facility, Vols. 1 and 2, Version 2. Rosewell, GA: California Department of Health, Environmental Management Branch.

U.S. Environmental Protection Agency. 1998. Test Methods for Evaluating Solid Waste, Physical/Chemical Methods, SW-846, 3rd Edition, CD-ROM PB97-501928GEI. Washington, DC.

U.S. Environmental Protection Agency. 2004. Region 9 Preliminary Remediation Goals (PRGs). San Francisco, CA. 


\section{Appendix C}

\section{Data Assessment}




\section{C.1.0 Data Assessment}

The DQA process is the scientific evaluation of the investigation results to determine whether the DQO criteria established in the CAU 559 CAIP were met and whether the DQO decisions can be supported at the desired level of confidence. The DQO process ensures that the right type, quality, and quantity of data will be available to support the resolution of the decisions at an appropriate level of confidence. Using both the DQO and DQA processes helps to ensure that the DQO decisions are sound and defensible, and that the 90 percent level of confidence agreed to in the CAIP was achieved.

The DQA involves five steps that begin with a review of the DQOs and end with an answer to the DQO decisions. The five steps are briefly summarized below.

Step 1: Review the DQOs and Sampling Design - Review the DQO process to provide context for analyzing the data. State the primary statistical hypotheses; confirm the limits on the decision errors for committing false rejection (Type I) or false acceptance (Type II) decision errors; and review any special features, potential problems, or deviations to the sampling design.

Step 2: Conduct a Preliminary Data Review - The preliminary data review involves reviewing QA reports and inspecting the data both numerically and graphically, validating and verifying the data to ensure that the measurement systems performed in accordance with the criteria specified, and using the validated data to determine whether the quality of the data is satisfactory.

Step 3: Select the Test - Select the test based on the population of interest, population parameter, and the hypotheses. Identify the key underlying assumptions that could cause a change in one of the DQO decisions.

Step 4: Verify the Assumptions - Perform tests of assumptions. If data are missing or are censored, determine the impact on the DQO decision error.

Step 5: Draw Conclusions from the Data - Perform the calculations required for the test.

\section{C.1.1 Review the DQOs and Sampling Design}

This section contains a review of the DQO process presented in the CAU 559 CAIP (DTRA, 2005) and Appendix B of this document. The DQO decisions are presented with the DQO provisions for limiting false negative or false positive decision errors. Special features, potential problems, or any deviations from the sampling design are also presented. 


\section{C.1.1.1 Review DQOS}

The decision statement as presented in the CAU 559 CAIP is: “Are there concentrations of COPCs present in the T-Tunnel Compressor/Blower Pad that exceed the action levels and, if so, do they pose a threat to human health and/or the environment?”

\section{DQO Provisions To Limit False Negative Decision Error}

A false negative decision error (where consequences are more severe) was controlled by meeting the following criteria:

1. Having a high degree of confidence that the combination of random and biased sampling strategies will identify COCs if present in the CASs.

2. Having a high degree of confidence that analyses conducted will be sufficient to detect any COCs present in the samples.

3. Having a high degree of confidence that the data are of sufficient quality and completeness.

\section{Criterion 1:}

The following methods (stipulated in the CAU 559 DQOs [DTRA, 2005] and agree to by NDEP) were used in selecting the sample locations:

- Random locations to collect soil samples from the pad.

- $\quad$ Biased locations based on professional judgment and site knowledge to collect soil samples from the pad and access road.

This provides a high degree of confidence that sampling will detect any COCs that may be present.

\section{Criterion 2:}

All samples were analyzed using the analytical methods listed in Table 3-1 of the CAIP. Table C.1-1 provides a reconciliation of environmental samples analyzed to the planned analytical program. Samples were analyzed for all of the analytical methods specified in the CAIP (DTRA, 2005). 
Table C.1-1

CAU 559 Number of Soil Samples Submitted per Analyte

\begin{tabular}{|c|c|c|c|c|c|c|c|c|c|}
\hline & \multicolumn{9}{|c|}{ Analytes } \\
\hline & 仓̊ & 仓̊ & $\begin{array}{l}\mathscr{n} \\
\text { O্口 }\end{array}$ & 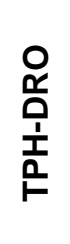 & $\begin{array}{l}\text { O } \\
\frac{1}{0} \\
\frac{1}{1} \\
\frac{1}{0} \\
F\end{array}$ & $\frac{\frac{\omega}{\pi}}{\frac{0}{0}}$ & 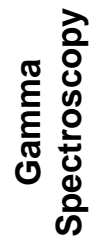 & 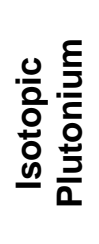 & 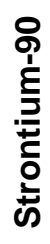 \\
\hline Pad Soil & 13 & 13 & 13 & 13 & 13 & 13 & 13 & 13 & 13 \\
\hline Native Soil & 10 & 10 & 10 & 10 & 10 & 10 & 10 & 10 & 10 \\
\hline Access Road & 6 & 6 & 6 & 6 & 6 & 6 & 6 & 6 & 6 \\
\hline Background & 0 & 0 & 0 & 0 & 0 & 3 & 3 & 0 & 0 \\
\hline
\end{tabular}

Sample results were assessed against the DQI of sensitivity as defined in the Industrial Sites QAPP (NNSA/NV, 2002). The sensitivity acceptance criteria defined in the CAIP is that analytical detection limits will be less than the corresponding action level. This goal was not achieved for the chemical analyses listed in Table C.1-2. All radiological analytes met the sensitivity goal. Results not meeting the sensitivity goal were not used in making DQO decisions and will therefore be considered as rejected data.

Table C.1-2

Chemical Analytes Failing Sensitivity Criteria for CAU 559

\begin{tabular}{|c|c|c|c|c||}
\hline Sample Number & Parameter & $\begin{array}{c}\text { Result } \\
(\boldsymbol{\mu g} / \mathbf{k g})\end{array}$ & $\begin{array}{c}\text { Detection Limit } \\
(\boldsymbol{\mu g} / \mathbf{k g})\end{array}$ & $\begin{array}{c}\text { 2004 Industrial } \\
\text { PRG }(\boldsymbol{\mu g} / \mathbf{k g})\end{array}$ \\
\hline \hline 559BH0105.5 & Benzo(a)pyrene & 260 & 260 & 210 \\
\hline 559BH0105.5 & Dibenzo(a,h)anthracene & 260 & 260 & 210 \\
\hline
\end{tabular}

PRG = Preliminary remediation goal

$\mu \mathrm{g} / \mathrm{kg}=$ Micrograms per kilogram

\section{Criterion 3:}

To satisfy the third criterion, the entire dataset, as well as individual sample results, were assessed against the acceptance criteria for the DQIs of precision, accuracy, comparability, completeness, and representativeness, as defined in the Industrial Sites QAPP (NNSA/NV, 2002). The DQI acceptance criteria for precision and accuracy are defined in Table 3-1 of the CAIP (DTRA, 2005). The acceptance criteria for comparability, completeness, and representativeness are not specified in the CAIP. As presented in the following sections, these goals were met for each DQI except as noted. 


\section{$\underline{\text { Precision }}$}

The duplicate precision is evaluated using the relative percent difference (RPD) or normalized difference. For the purpose of determining the data precision of chemical analyses, the RPD between duplicate analyses was calculated. For radionuclides, the RPD was not calculated unless both the sample and its duplicate had a concentration of the target radionuclide exceeding five times their minimum detectable concentration. Otherwise, radionuclide duplicate results were evaluated using the normalized difference. Table C.1-3 provides the results for all constituents that were qualified for precision. No radionuclides were qualified for precision.

Table C.1-3

Precision Measurements

\begin{tabular}{|c|c|c|c|c|c||}
\hline \hline Parameter & CAS Number & $\begin{array}{c}\text { User Test } \\
\text { Panel }\end{array}$ & $\begin{array}{c}\text { Number of } \\
\text { Analyses } \\
\text { Qualified }\end{array}$ & $\begin{array}{c}\text { Number of } \\
\text { Measurements } \\
\text { Performed }\end{array}$ & $\begin{array}{c}\text { Percent } \\
\text { within Criteria }\end{array}$ \\
\hline \hline Barium & $7440-39-3$ & EPA 6010B & 12 & 29 & 58.6 \\
\hline
\end{tabular}

CAS $=$ Chemical Abstracts Service

EPA = U.S. Environmental Protection Agency, SW-846 methods (EPA, 1999 and 2004)

As shown in Table C.1-3, the precision rate for barium was below the acceptance criterion of 80 percent. The precision rate for all of the constituents not listed in the table is 100 percent. The precision goal for barium is greater than 80 percent within criteria. The highest barium concentration $(4,350 \mathrm{mg} / \mathrm{kg})$ is 15 times less than the FAL $(67,000 \mathrm{mg} / \mathrm{kg})$, so the chance of having a false negative is very small; therefore, the barium results that were qualified for precision can be used to support DQO decisions. Because all of the other constituents exceed the acceptance criteria for precision, the dataset is determined to be acceptable for the DQI of precision.

\section{Accuracy}

For the purpose of determining data accuracy of sample analyses, environmental soil samples were evaluated and incorporated into the accuracy calculation. The metals results qualified for accuracy were associated with low percent recovery for the MS/MSD samples and could potentially be reported at concentrations lower than actual concentration. Table C.1-4 provides the evaluation results for the constituents qualified for accuracy. 
Table C.1-4

Accuracy Measurements

\begin{tabular}{|c|c|c|c|c|c||}
\hline Parameter & $\begin{array}{c}\text { CAS } \\
\text { Number }\end{array}$ & $\begin{array}{c}\text { User Test } \\
\text { Panel }\end{array}$ & $\begin{array}{c}\text { Number of } \\
\text { Analyses } \\
\text { Qualified }\end{array}$ & $\begin{array}{c}\text { Number of } \\
\text { Measurements } \\
\text { Performed }\end{array}$ & $\begin{array}{c}\text { Percent } \\
\text { within } \\
\text { Criteria }\end{array}$ \\
\hline \hline TPH-DRO & $68334-30-5$ & EPA8015 & 2 & 29 & 93.1 \\
\hline Arsenic & $7440-38-2$ & EPA6010 & 17 & 29 & 41.4 \\
\hline Barium & $7440-39-3$ & EPA6010 & 17 & 29 & 41.4 \\
\hline Cadmium & $7440-43-9$ & EPA6010 & 17 & 29 & 41.4 \\
\hline Lead & $7439-92-1$ & EPA6010 & 17 & 29 & 41.4 \\
\hline Selenium & $7782-49-2$ & EPA6010 & 17 & 29 & 41.4 \\
\hline Silver & $7440-22-4$ & EPA6010 & 17 & 29 & 41.4 \\
\hline
\end{tabular}

CAS $=$ Chemical Abstracts Service

The metals concentrations that were qualified for accuracy had reported concentrations that were 4.5 (for arsenic) to 4,212 (for barium) times less than the PAL, which makes the likelihood of a false negative having an actual concentration above the PAL very small; therefore, these data can still be used to support the DQO decisions. Of the analytes qualified, only TPH-DRO was considered to be a possible contaminant for this site. As the accuracy rate for all of the other constituents exceeds the acceptance criteria, the dataset is determined to be acceptable for the DQI of accuracy.

\section{$\underline{\text { Representativeness }}$}

The DQO process as identified in Section 3.0 of the CAU 559 CAIP (DTRA, 2005) was used to address sampling and analytical requirements for CAU 559. During this process, appropriate locations were selected that enabled the samples collected to be representative of the population parameters identified in the DQO (random locations and biased locations that were most likely to encounter contamination). The sampling locations identified in the Criterion 1 discussion meet these criteria. Therefore, the analytical data acquired during the CAU 559 CAI are considered to be representative of the population parameters.

\section{Comparability}

Field sampling, as described in the CAU 559 CAIP (DTRA, 2005), was performed and documented in accordance with approved procedures that are comparable to standard industry practices. Approved analytical methods and procedures were used to analyze, report, and validate the data. These are comparable to other methods used not only in industry and government practices, but most importantly are comparable to other investigations conducted at the NTS. Therefore, project datasets are considered comparable to other datasets generated 
using these same standardized DOE procedures, thereby meeting the DQO requirements. Also, standard, approved field and analytical methods ensure that data were appropriate for comparison to the investigation action levels specified in the CAIP (DTRA, 2005).

\section{Completeness}

The CAU 559 CAIP did not define criteria for completeness; therefore, the criteria of 80 percent of CAS-specific non-critical analytes identified in the CAIP having valid results and 100 percent of critical analytes having valid results will be used for the CAU 559 evaluation. Also, the dataset must be sufficiently complete to be able to support the DQO decisions. Critical analytes for CAU 559 were not defined, so the COCs identified from other investigated NTS muckpiles (arsenic, lead, TPH-DRO, Pu-239, Cs-137, and Co-60) have been defined as the critical analytes for CAU 559.

Rejected data (either qualified as rejected or data that failed the criterion of sensitivity) were not used in the resolution of DQO decisions and are not counted toward meeting the completeness acceptance criterion. The completeness for all chemical and radiological data was 100 percent; therefore, the dataset is considered complete for purposes of supporting the DQO decisions.

\section{DQO Provisions To Limit False Positive Decision Error}

The false positive decision error was controlled by assessing the potential for false positive analytical results. Quality Assurance/QC samples such as field blanks, trip blanks, laboratory control samples, and method blanks were used to determine whether a false positive analytical result may have occurred. Of the 17 QA/QC samples submitted, no false positive analytical results were detected.

Proper decontamination of sampling equipment and the use of certified clean sampling equipment and containers minimized the potential for cross contamination that could lead to a false positive analytical result.

\section{C.1.1.2 Sampling Design}

The CAIP (DTRA, 2005) made the following commitments for sampling:

1. Random sampling was conducted on the Compressor/Blower Pad.

Result: The 11 random locations identified were drilled and sampled. 
2. Biased locations were identified and drilled to investigate the access road and to investigate hot spots identified in the radiological walkover survey.

Result: Six biased locations were identified and sampled to investigate the road, and two locations were identified to investigate elevated radiological readings on the pad.

\section{C.1.2 Conduct a Preliminary Data Review}

A preliminary data review was conducted by reviewing QA reports and inspecting the data. The contract analytical laboratories generate a QA non-conformance report when data quality does not meet contractual requirements. All data received from the analytical laboratories met contractual requirements, and no QA non-conformance reports were generated. Data were validated and verified to ensure that the measurement systems performed in accordance with the criteria specified. The validated dataset quality was found to be satisfactory.

\section{C.1.3 Select the Test}

The CAIP (DTRA, 2005) committed to using the procedure described in Chapter 9 of the EPA SW-846 Method (EPA, 1999) to answer two questions: 1) Were enough samples collected to ensure a 90 percent confidence level in the mean COPC concentration and 2) Does the mean concentration exceed the regulatory threshold?

Because of the change in closure strategy agreed to by NDEP, DTRA, and NNSA/NSO, the regulatory threshold is now the risk-based FAL instead of the PALs discussed in the CAIP. Comparing the average concentration of the most prevalent contaminants to their PAL and, if they exceed the PAL, comparing them to their respective FALs will also be used to help answer the questions.

\section{C.1.4 SW-846 Evaluation}

To answer the first question, equation (8) of Table 9-1 in SW-846 was used. To answer the second question, equation (6) of Table 9-1 in SW-846 was used (EPA, 1999). Only results from random samples were used for this evaluation. These questions were answered for the critical analytes Cs-137, TPH-DRO as they were the only critical analytes for which there were sufficient detections. 
Question 1: “Were enough samples collected?” is answered by solving equation (8) of Table 9-1 in SW-846 for each analyte.

$$
\mathrm{n}=\mathrm{t}_{.20}{ }^{2} \times \mathrm{s}^{2} /(\mathrm{RT}-\overline{\mathrm{x}})^{2} \quad \text { where }
$$

(Equation 1)

$\mathrm{n} \quad=\quad$ minimum number of samples to ensure a 90 percent confidence level

$\mathrm{t}_{20}{ }^{2}=$ the square of the " $\mathrm{t}$ " value in Table 9-2, SW-846 for a one-tailed 90 percent confidence interval

$\mathrm{s}^{2}=\quad$ variance in the concentration measured in the samples collected during characterization

RT = regulatory threshold and is set to the limiting PRG established by the EPA for the COPC for the industrial land use. For TPH, the RT is $100 \mathrm{mg} / \mathrm{kg}$. For radionuclides, it is the U.S. Nuclear Regulatory Commission and National Council on Radiation Protection and Measurements screening levels

$$
\bar{x}=\text { the mean concentration of the COPC in the collected samples. }
$$

Question 2: "Does the mean concentration exceed the regulatory threshold?" is answered by solving equation (6) of Table 9-1 in SW-846 for each analyte.

$$
\mathrm{CI}=\overline{\mathrm{x}}+/-\left(\mathrm{t}_{.20} \times\left(\frac{\mathrm{s}}{\sqrt{n}}\right)\right) \quad \text { where }
$$

(Equation 2)

$\mathrm{CI}=$ confidence interval

$\bar{x}=\quad$ the mean concentration of the COPC in the collected samples

$\mathrm{n} \quad=\quad$ number of samples collected

t.20 = the "t" value in Table 9-2, SW-846 for a one-tailed 90 percent confidence interval and the appropriate degrees of freedom

$\mathrm{s}_{\overline{\mathrm{x}}} \quad=\quad$ variance in the concentration measured in the samples collected during characterization

The values used for the calculations and the results are presented in Table C.1-5. 
Table C.1-5

SW-846 Evaluation of the Number of Samples and Comparison of $90 \%$ Confidence Level with the PAL

\begin{tabular}{||l|c|c|}
\hline \multicolumn{1}{|c|}{ Variable } & Cs-137 & TPH-DRO \\
\hline$T_{\cdot 20}$ & 1.372 & 1.372 \\
\hline$T_{\cdot 20}{ }^{2}$ & 1.882 & 1.882 \\
\hline $\mathrm{S}^{2}$ & 2.249 & $8.477 \mathrm{E}+04$ \\
\hline $\mathrm{RT}$ & $12.2 \mathrm{pCi} / \mathrm{g}$ & $100 \mathrm{mg} / \mathrm{kg}$ \\
\hline Avg $\bar{x}$ & $1.149 \mathrm{pCi} / \mathrm{g}$ & $165.782 \mathrm{mg} / \mathrm{kg}$ \\
\hline $\mathrm{n}$ collected & 11 & 11 \\
\hline $\mathrm{n}$ needed & $<1$ & 37 \\
\hline Upper Confidence Interval & 1.769 & 286.226 \\
\hline Upper Confidence>RT & No & Yes \\
\hline
\end{tabular}

Based on the results of the calculations, an adequate number of samples were collected to meet the 90 percent confidence level for characterization of the site for Cs-137 but not enough to fully characterize the site with respect to TPH-DRO. The PCB 1260 results were not used because they are all from biased samples. In comparing the 90 percent confidence level to the RT, the confidence level for Cs-137 is below the RT. The confidence level for TPH-DRO exceeds the RT by 4.5 times for the Compressor/Blower Pad. Because the confidence level for TPH-DRO exceeds the RT, TPH-DRO will be moved to a Tier 2 analysis to determine whether it poses a threat to human health or the environment. Because not enough samples were collected to achieve the 90 percent confidence level for site characterization with respect to TPH-DRO the site will be assumed to be contaminated with TPH-DRO and closed accordingly.

\section{C.1.5 Verify the Assumptions}

The results of the investigation support the assumptions identified in the CAU 559 DQOs and in Table C.1-6. 
Table C.1-6

Date: November 2006

Page C-10 of C-12

\section{Key Assumptions}

\begin{tabular}{|c|c|}
\hline \multirow[t]{2}{*}{ Exposure Scenario } & $\begin{array}{l}\text { Exposure to contaminants is limited to industrial site workers, } \\
\text { construction/remediation workers, and military personnel conducting training. } \\
\text { Exposure could occur through ingestion, inhalation, external exposure, or } \\
\text { dermal contact. }\end{array}$ \\
\hline & $\begin{array}{l}\text { The investigation did not reveal any potential exposures that were not identified } \\
\text { in the conceptual site model (CSM). }\end{array}$ \\
\hline \multirow[t]{2}{*}{ Affected Media } & $\begin{array}{l}\text { Surface and subsurface soils in and below the Compressor/Blower Pad. } \\
\text { Contamination of perched, deep, and regional groundwater is not a concern. }\end{array}$ \\
\hline & $\begin{array}{l}\text { The investigation results did not identify any affected media that were not } \\
\text { identified in the CSM. }\end{array}$ \\
\hline \multirow[t]{2}{*}{$\begin{array}{l}\text { Location of Contamination } \\
\text { Release Points }\end{array}$} & $\begin{array}{l}\text { The pad may contain small volumes of RCRA-regulated constituents in addition } \\
\text { to radiological constituents. }\end{array}$ \\
\hline & $\begin{array}{l}\text { The investigation results confirmed this and did not reveal any potential } \\
\text { releases off the pad. }\end{array}$ \\
\hline \multirow[t]{2}{*}{ Transport Mechanisms } & $\begin{array}{l}\text { Contamination may migrate through the pad into the native material as a result } \\
\text { of rainwater infiltration. }\end{array}$ \\
\hline & $\begin{array}{l}\text { Low levels of TPH-DRO were found in four native soil samples from under the } \\
\text { pad and in three of the biased samples from the road downslope from the pad } \\
\text { indicating that rainwater may be transporting the TPH-DRO. }\end{array}$ \\
\hline \multirow[t]{2}{*}{ Preferential Pathways } & Percolation of precipitation through the soils of the pad. \\
\hline & $\begin{array}{l}\text { Low levels of TPH-DRO were found in four native soil samples from under the } \\
\text { pad. }\end{array}$ \\
\hline \multirow[t]{2}{*}{$\begin{array}{l}\text { Lateral and Vertical Extent of } \\
\text { Contamination }\end{array}$} & $\begin{array}{l}\text { Contamination could be locally significant, but vertical infiltration of } \\
\text { contaminants is probably limited to less than } 5 \text { feet. }\end{array}$ \\
\hline & $\begin{array}{l}\text { This was confirmed by the investigation for all contaminants except TPH-DRO, } \\
\text { which was found under the pad and downgradient from it on the access road. }\end{array}$ \\
\hline Groundwater Impacts & There are no groundwater impacts. \\
\hline \multirow[t]{2}{*}{ Future Land Use } & Nonresidential, zoned for nuclear and high explosives tests. \\
\hline & $\begin{array}{l}\text { The investigation results did not reveal any future land uses other than those } \\
\text { identified in the CSM. }\end{array}$ \\
\hline
\end{tabular}

\section{C.1.6 Results}

This section resolves the DQO decision for CAU 559. 


\section{C.1.6.1 Decision Rules for CAU 559}

Decision Rule: If laboratory results for the soil samples indicate the presence of COPCs above the PALs, then a CADD will be prepared for CAU 559 and subsequent closure will be as part of the consolidated Corrective Action Plan and CR, which will include CAU 476 (T-Tunnel Muckpile), CAU 478 (T-Tunnel Ponds), and CAU 559 (T-Tunnel Compressor/Blower Pad).

Result: Representatives from DTRA and NDEP came to an agreement that a risk-based approach would be used for characterizing the Compressor/Blower Pad. Using the risk-based approach for limited access occasional use scenario, FALs were not exceeded. However; based on the SW-846 calculations, not enough samples were collected to characterize the site to the 90 percent confidence level for TPH-DRO and the average concentration exceeded the regulatory threshold. Therefore, the Compressor/Blower Pad is assumed to be contaminated with TPHDRO and will be closed accordingly.

Decision Rule: If laboratory results for the soil samples do not indicate the presence of COPCs above the PALs, then a CADD or CADD/CR will be prepared.

Result: The PALS were exceeded but only for TPH-DRO which a Tier 2 analysis showed to not present a risk to human health or the environment. Therefore, a CADD/CR will be prepared that will propose use restrictions for controlling access to the site. 


\section{C.2.0 References}

DTRA, see Defense Threat Reduction Agency.

Defense Threat Reduction Agency. 2005. Corrective Action Investigation Plan for Corrective Action Unit 559: T-Tunnel Compressor/Blower Pad, Nevada Test Site. Rev. 0. Las Vegas, NV.

EPA, see U.S. Environmental Protection Agency.

NNSA/NV, see U.S. Department of Energy, National Nuclear Security Administration Nevada Operations Office.

U.S. Department of Energy, National Nuclear Security Administration, Nevada Operations Office. 2002. Industrial Sites Quality Assurance Project Plan, Nevada Test Site, Nevada, DOE/NV--372, Rev. 3. Las Vegas, NV.

U.S. Environmental Protection Agency. 1999. Test Methods for Evaluating Solid Waste, Physical/Chemical Methods, SW-846. $3^{\text {rd }}$ Edition. Washington, DC.

U.S. Environmental Protection Agency. 2004. Region 9 Preliminary Remediation Goals (PRGs). San Francisco, CA. 


\section{Appendix D \\ Risk Assessment for CAU 559}




\section{D.1.0 Risk-Based Corrective Action Process}

This section contains documentation of the ASTM Method E 1739-95 (ASTM, 1995) risk-based corrective action process as applied to CAU 559. The ASTM Method E 1739-95 defines three tiers or levels in evaluating DQO decisions involving increasingly more sophisticated analyses.

- $\quad$ Tier 1 - Sample results from source areas (highest concentrations) compared to the PALs based on generic (non-site-specific) conditions.

- $\quad$ Tier 2 - Sample results from exposure points compared to SSTLs calculated using site-specific inputs and Tier I formulas (from the ASTM procedure).

- $\quad$ Tier 3 - Sample results from exposure points compared to SSTLs and points of compliance calculated using chemical fate/transport and probabilistic modeling.

The risk based corrective action decision process stipulated in ASTM Method E 1739-95 is summarized in Figure D.1-1.

\section{D.1.1 Scenario}

Corrective Action Unit 559 (T-Tunnel Compressor/Blower Pad) consists of one CAS.

- CAS 12-25-13, Oil Stained Soil and Concrete

In addition to this CAS, the access road from the T-Tunnel Muckpile to the Compressor/Blower Pad was characterized.

The Compressor/Blower Pad is associated with the T-Tunnel, which was mined into bedded ash flow tuff under Aqueduct Mesa. The tunnel was used for six nuclear tests between 1970 and 1987. The Compressor/Blower Pad is constructed of native alluvium and fill overlying the tuffs of the Calico Hills Formation. The surface elevation at the pad is 5,670 ft above mean sea level. Groundwater is 800 to $900 \mathrm{ft}$ below ground surface (USGS/DOE, 2004). The pad was constructed in the hillside above the tunnel portal. The pad is approximately $150 \mathrm{ft}$ across at its widest point and $375 \mathrm{ft}$ long in a southwest-northeast direction. The thickness of the pad ranges from less than $1 \mathrm{ft}$ to approximately $10 \mathrm{ft}$. Any surface runoff generally flows down the access road to the muckpile. 


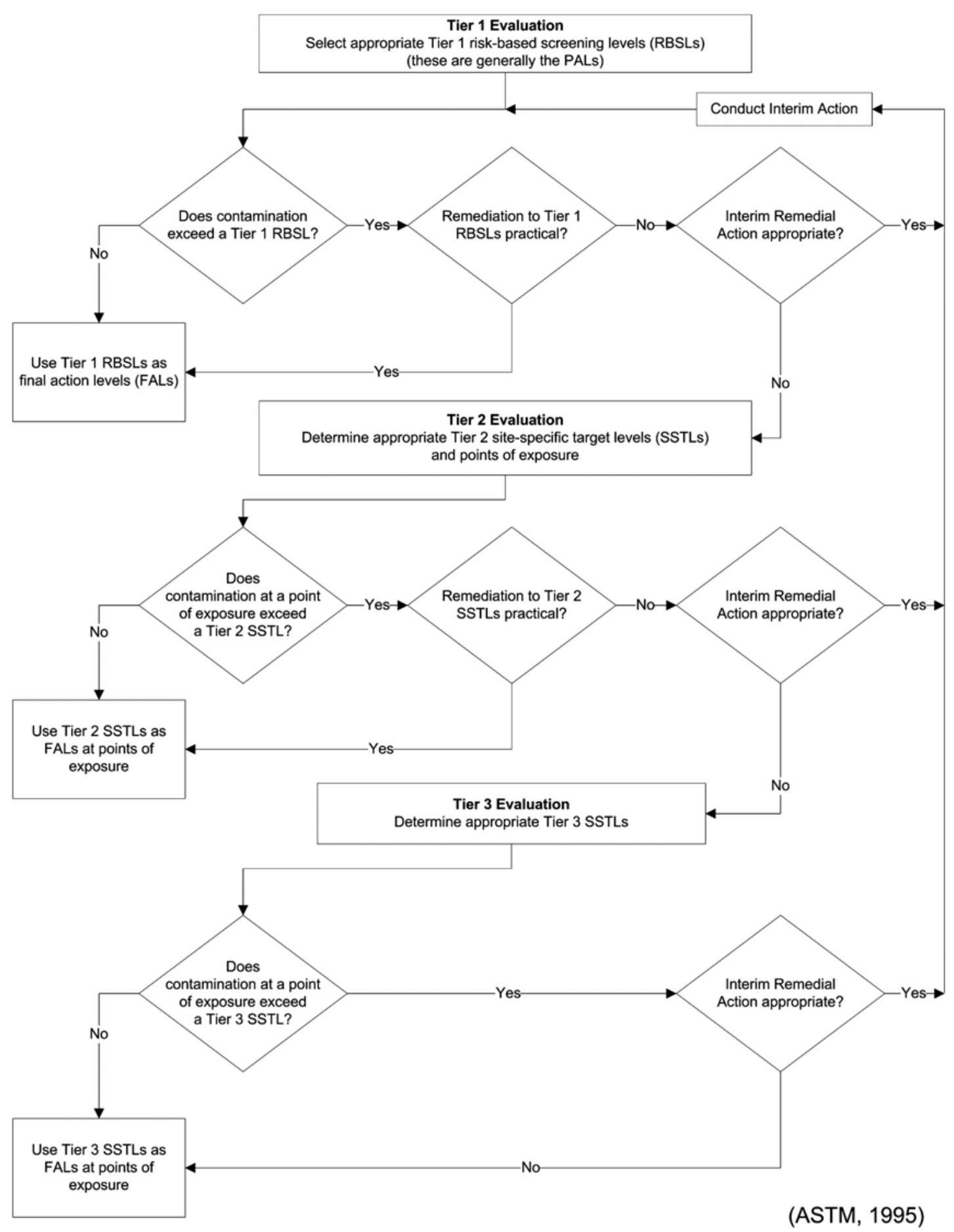

Figure D.1-1

ASTM Method E 1739-95 Risk-Based Corrective Action Decision Process 


\section{D.1.2 Site Assessment}

The CAI at CAU 559 involved soil sampling using rotosonic drilling techniques or hand tools. The investigation results identified TPH-DRO and radiological COCs that exceeded the PALs as defined in the CAIP (DTRA, 2005). The maximum concentration of the COCs identified and their corresponding PALs (Tier 1 comparison) are presented in Tables D.1-1 (chemical results) and D.1-2 (radiological results).

Table D.1-1

Maximum Reported Chemical Values for Tier 1 Comparison

\begin{tabular}{|c|c|c|c|c|}
\hline Contaminant & CAS Number & Sample No. & $\begin{array}{c}\text { Result } \\
\text { (mg/kg) }\end{array}$ & $\begin{array}{c}\text { PAL } \\
\text { (mg/kg) }\end{array}$ \\
\hline \hline Acetone & $67-64-1$ & $559 B B 0800.5$ & 0.016 & $54,000^{\mathrm{a}}$ \\
\hline Arsenic & $7440-38-2$ & $559 \mathrm{BH} 0500.5$ & 6.19 & $23^{\mathrm{b}}$ \\
\hline Barium & $7440-39-3$ & $559 \mathrm{BB} 0300.5$ & 4,350 & $67,000^{\mathrm{a}}$ \\
\hline Beryllium & $7440-41-7$ & $559 \mathrm{BH} 1005.5$ & 1.49 & $1,900^{\mathrm{a}}$ \\
\hline Bis(2-ethylhexyl)phthalate & $117-81-7$ & $559 \mathrm{BB} 0800.5$ & 1.7 & $120^{\mathrm{a}}$ \\
\hline Cadmium & $7440-43-9$ & $559 \mathrm{BH} 0500.5$ & 5.25 & $450^{\mathrm{a}}$ \\
\hline Chromium & $7440-47-3$ & $559 \mathrm{BB} 0800.5$ & 20.2 & $450^{\mathrm{a}}$ \\
\hline Diesel-Range Organics & $68334-30-5$ & $559 \mathrm{BH} 0200.5$ & $\mathbf{9 2 0}$ & $\mathbf{1 0 0}^{\mathrm{c}}$ \\
\hline Dimethylphthalate & $131-11-3$ & $559 \mathrm{BB} 0800.5$ & 0.028 & $100,000^{\mathrm{a}}$ \\
\hline Lead & $7439-92-1$ & $559 \mathrm{BB} 0800.5$ & 129 & $800^{\mathrm{a}}$ \\
\hline Mercury & $7439-97-6$ & $559 \mathrm{BB} 0800.5$ & 0.0905 & $310^{\mathrm{a}}$ \\
\hline Polychlorinated Biphenyl 1260 & $11096-82-5$ & $559 \mathrm{BB} 0700.5 \mathrm{DL}$ & $\mathbf{4 . 4}$ & $\mathbf{0 . 7 4}$ \\
\hline Selenium & $7782-49-2$ & $559 \mathrm{BH} 1000.5$ & 0.579 & $5,100^{\mathrm{a}}$ \\
\hline Silver & $7440-22-4$ & $559 \mathrm{BH} 0303.5$ & 13 & $5,100^{\mathrm{a}}$ \\
\hline Trichlorofluoromethane & $75-69-4$ & $559 \mathrm{BB} 0800.5$ & 0.0024 & $2,000^{\mathrm{a}}$ \\
\hline
\end{tabular}

${ }^{\mathrm{a}} \mathrm{FAL}$ based on U.S. Environmental Protection Agency Region 9 Preliminary Remediation Goals (PRGs) (EPA, 2004).

${ }^{\mathrm{b}} \mathrm{NTS}$ background plus two standard deviations.

${ }^{\mathrm{c} N A C}$ 445A.2272 (NAC, 2003b)

CAS $=$ Chemical Abstracts Service $\mathrm{mg} / \mathrm{kg}=$ Milligrams per kilogram $\mathrm{PAL}=$ Preliminary action level 
Table D.1-2

Maximum Reported Radiological Values for Tier 1 Comparison

\begin{tabular}{|c|c|c|c|c|}
\hline Parameter & CAS Number & Sample No. & $\begin{array}{l}\text { Result } \\
\text { (pCi/g) }\end{array}$ & $\begin{array}{c}\mathrm{PAL}^{\mathrm{a}} \\
(\mathrm{pCi} / \mathrm{g})\end{array}$ \\
\hline Actinium-228 & 14331-83-0 & 559BH0105.5 & 4.33 & 15 \\
\hline Antimony-125 & $14234-35-6$ & 559BВ0800.5 & 22.6 & 18.1 \\
\hline Bismuth-212 & $14913-49-6$ & 559BH0600.5 & 2.79 & 5 \\
\hline Bismuth-214 & $14733-03-0$ & 559BH0105.5 & 2.71 & 15 \\
\hline Cobalt-60 & $10198-40-0$ & 559BВ0800.5 & 6.18 & 2.7 \\
\hline Cesium-137 & $10045-97-3$ & 559BВ0800.5 & 1,530 & 12.2 \\
\hline Lead-212 & 15092-94-1 & 559BH0105.5 & 5.39 & 15 \\
\hline Lead-214 & $15067-28-4$ & 559BH0105.5 & 3.3 & 15 \\
\hline Plutonium-238 & 13981-16-3 & 559BB0800.5 & 11.9 & 13 \\
\hline Plutonium-239 & $15117-48-3$ & 559BВ0800.5 & 37.4 & 12.7 \\
\hline Strontium-90 & 10098-97-2 & 559BВ0800.5 & 207 & 838 \\
\hline Thorium-234 & 15065-10-8 & 559BH0900.5 & 3.2 & 105 \\
\hline Thallium-208 & $14913-50-9$ & 559BH0105.5 & 1.6 & 15 \\
\hline
\end{tabular}

${ }^{a}$ PALs used as action levels. The PALs for radiological contaminants are based on background or the National Council on Radiation Protection and Measurements Report No. 129 recommended screening limits for construction, commercial, and industrial land-use scenario (NCRP, 1999) scaled from 25- to 15-millirem-per-year dose and the generic guidelines for residual concentration of radionuclides in DOE Order 5400.5 (DOE, 1993).

Bold indicates value exceeds the PAL.

CAS $=$ Chemical Abstracts Service

$\mathrm{PAL}=$ Preliminary action level

$\mathrm{pCi} / \mathrm{g}=$ Picocuries per gram

\section{D.1.3 Site Classification and Initial Response Action}

The four major site classifications listed in Table 3 of the ASTM standard are: (1) immediate threat to human health, safety, and/or the environment; (2) short-term (0 to 2 years) threat to human health, safety, and/or the environment; (3) long-term (greater than 2 years) threat to human health, safety, and/or the environment; (4) no demonstrated long-term threats.

Based on the CAI, CAU 559 does not present an immediate threat to human health, safety, and/or the environment; therefore, no interim response actions are necessary at this site. The CAI demonstrated that the TPH-DRO contamination present at CAU 559 has been transported on the surface down the access road from the point of release, the Compressor/Blower Pad. The results further showed that there has been minor migration into the subsurface. Analytical results from samples at four locations show minor concentrations of TPH-DRO in the native soil under the pad. A discussion of the nature and extent of contamination is presented in Appendix A. Based on this information, CAS 12-25-13 (Oil Stained Soil and Concrete) is determined to be Classification 4 as defined by ASTM Method E 1739-95 (ASTM, 1995). At this site, COCs 
were identified; however, they do not pose long-term threats to human health and/or the environment.

\section{D.1.4 Development of Tier 1 Look-Up Table of Risk-Based Screening Level Selection}

Tier 1 action levels have been defined as the PALs established during the DQO process. The PALs are a tabulation of chemical-specific (but not site-specific) screening levels based on the type of media (soil) and potential exposure scenarios (industrial). These are conservative estimates of risk, are preliminary in nature, and are used as action levels for site screening purposes. Although the PALs are not intended to be used as FALs, a FAL may be defined as the Tier 1 action level if individual constituent analytical results are below the corresponding Tier 1 action level. The FAL may also be established as the Tier I action level if individual constituent analytical results exceed the corresponding Tier 1 action level value and implementation of a corrective action based on the FAL is practical. The PALs are defined as:

- $\quad$ The EPA Region 9 Risk-Based PRGs for Industrial Soils (EPA, 2004).

- $\quad$ Background concentrations for RCRA metals will be evaluated when natural background exceeds the PAL, as is often the case with arsenic. Background is considered to be the mean plus two times the standard deviation of the mean based on data published in Mineral and Energy Resource Assessment of the Nellis Air Force Range (NBMG, 1998; Moore, 1999).

- $\quad$ Concentrations for TPH-DRO above 100 mg/kg per NAC 445A.2272 (NAC, 2003b).

- $\quad$ For COPCs without established PRGs, a protocol similar to EPA Region 9 will be used to establish an action level; otherwise, an established PRG from another EPA region may be chosen.

- $\quad$ The PALs for radioactive contaminants are based on the NCRP Report No. 129 recommended screening limits for construction, commercial, and industrial land-use scenarios (NCRP, 1999) scaled to 25-mrem/yr dose constraint (Appenzeller-Wing, 2004) and the generic guidelines for residual concentration of radionuclides in DOE Order 5400.5 (DOE, 1993).

The PALs were developed based on an industrial scenario. Because CAU 559 in Area 12 is not assigned any work stations and is considered to be in a remote or occasional use area, the use of industrial land use based PALs is conservative. The Tier 1 look-up table is defined as the PAL concentrations or activities defined in the CAIP. 


\section{D.1.5 Exposure Pathway Evaluation}

The DQOs stated that site workers would only be exposed to COCs through oral ingestion, inhalation, or dermal contact (absorption) due to exposure to potentially contaminated media (i.e., soil) at the CASs. The results of the CAI showed that all COCs identified in CAU 559 except TPH-DRO are localized near the release points and have not significantly migrated laterally or vertically in the subsurface. The TPH-DRO concentrations found in the native material and on the road were less than $30 \mathrm{mg} / \mathrm{kg}$, which is well below the $100 \mathrm{mg} / \mathrm{kg}$ PAL. Because the contaminants were only identified in the soil of the muckpile and on the access road from the T-Tunnel Muckpile, the only potential exposure pathway would be through worker contact with the contaminated soil. The minor amount of migration demonstrated by the analytical results, elapsed time since the suspected release, and the depth to groundwater supports the selection and evaluation of only the surface and shallow subsurface contact as the complete exposure pathway. Groundwater is not considered to be an exposure pathway.

\section{D.1.6 Comparison of Site Conditions with Tier 1 Risk-Based Screening Levels}

All analytical results for CAU 559 were less than corresponding Tier 1 action levels (i.e., PALs) except for those listed in Table D.1-3.

Table D.1-3

COPCs Detected Above Preliminary Action Levels

\begin{tabular}{|l|c|c|c|c|c|c|}
\hline & TPH-DRO & PCB 1260 & Co-60 & Cs-137 & Pu-239 & Sb-125 \\
\hline $\begin{array}{l}\text { CAS 12-25-13 Oil Stained Soil and } \\
\text { Concrete }\end{array}$ & $\mathrm{x}$ & $\mathrm{x}$ & $\mathrm{x}$ & $\mathrm{x}$ & $\mathrm{x}$ & $\mathrm{x}$ \\
\hline
\end{tabular}

\section{D.1.7 Evaluation of Tier 1 Results}

For all constituents at CAU 559 not listed in Section D.1.6, the FALs were established as the Tier 1 risk-based screening levels. It was determined that no further action is required for these constituents at CAU 559.

It was determined by DTRA that remediation of the remaining constituents listed in Table D.1-3 is not practical. Therefore, Tier 2 SSTLs were calculated for those constituents. 


\section{D.1.8 Tier 1 Remedial Action Evaluation}

\section{$\underline{\text { TPH-DRO Evaluation }}$}

Remediation to Tier 1 action levels would be difficult and expensive while potentially not providing a significant risk reduction. Therefore, it was determined to assess the risk to human health posed by the hazardous constituents of TPH-DRO at CAU 559 under a Tier 2 evaluation before establishing FALs for TPH-DRO constituents or implementing a corrective action.

\section{$\underline{\text { Chemical Evaluation }}$}

Actions to remediate PCB 1260 to Tier 1 action levels would be difficult and expensive while potentially not providing a significant risk reduction. The PCB 1260 concentration only exceeded the PAL in one sample. Therefore, this chemical was moved to a Tier 2 evaluation before establishing a FAL or implementing a corrective action.

\section{$\underline{\text { Radionuclide Evaluation }}$}

Actions to remediate Co-60, Cs-137, Pu-239, and Sb-125 to the Tier 1 action levels would be difficult and expensive while potentially not providing a significant risk reduction. Therefore, these radionuclides were moved to a Tier 2 evaluation before establishing FALs or implementing a corrective action.

\section{D.1.9 Tier 2 Evaluation}

No additional data were needed to complete a Tier 2 evaluation.

\section{D.1.10 Development of Tier 2 Table of SSTLS}

\section{Evaluation of TPH-DRO SSTLS}

The ASTM Method E 1739-95 (ASTM, 1995) stipulates that risk evaluations for TPH-DRO contamination be calculated and evaluated based on the risk posed by the potentially hazardous constituents of TPH-DRO. Section 6.4.3, "Use of Total Petroleum Hydrocarbon Measurements" of ASTM Method E 1739-95 states: "TPH-d should not be used for risk assessment because the general measure of TPH-DRO provides insufficient information about the amounts of individual chemical(s) of concern present” (see also Sections X1.5.4 and X1.42 of Method E 1739-95). Therefore, the individual potentially hazardous constituents in TPH-DRO were compared to corresponding Tier 2 SSTLs to evaluate the need for corrective action at CAU 559. Although 
Tier 2 SSTLs are generally calculated using site-specific inputs and general risk formulas, the Tier 2 SSTLs selected for the hazardous constituents of TPH-DRO are the EPA Region 9 PRGs (EPA, 2004). These SSTLs and the maximum reported level for each diesel constituent are presented in Table D.1-4.

Table D.1-4

Tier 2 SSTLs and CAU 559 Results for Hazardous Constituents of Diesel

\begin{tabular}{|c|c|c|c||}
\hline \multirow{2}{*}{ CAS No. } & Common Name & $\begin{array}{c}\text { SSTL } \\
(\mathbf{m g} / \mathbf{k g})\end{array}$ & $\begin{array}{c}\text { Maximum Reported } \\
\text { Value (mg/kg) }\end{array}$ \\
\cline { 3 - 4 } & & 70 & $\mathbf{1 2 - 2 5 - 1 3}$ \\
\hline \hline $108-67-8$ & 1,3,5-Trimethylbenzene & 175,000 & ND \\
\hline $91-57-6$ & 2-Methylnaphthalene & 1.4 & ND \\
\hline $56-55-3$ & Benzo(a)anthracene & 2.1 & ND \\
\hline $71-43-2$ & Benzene & 0.21 & ND \\
\hline $50-32-8$ & Benzo(a)pyrene & 400 & ND \\
\hline $100-41-4$ & Ethylbenzene & 190 & ND \\
\hline $91-20-3$ & Naphthalene & 520 & ND \\
\hline $108-88-3$ & Toluene & 420 & ND \\
\hline $1330-20-7$ & Total Xylene & 240 & ND \\
\hline $104-51-8$ & N-Butylbenzene & 240 & \\
\hline $103-65-1$ & N-Propylbenzene & & \\
\hline
\end{tabular}

CAS = Chemical Abstracts Service

$\mathrm{mg} / \mathrm{kg}=$ Milligrams per kilograms

$\mathrm{ND}=$ Nondetect

SSTL = Site-specific target level

\section{Evaluation of Chemical SSTLS}

The only chemical that exceeded its PAL is PCB 1260. The Tier 2 evaluation consisted of calculating Tier 2 SSTLs using site-specific inputs to standard risk equations for chemical contaminants. The SSTLS were calculated using equations which are compliant with the Risk Assessment Guidance for Superfund (RAGS) Part B procedures and were extracted from the Risk Assessment Information System (RAIS) (ORNL, 2004) located online at:

http://risk.lsd.ornl.gov/cgi-bin/prg/PRG_search. This website provides an online menu-driven environmental risk assessment system that, among other things, will calculate PRGs based on site-specific parameters. The calculated SSTL, the maximum reported level for PCB 1260, and the average concentration of all samples with positive detects of PCB 1260 are presented in Table D.1-5. The CAS-specific occasional use scenario FAL established for this chemical constituent is the SSTL listed in Table D.1-5. 
Table D.1-5

Tier 2 SSTLs and CAU 559 Results for Chemical Constituents

\begin{tabular}{||c|c||c|c|c|}
\hline \hline \multirow{2}{*}{ CAS } & \multirow{2}{*}{$\begin{array}{c}\text { Common } \\
\text { Name }\end{array}$} & \multicolumn{3}{|c|}{ 12-25-13 (mg/kg) } \\
\cline { 3 - 5 } & SSTL & Maximum Result & Average \\
\hline \hline $7439-92-1$ & PCB 1260 & 72.7 & 4.4 & 1.19 \\
\hline
\end{tabular}

CAS $=$ Chemical Abstracts Service

$\mathrm{mg} / \mathrm{kg}=$ Milligrams per kilograms

SSTL = Site-specific target level

\section{Evaluation of Radiological Constituent SSTLs}

The Tier 2 evaluation consisted of evaluating the mixture of all radionuclides detected at the CAS to develop Tier 2 action levels for the radionuclides that exceeded Tier 1 levels. The CAS specific Tier 2 action levels were calculated using the RESRAD code (version 6.22) and site-specific parameters. The RESRAD calculations were based on continued use of the site under the Occasional Use Area scenario, assuming that a site worker will be on site for 10 days per year, 8 hours a day for 5 years. A more detailed discussion of the RESRAD code, site-specific parameters used, and the printed RESRAD outputs are provided in Attachment A of this appendix. These SSTLs, the maximum reported level, and the average level for each radiological constituent are presented in Table D.1-6.

Table D.1-6

Tier 2 SSTLs and CAU 559 Results for Radiological Constituents

\begin{tabular}{||c|c||c|c|c||}
\hline \multirow{2}{*}{ CAS Number } & \multirow{2}{*}{$\begin{array}{c}\text { Common } \\
\text { Name }\end{array}$} & \multicolumn{3}{|c||}{ 12-25-13 (pCi/g) } \\
\cline { 3 - 5 } & SSTL & Maximum Result & Average \\
\hline \hline $10045-97-3$ & Cesium-137 & 9,270 & 1,530 & $119^{\mathrm{a}}$ \\
\hline $10198-40-0$ & Cobalt-60 & 37.5 & 6.18 & Only 1 detect \\
\hline $15117-48-3$ & Plutonium-239 & 227 & 37.4 & 3.06 \\
\hline $14234-35-6$ & Antimony-125 & 137 & 22.6 & Only 1 detect \\
\hline
\end{tabular}

${ }^{\mathrm{a}}$ This is an average of both random and biased samples

CAS = Chemical Abstracts Service

$\mathrm{pCi} / \mathrm{g}=$ Picocuries per gram

SSTL $=$ Site-specific target level

Although all detected radionuclides at the CAS were used in the sum-of-fractions calculation, and a unique Tier 2 action level was developed for all radionuclides, only the radionuclide that initially exceeded Tier 1 levels had a Tier 2 based FAL. The CAS specific FALs established for these radionuclides are the SSTLs listed in Table D.1-6. 


\section{D.1.11 Comparison of Site Conditions with Tier 2 FALs}

The Tier 2 action levels are typically compared to individual sample results from reasonable points of exposure (as opposed to the source areas as is done in Tier 1) on a point-by-point basis. Points of exposure are defined as those locations or areas at which an individual or population may come in contact with a COC originating from a CAS. For CAU 559, the Tier 2 action levels were compared to maximum constituent concentrations from each sample location and to the average concentration for the site.

A comparison of the maximum concentration of the hazardous constituents of TPH-DRO was conducted against the CAS-specific Tier 2 FALs as shown in Table D.1-4. All analytical results for potentially hazardous constituents in TPH-DRO were non-detect for the Oil Stained Soil and Concrete (CAS 12-25-13).

A comparison of the maximum concentration of the hazardous chemicals identified above the Tier 1 action levels was conducted against the CAS-specific Tier 2 FALs as shown in Table D.1-5. The analytical result for PCB 1260 did not exceed the Occasional Use Area FALs for the Oil Stained Soil and Concrete (CAS 12-25-13).

A comparison between the maximum concentration of the radionuclides identified above Tier 1 action levels (Co-60, Cs-137, Pu-239, and Sb-125) was conducted against the CAS-specific Tier 2-based FALs (the Mixture Radionuclide Guidelines) listed in Attachment A of this appendix. For the Oil Stained Soil and Concrete (CAS 12-25-13), the maximum concentration and average of the radionuclides is below their CAS-specific Occasional Use Area FALs.

\section{D.1.12 Tier 2 Remedial Action Evaluation}

Based on the Tier 2 evaluation of the TPH-DRO hazardous constituents, the chemical constituents, and the radiological constituents, CAU 559 is not contaminated with chemical or radiological constituents at concentrations that would pose a risk to the occasional use worker. However, because not enough samples were collected characterize the site to the 90 percent confidence level for TPH-DRO the site will be assumed to be contaminated with TPH-DRO and will be closed with a use restriction.

As all contaminant FALs were established as Tier 1 or Tier 2 action levels, a Tier 3 evaluation was considered unnecessary. 


\section{D.2.0 Regulatory Basis}

The FFACO Part III, Section III.3 (FFACO, 1996) stipulates conformance with Chapter 445 of the NAC (NAC, 2003a). Section NAC 445A.227 lists the factors to be considered in determining whether a corrective action is required.

Section NAC 445A.227 states:

1. Except as otherwise provided in NAC 445A.22715, the Director may require an owner or operator to take corrective action if the release of a hazardous substance, hazardous waste, or a regulated substance contaminates soil and the level of contamination exceeds the action level established for the soil pursuant to NAC 445A.2272.

2. In determining whether corrective action is required, the Director shall consider:

(a) The depth of any groundwater.

(b) The distance to irrigation wells or wells for drinking water.

(c) The type of soil that is contaminated.

(d) The annual precipitation.

(e) The type of waste or substance that was released.

(f) The extent of the contamination.

(g) The present and potential use for the land.

(h) The preferred routes of migration.

(i) The location of structures or impediments.

(j) The potential for a hazard related to fire, vapor, or explosion.

(k) Any other information specifically related to the site that the director determines is appropriate.

For a site where it is determined that corrective action is required (the corrective action process applies to all FFACO sites), Section NAC 445A.22705 (NAC, 2003c) stipulates a process to determine the necessary remediation standards (or FALs) based on an evaluation of the risk the site poses to public health and the environment. 
Section NAC 445A.22705 states:

1. Except as otherwise provided in NAC 445A.22715, if an owner or operator is required to take corrective action pursuant to NAC 445A.227, the owner or operator may conduct an evaluation of the site, based on the risk it poses to public health and the environment, to determine the necessary remediation standards or to establish that corrective action is not necessary. Such an evaluation must be conducted using Method E 1739-95, adopted by the ASTM, as it exists on October 3, 1996, or an equivalent method approved by the Division.

2. The Division shall determine whether an evaluation complies with the requirements of Method E 1739-95, or an equivalent method of testing approved by the Division. The Division may reject, require revisions be made to, or withdraw its concurrence with the evaluation at any time after the completion of the evaluation for the following reasons:

(a) The evaluation does not comply with the applicable requirements for conducting the evaluation.

(b) Conditions at the site have changed.

(c) New information or previously unidentified information that would alter the results of the evaluation becomes available and demonstrates that the release may have a detrimental impact on public health or the environment.

Therefore, in compliance with Section NAC 445A.22705, DTRA conducted "an evaluation of the site, based on the risk it poses to public health and the environment, to determine the necessary remediation standards or to establish that corrective action is not necessary" using ASTM Method E 1739-95. 


\section{D.3.0 Recommendations}

Organic, inorganic, and radiological constituents detected in environmental samples during the CAI were evaluated against FALs to determine the nature and extent of COCs for CAU 559. Assessment of the data generated from the investigation activities indicates that none of the FALs for chemical and radiological constituents were exceeded. However, because not enough samples were collected characterize the site to the 90 percent confidence level for TPH-DRO, the site will be assumed to be contaminated with TPH-DRO. Because of the TPH-DRO and the exceedances of PALs by PCB 1260 and various radionuclides, closure in place with use restrictions is considered the best option for CAU 559. Given that TPH-DRO is the only COC identified under the occasional use scenario, the negligible lateral and vertical migration, and the lack of potential impact to groundwater, it would create a greater hazard to worker safety, public health, and the environment to remove the contamination, transport it, and bury it at another location.

No corrective action beyond the initiation of a use restriction is necessary. 


\section{D.4.0 References}

ASTM, see American Society for Testing and Materials.

American Society for Testing and Materials. 1995. Standard Guide for Risk-Based Corrective Action Applied at Petroleum Release Sites, ASTM E 1739-95 (Reapproved 2002).

Philadelphia, PA.

Appenzeller-Wing, J., U.S. Department of Energy, National Nuclear Security Administration Nevada Site Office. 2004. Letter to Terre A. Maize entitled "Submittal of Proposed Radiological Preliminary Action Levels (PALs) for the Industrial Sites Project.” Las Vegas, NV

DOE, see U.S. Department of Energy.

DTRA, see Defense Threat Reduction Agency.

Defense Threat Reduction Agency. 2005. Corrective Action Investigation Plan for Corrective Action Unit 559: T-Tunnel Compressor/Blower Pad, Nevada Test Site, Rev. 0. Las Vegas, $\mathrm{NV}$.

EPA, see U.S. Environmental Protection Agency.

FFACO, see Federal Facility Agreement and Consent Order.

Federal Facility Agreement and Consent Order. 1996 (as amended). Agreed to by the State of Nevada, the U.S. Department of Energy, and the U.S. Department of Defense.

Las Vega, NV.

Moore, J., Science Applications International Corporation. 1999. Memorandum to M. Todd (SAIC) entitled, "Background Concentrations for NTS and TTR Soil Samples," 3 February. Las Vegas, NV.

NAC, see Nevada Administrative Code.

NBMG, see Nevada Bureau of Mines and Geology.

NCRP, see National Council on Radiation Protection and Measurements.

National Council on Radiation Protection and Measurements. 1999. Recommended Screening Limits for Contaminated Surface Soil and Review of Factors Relevant to Site-Specific Studies, Report No. 129. Bethesda, MD.

Nevada Administrative Code. 2003a. NAC 445A, “Water Controls.” Carson City, NV. 
Nevada Administrative Code. 2003b. NAC 445A.2272, “Contamination of Soil: Establishment of Action Levels.” Carson City, NV.

Nevada Administrative Code. 2003c. NAC 445A.22705, “Contamination of Soil: Evaluation of Site by Owner or Operator; Review of Evaluation by Division,” Carson City, NV.

Nevada Bureau of Mines and Geology. 1998. Mineral and Energy Resource Assessment of the Nellis Air Force Range, Clark, Lincoln, and Nye Counties, Nevada, Open File Report 98-1. Reno, NV.

ORNL, see Oak Ridge National Laboratory.

Oak Ridge National Laboratory. 2004. Risk Assessment Information System. As accessed at http://risk.lsd.ornl.gov/cgi-bin/prg/PRG_search on 18 November.

USGS/DOE, see U.S. Geological Survey and U.S. Department of Energy.

U.S. Department of Energy. 1993. DOE Order 5400.5 Change 2, "Radiation Protection of the Public and Environment.” Washington, DC.

U.S. Environmental Protection Agency. 2004. Region 9 Preliminary Remediation Goals (PRGs). San Francisco, CA.

U.S. Geological Survey and U.S. Department of Energy. 2004. "USGS/DOE Nevada Water Wells.” As accessed at http://nevada.usgs.gov/doe_nv/sitepage_temp.cfm?site_id= 371106116110401 on 8 March. 


\section{Attachment A}

Derivation of Residual Radioactive Material

Guidelines for Radionuclides in Soil at Corrective Action Unit (CAU) 559, T-Tunnel Compressor/Blower Pad, Nevada Test Site, Nevada 
Derivation of Residual Radioactive Material Guidelines for Radionuclides in Soil at Corrective Action Unit (CAU) 559, T-Tunnel Compressor/Blower Pad, Nevada Test Site, Nevada

November 2006

Prepared by:

Stoller-Navarro Joint Venture, 7710 W. Cheyenne, Las Vegas, Nevada 89193

Work sponsored by United States Department of Energy, National Nuclear Security Administration Nevada Operations Office, Environmental Restoration Division,

Las Vegas, Nevada 


\subsection{Introduction}

The NNSA/NSO Environmental Restoration Division, Industrial Sites Project, and DTRA have numerous soil sites impacted from the development, testing, and production of nuclear weapons that are scheduled to undergo characterization and remediation. These impacts can take the form of chemical and/or radiological contaminants. Similar to its approach for chemical contamination, the NNSA/NSO and DTRA are committed to properly evaluating, radiologically characterizing, and where appropriate, remediating these sites to ensure the doses to radiation workers and the public are maintained as low as reasonably achievable below the primary dose limits as stated in DOE Order 5400.5 (DOE, 1993).

To accomplish this, DOE must evaluate the potential for residual radioactive contamination in surface soils, and determine compliance with the requirements of DOE Order 5400.5 (DOE, 1993). The DOE Order 5400.5 requires that: “The Authorized Limits shall be established to (1) provide that, at a minimum, the basic dose limits ... will not be exceeded, or (2) be consistent with applicable generic guidelines.” Because generic guidelines have not been established for volumetric residual radioactivity for the radionuclides of concern at CAU 559 land areas, Authorized Limits or FALs were derived using the RESRAD (Yu et al., 2001) computer program. The goal of this effort was to produce Authorized Limits, in units of pCi/g in soil above background, for CAU 559 that would result in radiation doses less than $25 \mathrm{mrem} / \mathrm{yr}$ to an industrial worker at the site.

To develop the FALs, a "realistic" yet conservative radiation dose analysis was conducted using approved exposure scenarios and site-specific data to determine the translation between surface soil radionuclide concentrations and individual radiation doses. For this analysis, site-specific data included soil sampling results obtained during site investigation activities at CAU 559, and meteorological data obtained from the Air Resources Laboratory/Special Operations and Research Division. This report provides the radiation dose modeling analysis supporting the technical derivation of the Authorized Limits for CAU 559, T-Tunnel Compressor/Blower Pad, Nevada Test Site, Nevada. This report also defines the radionuclides considered and approved exposure scenarios for the NTS, identifies the applicable exposure pathways and key input data or assumptions, presents the radiation doses for unit concentrations of radionuclides in soil, and establishes the FALs for CAU 559. 


\subsection{Facility Description}

Corrective Action Unit 559, T-Tunnel Compressor/Blower Pad, is located approximately 42 miles north of Mercury in Area 12 of the NTS (Figure 2-1). Corrective Action Unit 559 consists of one CAS 12-25-13, Oil Stained Soil and Concrete. T-Tunnel was used for six nuclear weapons effects tests and two high explosive non-nuclear tests between 1960 and 1997. The Compressor/Blower Pad is where the main components of the ventilation system and the air compressor for T-Tunnel were located. The equipment included air filters, blowers, air compressors, and associated electrical equipment. The Compressor Pad was constructed in the hillside above the tunnel portal. The equipment was connected to the tunnel by surface laid ventilation ducts and pipe lines that entered the tunnel through a vertical raise. The surface elevation of the pad is about 5,670 ft above mean sea level. Groundwater is 800 to $900 \mathrm{ft}$ below ground surface (USGS/DOE, 2004). The pad is approximately $150 \mathrm{ft}$ across at its widest point and $375 \mathrm{ft}$ long in a southwest-northeast direction. The thickness of the pad ranges from less than 1 to approximately $10 \mathrm{ft}$. 


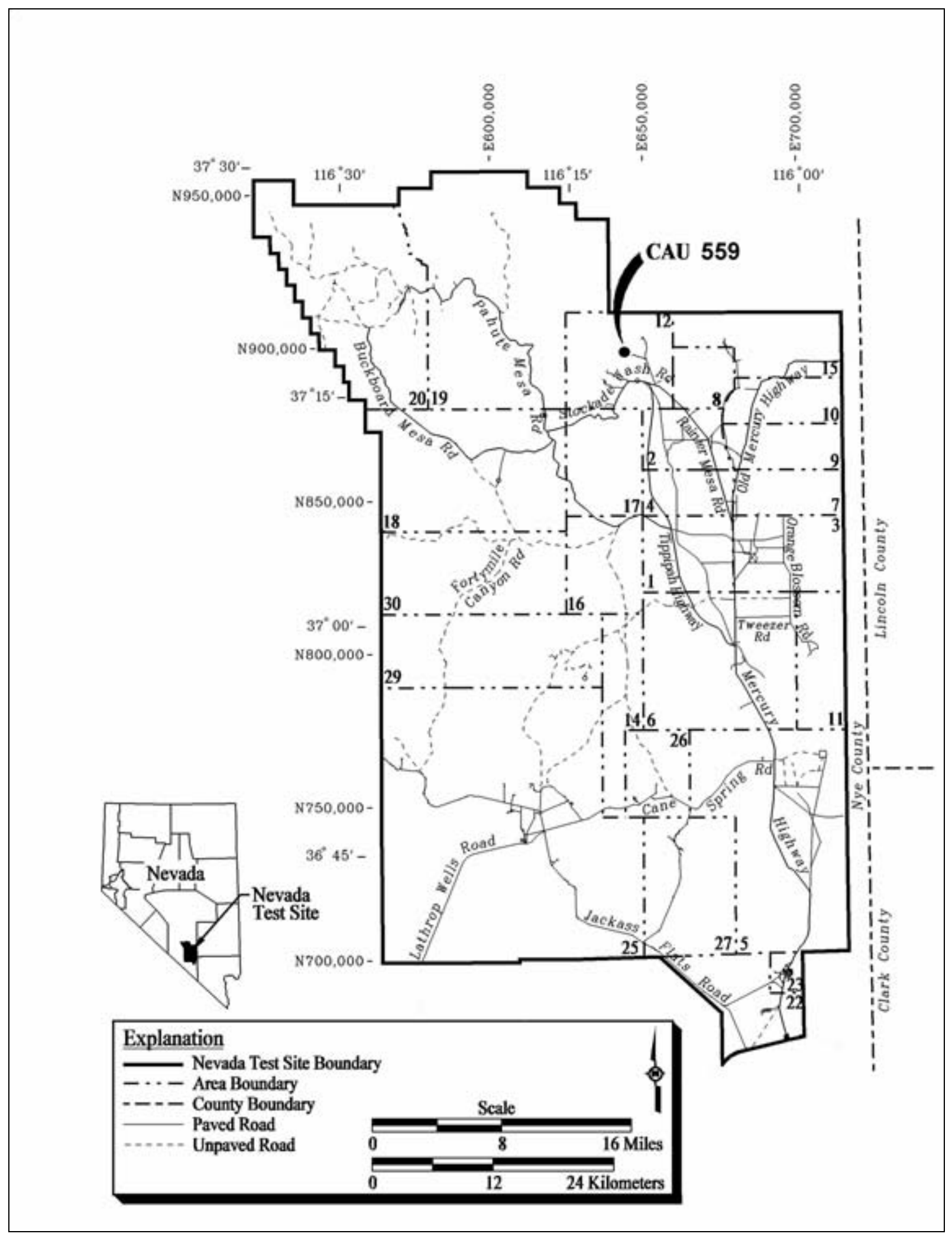

Figure 2-1

CAU 559 Location Map 


\subsection{Site Investigation Activities}

\subsection{Site Investigation Plans}

Corrective action investigation activities were performed as set forth in the CAU 559 CAIP (DTRA, 2005). The scope of the T-Tunnel Compressor/Blower Pad investigation included the following:

- Conduct walkover survey using field-screening instruments to locate areas with elevated radiological levels.

- Collect random and bias soil samples from the pad using the dry rotosonic drilling methods or hand tools.

- Collect bias soil samples from the access road leading to the pad using the dry rotosonic drilling methods or hand tools.

- Conduct VOC and radiological field screening for health and safety monitoring and as an indication of the presence or absence of COPCs.

- Log the drill cores to describe soil characteristics and document evidence of the fill/native contact.

- Conduct laboratory analysis of the environmental and QC samples to determine the presence or absence of COPCs.

The DQO process is a seven-step strategic planning approach based upon the scientific method used to plan data collection activities for CAU 559, T-Tunnel Compressor/Blower Pad. The DQOs are designed to ensure that data collected will provide sufficient and reliable information to identify, evaluate, and technically defend the recommended corrective actions (e.g., no further action, closure in place, or clean closure).

The primary objective of the investigation was to provide sufficient information and data to develop appropriate corrective action alternatives for CAU 559. This objective was achieved by identifying the nature and extent, both horizontal and vertical of COCs (i.e., COPCs at concentrations above action levels), and the vertical and lateral extent of the COCs.

The investigation strategy was developed by representatives of NDEP and NNSA/NSO, in accordance with EPA Guidance for Quality Assurance Project Plans, EPA QA/G-5 (EPA, 2002a) and Guidance for the Data Quality Objectives Process, EPA QA/G-4 (EPA, 2000b). The investigation strategy also identifies and references the associated EPA Quality System Documents entitled Data Quality Objectives for Hazardous Waste Site Investigation, EPA QA/G-4HW (EPA, 2000a), and Guidance on Choosing a Sampling Design for Environmental Data Collection, EPA QA/G-5S (EPA, 2002b), upon 
which the DQO process is based. The CAU 559 CAIP contains a detailed description of the investigation strategy and the DQO process.

\subsection{Summary of Specific Site Investigation Activities}

This section provides a brief description of work activities conducted to support the investigation of radioactive contamination at CAU 559.

\section{Surface Radiological Walkover Surveys}

The walkover radiological survey was completed in June 2005. Surface radiological land surveys were performed within safely accessible area of CAU 559, and the access road leading to the pad. The results of the surveys were used to guide the investigation and provide for site worker safety, focusing on the identification of areas with elevated radiological readings.

\section{Field Screening}

Field-screening activities for alpha and beta/gamma radiation were performed at locations, as specified in the CAU 559 CAIP (DTRA, 2005). Site-specific field screening levels (FSLs) for alpha and beta/gamma radiation were defined as the mean background activity level plus two times the standard deviation of readings from 10 background locations selected near the pad. The radiation FSLs are instrument-specific and were established for each instrument before use. The CAU 559 CADD/CR identify where field screening was conducted and how the FSLs were used to aid in the selection of sample locations.

\section{Surface and Subsurface Soil Sampling}

Intrusive investigation activities (i.e., surface and subsurface soil sampling) were conducted at the pad. Soil samples were collected using grab sampling (surface) and Rotosonic drilling or hand tools (subsurface samples). Before the start of sampling, the sampling location was screened for alpha and beta/gamma radiation. Additional screening was conducted during sample collection to both guide the investigation and to ensure that radiological controls were adequate to protect workers during sampling activities. Labeled sample containers were filled in accordance with the analytical requirements. Additional soil was transferred into an aluminum pan, homogenized, and field screened for alpha and beta/gamma radiation. All remaining sample containers were then filled. The excess soil was returned to the sampling location and no void spaces remained in the bored holes after backfilling. A detailed discussion for how the sampling met DQOs is provided in the CAU 559 CADD/CR.

\subsection{Sampling Locations}

To achieve the objective of identifying the nature and extent of both horizontal and vertical COCs, both random and bias methods were used for selecting sample locations and evaluating analytical results. The selection of soil sample locations was based on site conditions using the strategy developed during the DQO process, as outlined in the 
CAU 559 CAIP (DTRA, 2005) and subsequent Record of Technical Changes.

The sampling strategy used both biased and random sample locations for CAU 559.

Sampling points for CAU 559 were selected based on the approach provided in the CAIP, which included interpretation of existing engineering drawings, aerial and land photographs, interviews with former and current site employees, information obtained during site visits, and site-specific biasing factors. In some cases, field screening result and/or laboratory analytical results determined the need for step-out sampling locations. Sample locations were appropriately staked, labeled, and surveyed with a GPS instrument. The CAU 559 CADD/CR contains a detailed description of the actual sample locations. The actual locations have been plotted based on the coordinates collected by the GPS instrument and the result is presented in the CAU 559 CADD/CR. 


\subsection{Site Investigation Sample Results}

The RESRAD calculations are based on validated analytical soil sample results obtained during site investigation activities and other applicable information specified in the CAIP. The RESRAD calculations of the pad area were performed for the COC present at the CAU 559 using the maximum radionuclide concentrations obtained from the soil sample results. The CAU 559 CADD/CR contains a detailed description of the sample results, analytical parameters, and laboratory methods used to analyze the soil samples. The following section provides a summary of the samples taken at CAU 559.

\subsection{Soil Samples, CAS 12-25-13}

A total of 13 environmental soil samples were collected to characterize the pad, 10 environmental soil samples were collected to characterize the native material underneath the pad, and six environmental soil samples were collected to characterize the access road. The highest principal radionuclide (with a half-life longer than six months) concentrations detected at this CAS are listed in Table 4-1. These maximum radionuclide concentration values were used to perform the RESRAD calculations that involve the pad area.

Table 4-1

Radionuclide Concentrations Assigned to CAU 559

\begin{tabular}{|c|c|c||}
\hline Radionuclides & $\begin{array}{c}\text { Maximum Activity } \\
\text { Concentration } \\
(\mathbf{p C i / g )}\end{array}$ & Results Taken From \\
\hline \hline Antimony-125 & 22.6 & CAS 12-25-13 sample results \\
\hline Cesium-137 & 1530 & CAS 12-25-13 sample results \\
\hline Strontium-90 & 207 & CAS 12-25-13 sample results \\
\hline Cobalt-60 & 6.18 & CAS 12-25-13 sample results \\
\hline Plutonium-238 & 11.9 & CAS 12-25-13 sample results \\
\hline Plutonium-239 & 37.4 & CAS 12-25-13 sample results \\
\hline
\end{tabular}

$\mathrm{pCi} / \mathrm{g}=$ Picocuries per gram 


\subsection{Initial Concentrations for Principal Radionuclides}

Principal radionuclides are defined as radionuclides with a half-life greater than six months. The decay products of any principal radionuclide down to, but not including, the next principal radionuclide in its decay chain are defined as associated radionuclides. RESRAD assumes that a principal radionuclide is in secular equilibrium with its associated radionuclides at the point of exposure. Therefore, associated radionuclides and radionuclides with half-lives less than six months are not input into the RESRAD calculations.

\subsection{Authorized Values Initial Concentrations of Principal Radionuclides for Area Averaging/Anomalous Radiological Elevated Location Scenarios}

The DOE Order 5400.5 (DOE, 1993) states: "Residual concentrations of radioactive material in soil are defined as those in excess of background concentrations averaged over an area of $100 \mathrm{~m} 2$ " (5400.5, IV, 4.a.). DOE Order 5400.5 also states: "If the average concentration of any surface or below-surface area less than or equal to $25 \mathrm{~m} 2$, exceeds the limit or guideline by a factor of (100/A)0.5, [where A is the area (in square meters) of the region in which concentrations are elevated], limits for "hot-spots"[anomalous radiological elevated location] shall also be developed and applied” (5400.5, IV, 4.a.(1)). DOE G 441.1-XX (DOE, 2002) discusses the rationale for the anomalous radiological elevated location criterion.

The purpose of the anomalous radiological elevated location criterion is to ensure that applying the homogeneous criteria, in which the concentrations of residual radioactive material are averaged over a $100-\mathrm{m}^{2}$ area, does not result in the release of small areas that, because of averaging, contain unacceptably high concentrations of residual radioactive material. The anomalous radiological elevated location criterion is used to supplement Authorized Limits for larger areas and is intended to prevent excessive exposures from a small, contaminated area that is within a larger area that meets the basic Authorized Limits. Thus, it is intended for use in areas where the residual radioactive material concentrations are not uniform. Also, the above anomalous radiological elevated location criterion was derived conservatively, assuming the Authorized Limits were based on a dose constraint of $25 \mathrm{mrem} / \mathrm{yr}$ and selected to ensure unlikely exposure conditions would not cause the primary dose limit (100 mrem/yr) to be exceeded. The authorized exposure scenarios specify that the value of the maximum concentration of principal radionuclides obtained from site-specific sampling results be entered as the principal radionuclide concentrations for RESRAD anomalous radiological elevated location calculations. The authorized area parameters for RESRAD anomalous radiological elevated location calculations are $1 \mathrm{~m}^{2}, 10 \mathrm{~m}^{2}$, and $100 \mathrm{~m}^{2}$ contamination areas.

\subsection{Initial Concentrations of Principal Radionuclide for CAU 559}

As described in the CAU 559 CAIP, the pad is considered to be contaminated at the highest concentration found; therefore, the maximum radionuclide concentration values were used to perform the RESRAD calculations (DTRA, 2005). The initial radionuclide concentrations used for the three RESRAD calculations are listed in Table 4-1. 


\subsection{Inhomogeneous Contamination and Initial Radionuclide Concentrations}

A contaminated zone is inhomogeneous if it contains a contaminated region within which the concentration of a radionuclide exceeds three times the average for the contaminated zone. RESRAD uses a mathematical construct that assumes uniform distribution of radionuclides within a volume. However, RESRAD recognizes that radiological contamination is inhomogeneous in nature and provides detailed guidance for applying inhomogeneous criteria (anomalous radiological elevated location criteria, sum of fractions rule, etc.). The RESRAD User Manual states that the inhomogeneous release criteria are generally more realistic and hence less restrictive than the homogeneous release criteria. This shows that the approved initial radionuclide concentration values (i.e., arithmetic mean plus 95 percent upper confidence limit (UCL) or the maximum radionuclide concentration from the sample dataset) will result in more restrictive release criteria. The arithmetic mean plus the 95 percent UCL are used for the initial concentrations of principal radionuclides when the sample results are obtained using a random sampling method. The maximum radionuclide concentrations values are used for the initial concentrations of principal radionuclides when the sample results are obtained using a nonrandom (e.g., bias or judgmental sampling) sampling method. The latter case applies to CAU 559. 


\subsection{Authorized RESRAD Exposure Pathways and Scenarios}

This section describes the input parameters, exposures scenarios, and guidance for calculating site-specific radiological remediation levels for projects using the RESRAD computer code, as agreed to by NNSA/NSO, Stoller-Navarro Joint Venture (SNJV), Bechtel Nevada (BN), and NDEP.

\subsection{Guidance for RESRAD Calculations}

The guidance in this section was developed by NNSA/NSO, SNJV, BN, and NDEP and is only applicable to soils containing residual radioactive material. This guidance does not apply to structures, facilities, equipment, and building materials containing contaminated surfaces or volume contamination. The primary dose limit for any member of the public is 100-mrem total effective dose equivalent (TEDE) in a year. This limit applies to the sum of internal and external doses resulting from all modes of exposure to all radiation sources other than background radiation and doses received as a patient from medical sources as required by DOE 5400.5, II.1.a. (3)(a) (DOE, 1993). The dose constraint is defined as one quarter of the dose limit (i.e., 25-mrem) and will be applied to ensure that in a 1,000-year period the maximally exposed individual does not exceed the dose constraint in any single year. The requirements of Chapter IV of DOE 5400.5 Chapter IV will not specifically apply if NNSA/NSO chooses to continue to own and actively control access or use of the site. However, the radiation protection requirements in the other sections of DOE 5400.5 will apply to NNSA/NSO-owned and maintained sites.

Due to the large spatial variability in background amongst sites, the "above background criterion" will be defined as the concentration of a specific radionuclide in soil that equals or exceeds its corresponding the PAL. The source data for these radionuclide specific PALs are taken directly from NCRP Report No. 129 Table 2.1, Construction, Commercial, Industrial landuse scenario column for a 25-mrem dose constraint (NCRP, 1999). The generic guidelines for residual concentrations of Radium (Ra)-226, Ra-228, Thorium (Th)-230, and Th-232 are found in Chapter IV of DOE Order 5400.5, Change 2 "Radiation Protection of the Public and Environment."

Background radiation refers to the local area and includes:

- Concentration of naturally occurring radionuclides.

- Cosmic radiation.

- Radionuclides of anthropogenic origin that have been globally dispersed and are present at low concentrations such as fallout from nuclear weapons. (Note: This is not the case at the NTS because the historical aspects of the NTS [e.g., above- and below-ground testing] and other operations resulted in dispersion of radionuclides locally.)

Due to the impracticality of determining "true" background, a dose constraint with no background subtraction will be used (i.e., a dose constraint not in excess of background). The 
use of the dose constraint with no background subtraction is a far more conservative and sensitive approach because it does not deal with the uncertainty of natural background.

\subsection{Description of Approved Scenarios}

Based on the future land use as identified in the Nevada Test Site Resource Management Plan (DOE/NV, 1998), the following two exposure scenarios have been identified as "actual” and "likely" use scenarios. Stoller-Navarro Joint Venture has approval to use two scenarios (Scenario A and B) for use with the RESRAD code (NDEP, 2004). Both scenarios consider radiation exposures to the critical population group via the following pathways:

- Direct exposure to external radiation from the contaminated soil.

- Internal dose from inhalation of airborne radionuclides.

- Internal dose from ingestion of contaminated soil.

The two scenarios vary the parameters associated with the future land use of the site but use the same dose constraint parameter of $25 \mathrm{mrem} / \mathrm{yr}$. Scenario A is approved for sites in Mercury or within $500 \mathrm{ft}$ of an active building. Scenario B is approved for all other sites. Scenarios A and B are briefly described below.

For Scenario A, the future land use assumes continued industrial use of the site. This scenario addresses long-term exposure received by industrial workers exposed daily to residual levels of radionuclides in soil during an average workday outdoors on site (EPA, 1991). Scenario A parameters are based on the following:

- A worker will be outdoors at the site for a total of 2,000 hours per year (hrs/yr) (250 days per year, 8 hours per day) for a duration of 25 years

- Indoor fraction time is zero, which means that the worker is outside being exposed for the entire workday.

- The outdoor time fraction is 0.228 and is calculated by dividing the total work hours at the site per year (2,000 hrs/yr) by the total number of hours in a year (8,760 hrs/yr).

- Worker exposures are limited to working hours and do not include contributions from ingestion of drinking water, plant foods, meat, or fish taken from the immediate area.

For Scenario B, the future land use assumes land use restrictions with a low occupancy factor and lighter work activities at the site. The assumptions for Scenario B include the following:

- A worker will be at the site and outdoors for a total of 335 hours per year only for a duration of 25 years.

- The indoor fraction time is zero

- The outdoor time fraction is 0.038 , which is calculated by dividing the total work hours at the site per year (335 hrs/yr) by the total number of hours in a year (8,760 hrs/yr). 
- The worker exposures are limited to working hours and do not include contributions from ingestion of drinking water, plant foods, meat or fish taken from the immediate area.

When Scenario B is selected, a Use Restriction will be included at closure that will state the use scenario and the requirement for an occupant agency or entity to re-evaluate the closure if site use changes to fit the parameters of Scenario A.

Table 6-1 lists the pathways considered for Scenarios A and B.

Table 6-1

Summary of Pathways Considered for Scenarios A and B

\begin{tabular}{|c|c|c|}
\hline Pathway & Scenario A & Scenario B \\
\hline \hline External exposure & Yes & Yes \\
\hline Particulate inhalation & Yes & No \\
\hline Radon inhalation & No & No \\
\hline Ingestion of soil & Yes & No \\
\hline Ingestion of produce from on-site garden & No & No \\
\hline Ingestion of meat from on-site livestock & No & No \\
\hline Ingestion of milk from on-site livestock & No & No \\
\hline Ingestion of fish from on-site pond & No & No \\
\hline Ingestion of water from on-site well & &
\end{tabular}

\subsection{RESRAD Parameters}

The RESRAD User Manual states: “The RESRAD default parameter values were carefully selected and are realistic, although conservative, parameter values. (In most cases, use of these values will not result in underestimation of the dose or risk.) Site-specific parameters should always be used whenever possible. Therefore, use of default values that significantly overestimate the dose or risk for a particular site is discouraged.” (Yu et al., 2001)

Table 6-2 lists the RESRAD default values along with the site-specific RESRAD parameters approved for use with Scenarios A and B. A reference or reason is provided for parameters that require site-specific input. 
Table 6-2

Approved RESRAD Parameters

(Page 1 of 6)

\begin{tabular}{|c|c|c|c|c|c|}
\hline Parameter & Units & Scenario A & Scenario B & Defaults & Reference/Rationale \\
\hline Dose Conversion Factors & & & & & Use FGR 13 Morbidity \\
\hline \multicolumn{6}{|l|}{ R02 Exposure Pathways } \\
\hline Pathway 1- External Gamma & & Active & Active & & \\
\hline Pathway 2- Inhalation & & Active & Active & & \\
\hline Pathway 3- Plant Ingestion & & Suppressed & Suppressed & & \\
\hline Pathway 4- Meat Ingestion & & Suppressed & Suppressed & & \\
\hline Pathway 5- Milk Ingestion & & Suppressed & Suppressed & & \\
\hline Pathway 6- Aquatic Foods & & Suppressed & Suppressed & & \\
\hline Pathway 7- Drinking Water & & Suppressed & Suppressed & & \\
\hline Pathway 8- Soil Ingestion & & Active & Active & & \\
\hline Pathway 9- Radon & & Suppressed & Suppressed & & \\
\hline \multicolumn{6}{|l|}{ R011 Contaminated Zone } \\
\hline Area of $\mathrm{CZ}$ & $\mathrm{m}^{2}$ & Site Specific & Site Specific & $1.000 \mathrm{E}+04$ & $\begin{array}{l}\text { Maximum area of contamination out to two successive sample } \\
\text { intervals below PALs. }(\sim 15 \mathrm{ft} \text { intervals laterally) }\end{array}$ \\
\hline Thickness of CZ & $\mathrm{m}$ & Site Specific & Site Specific & $2.000 \mathrm{E}+00$ & $\begin{array}{l}\text { Maximum identified depth plus two successive intervals below } \\
\text { PALs as identified during the site characterization. ( } 5 \mathrm{ft} \text {. } \\
\text { intervals vertically) }\end{array}$ \\
\hline Length Parallel to Aquifer Flow & $\mathrm{m}$ & not used & not used & $1.000 \mathrm{E}+02$ & Not used with the above pathway selection \\
\hline Radiation Dose Limit & $\mathrm{mrem} / \mathrm{yr}$ & 25 & 25 & $2.5 \mathrm{E}+001$ & RESRAD Default (DOE, 1993) \\
\hline Elapsed Time Since Placement of Material & yr & 0.0 & 0.0 & 0.0 & RESRAD Default \\
\hline
\end{tabular}


Table 6-2

Approved RESRAD Parameters

(Page 2 of 6 )

\begin{tabular}{|c|c|c|c|c|c|}
\hline Parameter & Units & Scenario A & Scenario B & Defaults & Reference/Rationale \\
\hline \multicolumn{6}{|l|}{ R012 Initial Principal Radionuclide } \\
\hline $\begin{array}{l}\text { Site Specific Parent Radionuclide with half-life } \\
\text { greater than } 180 \text { days, does not include } \\
\text { naturally occurring and primordial } \\
\text { radionuclides }\end{array}$ & $\mathrm{pCi} / \mathrm{g}$ & Site Specific & Site Specific & 0.0 & The arithmetic mean plus the 95\% UCL for the site. \\
\hline Parameter & Units & Scenario A & Scenario B & Defaults & Reference/Rationale \\
\hline \multicolumn{6}{|c|}{ R013 Cover and Contaminated Zone Hydrological Data } \\
\hline Cover Depth & $\mathrm{m}$ & Site Specific & Site Specific & 0.0 & The minimum depth as identified during the site characterization \\
\hline Density of Cover Material & $\mathrm{g} / \mathrm{cm}^{3}$ & 1.5 & 1.5 & 1.5 & RESRAD Default unless site data significantly different \\
\hline Cover Depth Erosion Rate & $\mathrm{m} / \mathrm{yr}$ & $1.000 \mathrm{E}-03$ & $1.000 \mathrm{E}-03$ & $1.000 \mathrm{E}-03$ & RESRAD Default unless site data significantly different \\
\hline Density of Contaminated Zone & $\mathrm{g} / \mathrm{cm}^{3}$ & 1.5 & 1.5 & 1.5 & RESRAD Default unless site data significantly different \\
\hline Contamination Zone Erosion Rate & $\mathrm{m} / \mathrm{yr}$ & $1.000 \mathrm{E}-03$ & $1.000 \mathrm{E}-03$ & $1.000 \mathrm{E}-03$ & RESRAD Default unless site data significantly different \\
\hline Contaminated Zone Total Porosity & - & $4.000 \mathrm{E}-01$ & $4.000 \mathrm{E}-01$ & $4.000 \mathrm{E}-01$ & RESRAD Default unless site data significantly different \\
\hline Contaminated Zone Field Capacity & - & $2.000 \mathrm{E}-01$ & $2.000 \mathrm{E}-01$ & $2.000 \mathrm{E}-01$ & RESRAD Default unless site data significantly different \\
\hline Contaminated Zone Hydraulic Conductivity & $\mathrm{m} / \mathrm{yr}$ & $1.000 \mathrm{E}+01$ & $1.000 \mathrm{E}+01$ & $1.000 \mathrm{E}+01$ & RESRAD Default unless site data significantly different \\
\hline Contaminated Zone b Parameter & - & $5.300 \mathrm{E}+00$ & $5.300 \mathrm{E}+00$ & $5.300 \mathrm{E}+00$ & RESRAD Default unless site data significantly different \\
\hline Average Annual Wind Speed & $\mathrm{m} / \mathrm{sec}$ & Site Specific & Site Specific & $2.000 \mathrm{E}+00$ & $\begin{array}{l}\text { Data from Air Resources Laboratory } \\
\text { http://www.sord.nv.doe.gov/arlsord-1.htm }\end{array}$ \\
\hline Humidity in Air & $\mathrm{g} / \mathrm{m}^{3}$ & not used & not used & $8.000 \mathrm{E}+00$ & Not used with the above pathway selection \\
\hline Evapotranspiration Coefficient & - & $5.000 \mathrm{E}-01$ & $5.000 \mathrm{E}-01$ & 5.000E-01 & $\begin{array}{l}\text { RESRAD Default not significant due to lack of groundwater } \\
\text { pathway }\end{array}$ \\
\hline Precipitation & $\mathrm{m} / \mathrm{yr}$ & Site Specific & Site Specific & $1.000 \mathrm{E}+00$ & $\begin{array}{l}\text { Data from Air Resources Laboratory } \\
\text { http://www.sord.nv.doe.gov/arlsord-1.htm }\end{array}$ \\
\hline
\end{tabular}


Table 6-2

Approved RESRAD Parameters

(Page 3 of 6 )

\begin{tabular}{|c|c|c|c|c|c|}
\hline Parameter & Units & Scenario A & Scenario B & Defaults & Reference/Rationale \\
\hline Irrigation & $\mathrm{m} / \mathrm{yr}$ & 0 & 0 & $2.000 \mathrm{E}-01$ & Assumes no artificial supply of water to soil \\
\hline Irrigation Mode & - & overhead & overhead & overhead & RESRAD Default \\
\hline Runoff Coefficient & - & 4.000E-01 & 4.000E-01 & 2.000E-01 & $\begin{array}{l}\text { Open Sandy Loam 30\% impervious Table } 10.1 \text { (Yu, et. al., } \\
\text { 1993) }\end{array}$ \\
\hline Watershed Area for Nearby Stream or Pond & $\mathrm{m}^{2}$ & not used & not used & $1.000 \mathrm{E}+06$ & Not used with the above pathway selection \\
\hline Accuracy for Water/Soil Computations & - & not used & not used & $1.000 \mathrm{E}-03$ & Not used with the above pathway selection \\
\hline Parameter & Units & Scenario A & Scenario B & Defaults & Reference/Rationale \\
\hline \multicolumn{6}{|l|}{ R014 Saturated Zone Hydrological Data } \\
\hline Density of Saturated Zone & $\mathrm{g} / \mathrm{cm}^{3}$ & not used & not used & $1.500 \mathrm{E}+00$ & Not used with the above pathway selection \\
\hline Saturated Zone Total Porosity & - & not used & not used & 4.000E-01 & Not used with the above pathway selection \\
\hline Saturated Zone Effective Porosity & - & not used & not used & 2.000E-01 & Not used with the above pathway selection \\
\hline Saturated Zone Field Capacity & - & not used & not used & 2.000E-01 & Not used with the above pathway selection \\
\hline Saturated Zone Hydraulic Conductivity & $\mathrm{m} / \mathrm{yr}$ & not used & not used & $1.000 \mathrm{E}+02$ & Not used with the above pathway selection \\
\hline Saturated Zone Hydraulic Gradient & - & not used & not used & $2.000 \mathrm{E}-02$ & Not used with the above pathway selection \\
\hline Saturated Zone b Parameter & - & not used & not used & $5.300 \mathrm{E}+00$ & Not used with the above pathway selection \\
\hline Water Table Drop Rate & $\mathrm{m} / \mathrm{yr}$ & not used & not used & $1.000 \mathrm{E}-03$ & Not used with the above pathway selection \\
\hline Well Pump Intake Depth & $\mathrm{m}$ & not used & not used & $1.000 \mathrm{E}+01$ & Not used with the above pathway selection \\
\hline Model: Nondispersion or Mass-Balance & - & ND & ND & ND & RESRAD Default \\
\hline Well Pumping Rate & $\mathrm{m}^{3} / \mathrm{yr}$ & not used & not used & $2.500 \mathrm{E}+02$ & Not used with the above pathway selection \\
\hline \multicolumn{6}{|c|}{ R015 Uncontaminated and Unsaturated Strata Hydrological Data } \\
\hline Number of Unsaturated Zone Strata & - & not used & not used & 1 & Not used with the above pathway selection \\
\hline
\end{tabular}


Table 6-2

Approved RESRAD Parameters

(Page 4 of 6)

\begin{tabular}{|c|c|c|c|c|c|}
\hline Parameter & Units & Scenario A & Scenario B & Defaults & Reference/Rationale \\
\hline Thickness & $\mathrm{m}$ & not used & not used & $4.000 \mathrm{E}+00$ & Not used with the above pathway selection \\
\hline Soil Density & $\mathrm{g} / \mathrm{cm}^{3}$ & not used & not used & $1.500 \mathrm{E}+00$ & Not used with the above pathway selection \\
\hline Total Porosity & - & not used & not used & $4.000 \mathrm{E}-01$ & Not used with the above pathway selection \\
\hline Effective Porosity & - & not used & not used & $2.000 \mathrm{E}-01$ & Not used with the above pathway selection \\
\hline Field Capacity & - & not used & not used & $2.000 \mathrm{E}-01$ & Not used with the above pathway selection \\
\hline Soil-specific b Parameter & - & not used & not used & $5.300 \mathrm{E}+00$ & Not used with the above pathway selection \\
\hline Hydraulic Conductivity & $\mathrm{m} / \mathrm{yr}$ & not used & not used & $1.000 \mathrm{E}+01$ & Not used with the above pathway selection \\
\hline \multicolumn{6}{|c|}{ R016 Distribution Coefficients and Leach Rates } \\
\hline Contaminated Zone $\mathrm{K}_{\mathrm{d}}$ (all Zones) & $\mathrm{cm}^{3} / \mathrm{g}$ & & & & RESRAD Defaults \\
\hline Saturated Leach Rate & /yr & 0.0 & 0.0 & 0.0 & Not used \\
\hline Solubility Constant & - & 0.0 & 0.0 & 0.0 & Not used \\
\hline \multicolumn{6}{|l|}{ R017 Inhalation and External Gamma } \\
\hline Inhalation Rate & $\mathrm{m}^{3} / \mathrm{yr}$ & $8.400 \mathrm{E}+03$ & $1.230 \mathrm{E}+04$ & $8.400 \mathrm{E}+03$ & $\begin{array}{l}\text { RESRAD Default and for an individual performing outdoor } \\
\text { activities, a typical activity mix can consist of } 37 \% \text { at a moderate } \\
\text { activity level, } 28 \% \text { at both resting and light activity levels, and } \\
7 \% \text { at a heavy activity level, which results in a } 1.4 \mathrm{~m} 3 / \mathrm{h}(12,300 \\
\text { m3/yr) inhalation rate. } \\
\text { (Yu, et. al., 1993) }\end{array}$ \\
\hline Mass Loading for Inhalation & $\mathrm{g} / \mathrm{m}^{3}$ & $6.00 \mathrm{E}-04$ & $6.00 \mathrm{E}-04$ & $1 \mathrm{E}-04$ & $\begin{array}{l}\text { The estimated mass loading for construction activities. (Yu, et. } \\
\text { al., 1993) }\end{array}$ \\
\hline Exposure Duration & yr & 25 & 25 & 30 & Standard for Industrial/Commercial Scenario \\
\hline Shielding Factor Inhalation & - & 1 & 1 & 0.4 & Assumes no indoor time fraction. \\
\hline Shielding Factor External Gamma & - & 1 & 1 & 0.7 & Assumes no indoor time fraction. \\
\hline
\end{tabular}


Table 6-2

Approved RESRAD Parameters

(Page 5 of 6)

\begin{tabular}{|c|c|c|c|c|c|}
\hline Parameter & Units & Scenario A & Scenario B & Defaults & Reference/Rationale \\
\hline Fraction of Time Spent Indoors & - & 0.0 & 0.0 & 0.5 & Assumes no indoor time fraction. \\
\hline Fraction of Time Spent Outdoors & - & 0.228 & 0.038 & 0.25 & $\begin{array}{l}\text { Based on Industrial/Commercial use scenarios for standard } \\
\text { occupancy and low occupancy. }\end{array}$ \\
\hline Shape Factor & - & 1.0 & 1.0 & 1.0 & RESRAD Default \\
\hline \multicolumn{6}{|c|}{ R018 Ingestion Pathway Data, Dietary Parameters } \\
\hline Fruits, Vegetables, and Grain Consumption & $\mathrm{kg} / \mathrm{yr}$ & not used & not used & $1.600 \mathrm{E}+02$ & Not used with the above pathway selection \\
\hline Leafy Vegetable Consumption & $\mathrm{kg} / \mathrm{yr}$ & not used & not used & $1.400 \mathrm{E}+01$ & Not used with the above pathway selection \\
\hline Milk Consumption & $\mathrm{L} / \mathrm{yr}$ & not used & not used & $9.200 \mathrm{E}+01$ & Not used with the above pathway selection \\
\hline Meat and Poultry Consumption & $\mathrm{kg} / \mathrm{yr}$ & not used & not used & $6.300 \mathrm{E}+01$ & Not used with the above pathway selection \\
\hline Fish Consumption & $\mathrm{kg} / \mathrm{yr}$ & not used & not used & $5.400 \mathrm{E}+00$ & Not used with the above pathway selection \\
\hline Other Seafood Consumption & $\mathrm{kg} / \mathrm{yr}$ & not used & not used & $9.000 \mathrm{E}-01$ & Not used with the above pathway selection \\
\hline Soil Ingestion Rate & $\mathrm{g} / \mathrm{yr}$ & $1.752 \mathrm{E}+02$ & $1.752 \mathrm{E}+02$ & 36.5 & 480 mg/day (EPA, 1991) \\
\hline Drinking Water Intake & $\mathrm{L} / \mathrm{yr}$ & not used & not used & $5.100 \mathrm{E}+02$ & Not used with the above pathway selection \\
\hline Drinking Water Contaminated Fraction & - & not used & not used & $1.000 \mathrm{E}+00$ & Not used with the above pathway selection \\
\hline Household Water Contaminated Fraction & - & not used & not used & $1.000 \mathrm{E}+00$ & Not used with the above pathway selection \\
\hline Livestock Water Contaminated Fraction & - & not used & not used & $1.000 \mathrm{E}+00$ & Not used with the above pathway selection \\
\hline Irrigation Water Contaminated Fraction & - & not used & not used & $1.000 \mathrm{E}+00$ & Not used with the above pathway selection \\
\hline Aquatic Food Contamination Fraction & - & not used & not used & $5.000 \mathrm{E}-01$ & Not used with the above pathway selection \\
\hline Plant Food Contamination Fraction & - & not used & not used & -1 & Not used with the above pathway selection \\
\hline Meat Contamination Fraction & - & not used & not used & -1 & Not used with the above pathway selection \\
\hline
\end{tabular}


Table 6-2

Approved RESRAD Parameters

(Page 6 of 6)

\begin{tabular}{|c|c|c|c|c|c|}
\hline Parameter & Units & Scenario A & Scenario B & Defaults & Reference/Rationale \\
\hline Milk Contamination Fraction & - & not used & not used & -1 & Not used with the above pathway selection \\
\hline \multicolumn{6}{|l|}{ R019 Ingestion Pathway Data, Nondietary } \\
\hline Livestock Fodder Intake for Meat & kg/day & not used & not used & $6.800 \mathrm{E}+01$ & Not used with the above pathway selection \\
\hline Livestock Fodder Intake for Milk & kg/day & not used & not used & $5.500 \mathrm{E}+01$ & Not used with the above pathway selection \\
\hline Livestock Water Intake for Meat & L/day & not used & not used & $5.000 \mathrm{E}+01$ & Not used with the above pathway selection \\
\hline Livestock Water Intake for Milk & L/day & not used & not used & $1.600 \mathrm{E}+02$ & Not used with the above pathway selection \\
\hline Livestock Soil Intake & kg/day & not used & not used & $5.000 \mathrm{E}-01$ & Not used with the above pathway selection \\
\hline Mass Loading for Foliar Deposition & $\mathrm{g} / \mathrm{m}^{3}$ & not used & not used & $1.000 \mathrm{E}-04$ & Not used with the above pathway selection \\
\hline Depth of Soil Mixing layer & $\mathrm{m}$ & not used & not used & $1.500 \mathrm{E}-01$ & Not used with the above pathway selection \\
\hline Depth of Roots & $\mathrm{m}$ & not used & not used & $9.000 \mathrm{E}-01$ & Not used with the above pathway selection \\
\hline Drinking Water Fraction from Groundwater & - & not used & not used & $1.000 \mathrm{E}+00$ & Not used with the above pathway selection \\
\hline Household Water Fraction from Groundwater & - & not used & not used & $1.000 \mathrm{E}+00$ & Not used with the above pathway selection \\
\hline Livestock Water Fraction from Groundwater & - & not used & not used & $1.000 \mathrm{E}+00$ & Not used with the above pathway selection \\
\hline Irrigation Fraction from Groundwater & - & not used & not used & $1.000 \mathrm{E}+00$ & Not used with the above pathway selection \\
\hline \multicolumn{6}{|l|}{ R021 Radon } \\
\hline Radon Parameters Not Used & & & & & Not used with the above pathway selection \\
\hline
\end{tabular}




\subsection{Residual Radioactive Material Guidelines}

The residual radioactive material guideline represents the concentration of residual radioactive material that can remain in place and still allow use of that area under the designated scenario without radiological restrictions. Using site-specific parameters and sample analysis results, the radioactive material guideline, $\mathrm{G}$, can be calculated for a given dose limit of $\mathrm{H}_{\mathrm{EL}}$ for an individual as follows:

$$
\mathrm{G}=\mathrm{H}_{\mathrm{EL}} / \mathrm{DSR}
$$

where DSR is the total dose/source concentration ratio. The dose limit $\mathrm{H}_{\mathrm{EL}}$, used to derive the residual radioactive material guideline, is $25 \mathrm{mrem} / \mathrm{yr}$.

Single radionuclide guidelines are calculated for individual radionuclides such that the annual dose to industrial/construction workers at the site should not exceed an annual dose limitation of $25 \mathrm{mrem} / \mathrm{yr}$. Sites contaminated with two or more radionuclides (i.e., a mixture of radionuclides) require further evaluation to ensure that collective exposures from individual radionuclides do not exceed the $25 \mathrm{mrem} / \mathrm{yr}$ annual dose constraint. This evaluation is performed using a sum of the fractions method. The initial soil concentration of each radionuclide is divided by the single radionuclide guideline for that radionuclide to produce a ratio. These ratios are then summed. If the sum is less than or equal to unity, then the collective annual dose from all radionuclides at the site should not exceed the $25 \mathrm{mrem} / \mathrm{yr}$ annual dose constraint. If the sum does exceed unity, the annual dose to industrial/construction workers could exceed the $25 \mathrm{mrem} / \mathrm{yr}$ dose constraint, even if the concentrations of residual radionuclides at the site are below the single radionuclide guideline values. For sites where the sum of the ratios exceeds unity, residual radioactive material guidelines for mixtures of radionuclides are calculated such that the following equation is satisfied;

$$
\overline{\mathrm{M}}=\sum_{\mathrm{i}} \overline{\mathrm{S}}_{\mathrm{i}}(0) / \mathrm{G}_{\mathrm{i}}\left(\mathrm{t}_{\mathrm{m}}\right) \leq 1
$$

Where: $\quad \overline{\mathrm{M}} \quad=\quad$ average mixture sum (dimensionless)

$$
\begin{array}{ll}
\overline{\mathrm{S}}_{\mathrm{i}}(0) & =\begin{array}{l}
\text { initial concentration of the ith principal radionuclide } \\
\text { averaged over an area determined by scenario activities } \\
\text { single radionuclide soil concentration guideline for the ith } \\
\text { principal radionuclide at time t maximum. }
\end{array}
\end{array}
$$

For a site where the sum of the ratios does not exceed unity, the residual radioactive guidelines for single radionuclides are the radionuclide concentrations to be used as the FAL. For sites where the sum of the ratios exceeds unity, the residual radioactive guidelines for mixtures of radionuclides are mathematically adjusted so that the above equation is satisfied. Those adjusted values are then used as the FAL. 


\subsection{RESRAD Calculations for CAU 559}

The CAU 559, T-Tunnel Compressor/Blower Pad includes one CAS (CAS 12-25-13). This section discusses the RESRAD calculations and results for the CAU 559.

\subsection{Selection of RESRAD Exposure Scenario}

Scenario B was selected as the exposure scenario for the CAU 559 because of the remote location of the site. Because Scenario B parameters will be used for these calculations, a Use Restriction will be implemented at closure that will state the use scenario and the requirement for an occupant agency or entity to re-evaluate the closure if site use changes to fit the parameters of Scenario A.

\subsection{User Input Parameters}

The RESRAD default parameters that were modified for the calculations performed for the calculations in this report. A complete list of the RESRAD default parameters and the parameters used for CAU 559 is provided in Table A.1 in Exhibit A.

\subsection{Radionuclide Concentrations and Dose Estimates for CAU 559}

Uncertainty in the derivation of dose estimates and dose/source contribution ratios comes from the distribution of possible input parameter values, as well as uncertainty in the conceptual model used to represent the site. The pathway contributions to the total annual dose at time zero are 98 percent for external exposure, 0.49 percent for inhalation, and 1.03 percent for soil ingestion pathways. Therefore, uncertainties in the following parameters: erosion rate, thickness of contaminated zone, and occupancy factors have the greatest significance on the model predictions. The detailed results for this RESRAD exposure scenario are provided in Exhibit B.

The maximum dose contributions and total dose/source concentration ratios for the CAU 559 under Scenario B parameters have been predicted to occur at time zero. The calculated maximum dose contributions for all considered pathways are presented in Table 7-1. Figure 7-1 shows that at time zero, the TEDE to industrial/construction workers for the considered pathways is $178.1 \mathrm{mrem} / \mathrm{yr}$ and that the annual dose rate does not drop below $25 \mathrm{mrem} / \mathrm{year}$ until after the first 70 years.

Figure 7-2 shows the breakdown of the total dose into the component pathways. Together, Figures 7-1 and 7-2 show that the dose from Cs-137 at time zero is $172.4 \mathrm{mrem} /$ year and only drops to $9.56 \mathrm{mrem} / \mathrm{yr}$ after the 100-year time interval. This data also shows that the annual dose from external radiation (mostly from Cs-137) at time zero is $171.9 \mathrm{mrem} / \mathrm{year}$ and is reduced to $9.55 \mathrm{mrem} / \mathrm{yr}$ within 100 years. Within 100 years, the annual dose for Cs-137 is calculated at $9.56 \mathrm{mrem} / \mathrm{yr}$, which will account for 94.51 percent of the total annual dose.

Because Cs-137 has a half-life of 30.2 years, the concentration of Cs-137 at this site will not decay to a safe level through the radioactive decay processes within the first 70-year interval. Site remediation and/or controls that reduce workers exposures and minimize the spread of 
radioactive contamination into uncontaminated areas are recommended for this site.

\subsection{Residual Radioactive Material Guidelines for CAU 559}

The sum of the ratios for CAU 559 exceeded unity. Therefore, residual radioactive guidelines for mixtures of radionuclides were calculated for this site. Table 7-2 presents the calculations results for deriving guidelines for mixtures radionuclides for this CAU. The FALs for the CAU 559 scenario are the residual radioactive material guideline values for mixture radionuclides. 


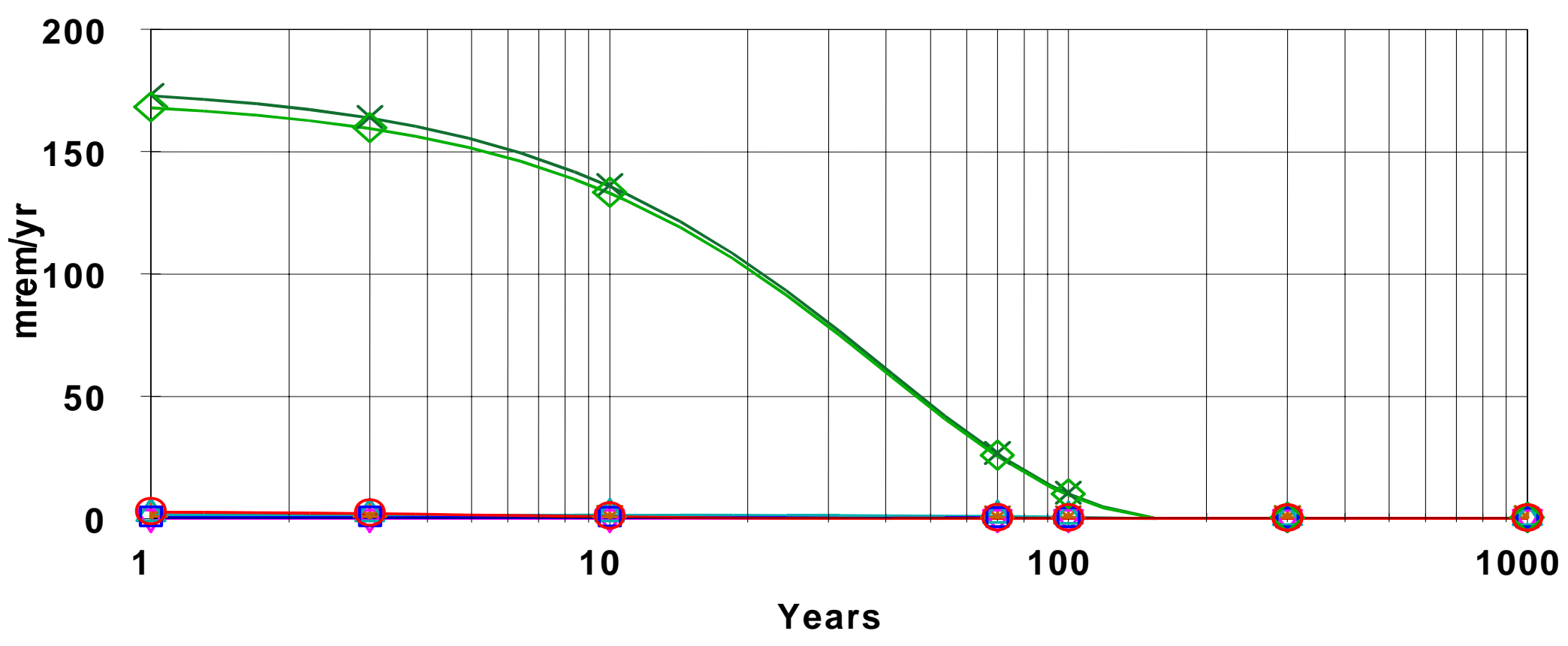

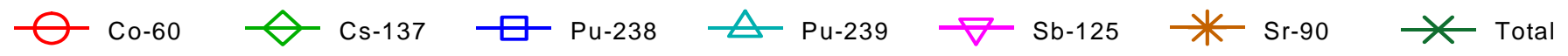

Figure 7-1. CAU 559 Scenario B: Dose Rate Per Year All Radionuclides Summed, All Pathways Summed 

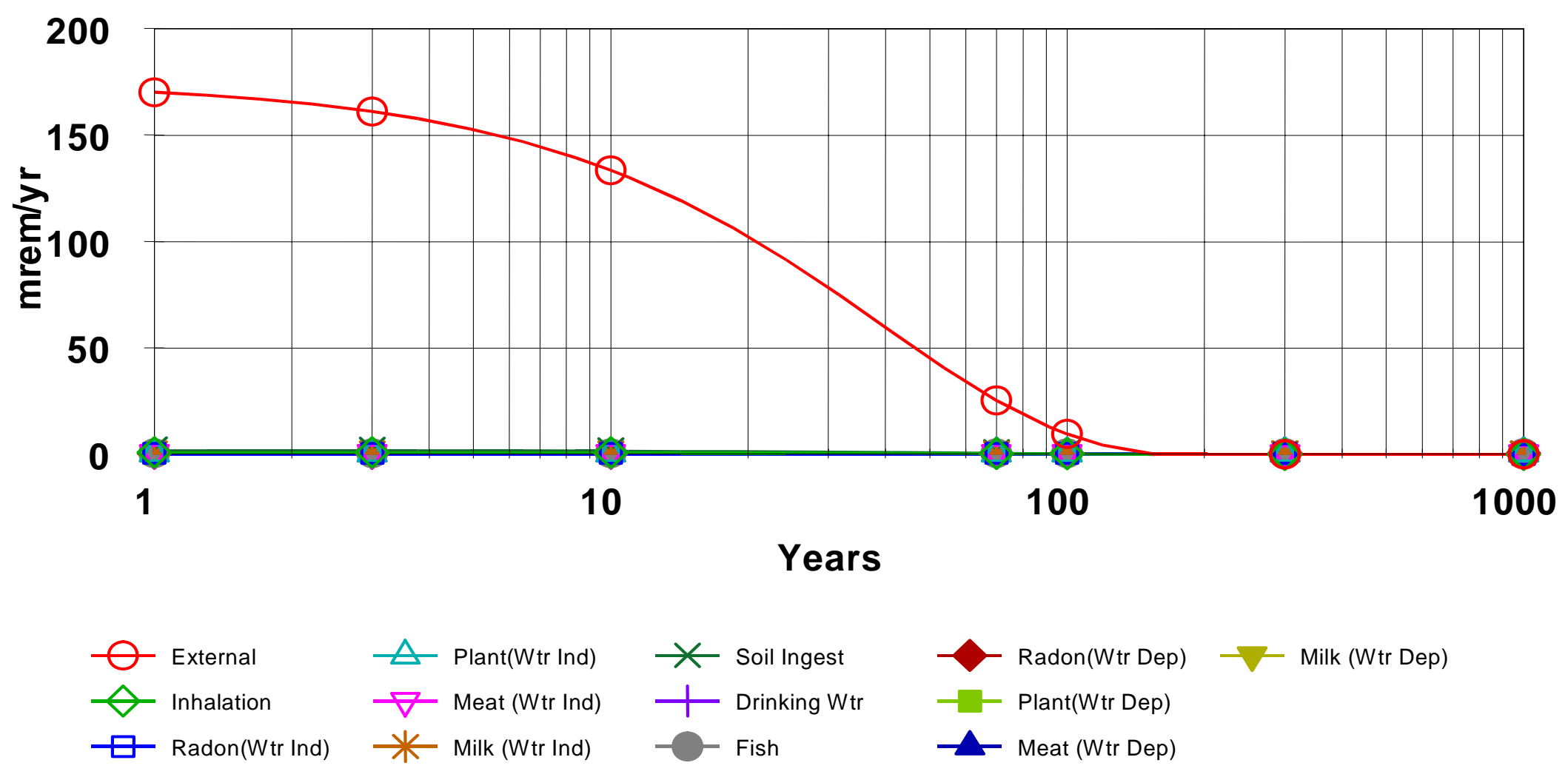

Figure 7-2. CAU 559 Scenario B: Annual Dose All Radionuclides Summed, Component Pathways 
Table 7-1

Maximum Dose* Contributions** for CAU 559 Using Scenario B

\begin{tabular}{|c|c|c|c|c|c|c|c|c|}
\hline \multirow{2}{*}{ Radionuclide } & \multicolumn{2}{|c|}{ External } & \multicolumn{2}{|c|}{ Inhalation } & \multicolumn{2}{|c|}{ Soil Ingestion } & \multicolumn{2}{|c|}{ Total } \\
\hline & Annual Dose & Fraction & Annual Dose & Fraction & Annual Dose & Fraction & Annual Dose & Fraction \\
\hline Antimony-125 & 4.004E-01 & 0.0022 & 2.806E-06 & 0.0000 & $1.168 \mathrm{E}-04$ & 0.0000 & 4.005E-01 & 0.0022 \\
\hline Cobalt-60 & $2.954 \mathrm{E}+00$ & 0.0166 & 5.316E-05 & 0.0000 & 1.033E-03 & 0.0000 & $2.955 E+00$ & 0.0166 \\
\hline Cesium-137 & 1.719E+02 & 0.9649 & 2.022E-03 & 0.0000 & 5.016E-01 & 0.0028 & $1.724 \mathrm{E}+02$ & 0.9678 \\
\hline Plutonium-238 & $6.750 \mathrm{E}-05$ & 0.0000 & 1.948E-01 & 0.0011 & $2.516 \mathrm{E}-01$ & 0.0014 & 4.465E-01 & 0.0025 \\
\hline Plutonium-239 & 3.988E-04 & 0.0000 & 6.727E-01 & 0.0038 & 8.783E-01 & 0.0049 & $1.551 \mathrm{E}+00$ & 0.0087 \\
\hline Strontium-90 & 1.746E-01 & 0.0010 & 1.108E-02 & 0.0001 & 2.047E-01 & 0.0011 & 3.904E-01 & 0.0022 \\
\hline Total & $1.754 \mathrm{E}+02$ & 0.9847 & 8.807E-01 & 0.0049 & $1.837 E+00$ & 0.0103 & 1.781E+02 & 1.0000 \\
\hline
\end{tabular}

*Dose in $\mathrm{mrem} / \mathrm{yr}$

${ }^{* *}$ Occurs at $\mathrm{t}=0$

Table 7-2

CAU 559 Sum of Fractions and Proportional Scaling

\begin{tabular}{|c|c|c|c|c|c|}
\hline Radionuclide & $\begin{array}{c}\text { Initial } \\
\text { Radionuclide } \\
\text { Concentration } \\
\text { (pCi/g) }\end{array}$ & $\begin{array}{c}\text { Single Radionuclide } \\
\text { Guidelines* (pCi/g) }\end{array}$ & $\begin{array}{l}\text { Ratio for Single } \\
\text { Radionuclide } \\
\text { Guideline (\%) }\end{array}$ & $\begin{array}{c}\text { Mixture } \\
\text { Radionuclides } \\
\text { Guidelines* } \\
\text { (pCi/g) }\end{array}$ & $\begin{array}{c}\text { Ratio for Mixture } \\
\text { Radionuclide } \\
\text { Guidelines (\%) }\end{array}$ \\
\hline Antimony-125 & $2.260 \mathrm{E}+01$ & $1.411 \mathrm{E}+03$ & 1.60 & $1.369 \mathrm{E}+02$ & 0.0117 \\
\hline Cobalt-60 & $6.180 \mathrm{E}+00$ & $5.228 \mathrm{E}+01$ & 11.82 & $3.745 \mathrm{E}+01$ & 0.3157 \\
\hline Cesiums-137 & $1.530 \mathrm{E}+03$ & $2.219 \mathrm{E}+02$ & 689.50 & $9.270 \mathrm{E}+03$ & 0.0744 \\
\hline Plutonium-238 & $1.190 \mathrm{E}+01$ & $6.663 E+02$ & 1.79 & $7.210 \mathrm{E}+01$ & 0.0248 \\
\hline Plutonium-239 & $3.740 \mathrm{E}+01$ & $6.027 \mathrm{E}+02$ & 6.21 & $2.266 \mathrm{E}+02$ & 0.0274 \\
\hline Strontium-90 & $2.070 \mathrm{E}+02$ & $1.326 \mathrm{E}+04$ & 15.61 & $1.254 \mathrm{E}+03$ & 0.0012 \\
\hline Total & $1.815 \mathrm{E}+03$ & $1.621 \mathrm{E}+04$ & 726.53 & $1.100 \mathrm{E}+04$ & 0.4552 \\
\hline
\end{tabular}

*Single radionuclide guidelines apply to areas uniformly contaminated with a single radionuclide. The mixture radionuclide guidelines apply to areas uniformly contaminated with a mixture of radionuclides. The FALs are the radionuclide guidelines for mixture radionuclides (i.e., Mixture Radionuclide column). 
Table 7-3

RESRAD Parameters Input Values for CAU 559

(Page 1 of 2)

\begin{tabular}{|c|c|c|c|c|}
\hline Parameter & Units & CAU 559 & Defaults & Reference/Rationale \\
\hline \multicolumn{5}{|c|}{ R011 Contaminated Zone } \\
\hline Area of $\mathrm{CZ}$ & $\mathrm{m}^{2}$ & $5.625 \mathrm{E}+04$ & $1.000 \mathrm{E}+04$ & Estimated using the site boundary \\
\hline Thickness of CZ & $\mathrm{m}$ & $0.150 \mathrm{E}+00$ & $2.000 \mathrm{E}+00$ & $\begin{array}{l}\text { Maximum depth from contaminated } \\
\text { samples }\end{array}$ \\
\hline \multicolumn{5}{|c|}{ R012 Initial Principal Radionuclide } \\
\hline Antimony-125 (soil) & $\mathrm{pCi} / \mathrm{g}$ & $2.260 \mathrm{E}+01$ & 0.0 & \\
\hline Cesium-137 (soil) & $\mathrm{pCi} / \mathrm{g}$ & $1.530 \mathrm{E}+03$ & 0.0 & For CAU 559: \\
\hline Cobalt-60 (soil) & $\mathrm{pCi} / \mathrm{g}$ & $6.180 \mathrm{E}+00$ & 0.0 & $\begin{array}{l}\text { The maximum concentration from sample } \\
\text { results. }\end{array}$ \\
\hline Stronium-90 (soil) & $\mathrm{pCi} / \mathrm{g}$ & $2.070 \mathrm{E}+02$ & 0.0 & \\
\hline Plutonium-238 (soil) & $\mathrm{pCi} / \mathrm{g}$ & 1.190E+01 & 0.0 & \\
\hline Plutonium-239 (soil) & $\mathrm{pCi} / \mathrm{g}$ & 3.740E+01 & 0.0 & \\
\hline \multicolumn{5}{|c|}{ R013 Cover and Contaminated Zone Hydrological Data } \\
\hline Average Annual Wind Speed & $\mathrm{m} / \mathrm{sec}$ & 3.4 & $2.000 \mathrm{E}+00$ & Data from Air Resource Laboratory (2005) \\
\hline Precipitation & $\mathrm{m} / \mathrm{yr}$ & $3.260 \mathrm{E}-01$ & $1.000 \mathrm{E}+00$ & Data from Air Resources Laboratory \\
\hline Runoff Coefficient & - & 4.000E-01 & $2.000 \mathrm{E}-01$ & $\begin{array}{l}\text { Open Sandy Loam 30\% impervious Table } \\
10.1 \text { (Yu, et al., 1993) }\end{array}$ \\
\hline
\end{tabular}


Table 7-3

RESRAD Parameters Input Values for CAU 559

(Page 2 of 2)

\begin{tabular}{|c|c|c|c|c|}
\hline Parameter & Units & CAU 559 & Defaults & Reference/Rationale \\
\hline \multicolumn{5}{|c|}{ R017 Inhalation and External Gamma } \\
\hline Inhalation Rate & $\mathrm{m}^{3} / \mathrm{yr}$ & $1.230 \mathrm{E}+04$ & $8.400 E+03$ & $\begin{array}{l}\text { RESRAD Default and for an individual } \\
\text { performing outdoor activities, a typical activity } \\
\text { mix can consist of } 37 \% \text { at a moderate activity } \\
\text { level, } 28 \% \text { at both resting and light activity } \\
\text { levels, and } 7 \% \text { at a heavy activity level, which } \\
\text { results in a } 1.4 \mathrm{~m}^{3} / \mathrm{h}\left(12,300 \mathrm{~m}^{3} / \mathrm{yr}\right) \text { inhalation } \\
\text { rate. (Yu, et al., } 1993)\end{array}$ \\
\hline Mass Loading for Inhalation & $\mathrm{g} / \mathrm{m}^{3}$ & 6.00E-04 & 1E-04 & $\begin{array}{l}\text { The estimated mass loading for construction } \\
\text { activities. (Yu, et al., 1993) }\end{array}$ \\
\hline Exposure Duration & $\mathrm{yr}$ & 25 & 30 & Standard for Industrial/Commercial Scenario \\
\hline Shielding Factor Inhalation & - & 1.0 & 0.4 & Assumes no indoor time fraction \\
\hline Shielding Factor External Gamma & - & 1.0 & 0.7 & Assumes no indoor time fraction \\
\hline Fraction of Time Spent Indoors & - & 0.0 & 0.5 & Assumes no indoor time fraction \\
\hline Fraction of Time Spent Outdoors & - & 0.038 & 0.25 & $\begin{array}{l}\text { Scenario specific based on Industrial/ } \\
\text { Commercial Use Scenarios for standard } \\
\text { occupancy and low occupancy. }\end{array}$ \\
\hline Soil Ingestion Rate & g/yr & $1.752 \mathrm{E}+02$ & 36.5 & EPA, 1991; 480 mg/day \\
\hline $\begin{array}{l}\mathrm{cm}^{3} / \mathrm{g}=\text { Cubic centimeters per gram } \\
\mathrm{g} / \mathrm{cm}^{3}=\text { Grams per cubic centimeter } \\
\mathrm{g} / \mathrm{m}^{3}=\text { Grams per cubic meter } \\
\mathrm{g} / \mathrm{yr}=\text { Grams per year } \\
\mathrm{kg} / \mathrm{day}=\text { Kilograms per day } \\
\mathrm{kg} / \mathrm{yr}=\text { Kilograms per year } \\
\mathrm{L} / \mathrm{day}=\text { Liters per day } \\
\mathrm{L} / \mathrm{yr}=\text { Liters per year } \\
\mathrm{m}=\text { Meter } \\
\mathrm{m}^{2}=\text { Square meter }\end{array}$ & \multicolumn{4}{|c|}{$\begin{array}{l}\mathrm{m} / \mathrm{sec}=\text { Meters per second } \\
\mathrm{m} / \mathrm{yr}=\text { Meters per year } \\
\mathrm{m}^{3} / \mathrm{h}=\text { Cubic meters per hour } \\
\mathrm{m}^{3} / \mathrm{yr}=\text { Cubic meters per year } \\
\mathrm{mrem} / \mathrm{yr}=\text { Millirem per year } \\
\mathrm{N} / \mathrm{A}=\text { Not applicable } \\
\mathrm{pCi} / \mathrm{g}=\text { Picocuries per gram } \\
\mathrm{yr}=\text { Year } \\
/ \mathrm{yr}=\text { Per year } \\
\mathrm{UCL}=\text { Upper confidence level }\end{array}$} \\
\hline
\end{tabular}




\subsection{References}

ARL, see Air Resources Laboratory.

Air Resources Laboratory. 2005. “Climatological Information and Data.” As accessed at http://www.sord.nv.doe.gov on 21 November 2006.

DOE, see U.S. Department of Energy.

DOE/NV, see U.S. Department of Energy, Nevada Operations Office.

DTRA, see Defense Threat Reduction Agency.

Defense Threat Reduction Agency. 2005. Corrective Action Investigation Plan for Corrective Action Unit 559: T-Tunnel Compressor/Blower Pad, Nevada Test Site, Rev 0. Prepared by SNJV. Las Vegas, NV.

EPA, see U.S. Environmental Protection Agency.

Lawrence, A., Office of Environmental Policy \& Guidance. 2002. Memorandum to Distribution entitled, "Radiation Risk Estimation from Total Effective Dose Equivalents (TEDEs)," (EH-412-2002-1), 9 August.

NCRP, see National Council on Radiation Protection and Measurements.

NDEP, see Nevada Division of Environmental Protection.

National Council on Radiation Protection and Measurements. 1999. Recommended Screening Limits for Contaminated Surface Soil and Review of Factors Relevant to Site-Specific Studies/National Council on Radiation Protection and Measurements, NCRP Report No. 129. Bethesda, MD.

Nevada Division of Environmental Protection. 2004. Review of Industrial Sites Project Document "Guidance for Calculating Industrial Sites Project Remediation Goals for Radionuclides in Soil Using the Residual Radiation (RESRAD) Computer Code."

USGS/DOE, see U.S. Geological Survey and U.S. Department of Energy.

U.S. Department of Energy. 1993. Radiation Protection of the Public and the Environment, DOE 5400.5. Washington, DC.

U.S. Department of Energy. 2002. Draft Implementation Guide, Control and Release of Property with Residual Radioactive Material, for Use with DOE 5400.5, Radiation Protection of the Public and the Environment, DOE G 441.1-XX. Washington, DC. 
U.S. Department of Energy, Nevada Operations Office. 1998. Nevada Test Site Resource Management Plan, DOE/NV-518. Las Vegas, NV.

U.S. Environmental Protection Agency. 1991. Human Health Evaluation Manual Supplemental Guidance: “Standard Default Exposure Factors.” OSWER Directive 9285.6-03.

U.S. Environmental Protection Agency. 1992. Guidance on Risk Managers and Risk Assessors. Memorandum from F.H. Habicht, Deputy Administrator. Washington, DC.

U.S. Environmental Protection Agency. 2000a. Data Quality Objectives Process for Hazardous Waste Site Investigations, EPA QA/G-4HW. Washington, DC.

U.S. Environmental Protection Agency. 2000b. Guidance for the Data Quality Objectives Process, EPA QA/G-4. Washington, DC.

U.S. Environmental Protection Agency. 2002a. Guidance for Quality Assurance Project Plans, EPA QA/G-5, EPA/240/R-02/009. Washington, DC.

U.S. Environmental Protection Agency. 2002b. Guidance on Choosing a Sampling Design for Environmental Data Collection, EPA QA/G-5S. Washington, DC.

U.S. Geological Survey and U.S. Department of Energy. 2004. "USGS/DOE Nevada Water Wells.” As accessed at http://nevada.usgs.gov/doe_nv/sitepagetemp.cfm?site_id=371106116110401 on 8 March.

Yu, C., C. Loureiro, C.C. Cheng, L.G. Jones, Y.Y. Wang, Y.P. Chia, and E. Faillace. 1993. Data Collection Handbook To Support Modeling the Impacts of Radioactive Material in Soil, ANL/EAIS-8. Chicago, IL: Environmental Assessment Division, Argonne National Laboratory.

Yu, C., A.J. Zielen, J.J Cheng, D.J. LePoire., E. Gnanapragasam, S. Kamboj, J. Arnish, A. Wallo III, W.A. Williams, and H. Peterson. 2001. User's Manual for RESRAD Version 6, ANL/EAD-4. Argonne National Laboratory, Environmental Assessment Division, Argonne, IL. 


\section{Exhibit A \\ RESRAD Parameters Used for Analysis of CAU 559 Results \\ (7 Pages)}




\section{Exhibit A}

\section{RESRAD Parameters Used for Analysis of CAU 559 Results}

The parametric values used in the RESRAD code for the analysis of the CAU 559 results are listed in Table A.1. Some parameters are site-specific, while other values are default RESRAD values. The dose conversion factors used for inhalation and ingestion were the default FGR 13 morbidity values and correspond to the guidance and recommendations per the August 9, 2002, memorandum from A. Lawrence, Office of Environmental Policy \& Guidance, to Distribution, titled "Radiation Risk Estimation from Total Effective Dose Equivalents (TEDEs)” (EH-412-2002-1) (Lawrence, 2002). 
Table A.1

\section{RESRAD Parameters}

(Page 1 of 6)

\begin{tabular}{|c|c|c|c|c|}
\hline Parameter & Units & CAU 559 & Defaults & Reference/Rationale \\
\hline \multicolumn{5}{|l|}{ R011 Contaminated Zone } \\
\hline Area of CZ & $\mathrm{m}^{2}$ & $5.625 E+04$ & $1.000 \mathrm{E}+04$ & Estimated using the site boundary \\
\hline Thickness of CZ & $\mathrm{m}$ & 1.500E-01 & $2.000 \mathrm{E}+00$ & $\begin{array}{l}\text { Maximum depth from contaminated } \\
\text { samples }\end{array}$ \\
\hline Length Parallel to Aquifer Flow & $\mathrm{m}$ & not used & $1.000 \mathrm{E}+02$ & Not Used \\
\hline Radiation Dose Limit & mrem/yr & $2.5 \mathrm{E}+001$ & $2.5 \mathrm{E}+001$ & RESRAD Default (Yu, et al., 1993) \\
\hline Elapsed Time Since Placement of Material & $\mathrm{yr}$ & 0.0 & 0.0 & RESRAD Default \\
\hline \multicolumn{5}{|l|}{ R012 Initial Principal Radionuclide } \\
\hline Antimony-125 (soil) & $\mathrm{pCi} / \mathrm{g}$ & $2.260 \mathrm{E}+01$ & 0.0 & \\
\hline Cesium-137 (soil) & $\mathrm{pCi} / \mathrm{g}$ & $1.530 \mathrm{E}+03$ & 0.0 & For CAU 559: \\
\hline Cobalt-60 (soil) & $\mathrm{pCi} / \mathrm{g}$ & $6.180 \mathrm{E}+00$ & 0.0 & $\begin{array}{l}\text { The maximum concentration from sample } \\
\text { results. }\end{array}$ \\
\hline Stronium-90 (soil) & $\mathrm{pCi} / \mathrm{g}$ & $2.070 \mathrm{E}+02$ & 0.0 & \\
\hline Plutonium-238 (soil) & $\mathrm{pCi} / \mathrm{g}$ & 1.190E+01 & 0.0 & \\
\hline Plutonium-239 (soil) & $\mathrm{pCi} / \mathrm{g}$ & $3.740 \mathrm{E}+01$ & 0.0 & \\
\hline
\end{tabular}


Table A.1

RESRAD Parameters

(Page 2 of 6)

\begin{tabular}{|c|c|c|c|c|}
\hline Parameter & Units & CAU 559 & Defaults & Reference/Rationale \\
\hline \multicolumn{5}{|c|}{ R013 Cover and Contaminated Zone Hydrological Data } \\
\hline Cover Depth & $\mathrm{m}$ & 0.0 & 0.0 & No Cover Assumed \\
\hline Density of Cover Material & $\mathrm{g} / \mathrm{cm}^{3}$ & not used & 1.5 & No Cover Assumed \\
\hline Cover Depth Erosion Rate & $\mathrm{m} / \mathrm{yr}$ & not used & 1.000E-03 & No Cover Assumed \\
\hline Density of Contaminated Zone & $\mathrm{g} / \mathrm{cm}^{3}$ & 1.5 & 1.5 & RESRAD Default \\
\hline Contamination Zone Erosion Rate & $\mathrm{m} / \mathrm{yr}$ & 1.000E-03 & 1.000E-03 & RESRAD Default \\
\hline Contaminated Zone Total Porosity & - & 4.000E-01 & 4.000E-01 & RESRAD Default \\
\hline Contaminated Zone Field Capacity & - & 2.000E-01 & 2.000E-01 & RESRAD Default \\
\hline Contaminated Zone Hydraulic Conductivity & $\mathrm{m} / \mathrm{yr}$ & $1.000 \mathrm{E}+01$ & $1.000 \mathrm{E}+01$ & RESRAD Default \\
\hline Contaminated Zone b Parameter & - & $5.300 E+00$ & $5.300 \mathrm{E}+00$ & RESRAD Default \\
\hline Average Annual Wind Speed & $\mathrm{m} / \mathrm{sec}$ & 3.4 & $2.000 \mathrm{E}+00$ & Data from Air Resource Laboratory (2005) \\
\hline Humidity in Air & $\mathrm{g} / \mathrm{m}^{3}$ & not used & $8.000 E+00$ & Not used \\
\hline Evapotranspiration Coefficient & - & 5.000E-01 & 5.000E-01 & RESRAD Default \\
\hline Precipitation & $\mathrm{m} / \mathrm{yr}$ & 3.260E-01 & $1.000 \mathrm{E}+00$ & Data from Air Resources Laboratory \\
\hline Irrigation & $\mathrm{m} / \mathrm{yr}$ & 2.000E-01 & 2.000E-01 & RESRAD Default \\
\hline Irrigation Mode & - & overhead & overhead & RESRAD Default \\
\hline Runoff Coefficient & - & 4.000E-01 & 2.000E-01 & $\begin{array}{l}\text { Open Sandy Loam 30\% impervious Table } \\
10.1 \text { (Yu, et al., 1993) }\end{array}$ \\
\hline Watershed Area for Nearby Stream or Pond & $\mathrm{m}^{2}$ & not used & $1.000 \mathrm{E}+06$ & Not used \\
\hline Accuracy for Water/Soil Computations & - & not used & 1.000E-03 & Not used \\
\hline
\end{tabular}


Table A.1

RESRAD Parameters

(Page 3 of 6)

\begin{tabular}{|c|c|c|c|c|}
\hline Parameter & Units & CAU 559 & Defaults & Reference/Rationale \\
\hline \multicolumn{5}{|l|}{ R014 Saturated Zone Hydrological Data } \\
\hline Density of Saturated Zone & $\mathrm{g} / \mathrm{cm}^{3}$ & not used & $1.500 \mathrm{E}+00$ & Not used \\
\hline Saturated Zone Total Porosity & - & not used & 4.000E-01 & Not used \\
\hline Saturated Zone Effective Porosity & - & not used & 2.000E-01 & Not used \\
\hline Saturated Zone Field Capacity & - & not used & 2.000E-01 & Not used \\
\hline Saturated Zone Hydraulic Conductivity & $\mathrm{m} / \mathrm{yr}$ & not used & $1.000 \mathrm{E}+02$ & Not used \\
\hline Saturated Zone Hydraulic Gradient & - & not used & 2.000E-02 & Not used \\
\hline Saturated Zone b Parameter & - & not used & $5.300 \mathrm{E}+00$ & Not used \\
\hline Water Table Drop Rate & $\mathrm{m} / \mathrm{yr}$ & not used & 1.000E-03 & Not used \\
\hline Well Pump Intake Depth & $\mathrm{m}$ & not used & $1.000 \mathrm{E}+01$ & Not used \\
\hline Model: Nondispersion or Mass-Balance & - & not used & ND & Not used \\
\hline Well Pumping Rate & $\mathrm{m}^{3} / \mathrm{yr}$ & not used & $2.500 E+02$ & Not used \\
\hline \multicolumn{5}{|c|}{ R015 Uncontaminated and Unsaturated Strata Hydrological Data } \\
\hline Number of Unsaturated Zone Strata & - & not used & 1 & Not used \\
\hline Thickness & $\mathrm{m}$ & not used & $4.000 \mathrm{E}+00$ & Not used \\
\hline Soil Density & $\mathrm{g} / \mathrm{cm}^{3}$ & not used & $1.500 E+00$ & Not used \\
\hline Total Porosity & - & not used & 4.000E-01 & Not used \\
\hline Effective Porosity & - & not used & 2.000E-01 & Not used \\
\hline Field Capacity & - & not used & 2.000E-01 & Not used \\
\hline Soil-specific b Parameter & - & not used & $5.300 E+00$ & Not used \\
\hline Hydraulic Conductivity & $\mathrm{m} / \mathrm{yr}$ & not used & $1.000 \mathrm{E}+01$ & Not used \\
\hline
\end{tabular}


Table A.1

RESRAD Parameters

(Page 4 of 6)

\begin{tabular}{|c|c|c|c|c|}
\hline Parameter & Units & CAU 559 & Defaults & Reference/Rationale \\
\hline \multicolumn{5}{|c|}{ R016 Distribution Coefficients and Leach Rates } \\
\hline Contaminated Zone $\mathrm{K}_{\mathrm{d}}$ (all Zones) & $\mathrm{cm}^{3} / \mathrm{g}$ & Not used & & RESRAD Default \\
\hline Saturated Leach Rate & /yr & 0.0 & 0.0 & Not used \\
\hline Solubility Constant & - & 0.0 & 0.0 & Not used \\
\hline
\end{tabular}

R017 Inhalation and External Gamma

$\begin{array}{lll}\text { Inhalation Rate } & \mathrm{m}^{3} / \mathrm{yr} & 1.230 \mathrm{E}+04\end{array}$

Mass Loading for Inhalation

Exposure Duration

Shielding Factor Inhalation

Shielding Factor External Gamma

Fraction of Time Spent Indoors

Fraction of Time Spent Outdoors

Shape Factor

R018 Ingestion Pathway Data, Dietary Parameters

Fruits, Vegetables, and Grain Consumption kg/yr

Leafy Vegetable Consumption

Milk Consumption

Meat and Poultry Consumption

$$
\mathrm{g} / \mathrm{m}^{3}
$$

$\mathrm{yr}$

$-$

$-$

$-$

$-$

$-$
6.00E-04

25

1.0

1.0

0.0

0.038

1.0

$\begin{array}{ll}\mathrm{kg} / \mathrm{yr} & \text { not used } \\ \mathrm{kg} / \mathrm{yr} & \text { not used } \\ \mathrm{L} / \mathrm{yr} & \text { not used } \\ \mathrm{kg} / \mathrm{yr} & \text { not used }\end{array}$

RESRAD Default and for an individual performing outdoor activities, a typical activity mix can consist of $37 \%$ at a moderate activity level, $28 \%$ at both resting and light activity levels, and $7 \%$ at a heavy activity level, which results in a $1.4 \mathrm{~m}^{3} / \mathrm{h}\left(12,300 \mathrm{~m}^{3} / \mathrm{yr}\right)$ inhalation rate. (Yu, et al., 1993)

E-04 The estimated mass loading for construction activities. (Yu, et al., 1993)

30 Standard for Industrial/Commercial Scenario

0.4 Assumes no indoor time fraction

0.7 Assumes no indoor time fraction

0.5 Assumes no indoor time fraction

Scenario specific based on Industrial/ Commercial Use Scenarios for standard occupancy and low occupancy.

1.0 RESRAD Default

$\begin{array}{cc}1.600 \mathrm{E}+02 & \text { Not used } \\ 1.400 \mathrm{E}+01 & \text { Not used } \\ 9.200 \mathrm{E}+01 & \text { Not used } \\ 6.300 \mathrm{E}+01 & \text { Not used }\end{array}$


Table A.1

RESRAD Parameters

(Page 5 of 6)

\begin{tabular}{|c|c|c|c|c|}
\hline Parameter & Units & CAU 559 & Defaults & Reference/Rationale \\
\hline Fish Consumption & $\mathrm{kg} / \mathrm{yr}$ & not used & $5.400 \mathrm{E}+00$ & Not used \\
\hline Other Seafood Consumption & $\mathrm{kg} / \mathrm{yr}$ & not used & $9.000 \mathrm{E}-01$ & Not used \\
\hline Soil Ingestion Rate & $g / y r$ & $1.752 E+02$ & 36.5 & EPA, 1991; 480 mg/day \\
\hline Drinking Water Intake & L/yr & not used & $5.100 \mathrm{E}+02$ & Not used \\
\hline Drinking Water Contaminated Fraction & - & not used & $1.000 \mathrm{E}+00$ & Not used \\
\hline Household Water Contaminated Fraction & - & not used & $1.000 \mathrm{E}+00$ & Not used \\
\hline Livestock Water Contaminated Fraction & - & not used & $1.000 \mathrm{E}+00$ & Not used \\
\hline Irrigation Water Contaminated Fraction & - & not used & $1.000 \mathrm{E}+00$ & Not used \\
\hline Aquatic Food Contamination Fraction & - & not used & 5.000E-01 & Not used \\
\hline Plant Food Contamination Fraction & - & not used & -1 & Not used \\
\hline Meat Contamination Fraction & - & not used & -1 & Not used \\
\hline Milk Contamination Fraction & - & not used & -1 & Not used \\
\hline \multicolumn{5}{|l|}{ R019 Ingestion Pathway Data, Nondietary } \\
\hline Livestock Fodder Intake for Meat & kg/day & not used & $6.800 \mathrm{E}+01$ & Not used \\
\hline Livestock Fodder Intake for Milk & kg/day & not used & $5.500 E+01$ & Not used \\
\hline Livestock Water Intake for Meat & L/day & not used & $5.000 E+01$ & Not used \\
\hline Livestock Water Intake for Milk & L/day & not used & $1.600 \mathrm{E}+02$ & Not used \\
\hline Livestock Soil Intake & kg/day & not used & 5.000E-01 & Not used \\
\hline Mass Loading for Foliar Deposition & $\mathrm{g} / \mathrm{m}^{3}$ & not used & 1.000E-04 & Not used \\
\hline Depth of Soil Mixing Layer & $\mathrm{m}$ & 1.500E-01 & 1.500E-01 & RESRAD Default \\
\hline Depth of Roots & $\mathrm{m}$ & not used & 9.000E-01 & Not used \\
\hline
\end{tabular}


Table A.1

RESRAD Parameters

(Page 6 of 6)

\begin{tabular}{lccc}
\hline \multicolumn{1}{c}{ Parameter } & Units & CAU 559 & Defaults \\
\hline Drinking Water Fraction from Groundwater & - & not used & $1.000 \mathrm{E}+00 \quad$ Not used \\
$\begin{array}{l}\text { Household Water Fraction from } \\
\text { Groundwater }\end{array}$ & - & not used & $1.000 \mathrm{E}+00 \quad$ Not used \\
Livestock Water Fraction from Groundwater & - & not used & $1.000 \mathrm{E}+00 \quad$ Not used \\
Irrigation Fraction from Groundwater & - & not used & $1.000 \mathrm{E}+00 \quad$ Not used \\
R021 Radon & & &
\end{tabular}

Radon Parameters Not Used

Not used

$\mathrm{cm}^{3} / \mathrm{g}=$ Cubic centimeters per gram

$\mathrm{g} / \mathrm{cm}^{3}=$ Grams per cubic centimeter

$\mathrm{g} / \mathrm{m}^{3}=$ Grams per cubic meter

$\mathrm{g} / \mathrm{yr}=$ Grams per year

$\mathrm{kg} /$ day = Kilograms per day

$\mathrm{kg} / \mathrm{yr}=$ Kilograms per year

L/day $=$ Liters per day

$\mathrm{L} / \mathrm{yr}=$ Liters per year

$\mathrm{m}=$ Meter

$\mathrm{m}^{2}=$ Square meter

$\mathrm{m} / \mathrm{sec}=$ Meters per second

$\mathrm{m} / \mathrm{yr}=$ Meters per year

$\mathrm{m}^{3} / \mathrm{h}=$ Cubic meters per hour

$\mathrm{m}^{3} / \mathrm{yr}=$ Cubic meters per year

$\mathrm{mg} /$ day = Milligrams per day

mrem/yr = Millirem per year

N/A = Not applicable

$\mathrm{pCi} / \mathrm{g}=$ Picocuries per gram

$\mathrm{yr}=$ Year

$/ \mathrm{yr}=$ Per year

$\mathrm{UCL}=$ Upper confidence level 


\section{Exhibit B RESRAD Summary Report: CAU 559 Compressor/Blower Pad}

(23 Pages) 


\section{Table of Contents}

Part I: Mixture sums and Single Radionuclide Guidelines

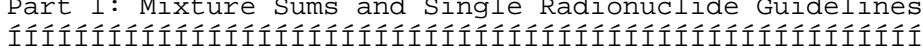

Dose Conversion Factor (and Related) Parameter Summary ... 2

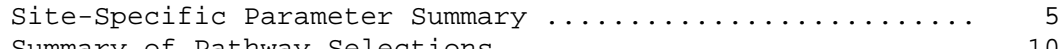

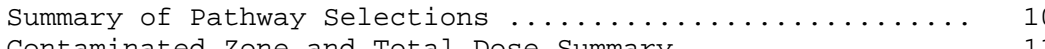

Contaminated Zone and Total Dose Summary ................ 11

Total Dose Components
Time $=0.000 \mathrm{E}+\odot \odot \ldots \ldots \ldots \ldots \ldots \ldots \ldots \ldots \ldots \ldots \ldots \ldots \ldots \ldots \ldots \ldots \ldots \ldots$

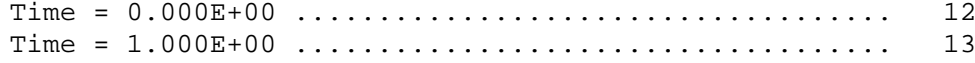

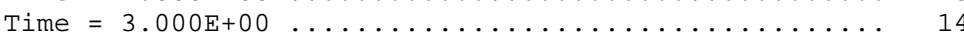

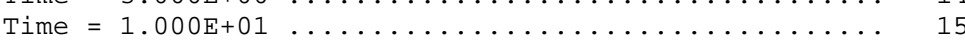

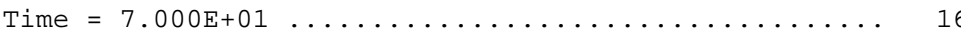

Time $=1.000 \mathrm{E}+02 \ldots \ldots \ldots \ldots \ldots \ldots \ldots \ldots \ldots \ldots \ldots \ldots, 17$

Time $=3.000 \mathrm{E}+02 \ldots \ldots \ldots \ldots \ldots \ldots \ldots \ldots \ldots \ldots \ldots \ldots, 18$

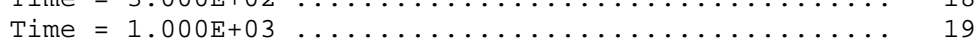

Dose/Source Ratios Summed over Ali Pathways ........... 20

Single Radionuclide Soil Guidelines ............... 20

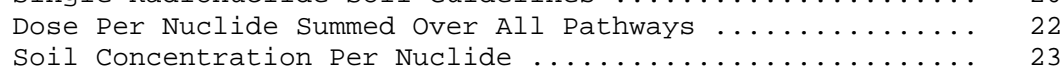


Dose Conversion Factor (and Related) Parameter Summary

File: FGR 13 Morbidity

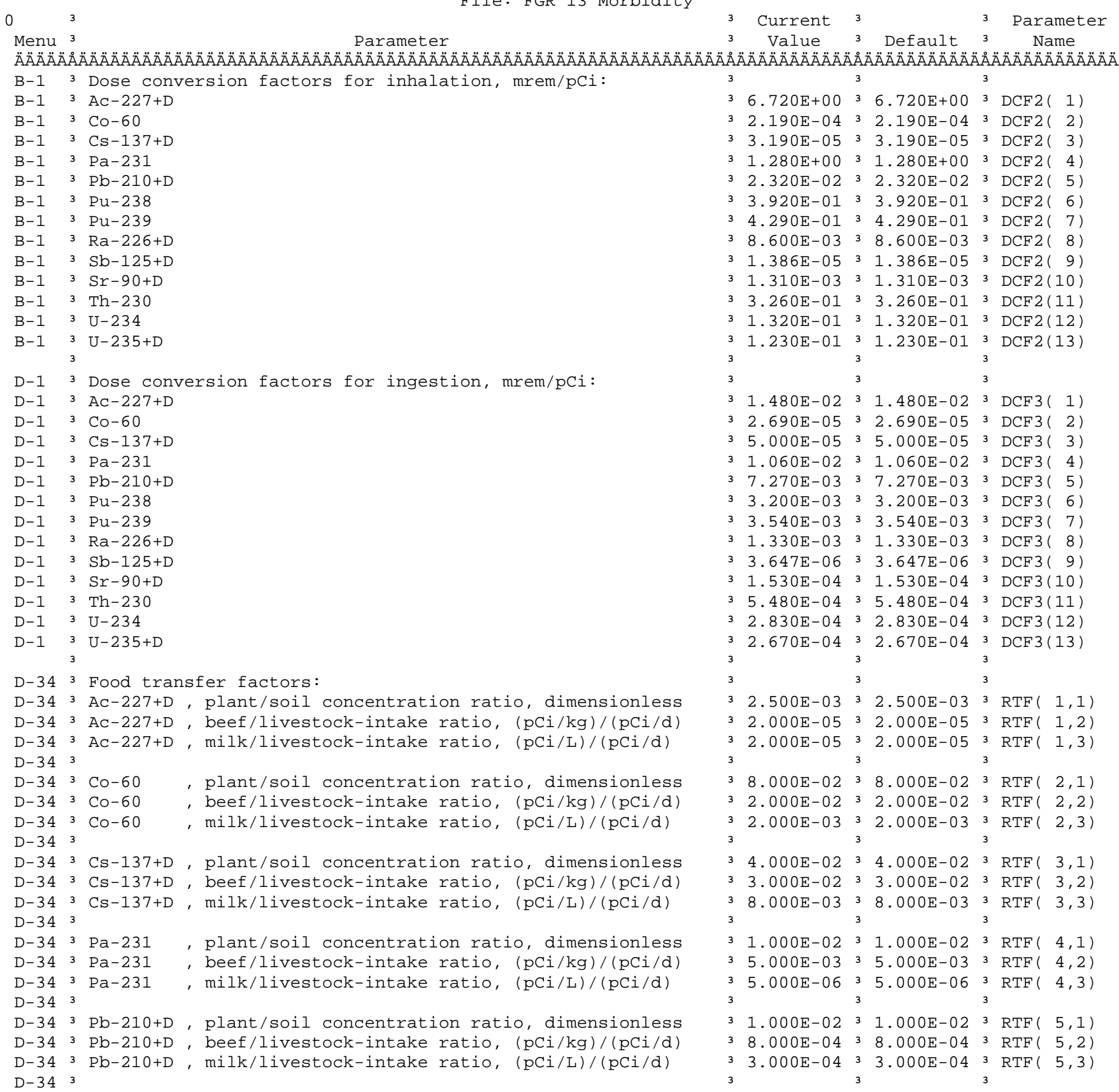


Dose Conversion Factor (and Related) Parameter Summary (continued)

Dose Conversion Factor (and Related) Parameter
File: FGR 13 Morbidity

$\bigodot_{\text {Menu }}^{3}{ }^{3}$

Parameter

3 Current 3

Value 3 Default 3 Parameter

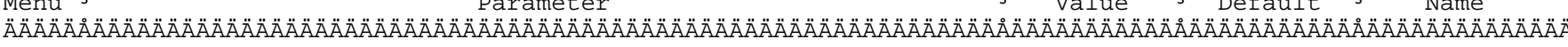

D-34 3 Pu-238, plant/soil concentration ratio, dimensionless

3 1. $000 \mathrm{E}-03 \quad 3 \quad 1.000 \mathrm{E}-033 \operatorname{RTF}(6,1)$

$\mathrm{D}-34{ }^{3} \mathrm{Pu}-238$

beef/livestock-intake ratio, $(\mathrm{pCi} / \mathrm{kg}) /(\mathrm{pCi} / \mathrm{d})$

$1.000 \mathrm{E}-04 \quad 3 \quad 1.000 \mathrm{E}-04 \quad 3 \operatorname{RTF}(6,2)$

D-34 3 Pu-238

milk/livestock intake ratio, ( $\mathrm{pCi} / \mathrm{L}) /(\mathrm{pCi} / \mathrm{d})$

$1.000 \mathrm{E}-06 \quad 3 \quad 1.000 \mathrm{E}-06 \quad 3 \operatorname{RTF}(6,3)$

D- 34

D-34 3 Pu-239, plant/soil concentration ratio, dimensionless

$\mathrm{D}-343 \mathrm{Pu}-239$, beef/livestock-intake ratio, $(\mathrm{pCi} / \mathrm{kg}) /(\mathrm{pCi} / \mathrm{d})$

$\mathrm{D}-34{ }^{3} \mathrm{Pu}-239$, milk/livestock-intake ratio, (pCi/L)/(pCi/d)

D-34 3

D-34 3 Ra-226+D, plant/soil concentration ratio, dimensionless

$\mathrm{D}-34{ }^{3} \mathrm{Ra}-226+\mathrm{D}$, beef/livestock-intake ratio, ( $\left.\mathrm{pCi} / \mathrm{kg}\right) /(\mathrm{pCi} / \mathrm{d})$

$\mathrm{D}-34{ }^{3} \mathrm{Ra}-226+\mathrm{D}$, milk/livestock-intake ratio, $(\mathrm{pCi} / \mathrm{L}) /(\mathrm{pCi} / \mathrm{d})$

D-34 3

D-34 3 Sb-125+D, plant/soil concentration ratio, dimensionless

D-34 $3 \mathrm{Sb}-125+\mathrm{D}$, beef/livestock-intake ratio, $(\mathrm{pCi} / \mathrm{kg}) /(\mathrm{pCi} / \mathrm{d})$

$\mathrm{D}-343 \mathrm{Sb}-125+\mathrm{D}$, milk/livestock-intake ratio, $(\mathrm{pCi} / \mathrm{L}) /(\mathrm{pCi} / \mathrm{d})$

$\mathrm{D}-344^{3}$

D-34 $3 \mathrm{Sr}-90+\mathrm{D}$, plant/soil concentration ratio, dimensionless

$\mathrm{D}-343 \mathrm{Sr}-90+\mathrm{D}$, beef/livestock-intake ratio, $(\mathrm{pCi} / \mathrm{kg}) /(\mathrm{pCi} / \mathrm{d})$

$\mathrm{D}-343 \mathrm{Sr}-90+\mathrm{D}, \mathrm{milk} /$ livestock-intake ratio, ( $\mathrm{pCi} / \mathrm{L}) /(\mathrm{pCi} / \mathrm{d})$

D-34 3

D-34 3 Th -230

D-34 3 Th -230

D-34 3 Th -230

$\mathrm{D}-344^{3}$

$\mathrm{D}-34{ }^{3} \mathrm{U}-234$

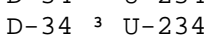

D-34 3 U -234

D-34 3

milk/livestock-intake ratio, $(\mathrm{pCi} / \mathrm{L}) /(\mathrm{pCi} / \mathrm{d})$

$\mathrm{D}-343 \mathrm{U}-235+\mathrm{D}$, plant/soil concentration ratio, dimensionless

$\mathrm{D}-343 \mathrm{U}-235+\mathrm{D}$, beef/livestock-intake ratio, $(\mathrm{pCi} / \mathrm{kg}) /(\mathrm{pCi} / \mathrm{d})$

$\mathrm{D}-34$ 3 U-235+D , milk/livestock-intake ratio, $(\mathrm{pCi} / \mathrm{L}) /(\mathrm{pCi} / \mathrm{d})$

1. $\odot \odot \odot E-\odot 3 \quad 3 \quad 1, \odot \odot \odot E-\odot 3 \quad 3 \operatorname{RTF}(7,1)$

31 1. $0 \odot \odot \mathrm{E}-\odot 4$ 3 $1.00 \odot \mathrm{1}-\odot 4$ 3 $\operatorname{RTF}(7,2)$

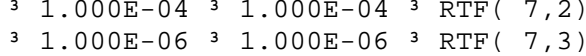

3

4. $000 \mathrm{E}-02$ 3 $4.000 \mathrm{E}-023 \operatorname{RTF}(8,1)$

3 1. $000 \mathrm{E}-03 \quad 3 \quad 1.000 \mathrm{~B}-033 \operatorname{RTF}(8,2)$

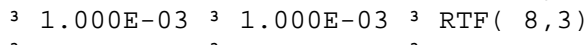

31 1. $000 \mathrm{E}-02 \quad 3 \quad 1.000 \mathrm{E}-023 \operatorname{RTF}(9,1)$

$1.000 \mathrm{-}-03 \quad 3 \quad 1.000 \mathrm{~B}-033 \operatorname{RTF}(9,2)$

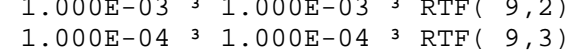

3. $000 \mathrm{E}-01 \quad 3 \quad 3.000 \mathrm{E}-013 \operatorname{RTF}(10,1)$

8.000E-03 3 8.000E-03 $3 \operatorname{RTF}(10,2)$

2. $000 \mathrm{E}-03 \quad 3 \quad 2.000 \mathrm{~B}-03 \quad 3 \operatorname{RTF}(10,3)$

$1.000 \mathrm{E}-03 \quad 3 \quad 1.000 \mathrm{E}-03 \quad 3 \operatorname{RTF}(11,1)$

1.000E-04 3 1.000E-04 $3 \operatorname{RTF}(11,2)$

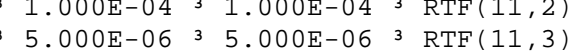

$\begin{array}{lllll}5.000 \mathrm{E}-06 & 3 & 5.000 \mathrm{E}-06 & 3 & \operatorname{RTF}(11,3) \\ & 3 & & 3 & \\ 3 & 2.500 \mathrm{E}-03 & 3 & 2.500 \mathrm{E}-03 & 3 \\ \operatorname{RTF}(12,1)\end{array}$

$\begin{array}{lllll}2.500 E-03 & 3 & 2.500 E-03 & 3 & \operatorname{RTF}(12,1) \\ 3.400 \mathrm{E}-04 & 3 & 3.400 \mathrm{E}-04 & 3 & \operatorname{RTF}(12,2)\end{array}$

6. $000 \mathrm{E}-044^{3}$ 6.000E-04 $3 \operatorname{RTF}(12,3)$

2.500E-03 $3 \quad 2.500 \mathrm{E}-03 \quad 3 \operatorname{RTF}(13,1)$

$3.400 \mathrm{E}-04 \quad 3 \quad 3.400 \mathrm{E}-04 \quad 3 \operatorname{RTF}(13,2)$

3 6. $000 \mathrm{E}-043$ 6. 6.0०E-๑4 $3 \operatorname{RTF}(13,3)$

D-5 3 Bioaccumulation factors, fresh water, L/kg:

D-5 3 AC-227+D, fish

D-5 3 AC-227+D, crustacea and mollusks

$\mathrm{D}-5 \quad 3$

D-5 3 Co-60, fish

D-5 3 Co-60, crustacea and mollusks

D-5 3

D-5 3 Cs $-137+D$, fish

D-5 3 Cs $-137+D$, crustacea and mollusks

$\mathrm{D}-5 \quad 3$

D-5 3 Pa-231, fish

D-5 3 Pa-231, crustacea and mollusks

D $-5 \quad 3$

D-5 $3 \mathrm{~Pb}-210+\mathrm{D}$, fish

D-5 3 Pb-210+D, crustacea and mollusks

$\mathrm{D}-5 \quad 3$

D-5 3 Pu-238, fish

D-5 3 Pu-238, crustacea and mollusks

$1.500 \mathrm{E}+011^{3} 1.500 \mathrm{E}+01^{3} \operatorname{BIOFAC}(1,1)$

$1.000 \mathrm{E}+03$ 3 $1.000 \mathrm{E}+033 \operatorname{BIOFAC}(1,2)$

$3.000 \mathrm{E}+02 \quad 3 \quad 3.000 \mathrm{E}+02 \quad 3 \quad \operatorname{BIOFAC}(2,1)$

$2.000 \mathrm{E}+02 \quad 3 \quad 2.000 \mathrm{E}+02 \quad 3 \quad \operatorname{BIOFAC}(2,2)$

$2.000 \mathrm{E}+033^{3} 2.000 \mathrm{E}+033^{3} \operatorname{BIOFAC}(3,1)$

1. $000 \mathrm{E}+02$ 3 $1.000 \mathrm{E}+023 \operatorname{BIOFAC}(3,2)$

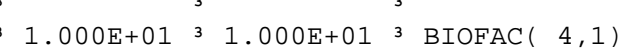

$1.100 \mathrm{E}+02 \quad 3 \quad 1 \cdot 100 \mathrm{E}+02 \quad 3 \operatorname{BIOFAC}(4,2)$

$3.000 \mathrm{E}+\odot 2 \quad 3 \quad 3.000 \mathrm{E}+\odot 2 \quad 3 \quad \mathrm{BIOFAC}(5,1)$

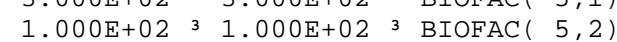

$\begin{array}{llll}3 & 1.000 \mathrm{E}+02 & 3 & 1.000 \mathrm{E}+02 \\ 3 & 3 & 3 & \operatorname{BIOFAC}(5,2)\end{array}$

$3.000 \mathrm{E}+0133.000 \mathrm{E}+013 \operatorname{BIOFAC}(6,1)$

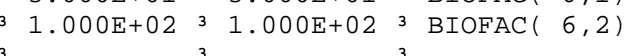


Dose Conversion Factor (and Related) Parameter Summary (continued)

File: FGR 13 Morbidity

\begin{tabular}{|c|c|c|c|c|c|c|c|c|c|}
\hline \multirow{2}{*}{ Menu } & \multicolumn{3}{|c|}{3} & \multirow{2}{*}{\multicolumn{2}{|c|}{$\begin{array}{lc}3 & \text { Current } \\
3 & \text { Value }\end{array}$}} & \multicolumn{2}{|l|}{3} & \multicolumn{2}{|c|}{3 Parameter } \\
\hline & & & Parameter & & & 3 & Default & 3 & Name \\
\hline ÄÄÄÄ & & ӒӒÄÄÄÄÄÄÄÄ & 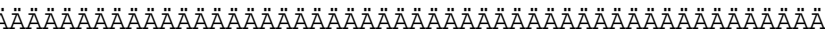 & $\ddot{A ̈ A ̊ A ́ ~}$ & 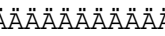 & & 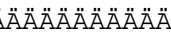 & & 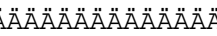 \\
\hline D-5 & 3 & $\mathrm{Pu}-239$ & fish & 3 & $3.000 \mathrm{E}+01$ & 3 & $3.000 E+01$ & 3 & $\operatorname{BIOFAC}(7,1)$ \\
\hline D-5 & 3 & Pu-239 & , crustacea and mollusks & 3 & $1.000 \mathrm{E}+02$ & 3 & $1.000 \mathrm{E}+02$ & 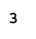 & $\operatorname{BIOFAC}(7,2)$ \\
\hline$D-5$ & 3 & & & 3 & & 3 & & 3 & \\
\hline D-5 & 3 & $\mathrm{Ra}-226+\mathrm{D}$ & fish & 3 & 5. $000 \mathrm{E}+01$ & 3 & $5.000 E+01$ & 3 & $\operatorname{BIOFAC}(8,1)$ \\
\hline D-5 & 3 & $\mathrm{Ra}-226+\mathrm{D}$ & , crustacea and mollusks & 3 & $2.500 \mathrm{E}+02$ & 3 & $2.500 E+\odot 2$ & 3 & $\operatorname{BIOFAC}(8,2)$ \\
\hline$D-5$ & 3 & & & 3 & & 3 & & 3 & \\
\hline$D-5$ & 3 & $S b-125+D$ & fish & 3 & 1. $\odot \odot \odot E+\odot 2$ & 3 & 1. $๑ \odot \odot E+\odot 2$ & 3 & $\operatorname{BIOFAC}(9,1)$ \\
\hline D-5 & & $S b-125+D$ & , crustacea and mollusks & 3 & 1. $.00 \mathrm{E}+01$ & 3 & 1. $\odot \odot \odot E+\odot 1$ & 3 & BIOFAC $(9,2)$ \\
\hline D-5 & 3 & & & 3 & & 3 & & 3 & \\
\hline$D-5$ & 3 & Sr $-90+D$ & , fish & 3 & $6.000 \mathrm{E}+01$ & 3 & $6.000 \mathrm{E}+01$ & 3 & $\operatorname{BIOFAC}(10,1)$ \\
\hline $\begin{array}{l}D-5 \\
D-5\end{array}$ & $\begin{array}{l}3 \\
3\end{array}$ & Sr $-90+D$ & , crustacea and mollusks & $\begin{array}{l}3 \\
3\end{array}$ & 1. $.000 \mathrm{E}+02$ & $\begin{array}{l}3 \\
3\end{array}$ & 1. $000 E+02$ & $\begin{array}{l}3 \\
3\end{array}$ & $\operatorname{BIOFAC}(10,2)$ \\
\hline D-5 & 3 & Th -230 & , fish & 3 & 1. $\odot 0 \odot E+\odot 2$ & 3 & 1. $\odot 00 E+\odot 2$ & 3 & $\operatorname{BIOFAC}(11,1)$ \\
\hline D-5 & 3 & Th-230 & crustacea and mollusks & 3 & $5.000 \mathrm{E}+\odot 2$ & 3 & $5.000 E+\odot 2$ & 3 & $\operatorname{BIOFAC}(11,2)$ \\
\hline$D-5$ & 3 & & & 3 & & 3 & & 3 & \\
\hline D-5 & 3 & $U-234$ & , fish & 3 & 1. $\odot \odot \odot E+\odot 1$ & 3 & $1.000 \mathrm{E}+01$ & 3 & $\operatorname{BIOFAC}(12,1)$ \\
\hline D- 5 & 3 & $U-234$ & crustacea and mollusks & 3 & $6.000 \mathrm{E}+01$ & 3 & $6.000 E+01$ & 3 & $\operatorname{BIOFAC}(12,2)$ \\
\hline$D-5$ & 3 & & & 3 & & 3 & & 3 & \\
\hline$D-5$ & 3 & $U-235+D$ & , fish & 3 & 1. $000 \mathrm{E}+01$ & 3 & $1.000 \mathrm{E}+01$ & 3 & $\operatorname{BIOFAC}(13,1)$ \\
\hline$D-5$ & 3 & $U-235+D$ & crustacea and mollusks & 3 & 6. $\odot \odot \odot E+01$ & 3 & $6.0 \odot \odot \mathrm{E}+01$ & 3 & $\operatorname{BIOFAC}(13,2)$ \\
\hline
\end{tabular}




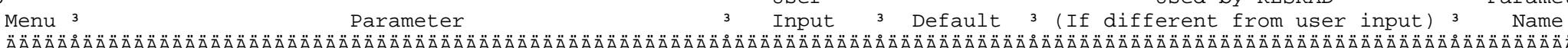

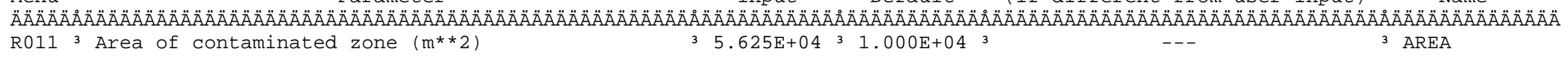

R011 3 Thickness of contaminated zone $(\mathrm{m})$

R011 3 Length parallel to aquifer flow $(\mathrm{m})$

R011 3 Time since placement of material (yr)

5.625E+04 $31.000 \mathrm{E}+043$

$\begin{array}{llll}3 & 1.500 \mathrm{E}-01 & 3 & 2.000 \mathrm{E}+00^{3} \\ 3\end{array}$

3 not used 3 1.000E $+02^{3}$

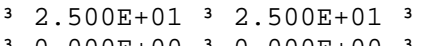

R011 3 Times for calculations $(y r)$

R011 3 Times for calculations (yr)

$\begin{array}{lll}R 011 & 3 & \text { Times for calculations }(y r) \\ \text { R011 } & 3 & \text { Times for calculations }(y r)\end{array}$

R011 3 Times for calculations (yr)

R011 3 Times for calculations (yr)

R011 3 Times for calculations ( $\mathrm{yr}$ )

R011 3 Times for calculations (yr)

R011 3 Times for calculations ( $y r$ )

R011 3 Times for calculations (yr)

$012^{3}$ Initial principal radionuclide (pci/g)

$\mathrm{R} 0123$ Initial principal radionuclide (pCi/g): $\begin{array}{lllll}\mathrm{Cs}-137 & 3 & 1.530 \mathrm{E}+\odot 3 & 3 & 0.00 \odot \mathrm{E}+\odot 0^{3}\end{array}$

$\mathrm{R} 0123$ Initial principal radionuclide (pCi/g): Pu-238 3 1.190E+01 $30.000 \mathrm{E}+0{ }^{3}$

$\mathrm{R} 0123$ Initial principal radionuclide (pCi/g): $\mathrm{Pu}-2393_{3} 3.740 \mathrm{E}+011^{3} \odot .000 \mathrm{E}+00^{3}$

$\mathrm{R} 012{ }^{3}$ Initial principal radionuclide ( $\left.\mathrm{pCi} / \mathrm{g}\right): \mathrm{Sb}_{-125} \mathbf{3}^{3} 2.260 \mathrm{E}+01^{3} \quad 0.000 \mathrm{E}+00^{3}$

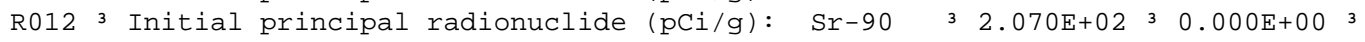

R012 3 Concentration in groundwater (pCi/L): Co-60 3 not used $30.000 \mathrm{E}+00^{3}$

R012 3 Concentration in groundwater (pCi/L): $\mathrm{Cs}-1373$ not used $30.000 \mathrm{E}+00$

$\mathrm{R} 0123$ Concentration in groundwater (pCi/L): Pu-238 3 not used $30.000 \mathrm{E}+00^{3}$

R012 3 Concentration in groundwater (pCi/L): Pu-239 3 not used $30.000 \mathrm{E}+00$

$\mathrm{R} 012{ }^{3}$ Concentration in groundwater $(\mathrm{pCi} / \mathrm{L})$ : $\mathrm{Sb}-1253$ not used $30.000 \mathrm{E}+\odot \odot$

R012 3 Concentration in groundwater $(\mathrm{pCi} / \mathrm{L}): \mathrm{Sr}-90{ }^{3}$ not used $30.000 \mathrm{E}+00^{3}$

R013 3 Cover depth $(m)$

R013 3 Density of cover material $\left(\mathrm{g} / \mathrm{cm}^{* *} 3\right)$

R013 3 Cover depth erosion rate (m/yr)

R013 3 Density of contaminated zone $\left(\mathrm{g} / \mathrm{cm}^{* *} 3\right)$

R013 3 Contaminated zone erosion rate $(\mathrm{m} / \mathrm{yr})$

R013 3 Contaminated zone total porosity

R013 3 Contaminated zone field capacity

R013 3 Contaminated zone hydraulic conductivity (m/yr)

R013 3 Contaminated zone b parameter

R013 3 Average annual wind speed (m/sec)

R013 3 Humidity in air $\left(\mathrm{g} / \mathrm{m}^{*} 3\right)$

R013 3 Evapotranspiration coefficient

R013 3 Precipitation (m/yr)

R013 3 Irrigation ( $\mathrm{m} / \mathrm{yr}$ )

R013 3 Irrigation mode

R013 3 Runoff coefficient

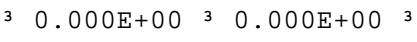

not used 3 1.500E+00 3

3 not used 3 1.000E- -33

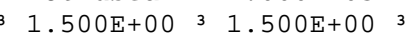

$1.000 \mathrm{E}-03$ 3 1. $1.000 \mathrm{E}-033$

4. $000 \mathrm{E}-011^{3}$ 4.000E-01 3

2. $000 \mathrm{E}-011^{3} 2.000 \mathrm{E}-013$

$\begin{array}{llll}1.000 \mathrm{E}+01 & 3 & 1.000 \mathrm{E}+01 & 3 \\ 3 & & \end{array}$

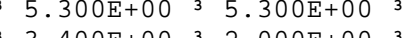

$3.400 \mathrm{E}+00$ 3 $2.000 \mathrm{E}+00^{3}$

not used $38.000 \mathrm{E}+00$

$5.000 \mathrm{E}-0131^{3} 5.000 \mathrm{E}-011^{3}$

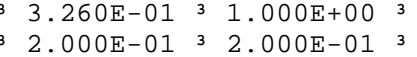

3 overhead 3 overhead 3

3 4.000E-01 3 2.000E-01

R013 3 Watershed area for nearby stream or pond $\left(m^{* *} 2\right)$

not used $31.000 \mathrm{E}+063$

R013 3 Accuracy for water/soil computations

not used $31.000 \mathrm{E}-03^{3}$

R014 3 Density of saturated zone $\left(\mathrm{g} / \mathrm{cm}^{* *} 3\right)$

R014 3 Saturated zone total porosity

R014 3 Saturated zone effective porosity

3 not used $3 \quad 1.500 \mathrm{E}+00^{3}$

not used 3 4.000E-01 3

$\begin{array}{llll}3 \text { not used } & 3 & 2.000 \mathrm{E}-01 & 3 \\ \text { not used } & 3 & 2.000 \mathrm{E}-01 & 3\end{array}$

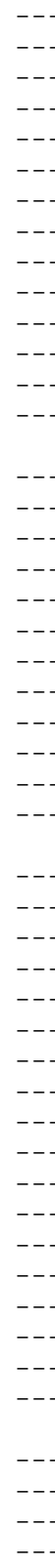

3 THICKO

3 LCZPAQ

$\begin{array}{lll}-- & 3 & \text { LCZP } \\ --- & 3 & \text { BRDL }\end{array}$

$\begin{array}{lll}-. & 3 & \text { TI } \\ -. & 3 & \text { T }(2)\end{array}$

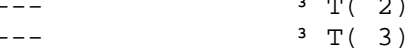

$\begin{array}{lll}3 & \mathrm{~T}(3) \\ -. & 3 & \mathrm{~T}(4)\end{array}$

- 3 T $(5)$

$\begin{array}{ll}-- & 3 \mathrm{~T}(6) \\ - & 3 \mathrm{~T}(7)\end{array}$

$\begin{array}{ll}-. & \\ - & \mathrm{T}(8)\end{array}$

.. $3 \mathrm{~T}(9)$

$3 \mathrm{~T}(10)$

3 S1 ( 2)

3 S1( 3)

$\begin{array}{ll}3 \\ \mathrm{~S} 1( & 6)\end{array}$

$3 \mathrm{~S} 1(7)$

$3 \mathrm{~S} 1(9)$

$3 \mathrm{~S} 1(10)$

3 W1 $(2)$

3 W1 2 ( 3$)$

3 W1 6 )

W1 $(7)$

3 W1 $(9)$

3 W1 $(10)$

3 COVERO

3 DENSCV

3 VCV

3 DENSCZ

$3 \mathrm{VCZ}$

3 TPCZ

3 FCCZ

$3 \mathrm{HCCZ}$

3 BCZ

3 WIND

3 HUMID

3 EVAPTR

PRECIP

3 RI

3 IDITCH

3 RUNOFF

3 WAREA

3 EPS

3 DENSAQ

$\begin{array}{lll}-- & 3 & \text { DENSAQ } \\ -- & 3 & \text { TPSZ }\end{array}$

3 EPSZ 


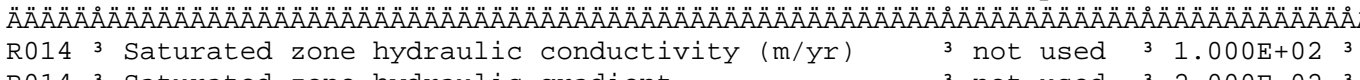

R014 Saturated zone hydraulic gradient

R014 3 Saturated zone b parameter

R014 3 Well table drop rate (m/yr)

3 not used $32.000 \mathrm{E}-022^{3}$

3 not used $35.300 \mathrm{E}+00^{3}$

R014 3 Model: Nondispersion (ND) or Mass-Balance (MB)

3 not used $31.000 \mathrm{E}-03^{3}$

not used 3 1.000E+01 3

3 not used 3 ND

R015 3 Number of unsaturated zone strata

R015 3 Unsat. zone 1, thickness $(\mathrm{m})$

R015 3 Unsat. zone 1 , soil density $\left(\mathrm{g} / \mathrm{cm}^{* *} 3\right)$

R015 3 Unsat. zone 1, total porosity

R015 3 Unsat. zone 1, effective porosity

R015 3 Unsat. zone 1, field capacity

R015 3 Unsat. zone 1, soil-specific b parameter

R015 3 Unsat. zone 1, hydraulic conductivity (m/yr)

R016 3 Distribution coefficients for Co-60

R016 3 Contaminated zone $\left(\mathrm{cm}^{* *} 3 / \mathrm{g}\right)$

R016 3 Unsaturated zone $1(\mathrm{~cm} * * 3 / \mathrm{g})$

R016 3 Saturated zone $\left(\mathrm{cm}^{* *} 3 / \mathrm{g}\right)$

R016 3 Leach rate (/yr)

RO16 3 Solubility constant

R016 3 Distribution coefficients for Cs -137

R016 3 Contaminated zone $\left(\mathrm{cm}^{* *} 3 / \mathrm{g}\right)$

R016 3 Unsaturated zone $1\left(\mathrm{~cm}^{* *} 3 / \mathrm{g}\right)$

R016 3 Saturated zone $\left(\mathrm{cm}^{* *} 3 / \mathrm{g}\right)$

$\mathrm{RO16} 3$ Leach rate (/yr)

R016 3 Solubility constant

R016 3 Distribution coefficients for $\mathrm{Pu}-238$

R016 3 Contaminated zone $\left(\mathrm{cm}^{* *} / \mathrm{g}\right)$

R016 3 Unsaturated zone $1\left(\mathrm{~cm}^{* *} 3 / \mathrm{g}\right)$

R016 3 Saturated zone $\left(\mathrm{cm}^{* *} 3 / \mathrm{g}\right)$

R016 3 Leach rate (/yr)

R016 3 Solubility constant

R016 3 Distribution coefficients for $\mathrm{Pu}-239$

R016 3 Contaminated zone $\left(\mathrm{cm}^{* *} 3 / \mathrm{g}\right)$

R016 3 Unsaturated zone $1\left(\mathrm{~cm}^{* *} 3 / \mathrm{g}\right)$

R016 3 Saturated zone $\left(\mathrm{cm}^{* *} 3 / \mathrm{g}\right)$

R016 3 Leach rate (/yr)

RO16 3 Solubility constant

R016 3 Distribution coefficients for Sb-125

R016 3 Contaminated zone $\left(\mathrm{cm}^{* *} 3 / \mathrm{g}\right)$

R016 3 Unsaturated zone $1\left(\mathrm{~cm}^{* *} 3 / \mathrm{g}\right)$

R016 3 Saturated zone $\left(\mathrm{cm}^{* *} 3 / \mathrm{g}\right)$

R016 3 Leach rate (/yr)

RO16 3 Solubility constant

not used $32.500 \mathrm{E}+02^{3}$

not used 31

not used $34.000 \mathrm{E}+00$

not used 3 1.500E+00 3

not used 3 4.000E-01 3

not used $32.000 \mathrm{E}-01^{3}$

3 not used $32.000 \mathrm{E}-013$

3 not used $35.300 \mathrm{E}+003$

not used $31.000 \mathrm{E}+01^{3}$ 3

$1.000 \mathrm{E}+03 \quad 3 \quad 1.000 \mathrm{E}+03 \quad 3$

not used 3 1.000E+03 3

not used 3 1. $000 \mathrm{E}+\mathrm{O}_{3} 3$

$0.000 \mathrm{E}+00^{3} \quad{ }^{2}, 000 \mathrm{E}+00^{3}$

$\odot .000 \mathrm{E}+0 \odot \quad 3 \quad 0.000 \mathrm{E}+\odot \odot \quad 3$

$1.000 \mathrm{E}+03$ 3 $1.000 \mathrm{E}+03 \quad 3$

3 not used $31.000 \mathrm{E}+033^{3}$

3 not used 3 1.000E+03 3

$30.000 \mathrm{E}+00$ 3 $0.000 \mathrm{E}+00^{3}$

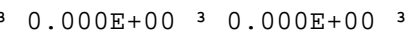
(3)

$2.000 \mathrm{E}+03 \quad 3 \quad 2.000 \mathrm{E}+03 \quad 3$

not used $32.000 \mathrm{E}+03^{3}$

3 not used 3 2.000E+03 3

$0.000 \mathrm{E}+00 \quad 3 \quad 0.000 \mathrm{E}+00^{3}$

$0.000 \mathrm{E}+0 \odot \quad 3 \quad 0.000 \mathrm{E}+0 \odot^{3}$ 3

$\begin{array}{llll}3 & 2.000 \mathrm{E}+03 \quad 3 \quad 2.000 \mathrm{E}+03 \quad 3\end{array}$

not used $32.000 \mathrm{E}+03$

not used $32.000 \mathrm{E}+03$

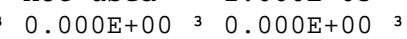

$\odot . \odot \odot \odot E+\odot \odot \quad 3 \quad \odot .0 \odot \odot E+\odot \odot \quad 3$

$\odot .000 \mathrm{E}+0 \odot \quad 3 \quad \odot .000 \mathrm{E}+0 \odot$

3 not used 3 ๑. $000 \mathrm{E}+0 \odot$

not used 3 ๑. $000 \mathrm{E}+\odot \odot$

$0.000 \mathrm{E}+00 \quad 3 \quad 0.000 \mathrm{E}+00$

$\odot .000 \mathrm{E}+0 \odot$ з $\odot .00 \Theta \mathrm{E}+\Theta \Theta^{3}$
3 HCSZ

3 HGWT

3 BSZ

3 VWT

3 DWIBWT

3 MODEL

$\begin{array}{ll}-.- & 3 \\ -- & 3 \text { UW }\end{array}$

- - $13 \mathrm{NS}$

- - $3 \mathrm{H}(1)$

- - $3 \operatorname{DENSUZ(1)}$

- - 3 TPUZ(1)

3 EPUZ(1)

3 FCUZ(1)

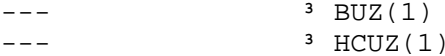

$3 \operatorname{DCNUCC}(2)$

$-\cdot-$

$8.789 \mathrm{E}-04$

not used

DCNUCU ( 2,1)

ALEACH ( 2)

SOLUBK( 2)

3 DCNUCC ( 3)

3 DCNUCU $(3,1)$

$--$

$8.789 \mathrm{E}-04$

not used

DCNUCS( 3 )

SOLUBK( 3 )

$3 \operatorname{DCNUCC}(6)$

3 DCNUCU $(6,1)$

3 DCNUCS ( 6)

3 ALEACH ( 6)

3 SOLUBK( 6$)$

$4.395 \mathrm{E}-04$

3 DCNUCC ( 7)

DCNUCU $(7,1)$

3 DCNUCS ( 7)

3 ALEACH ( 7)

3 SOLUBK( 7 )

4. 395E- 04

not used

3 DCNUCC ( 9)

$-$

- -

4. 399E+००

DCNUCU $(9,1)$

DCNUCS( 9)

$\begin{array}{ll}3 & \operatorname{ALEACH}(9) \\ 3 & \operatorname{SOLUBK}(9)\end{array}$ 


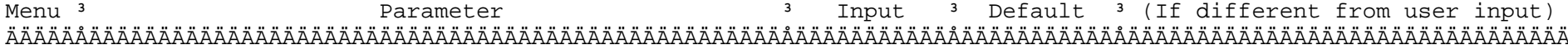

R016 3 Distribution coefficients for $\mathrm{Sr}-90$

R016 3 Contaminated zone $\left(\mathrm{cm}^{* * 3 / \mathrm{g})}\right.$

R016 3 Unsaturated zone $1\left(\mathrm{~cm}^{* *} 3 / \mathrm{g}\right)$

R016 3 Saturated zone $\left(\mathrm{cm}^{* *} 3 / \mathrm{g}\right)$

$\mathrm{R} 016$ Leach rate (/yr)

RO16 3 Solubility constant

R016 3 Distribution coefficients for daughter AC-227

R016 3 Contaminated zone $\left(\mathrm{cm}^{* *} 3 / \mathrm{g}\right)$

R016 3 Unsaturated zone $1\left(\mathrm{~cm}^{* *} 3 / \mathrm{g}\right)$

R016 3 Saturated zone $\left(\mathrm{cm}^{* *} 3 / \mathrm{g}\right)$

R016 3 Leach rate (/yr)

RO16 3 Solubility constant

R016 3 Distribution coefficients for daughter Pa-231

R016 3 Contaminated zone $\left(\mathrm{cm}^{* *} 3 / \mathrm{g}\right)$

R016 3 Unsaturated zone $1\left(\mathrm{~cm}^{* *} 3 / \mathrm{g}\right)$

R016 3 Saturated zone $\left(\mathrm{cm}^{* *} 3 / \mathrm{g}\right)$

R016 3 Leach rate (/yr)

R016 3 Solubility constant

R016 3 Distribution coefficients for daughter Pb-210

R016 3 Contaminated zone $\left(\mathrm{cm}^{* *} 3 / \mathrm{g}\right)$

R016 3 Unsaturated zone $1\left(\mathrm{~cm}^{* *} 3 / \mathrm{g}\right)$

R016 3 Saturated zone $\left(\mathrm{cm}^{* *} 3 / \mathrm{g}\right)$

R016 3 Leach rate (/yr)

R016 ${ }^{3}$ Solubility constant

R016 3 Distribution coefficients for daughter Ra-226

R016 3 Contaminated zone $\left(\mathrm{cm}^{* *} 3 / \mathrm{g}\right)$

R016 3 Unsaturated zone $1\left(\mathrm{~cm}^{* *} 3 / \mathrm{g}\right)$

R016 3 Saturated zone $\left(\mathrm{cm}^{* *} 3 / \mathrm{g}\right)$

R016 3 Leach rate (/yr)

RO16 3 Solubility constant

R016 3 Distribution coefficients for daughter Th-230

R016 3 Contaminated zone $\left(\mathrm{cm}^{* *} 3 / \mathrm{g}\right)$

R016 3 Unsaturated zone $1(\mathrm{~cm} * * 3 / \mathrm{g})$

R016 3 Saturated zone $\left(\mathrm{cm}^{* *} 3 / \mathrm{g}\right)$

R016 3 Leach rate (/yr)

RO16 3 Solubility constant

R016 3 Distribution coefficients for daughter U-234

R016 3 Contaminated zone $\left(\mathrm{cm}^{* *} 3 / \mathrm{g}\right)$

R016 3 Unsaturated zone $1\left(\mathrm{~cm}^{* *} 3 / \mathrm{g}\right)$

R016 3 Saturated zone $\left(\mathrm{cm}^{* *} 3 / \mathrm{g}\right)$

$\mathrm{R} 016$ Leach rate (/yr)

RO16 3 Solubility constant

\begin{tabular}{|c|c|}
\hline \multirow{2}{*}{ (1) } & ( \\
\hline & $3.000 \mathrm{E}+01 \quad 3 \quad 3$. \\
\hline \multirow{2}{*}{ not used } & $\begin{array}{l}3.0 \\
3\end{array}$ \\
\hline & \\
\hline $\begin{array}{l}\text { not used } \\
\odot . \odot \odot \odot E+\odot \odot\end{array}$ & 30 \\
\hline \multirow[t]{3}{*}{$\odot . \odot \odot \odot E+\odot \odot$} & \\
\hline & \\
\hline & 3 \\
\hline \multirow{6}{*}{$\begin{array}{l}2 . \odot \odot \odot E+\odot 1 \\
\text { not used } \\
\text { not used } \\
\odot . \odot \odot \odot E+\odot \odot \\
\odot . \odot \odot \odot E+\odot \odot\end{array}$} & $\mathrm{E}+01$ \\
\hline & \\
\hline & 32. \\
\hline & 30. \\
\hline & \\
\hline & 3 \\
\hline \multirow{7}{*}{$\begin{array}{l}5 . \odot \odot \odot E+\odot 1 \\
\text { not used } \\
\text { not used } \\
\odot . \odot \odot \odot E+\odot \odot \\
\odot . \odot \odot \odot E+\odot \odot\end{array}$} & 35 \\
\hline & 35. \\
\hline & 35. \\
\hline & 30. \\
\hline & 30. \\
\hline & \\
\hline & 3 \\
\hline \multirow{7}{*}{$\begin{array}{ll}3 & 1 . \odot \odot \odot E+\odot 2 \\
3 & \text { not used } \\
3 & \text { not used } \\
3 & \odot . \odot \odot \odot E+\odot \odot \\
3 & \odot . \odot \odot \odot E+\odot \odot\end{array}$} & 31. \\
\hline & 31 \\
\hline & 31. \\
\hline & \\
\hline & \\
\hline & \\
\hline & 3 \\
\hline \multirow{7}{*}{$\begin{array}{l}7.000 \mathrm{E}+\Theta 1 \\
\text { not used } \\
\text { not used } \\
\odot . \odot \odot \odot E+\odot \odot \\
\odot . \odot \odot \odot E+\odot \odot\end{array}$} & 37. \\
\hline & 37. \\
\hline & 37. \\
\hline & \\
\hline & 30.6 \\
\hline & \\
\hline & 3 \\
\hline \multirow{7}{*}{$\begin{array}{l}6.000 E+\odot 4 \\
\text { not used } \\
\text { not used } \\
\odot .000 E+\odot \odot \\
\odot .00 \odot E+\odot \odot\end{array}$} & \\
\hline & 36.0 \\
\hline & 36.6 \\
\hline & \\
\hline & $3 \quad \odot . \odot \odot \odot E+\odot \odot$ \\
\hline & \\
\hline & 3 \\
\hline \multirow{5}{*}{$\begin{array}{l}5 . \odot \odot \odot E+\odot 1 \\
\text { not used } \\
\text { not used } \\
\odot .0 \odot \odot E+\odot \odot \\
\odot . \odot \odot \odot E+\odot \odot\end{array}$} & 35. \\
\hline & \\
\hline & . \\
\hline & \\
\hline & \\
\hline
\end{tabular}

\begin{tabular}{|c|c|c|}
\hline & 3 & \\
\hline-- & 3 & DCNUCC (10) \\
\hline-- & 3 & $\operatorname{DCNUCU}(10,1)$ \\
\hline-- & 3 & $\operatorname{DCNUCS}(10)$ \\
\hline $2.911 \mathrm{E}-02$ & 3 & ALEACH (10) \\
\hline not used & $\begin{array}{l}3 \\
3\end{array}$ & SOLUBK $(10)$ \\
\hline & 3 & \\
\hline-- & 3 & DCNUCC ( 1) \\
\hline-- & 3 & $\operatorname{DCNUCU}(1,1)$ \\
\hline-- & 3 & DCNUCS ( 1) \\
\hline $4.352 E-02$ & 3 & ALEACH $(1)$ \\
\hline not used & 3 & SOLUBK( 1$)$ \\
\hline & 3 & \\
\hline & 3 & \\
\hline-- & 3 & DCNUCC ( 4) \\
\hline-- & 3 & $\operatorname{DCNUCU}(4,1)$ \\
\hline-- & 3 & DCNUCS( 4 ) \\
\hline $1.751 \mathrm{E}-02$ & 3 & ALEACH $(4)$ \\
\hline not used & 3 & SOLUBK( 4$)$ \\
\hline & 3 & \\
\hline & 3 & \\
\hline-- & 3 & DCNUCC ( 5) \\
\hline-- & 3 & $\operatorname{DCNUCU}(5,1)$ \\
\hline- & 3 & DCNUCS ( 5) \\
\hline $8.774 \mathrm{E}-03$ & 3 & ALEACH ( 5) \\
\hline not used & 3 & SOLUBK( 5) \\
\hline & $\begin{array}{l}3 \\
3\end{array}$ & \\
\hline - - - & 3 & DCNUCC ( 8) \\
\hline- & 3 & $\operatorname{DCNUCU}(8,1)$ \\
\hline-- & 3 & DCNUCS $(8)$ \\
\hline $1.252 \mathrm{E}-02$ & 3 & ALEACH ( 8) \\
\hline not used & 3 & SOLUBK( 8 ) \\
\hline & 3 & \\
\hline & 3 & \\
\hline-- & 3 & DCNUCC (11) \\
\hline- & 3 & $\operatorname{DCNUCU}(11,1)$ \\
\hline-- & 3 & DCNUCS (11) \\
\hline $1.465 E-05$ & 3 & ALEACH (11) \\
\hline not used & 3 & SOLUBK (11) \\
\hline & 3 & \\
\hline & 3 & \\
\hline- & 3 & DCNUCC (12) \\
\hline-- & 3 & $\operatorname{DCNUCU}(12,1)$ \\
\hline-- & 3 & DCNUCS (12) \\
\hline $.751 E-02$ & 3 & $\operatorname{ALEACH}(12)$ \\
\hline ot used & 3 & SOLUBK (12) \\
\hline
\end{tabular}




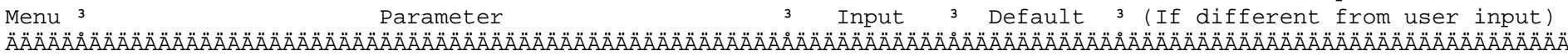
R016 3 Distribution coefficients for daughter U-235

RO16 3 Contaminated zone $\left(\mathrm{cm}^{* *} 3 / \mathrm{g}\right)$

R016 3 Unsaturated zone $1\left(\mathrm{~cm}^{* *} 3 / \mathrm{g}\right)$

R016 3 Saturated zone $\left(\mathrm{cm}^{* *} 3 / \mathrm{g}\right)$

$\mathrm{R} 016$ Leach rate (/yr)

R016 3 Solubility constant

R017 ${ }^{3}$ Inhalation rate $\left(m^{* *} 3 / y r\right)$

R017 3 Mass loading for inhalation $\left(\mathrm{g} / \mathrm{m}^{* *} 3\right)$

R017 3 Exposure duration

R017 3 Shielding factor, inhalation

R017 3 Shielding factor, external gamma

R017 3 Fraction of time spent indoors

R017 3 Fraction of time spent outdoors (on site)

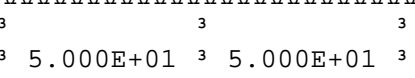

3 not used $35.000 \mathrm{E}+013$

3 not used 3 5.000E+01 3

$\odot . \odot \odot \odot E+\odot \odot \quad 3 \quad 0.0 \odot \odot \mathrm{E}+\odot \odot \quad 3$

$0.000 \mathrm{E}+00^{3} \quad \odot .000 \mathrm{E}+00^{3}$ 3

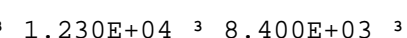

6. $000 \mathrm{E}-044^{3} 1.000 \mathrm{E}-044^{3}$

$2.500 \mathrm{E}+0133.000 \mathrm{E}+013$

$1.000 \mathrm{E}+00$ 3 $4.000 \mathrm{E}-013$

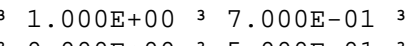

๑. $.000 \mathrm{E}+00$ 3 $5.000 \mathrm{E}-01{ }^{3}$

$3.800 \mathrm{E}-02 \quad 3 \quad 2.500 \mathrm{E}-01 \quad 3$

$1.000 \mathrm{E}+00 \quad 3 \quad 1.000 \mathrm{E}+00 \quad 3$

R017 3 Shape factor flag, external gamma

R017 3 Radii of shape factor array (used if FS = -1):

R017 3 Outer annular radius $(\mathrm{m})$, ring 1:

$\mathrm{R} 017$ O 3 Outer annular radius $(\mathrm{m})$, ring 2 :

$\mathrm{R} 017^{3}$ Outer annular radius $(\mathrm{m})$, ring 3

$\mathrm{R} 017$ O 3 Outer annular radius $(\mathrm{m})$, ring 4 :

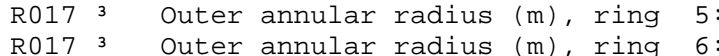

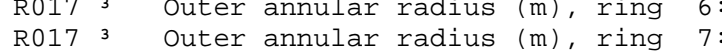

R017 3 Outer annular radius (m), ring 8:

$\mathrm{R} 017^{3} \quad$ Outer annular radius $(\mathrm{m})$, ring 9

R017 3 Outer annular radius $(\mathrm{m})$, ring 10

$\mathrm{R} 017$ 3 $\quad$ Outer annular radius $(\mathrm{m})$, ring 11:

$\mathrm{R} 017^{3}$ Outer annular radius (m), ring 12:

R017 3 Fractions of annular areas within AREA:

$\mathrm{R} 017$ 3 Ring 1

$\begin{array}{llll}\mathrm{R} 017 & 3 & \text { Ring } & 2 \\ \mathrm{R} 017 & 3 & \text { Ring } & 3\end{array}$

$\begin{array}{llll}\mathrm{R} 017 & 3 & \text { Ring } & 3 \\ \mathrm{R} 017 & 3 & \text { Ring } & 4\end{array}$

R017 3 Ring 5

R017 3 Ring 6

R017 3 Ring 7

R017 3 Ring 8

R017 3 Ring 9

R017 3 Ring 10

$\begin{array}{llll}R 017 & 3 & \text { Ring } 11 \\ \text { R017 } & 3 & \text { Ring } 12\end{array}$

00183 Fruits, vegetables and grain consumption ( ${ }^{3} \mathrm{~g} / \mathrm{yr}$ )

R018 3 Leafy vegetable consumption ( $\mathrm{kg} / \mathrm{yr}$ )

R018 3 Milk consumption ( $\mathrm{L} / \mathrm{yr}$ )

R018 3 Meat and poultry consumption ( $\mathrm{kg} / \mathrm{yr}$ )

R018 3 Fish consumption ( $\mathrm{kg} / \mathrm{yr}$ )

R018 3 Other seafood consumption ( $\mathrm{kg} / \mathrm{yr}$ )

R018 3 Soil ingestion rate ( $/ / y r)$

R018 3 Drinking water intake (L/yr)
3 not used $35.000 \mathrm{E}+01^{3}$

3 not used $37.071 \mathrm{E}+013$

3 not used $30.000 \mathrm{E}+00^{3}$

3 not used $30.000 \mathrm{E}+00^{3}$

3 not used $30.000 \mathrm{E}+0 \odot^{3}$

3 not used $30.00 \Theta E+00$

3 not used 3 .

3 not used $30.000 \mathrm{E}+0 \mathrm{O}^{3}$

3 not used $30.000 \mathrm{E}+\odot \odot$

3 not used $30.000 \mathrm{E}+0 \odot$

3 not used $30.000 \mathrm{E}+00$

3 not used 3 $0.000 \mathrm{E}+00$

3

3 not used $31.000 \mathrm{E}+00^{3}$

3 not used $32.732 \mathrm{E}-013$

3 not used $30.000 \mathrm{E}+0{ }^{3}$

not used $30.000 \mathrm{E}+\odot \odot^{3}$

3 not used $30.000 \mathrm{E}+00^{3}$

3 not used $30.000 \mathrm{E}+0 \odot^{3}$

3 not used $30.000 \mathrm{E}+00^{3}$

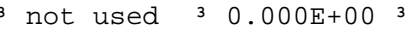

3 not used $30.000 \mathrm{E}+0 \odot 3$

3 not used $3 \quad 0.000 \mathrm{E}+\odot{ }^{3}$

not used $3 \quad \odot .000 \mathrm{E}+\odot \odot^{3}$

not used $30.000 \mathrm{E}+0 \odot^{3}$

not used 3 1.600E+02 3 not used 3 1.400E+01 3

not used 3 9.200E+01 3

3 not used $36.300 E+013$

3 not used $35.400 E+00^{3}$

3 not used 3 9.000E-01 3

$\begin{array}{lll}1.752 \mathrm{E}+02 & 3 & 3.650 \mathrm{E}+01 \\ 3\end{array}$

3 not used $35.100 \mathrm{E}+023$ not used $0.000 \mathrm{E}+00$
Used by RESRAD

3 Parameter

\section{Name}

Nǟ̈ÄÄÄÄÄÄÄÄÄÄÄ

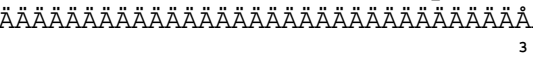

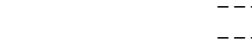

$1.751 \mathrm{E}-02$

not used

- - -

$-\cdot$

$-$

$--$

$--$

$>\odot$ shows circular AREA.

$-$

- - -

$--$

$--$

$--$

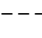

$--$

$---$

$-\cdot$

$--$

$--$

- - -

$--$

- - -

$--$

$--$

$---$

$--$

- - -

$--$

$--$

$--$

$--$

$--$
$3 \operatorname{DCNUCC}(13)$

$3 \operatorname{DCNUCU}(13,1)$

3 DCNUCS(13)

ALEACH (13)

3 INHALR

3 MLINH

3 ED

3 SHF3

SHF1

FIND

3 FS

RAD_SHAPE( 1$)$

3 RAD_SHAPE ( 2)

3 RAD_SHAPE( 3 )

3 RAD_SHAPE ( 4 )

3 RAD SHAPE ( 5 )

3 RAD_SHAPE ( 6 )

3 RAD_SHAPE ( 7 )

3 RAD_SHAPE( 8 )

3 RAD_SHAPE ( 9)

3 RAD_SHAPE (10)

3 RAD_SHAPE (11)

3 FRACA ( 1)

3 FRACA ( 2)

3 FRACA ( 3 )

3 FRACA ( 4$)$

3 FRACA ( 5)

3 FRACA ( 6)

3 FRACA ( 7$)$

3 FRACA ( 8)

3 FRACA ( 9)

$\operatorname{FRACA}(10)$

FRACA (11)

$3 \operatorname{FRACA}(12)$

DIET(1)

3 DIET (3)

$3 \operatorname{DIET}(4)$

3 DIET (5)

$\begin{array}{ll}3 & \operatorname{DIET}(5) \\ 3 & \operatorname{DIET}(6)\end{array}$

$3 \operatorname{DIET}(6)$

3 SOIL 
R018 3 Contamination fraction of drinking water
R018 3 Contamination fraction of household water

R018 3 Contamination fraction of livestock water

R018 3 Contamination fraction of irrigation water

R018 3 Contamination fraction of aquatic food

R018 3 Contamination fraction of plant food

R018 3 Contamination fraction of meat

R018 3 Contamination fraction of milk 3

R019 3 Livestock fodder intake for meat ( $\mathrm{kg} /$ day)

R019 3 Livestock fodder intake for milk ( $\mathrm{kg} /$ day)

R019 3 Livestock water intake for meat (L/day)

R019 3 Livestock water intake for milk (L/day)

R019 3 Livestock soil intake ( $\mathrm{kg} / \mathrm{day}$ )

R019 3 Mass loading for foliar deposition $\left(\mathrm{g} / \mathrm{m}^{* *} 3\right)$

R019 3 Depth of soil mixing layer $(m)$

R019 3 Depth of roots $(m)$

R019 3 Drinking water fraction from ground water

R019 3 Household water fraction from ground water

R019 3 Livestock water fraction from ground water

R019 3 Irrigation fraction from ground water

3 not used $31.000 \mathrm{E}+00^{3}$

3 not used $31.000 \mathrm{E}+0 \odot^{3}$

3 not used $31.000 \mathrm{E}+00^{3}$

3 not used $31.000 \mathrm{E}+003$

3 not used 3 5.000E-01 3

3 not used $3-1$

3 not used $3-1$

3 not used $3-1$

3

3 not used $36.800 \mathrm{E}+01^{3}$

3 not used 3 5.500E+01 3

3 not used $35.000 \mathrm{E}+013$

not used $1.600 \mathrm{E}+02^{3}$

not used 3 5.000E-01

$1.000 \mathrm{E}-04$

$1.500 \mathrm{E}-01$ 3 $1.500 \mathrm{E}-013$

not used $39.00 \odot \mathrm{E}-01$

3 not used $31.000 \mathrm{E}+0 \odot^{3}$

3 not used $31.000 \mathrm{E}+00^{3}$

3 not used $31.000 \mathrm{E}+00^{3}$

not used 3 1. $000 \mathrm{E}+00^{3}$

3

R19B 3 Wet weight crop yield for Non-Leafy $\left(\mathrm{kg} / \mathrm{m}^{* *} 2\right)$

R19B 3 Wet weight crop yield for Leafy $\left(\mathrm{kg} / \mathrm{m}^{* *} 2\right)$

R19B 3 Wet weight crop yield for Fodder $\left(\mathrm{kg} / \mathrm{m}^{* *} 2\right)$

R19B 3 Growing Season for Non-Leafy (years)

R19B 3 Growing Season for Leafy (years)

R19B 3 Growing Season for Fodder (years)

R19B 3 Translocation Factor for Non-Leafy

R19B 3 Translocation Factor for Leafy

R19B 3 Dry Foliar Interception Fraction for Non-Leafy

$\begin{array}{llll}\text { R19B } & 3 & \text { Dry Foliar Interception Fraction for Non-Leafy } \\ \text { R19B } & 3 & \text { Dry Foliar Interception Fraction for Leafy }\end{array}$

R19B 3 Dry Foliar Interception Fraction for Fodder

R19B 3 wet Foliar Interception Fraction for Non-Leafy

R19B 3 Wet Foliar Interception Fraction for Leafy
R19B 3 Wet Foliar Interception Fraction for Fodder

R19B 3 Weathering Removal Constant for Vegetation

C14 ${ }^{3} \mathrm{C}-12$ concentration in water $(\mathrm{g} / \mathrm{cm} * * 3)$

C14 3 C-12 concentration in contaminated soil $(\mathrm{g} / \mathrm{g})$

C14 3 Fraction of vegetation carbon from soil

C14 3 Fraction of vegetation carbon from air

C14 3 C-14 evasion layer thickness in soil (m)

C14 ${ }^{3}$ C-14 evasion flux rate from soil ( $1 / \mathrm{sec}$ )

C14 3 C-12 evasion flux rate from soil ( $1 / \mathrm{sec})$

C14 3 Fraction of grain in beef cattle feed

C14 3 Fraction of grain in milk cow feed

C14 3 DCF correction factor for gaseous forms of C14

$$
3
$$

STOR 3 Storage times of contaminated foodstuffs (days):

3 not used 3 7.000E-01 3

not used 3 1.500E+०० 3

not used $31.100 \mathrm{E}+0 \odot^{3}$

3 not used $31.700 \mathrm{E}-01^{3}$

3 not used 3 2.500E- 013

3 not used 3 8.000E-02 3

3 not used 3 1.000E- 013

3 not used $31.000 E+0{ }^{3}$

3 not used 3 1.000E $+00^{3}$

not used 3 2.500E-01 3

3 not used 3 2.500E-01 3

not used $32.500 \mathrm{E}-01^{3}$

not used 3 2.500E-01 3

3 not used $32.500 \mathrm{E}-01^{3}$

3 not used $32.500 \mathrm{E}-01^{3}$

not used $32.000 \mathrm{E}+013$

3 not used $32.000 \mathrm{E}-05^{3}$

not used 3 3.000E- $022^{3}$

not used 3 2.000E- $022^{3}$

3 not used 3 9.800E-01 3

3 not used 3 3.000E-01 3

3 not used 3 7.000E-07 3

3 not used 3 1.000E-10 3

3 not used 3 8.000E-013

3 not used 3 2.000E-01 3

3 not used 3 8.894E+01 3 3

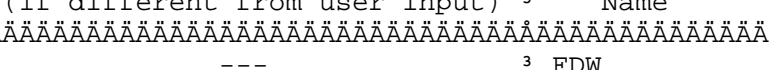

- - $\quad 3$ FDW

$3 \mathrm{FHHW}$
$3 \mathrm{FLW}$

$\begin{array}{ll}3 & \text { FLW } \\ --- & 3 \\ \text { FIRW }\end{array}$

$\begin{array}{ll}-- & 3 \text { FIRW } \\ -.- & 3 \text { FR9 }\end{array}$

3 FPLANT

3 FMEAT

- - 3 FMILK

$\begin{array}{ll}--- & 3 \text { LFI5 } \\ --- & 3 \text { LFI6 }\end{array}$

- - 3 LWI5

- - 3 LWI6

-.- 3 LSI

-.- 3 MLFD

$\begin{array}{ll}--- & 3 \text { DM } \\ --- & 3 \\ --- & 3\end{array}$

-. 3 FGWDW

-. 3 FGWHH

$\begin{array}{lll}3 & \text { FGWLW } \\ 3 & \text { FGWIR }\end{array}$

$Y V(1)$

$Y V(2)$

$3 \mathrm{YV}(3)$

3 TE (1)

$3 \mathrm{TE}(2)$

3 TE(3)

$3 \operatorname{TIV}(1)$

3 TIV (2)

3 RDRY (1)

3 RDRY (1)

3 RDRY (2)

$3 \operatorname{RDRY}(3)$

3 RWET (1)

3 RWET (2)

3 RWET (3)

3 WLAM

3 C12WTR

3 C12CZ

3 CSOIL

3 CAIR

3 DMC

3 EVSN

3 REVSN

3 AVFG4

3 AVFG5

3 CO2F 
STOR 3

Fruits, non-leafy vegetables, and grain $1.400 \mathrm{E}+01^{3} 1.400 \mathrm{E}+01^{3}$

Leafy vegetables

STOR 3 Meat and poultry

STOR ${ }^{3}$ Fish

STOR 3 Crustacea and mollusks

STOR 3 Well water

STOR 3 Surface water

STOR 3 Livestock fodder

R०21 3 Thickness of building foundation $(\mathrm{m})$

R०21 3 Bulk density of building foundation $\left(\mathrm{g} / \mathrm{cm}^{* *} 3\right)$

R021 3 Total porosity of the cover material

$1.000 \mathrm{E}+0 \odot^{3} 1.000 \mathrm{E}+0 \odot^{3}$

$\begin{array}{llll}3 & 1.000 \mathrm{E}+00^{3} & 1.000 \mathrm{E}+00^{3} & 3\end{array}$

$\begin{array}{llll}2.000 \mathrm{E}+01 & 3 & 2.000 \mathrm{E}+01 & 3 \\ 7 & & \end{array}$

3 $7.000 \mathrm{E}+0 \odot$ 3 $7.000 \mathrm{E}+0 \odot \quad 3$

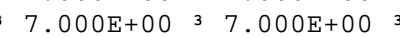

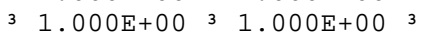

$\begin{array}{lll}3 & 1.00 \odot \mathrm{E}+\odot \odot \quad 3 & 1.000 \mathrm{E}+\odot \odot \quad 3\end{array}$

$\begin{array}{lllll}3 & 4.500 \mathrm{E}+01 & 3 & 4.500 \mathrm{E}+01 & 3 \\ 3 & & 3 & \end{array}$

3 not used $31.500 \mathrm{E}-01^{3}$

3 not used $32.400 E+00 \quad 3$

3 not used 34 . $000 \mathrm{E}-013$

3 not used 3 1.000E-013

Ro21 3 Total porosity of the building foundation

3 not used $31.000 \mathrm{E}-01^{3}$

R021 3 Volumetric water content of the cover material 3 not used $35.000 \mathrm{E}-022^{3}$

R021 3 Volumetric water content of the foundation

R021 3 Diffusion coefficient for radon gas $(\mathrm{m} / \mathrm{sec})$ :

$\mathrm{R} 021^{3}$ in cover material

R021 3 in foundation material

$\mathrm{R} 021^{3}$ in contaminated zone soil

R021 3 Radon vertical dimension of mixing $(\mathrm{m})$

R021 3 Average building air exchange rate $(1 / \mathrm{hr})$

R021 3 Height of the building (room) (m)

R०21 3 Building interior area factor

R021 3 Building depth below ground surface $(\mathrm{m})$

R०21 3 Emanating power of $\mathrm{Rn}-222$ gas

3 not used 3 3. $3.000 \mathrm{E}-02_{3}^{3}$

3 not used $32.000 \mathrm{E}-06^{3}$

3 not used $33.000 \mathrm{E}-073$

3 not used $32.000 \mathrm{E}-06^{3}$

3 not used $32.000 \mathrm{E}+0 \Theta^{3}$

3 not used 35 . $000 \mathrm{E}-01^{3}$

3 not used $32.500 E+00^{3}$

3 not used 3 (.500E+๑๑

not used $30.000 \mathrm{E}+0 \mathrm{O}^{3}$

3 not used $3-1.000 \mathrm{E}+00^{3}$

3 not used $32.500 \mathrm{E}-01^{3}$

3 not used $31.500 \mathrm{E}-013$

3

TITL 3 Number of graphical time points

TITL 3 Maximum number of integration points for dose

TITL 3 Maximum number of integration points for risk 33043

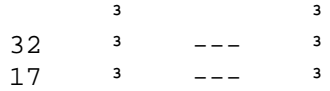

\begin{tabular}{|c|c|c|}
\hline- & 3 & STOR_T(1) \\
\hline$\ldots$ & 3 & STOR_T (2) \\
\hline - - - & 3 & STOR_T (3) \\
\hline- & 3 & STOR_T (4) \\
\hline--- & 3 & STOR_T (5) \\
\hline-- & 3 & STOR_T (6) \\
\hline - & 3 & STOR_T (7) \\
\hline - & 3 & STOR_T (8) \\
\hline - & $\begin{array}{l}3 \\
3\end{array}$ & STOR_T (9) \\
\hline - - & 3 & FLOOR1 \\
\hline - & 3 & DENSFL \\
\hline & 3 & TPCV \\
\hline$\ldots$ & 3 & TPFL \\
\hline - & 3 & PH2OCV \\
\hline - & $\begin{array}{l}3 \\
3\end{array}$ & PH2OFL \\
\hline - - & 3 & DIFCV \\
\hline - - & 3 & DIFFL \\
\hline - - & 3 & DIFCZ \\
\hline - & 3 & HMIX \\
\hline & 3 & REXG \\
\hline - - & 3 & HRM \\
\hline - & 3 & FAI \\
\hline & 3 & DMFL \\
\hline & 3 & EMANA(1) \\
\hline & $\begin{array}{l}3 \\
3\end{array}$ & EMANA(2) \\
\hline- & 3 & NPTS \\
\hline & 3 & LYMAX \\
\hline & 3 & KYMAX \\
\hline
\end{tabular}

Summary of Pathway Selections

Pathway 3 User Selection

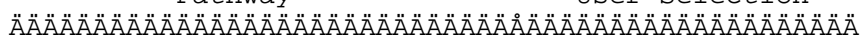

1 - - external gamma ${ }_{3} \quad$ active

2 - - inhalation (W/o radon) ${ }^{3} \quad$ active

3 - - plant ingestion 3 suppressed

4 -- meat ingestion 3 suppressed

5 -- milk ingestion 3 suppressed

6 - - aquatic foods 3 suppressed

7 -- drinking water 3 suppressed

8 - - soil ingestion 3 active

9 -- radon 3 suppressed

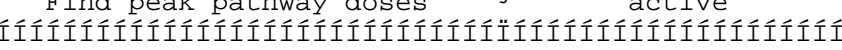


1RESRAD, Version $6.22 \quad$ T« Limit $=0.5$ year Summary : RESRAD Default Parameters

Contaminated Zone Dimensions ÄÄÄÄÄÄÄÄÄÄÄÄÄÄÄÄÄÄÄÄÄÄÄÄÄ Area: 56250.00 square meters

Thickness: $\quad 0.15$ meters Cover Depth: $\quad 0.00$ meters

Total Dose TDOSE(t), mrem/yr

Basic Radiation Dose Limit $=2.500 \mathrm{E}+01 \mathrm{mrem} / \mathrm{yr}$

Total Mixture Sum $\mathrm{M}(\mathrm{t})=$ Fraction of Basic Dose Limit Received at Time $(\mathrm{t})$

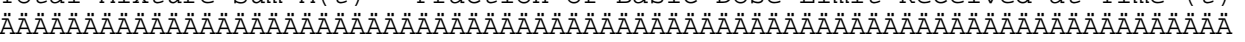

$\mathrm{t}$ (years): $\begin{array}{lllllllll}0.000 \mathrm{E}+00 & 1.000 \mathrm{E}+00 & 3.000 \mathrm{E}+00 & 1.000 \mathrm{E}+01 & 7.000 \mathrm{E}+01 & 1.000 \mathrm{E}+02 & 3.000 \mathrm{E}+02 & 1.000 \mathrm{E}+03\end{array}$

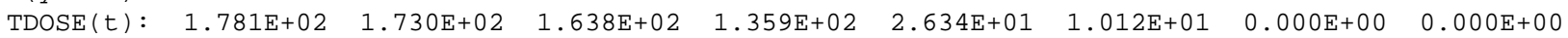

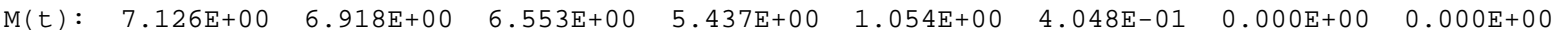

OMaximum TDOSE $(\mathrm{t}): 1.781 \mathrm{E}+02 \mathrm{mrem} / \mathrm{yr}$ at $\mathrm{t}=0.000 \mathrm{E}+00$ years 
Total Dose Contributions $\operatorname{TDOSE}(i, p, t)$ for Individual Radionuclides (i) and Pathways ( $p$ )

As mrem/yr and Fraction of Total Dose At $t=0.000 \mathrm{E}+00$ years

\begin{tabular}{|c|c|c|}
\hline & Grou & \\
\hline adio- & ÄÄÄÄÄÄÄÄÄ & ÄÄÄÄÄÄÄ \\
\hline $\begin{array}{l}\text { Nuclide } \\
\text { ÄÄÄÄÄÄÄÄ }\end{array}$ & 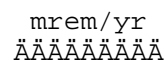 & $\begin{array}{l}\text { fract. } \\
\ddot{A} A ̈ A ̈ A ̈ A ̈ A ̈\end{array}$ \\
\hline Co- 60 & $2.954 \mathrm{E}+00$ & 0.0166 \\
\hline Cs -137 & $1.719 \mathrm{E}+02$ & $\odot .9649$ \\
\hline Pu-238 & $6.750 \mathrm{E}-05$ & $\odot . \odot \odot \odot \odot$ \\
\hline Pu-239 & $3.988 \mathrm{E}-04$ & $\odot . \odot \odot \odot \odot$ \\
\hline$S b-125$ & $4.004 \mathrm{E}-01$ & $\odot .0 \odot 22$ \\
\hline Sr -90 & $1.746 \mathrm{E}-01$ & $\odot .0 \odot 10$ \\
\hline Íííí́íí & Ííííííí́í & Íííííí \\
\hline Total & $1.754 \mathrm{E}+02$ & 0.9847 \\
\hline
\end{tabular}

Inhalation Water Independent Pathways (Inhalation excludes radon)
Radon

mrem/yr fract.
ÄÄ̈̈Ӓ̈̈̈̈̈̈ ÄÄÄÄÄ̈

5.316E- 05 0.000๑

$2.022 \mathrm{E}-03 \quad 0.0000$

$1.948 \mathrm{E}-010.0011$

$6.727 \mathrm{E}-010.0038$

$2.806 \mathrm{E}-06 \quad 0.0000$

1.108E-02 0.0001

8.807E-01 0.0049 A ÄÄÄÄÄÄÄÄ ÄÄÄÄÄÄ ÄÄÄÄÄÄÄÄÄ ÄÄÄÄÄÄ $\begin{array}{llllll}.000 \mathrm{E}+00 & 0.0000 & 0.000 \mathrm{E}+00 & 0.0000 & 0.000 \mathrm{E}+00 & 0.0000 \\ .000 \mathrm{E}+00 & 0.0000 & 0.000 \mathrm{E}+0 \odot & 0.000 \odot & 0.000 \mathrm{E}+00 & 0.0000\end{array}$ 0.0000 . . $0.000 \mathrm{E}+00 \quad 0.0000$ $0.000 \mathrm{E}+00 \mathrm{0}, 0.0000$ $0.000 E+00 \quad 0.0000$ $\odot .000 \mathrm{E}+00 \quad 0.0000$ $0.000 \mathrm{E}+00 \quad 0.0000$ $0.000 \mathrm{E}+000.0000$ $\odot . \odot \odot \odot E+\odot \odot \quad \odot . \diamond \odot \odot \odot$ $\begin{array}{lll}0.000 E+0 \odot & 0.0000 \\ 0.000 E+0 \odot & 0.0000\end{array}$ Íííííííi ííííí ííííííí ííííí

Milk

Soil

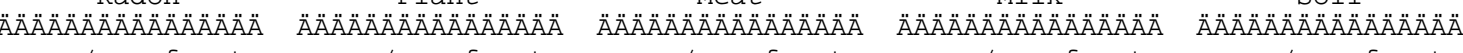
mrem/yr fract. mrem/yr fract. mrem/yr fract. mrem/yr fract. AAAAAAAAA AAAAAA $0.000 \mathrm{E}+00$ - 0.0000 $0.000 \mathrm{E}+00 \quad 0.0000$ $0.000 \mathrm{E}+0 \odot \quad 0.0000$ $0.000 \mathrm{E}+0 \odot$ ०. 0.0000 $0.000 \mathrm{E}+\odot \odot \odot .00 \odot 0$ ๑. $000 \mathrm{E}+00$ 0.0000 $\odot .0 \odot \odot \mathrm{E}+\odot \odot \odot . \odot \odot \odot$ mrem/yr fract. ÄÄÄÄÄÄÄÄÄ ÄÄÄÄÄÄ $1.033 \mathrm{E}-03 \quad 0.0000$ $5.016 \mathrm{E}-010.0028$ $2.516 \mathrm{E}-010.0014$ $8.783 \mathrm{E}-010.0049$ $1.168 \mathrm{E}-04 \quad 0.0000$ 2. $047 \mathrm{E}-010.0011$ $1.837 \mathrm{E}+0 \odot \quad 0.0103$

Total Dose Contributions $\operatorname{TDOSE}(i, p, t)$ for Individual Radionuclides (i) and Pathways ( $p$ )

As $\mathrm{mrem} / \mathrm{yr}$ and Fraction of Total Dose At $t=0.000 \mathrm{E}+0 \odot$ years

\section{$\odot$} Water Dependent Pathways

water Radio- ÄÄÄÄÄÄÄÄÄÄÄÄÄÄÄÄÄ Nuclide mrem/yr fract.

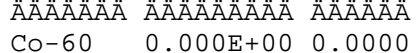
CS-137 $0.000 \mathrm{E}+0 \odot \quad 0.000 \odot$ Pu-238 $0.000 \mathrm{E}+000.0000$ Pu-239 $0.000 \mathrm{E}+0 \odot \quad 0.000 \odot$ $\mathrm{Sb}-125 \quad 0.000 \mathrm{E}+00 \quad 0.000 \odot$ Sr-90 $0.000 \mathrm{E}+00 \quad 0.0000$ Íííííi íííííííi ííííí Total $0.000 \mathrm{E}+000.0000$ Wate
Radon Plant

Meat ÄÄÄÄÄÄÄÄÄÄÄÄÄ $\mathrm{mrem} / \mathrm{yr}$ fract. ÄÄÄÄÄÄÄÄÄÄÄÄÄÄ mrem/yr fract.
ÄÄÄÄÄÄÄÄ ÄÄÄÄÄÄ

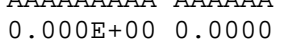
$0.000 \mathrm{E}+0 \odot \quad 0.000 \odot$ $\odot .000 \mathrm{E}+0 \odot \quad 0.000 \odot$ $0.000 \mathrm{E}+000.0000$ $0.000 \mathrm{E}+00 \quad 0.0000$

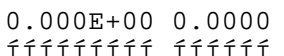
ÄÄÄÄÄÄÄÄÄÄÄÄÄÄÄÄ ÄÄÄÄÄÄÄÄÄÄÄÄÄÄÄA mrem/yr fract ÄÄÄÄÄÄÄÄÄ ÄÄÄÄÄÄA $\odot . \odot \odot \odot E+\odot \odot \quad \odot . \odot \odot \odot \odot$ $\odot .000 \mathrm{E}+0 \odot \quad 0.000 \odot$ $0.000 \mathrm{E}+00 \quad 0.0000$ $0.000 \mathrm{E}+00 \quad 0.0000$ $0.000 \mathrm{E}+00 \quad 0.0000$ $0.00 \odot E+0 \odot \quad 0.0000$ Iííííííi ííííi $\mathrm{mrem} / \mathrm{yr}$ fract. ÄÄÄÄÄÄÄÄÄ ÄÄÄÄÄÄ $\odot .0 \odot \odot E+\odot \odot \quad \odot . \odot \odot \odot \odot$ $0.000 \mathrm{E}+0 \odot \quad 0.0000$ $0.000 \mathrm{E}+00 \quad 0.0000$ $0.000 \mathrm{E}+00 \quad 0.0000$ $\odot .000 \mathrm{E}+0 \odot \quad \odot .0000$ $\odot .000 \mathrm{E}+00 \quad 0.0000$ íííííííí ííííí ÄÄÄÄÄÄÄÄÄ ÄÄÄÄÄÄ $\odot .000 \mathrm{E}+0 \odot \quad 0.0000$ $0.000 \mathrm{E}+00 \quad 0.0000$ $0.000 \mathrm{E}+0 \odot \quad 0.0000$ $\odot .000 \mathrm{E}+0 \odot \quad 0.000 \odot$ $0.000 \mathrm{E}+00 \quad 0.0000$ $\odot . \odot \odot \odot E+\odot \odot \quad \odot . \odot \odot \odot \odot$ ííííííí ííííí $0.000 E+\odot \odot \quad 0.000 \odot$
Milk

All Pathways* Аล̈ÄÄÄÄÄÄÄÄÄÄÄÄÄÄ ÄÄÄÄÄÄÄÄÄÄÄÄÄÄÄÄ $\mathrm{mrem} / \mathrm{yr}$ fract. AAAAAAAAA ÄÄÄÄÄA $0.000 \mathrm{E}+00 \quad 0.0000$ $0.000 \mathrm{E}+0 \odot \quad 0.0000$ $.000 E+0 \odot \quad 0.0000$ $0.000 \mathrm{E}+00 \quad 0.0000$ $0.000 \mathrm{E}+0 \odot \quad 0.0000$ $0.000 \mathrm{E}+000.0000$ Íííííííí ííííí $0.000 \mathrm{E}+000.0000$ mrem/yr fract. ÄÄÄÄÄÄÄÄÄ ÄÄÄÄÄÄ $2.955 \mathrm{E}+00 \quad 0.0166$ $1.724 \mathrm{E}+02 \quad 0.9678$ $4.465 \mathrm{E}-010.0025$ $1.551 \mathrm{E}+00 \quad 0.0087$ $4.005 \mathrm{E}-010.0022$ $3.904 \mathrm{E}-01 \quad 0.0022$ Iííííííi ííííi $1.781 \mathrm{E}+021.0000$ 
Total Dose Contributions TDOSE $(i, p, t)$ for Individual Radionuclides (i) and Pathways ( $p$ )

As mrem/yr and Fraction of Total Dose At $t=1.000 \mathrm{E}+00$ years

$\odot$ Nuclide mrem/yr fract.

AAAAAAÄ ÄÄÄÄÄÄÄÄ ÄÄÄÄÄA

$\begin{array}{lll}C 0-60 & 2.582 \mathrm{E}+0 \odot & 0.0149 \\ \mathrm{CS}-137 & 1.675 \mathrm{E}+02 & 0.9686\end{array}$

$\mathrm{Pu}-238 \quad 6.693 \mathrm{E}-05 \quad 0.0000$

Pu-239 3.983E-04 0.0000

$\mathrm{Sb}-125 \quad 3.825 \mathrm{E}-03 \quad 0.0000$

$\mathrm{Sr}-90 \quad 1.654 \mathrm{E}-01 \quad 0.0010$

Íííííí íííííííi ííííí water Independent Pathways (Inhalation excludes radon)
Radon

Inhalation

Milk

Soil

\section{mrem/yr fract. \\ AАAAAAAAAAÄÄÄÄA AAAAAAAAAÄÄÄÄÄ} $\mathrm{mrem} / \mathrm{yr}$ fract. ÄÄÄÄÄÄÄÄÄ̈̈̈̈̈̈̈̈̈̈̈̈̈̈
mrem/yr fract. ÄÄÄÄÄÄÄÄ ÄÄÄÄÄÄ 4.626E-05 0.0000 $1.961 \mathrm{E}-03 \quad 0.0000$ mrem/yr fract

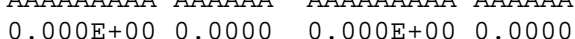
$0.000 \mathrm{E}+00$ 0. 0000 $0.000 E+00$ 0.0000 $0.000 E+00 \quad 0.0000$ $6.679 E-01$ $6.679 \mathrm{E}-010.0039$ $\begin{array}{ll}2.667 E-08 & 0.0000 \\ 1.044 E-02 & 0.0001\end{array}$ $\begin{array}{ll}\text { 1.044E-02 } & 0.0001 \\ \text { ÍÍÍÍÍÍÍ ÍÍÍÍI }\end{array}$ $0.000+\bigcirc \odot 0.0000$ $0.000 \mathrm{E}+00 \quad 0.0000$ $\odot .000 \mathrm{E}+0 \odot \quad 0.000 \odot$ $\odot .000 \mathrm{E}+00 \quad 0.0000$ $0.000 \mathrm{E}+00 \quad 0.0000$ $0.000 \mathrm{E}+00 \quad 0.0000$ $0.000 \mathrm{E}+000.0000$

$0.000 \mathrm{E}+00 \quad 0.0000$ $\odot .00 \odot \mathrm{E}+0 \odot$ $0.000 \odot$

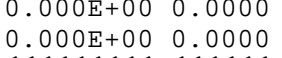
$0.000 \mathrm{E}+00 \quad 0.0000$ Ííííííí ííííi IIIIIIII Íííí

$0.000 \mathrm{E}+000.0000$

$0.000 \mathrm{E}+000.0000$

Total Dose Contributions $\operatorname{TDOSE}(i, p, t)$ for Individual Radionuclides (i) and Pathways $(p)$

As $\mathrm{mrem} / \mathrm{yr}$ and Fraction of Total Dose At $t=1.000 \mathrm{E}+\odot \odot$ years

\section{$\odot$} Water Dependent Pathways

Water Fish Radon Plant Meat

Milk

All Pathways* Radio - ÄÄÄÄÄÄÄÄÄÄÄÄÄÄÄÄ ÄÄÄÄÄÄÄÄÄÄÄÄÄÄÄÄ ÄÄÄÄÄÄÄÄÄÄÄÄÄÄÄÄ ÄÄÄÄÄÄÄÄÄÄÄÄÄÄÄÄ

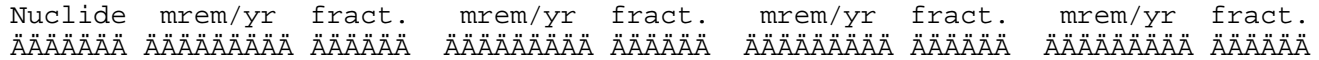

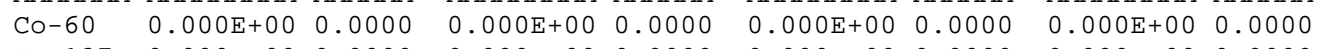

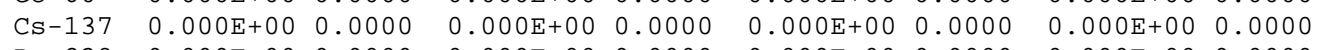
PU-238 $0.000 E+000.0000$ 更 Pu-239 $0.000 \mathrm{E}+00$ 0.0000 $0.000 \mathrm{E}+00$ - 0.0000

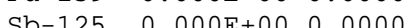
$\mathrm{Sr}-90 \quad 0.000 \mathrm{E}+00 \quad 0.0000$

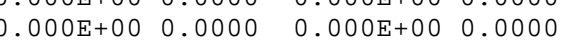
$\odot .000 \mathrm{E}+\odot \odot \quad 0.0000$ $\odot . \odot \odot \odot E+\odot \odot \quad \odot . \odot \odot \odot \odot$

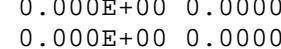

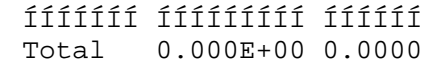

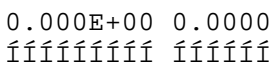
$\begin{array}{lll}0.000 \mathrm{E}+00 & 0.0000 \\ 0.000 \mathrm{E}+00 & 0.0000\end{array}$ ÄÄล̈ÄÄÄÄÄÄÄÄÄÄÄÄ mrem/yr fract. ÄÄÄÄÄÄÄÄÄÄÄÄÄÄÄ
mrem/yr fract. $0.000 \mathrm{E}+00$ 0. 0000 $\odot .00 \odot \mathrm{E}+\odot \odot \quad \odot .00 \odot \odot$ $0.000 \mathrm{E}+00 \quad 0.0000$ AAAAAAAAA AAAAAAÁ $0.000 \mathrm{C}+00$ (0.0000 $0.000 \mathrm{E}+000.0000$ $0.000 \mathrm{E}+000.0000$ $\odot .000 \mathrm{E}+0 \odot \quad 0.0000$ $0.000 \mathrm{E}+00 \quad 0.0000$ $0.000 \mathrm{E}+0 \odot 0.0000$ íííííííí ííííí́ $0.000 E+00 \quad 0.0000$ $0.000 \mathrm{E}+0 \odot 0.0000$ Íííííííí ííííí $\odot$ * Sum of all water independent and dependent pathways.

Аล̈ÄÄÄÄÄÄÄÄÄÄÄÄÄ mrem/yr fract. ÄÄÄÄÄÄÄÄÄ ÄÄÄÄÄÄ $2.583 E+00 \quad 0.0149$ $1.680 \mathrm{E}+02 \quad 0.9715$ $4.398 E-010.0025$ $\begin{array}{lll}1.540 E+00 & 0.0089\end{array}$ $3.826 \mathrm{E}-03 \quad 0.0000$ $3.687 \mathrm{E}-01 \quad 0.0021$ Íííííííi ííííi $1.730 \mathrm{E}+021.0000$ 
Total Dose Contributions $\operatorname{TDOSE}(i, p, t)$ for Individual Radionuclides (i) and Pathways ( $p$ )

As mrem/yr and Fraction of Total Dose At $t=3.000 \mathrm{E}+00$ years

$\odot$ Ground Inhalation Water Independent Pathways (Inhalation excludes radon) Radon Plant Meat

Milk

Soil

Radio- ÄÄÄÄÄÄÄÄÄÄÄÄÄÄÄA AАAAAÄ ÄÄÄÄÄÄÄÄ ÄÄÄÄÄA \begin{tabular}{lll} 
Co-6๑ & $1.973 \mathrm{E}+0 \odot$ & 0.0120 \\
\hline
\end{tabular} $\begin{array}{lll}\text { CS-137 } 1.591 \mathrm{E}+02 & 0.9713\end{array}$ $\mathrm{Pu}-238 \quad 6.581 \mathrm{E}-05 \quad 0.0000$ Pu-239 3.973E-04 0.0000 $\mathrm{Sb}-125 \quad 3.491 \mathrm{E}-07 \quad 0.0000$ $\begin{array}{lll}\mathrm{Sr}-90 & 1.485 \mathrm{E}-01 & 0.0009\end{array}$ Íííííí íííííííi ííííí

AAAAAAAAAAAAAAAA
АÄАĀAAAÄÄÄÄÄÄÄA АÄÄÄÄÄÄÄÄÄÄÄÄÄÄÄ mrem/yr fract. AÄÄÄÄÄÄÄÄÄÄÄÄÄÄÄ $\mathrm{mrem} / \mathrm{yr}$ fract. mrem/yr fract. AAAAAAAAA ÄÄÄÄA ÄÄÄÄÄÄÄÄÄ ÄÄÄÄÄÄ $3.502 \mathrm{E}-050.0000$ 0. OOAE+00 0 0000 $0.000 E+00 \quad 0.0000$ $0.000 \mathrm{E}+0 \odot \quad 0.0000$ $1.862 E$

$6.583 \mathrm{E}-010.0040$ $2.409 \mathrm{E}-12 \quad 0.000 \odot$ $.000 \mathrm{E}+00 \quad 0.0000$ $0.000 \mathrm{E}+00 \quad 0.0000$ 0. $000 \mathrm{E}+00$ ๑. 0000 $0.000 \mathrm{E}+0 \odot \quad 0.0000$ $0.000 \mathrm{E}+000.0000$ $0.000 \mathrm{E}+00 \quad 0.0000$ $\begin{array}{ll}0.000 E+0 \odot & 0.000 \odot \\ 0.000 E+0 \odot & 0.000 \odot\end{array}$ AAAAAAA AAAAAA $0.000 \mathrm{E}+00$ ०. 0000 $\odot .000 \mathrm{E}+0 \odot \quad 0.0000$

$0.000 \mathrm{E}+00 \quad 0.0000$ $\odot .00 \odot E+\odot \odot$ $\odot .0 \odot \odot \odot$

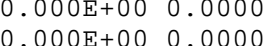
$\odot .000 E+00$ O. 0000 $9.261 E-03$ 0.0001 $0.000 \mathrm{E}+00 \quad 0.0000$ $0.000 \mathrm{E}+00 \quad 0.0000$

$8.556 \mathrm{E}-010.0052$

$0.000 \mathrm{t}$.

IIIIIIIIII Íííít

$\odot .000 \mathrm{E}+\odot \odot \odot .0000$

Total Dose Contributions $\operatorname{TDOSE}(i, p, t)$ for Individual Radionuclides ( $i)$ and Pathways $(p)$

As $\mathrm{mrem} / \mathrm{yr}$ and Fraction of Total Dose At $t=3.000 \mathrm{E}+00$ years

\section{$\odot$} Water Dependent Pathways

Water Wate
Radon
Rä̈ÄÄAAA Plant

Meat

Milk ÄÄÄÄÄÄÄÄÄÄÄÄÄÄÄÄÄ mrem/yr fract. Radio - АAAÄÄÄÄÄÄÄÄÄÄÄÄ Nuclide mrem/yr fract Äล̈ÄÄÄÄÄ ÄÄÄÄÄÄÄÄ ÄÄÄÄÄÄ $\mathrm{CS}-137$ (3) $000 \mathrm{E}+00$ - 0.0000 Pu-238 $0.000 \mathrm{E}+00$ 0.0000 $\mathrm{Pu}-2390.000 \mathrm{E}+00 \quad 0.0000$ $\mathrm{Sb}-125 \quad 0.000 \mathrm{E}+00 \quad 0.0000$ $\mathrm{Sr}-90 \quad 0.000 \mathrm{E}+0 \odot \quad 0.0000$ Íííííí íííííííí íííííi ÄÄÄÄÄÄÄÄÄÄÄÄÄÄÄÄ ÄÄÄÄÄÄÄÄÄÄÄÄÄÄÄÄ ÄÄÄÄÄÄÄÄÄÄÄÄÄÄÄ mrem/yr fract mrem/yr fract. mrem/yr fract.

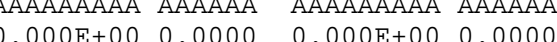
$0.000+000.0000$ $0.000 \mathrm{E}+00$ - 0.0000 $0.000 \mathrm{E}+00$ - 0.0000 $0.000 \mathrm{E}+00$ ०. $0.000 \odot$ $\odot .000 \mathrm{E}+00$ ०..000९ $\odot .000 \mathrm{E}+00 \quad 0.0000$ $\begin{array}{llll}0.000 \mathrm{E}+00 & 0.0000 & 0.000 \mathrm{E}+00 & 0.0000\end{array}$ $0.000 \mathrm{E}+00 \quad 0.0000 \quad 0.000 \mathrm{E}+00 \quad 0.0000$

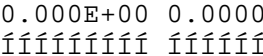
A $000 \mathrm{~A}+00$ A 0 . 0000 $0.000 \mathrm{E}+00$ - 0.0000 $\odot .000 \mathrm{E}+0 \odot \quad \odot .000 \odot$ $0.000 \mathrm{E}+000.0000$ $0.000 \mathrm{E}+000.0000$ $0.000 \mathrm{E}+00 \quad 0.0000$ íííííííí íííííi AAAAAAAAA AAAAAA $0.000 \mathrm{E}+00 \quad 0.0000$ $0.000 \mathrm{E}+00 \quad 0.0000$ $0.000 \mathrm{E}+000.0000$ $0.000 \mathrm{E}+00 \quad 0.0000$ $0.000 \mathrm{E}+00 \quad 0.0000$

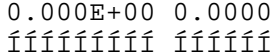
$0.000 \mathrm{E}+00 \quad 0.0000$ $\begin{array}{llll}000 \mathrm{E}+00 & 0.0000 & 6.807 \mathrm{E}-04 & 0.0000\end{array}$ . $000 \mathrm{E}+00 \quad 0.0000 \quad 4.574 \mathrm{E}-010.0028$ $\begin{array}{lllll}0.000 \mathrm{E}+00 & 0.0000 & 2.405 \mathrm{E}-01 & 0.0015\end{array}$ $\begin{array}{lllll}0.000 \mathrm{E}+00 & 0.0000 & 8.595 \mathrm{E}-01 & 0.0052\end{array}$ $\begin{array}{llll}0.000 \mathrm{E}+00 & 0.0000 & 1.003 \mathrm{E}-10 & 0.0000\end{array}$

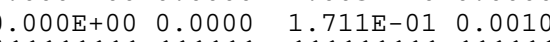
Íííííííí íííííi $\odot$ * Sum of all water independent and dependent pathways. 
Total Dose Contributions $\operatorname{TDOSE}(i, p, t)$ for Individual Radionuclides (i) and Pathways ( $p$ )

As mrem/yr and Fraction of Total Dose At $t=1.000 \mathrm{E}+01$ years

\begin{tabular}{|c|c|c|}
\hline & Grou & \\
\hline adio- & ÄÄÄÄÄÄÄÄ & 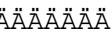 \\
\hline $\begin{array}{l}\text { Nuclide } \\
\text { ÄÄÄÄÄÄÄÄ }\end{array}$ & 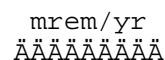 & $\begin{array}{l}\text { fract. } \\
\ddot{A} A \ddot{A} \ddot{A} A ̈ A ̈\end{array}$ \\
\hline Co- 60 & $7.678 \mathrm{E}-01$ & 0.0056 \\
\hline Cs -137 & $1.327 \mathrm{E}+02$ & $\odot .9766$ \\
\hline Pu-238 & $6.204 \mathrm{E}-05$ & $\odot .0000$ \\
\hline Pu-239 & $3.935 E-04$ & $\odot .0000$ \\
\hline$S b-125$ & $2.534 \mathrm{E}-21$ & 0.0000 \\
\hline Sr -90 & 1. $016 \mathrm{E}-01$ & 0.0007 \\
\hline Íííí́íí & Ííííííí́í & Íííííí \\
\hline Total & $1.336 \mathrm{E}+02$ & 0.9830 \\
\hline
\end{tabular}

Inhalation water Independent Pathways (Inhalation excludes radon)
Radon Plant

mrem/yr fract.
ÄÄ̈̈Ӓ̈̈̈̈̈̈̈ ÄÄÄÄÄ̈

1.320E- 05 0. 0000

$1.485 \mathrm{E}-03 \quad 0.0000$

$1.672 \mathrm{E}-010.0012$

$6.248 \mathrm{E}-010.0046$

$1.686 \mathrm{E}-260.0000$

6. $089 E-03$ 0.0000

Milk

Soil

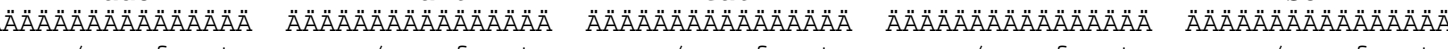
mrem/yr fract. mrem/yr fract. mrem/yr fract. mrem/yr fract. A AAAAAAAAA AAAAAA AAAAAAAAAÁ AAAAAÄA

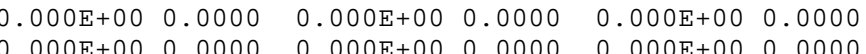
$0.000 \mathrm{E}+000.0000$ $0.000 \mathrm{E}+00 \quad 0.0000$ $0.000 \mathrm{E}+000.0000$ $.000 \mathrm{E}+00 \quad 0.0000$ $0.000 \mathrm{E}+00 \quad 0.0000$ $0.000 \mathrm{E}+000.0000$ $0.000 \mathrm{E}+00 \quad 0.0000$ $\odot .000 \mathrm{E}+00 \quad 0.0000$ $0.000 \mathrm{E}+000.0000$

$0.00 \odot E+\odot \odot \odot .00 \odot \odot$ $\begin{array}{ll}0.000 \mathrm{E}+0 \odot & 0.0000 \\ 0.000 \mathrm{E}+0 \odot & 0.0000\end{array}$ $0.000 \mathrm{E}+000.0000$ ÄÄÄÄÄÄÄÄ ÄÄÄÄÄÄ $0.000 \mathrm{E}+00 \quad 0.0000$ $0.000 \mathrm{E}+00 \quad 0.0000$ $0.000 \mathrm{E}+00 \quad 0.0000$ $0.000 \mathrm{E}+00 \quad 0.0000$ $.000 \mathrm{E}+0 \odot \quad 0.0000$ $0.000 \mathrm{E}+00 \quad 0.0000$

Íííííííi Ííííit Ííííííí ííííi

$0.000 \mathrm{E}+000.0000 \quad 0.000 \mathrm{E}+000.0000$ mrem/yr fract. ÄÄÄÄÄÄÄÄÄ ÄÄÄÄÄÄ $2.566 \mathrm{E}-04 \quad 0.0000$ $3.682 \mathrm{E}-01 \quad 0.0027$ $2.160 \mathrm{E}-010.0016$ $8.157 \mathrm{E}-010.0060$ $\begin{array}{ll}7.017 \mathrm{E}-25 & 0.0000\end{array}$ $\begin{array}{lll}1.125 \mathrm{E}-01 & 0.0008\end{array}$

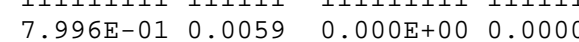

$0.000 \mathrm{E}+000.0000$

$1.513 \mathrm{E}+00$ 0. 0111

Total Dose Contributions $\operatorname{TdOSE}(i, p, t)$ for Individual Radionuclides (i) and Pathways (p)

As mrem/yr and Fraction of Total Dose At $t=1.000 \mathrm{E}+01$ years

\section{$\odot$} Water Dependent Pathways

Water Fish

Radio- Ä̈̈ÄÄ̈ÄÄË Radio AAAÄÄÄÄÄÄÄÄÄÄÄA Nuclide mrem/yr fract. $\begin{array}{lll}\text { AAAAAAA AAAAAAAAA AAAAAA } \\ \text { Co-60 } & 0.000 \mathrm{~A}+00 & 0.0000\end{array}$ CS-137 $0.000 \mathrm{E}+0 \odot \quad 0.0000$ $\mathrm{Pu}-238$ 0.000E+00 0.0000 $\mathrm{Pu}-2390.000 \mathrm{E}+0 \odot \quad 0.000 \odot$ $\mathrm{Sb}-125 \quad 0.000 \mathrm{E}+00 \quad 0.000 \odot$ Sr $-90 \quad 0.000 \mathrm{E}+00 \quad 0.0000$ íííííi íííííííi ííííí Total $0.000 \mathrm{E}+000.0000$ Radon Plant

Meat

Milk

All Pathways * ÄÄÄÄÄÄÄÄÄÄÄÄÄÄÄÄ ÄÄÄÄÄÄÄÄÄÄÄÄÄÄÄÄ ÄÄÄÄÄÄÄÄÄÄÄÄÄÄÄÄ ÄÄÄÄÄÄÄÄÄÄÄÄÄÄÄÄ mrem/yr fract. $0.000 \mathrm{E}+000.0000$ $\odot .0 \odot \odot E+\odot \odot \quad \odot .0 \odot \odot \odot$ $0.000 \mathrm{E}+00 \quad 0.0000$ mrem/yr fract. $\begin{array}{llll}0.000 E+0 \odot & 0.0000 & 0.000 \mathrm{E}+00 & 0.0000\end{array}$ $0.000 E+00 \quad 0.0000$ $0.000 E+00 \quad 0.0000$ $0.000 E+00 \quad 0.0000$ $0.000 \mathrm{E}+00 \quad 0.0000$ $0.000 \mathrm{E}+000.0000$ $\odot .000 \mathrm{E}+000.0000$

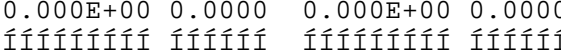
$0.000 \mathrm{E}+00 \quad 0.0000 \quad 0.000 \mathrm{E}+000.0000$ $\odot .000 \mathrm{E}+00$. mrem/yr fract. ÄÄÄÄÄÄÄÄÄ ÄÄÄÄÄÄ $\odot . \odot \odot \odot E+\odot \odot \quad \odot . \odot \odot \odot \odot$ $0.000 \mathrm{E}+000.0000$ $0.000 \mathrm{E}+00 \quad 0.0000$ $0.000 E+0 \odot \quad 0.000 \odot$ $\odot .000 \mathrm{E}+000.0000$ $0.000 \mathrm{E}+00 \quad 0.0000$ íííííííi ííííí $0.000 \mathrm{E}+0 \odot \quad 0.000 \odot$ mrem/yr fract AAAAAAAAA AAAAAA $0.000 \mathrm{E}+0 \odot$ ० 9.0000 $0.00 \odot E+\odot \odot$ ० $\odot \odot \odot$ $000+00 \quad 0.0000$ $0.000 \mathrm{E}+0 \odot \quad 0.0000$ $0.000 \mathrm{E}+0 \odot \quad 0.0000$ Iííííííi ííííi $0.000 \mathrm{E}+00 \quad 0.0000$

\section{AAAAAAAAĀÄÄÄÄÄÄ} mrem/yr fract. . $7.681 \mathrm{E}-01 \quad 0.0057$ $1.331 \mathrm{E}+02 \quad 0.9793$ $3.833 \mathrm{E}-01 \quad 0.0028$ $\begin{array}{lll}1.441 \mathrm{E}+00 & 0.0106\end{array}$ $2.535 \mathrm{E}-210.0000$ 2. $202 \mathrm{E}-010.0016$ Iííííííí ííííi $1.359 \mathrm{E}+021.0000$ 
Total Dose Contributions $\operatorname{TDOSE}(i, p, t)$ for Individual Radionuclides (i) and Pathways ( $p$ )

As mrem/yr and Fraction of Total Dose At $t=7.000 \mathrm{E}+01$ years

\begin{tabular}{|c|c|c|}
\hline & Grou & \\
\hline adio- & ÄÄÄÄÄÄÄÄ & ÄÄÄÄÄÄÄ \\
\hline $\begin{array}{l}\text { Nuclide } \\
\text { ÄÄÄÄÄÄÄÄ }\end{array}$ & 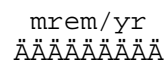 & $\begin{array}{l}\text { fract. } \\
\ddot{A} A ̈ A ̈ A ̈ A ̈ A ̈\end{array}$ \\
\hline Co- 60 & $2.121 \mathrm{E}-04$ & 0.0000 \\
\hline Cs -137 & $2.535 \mathrm{E}+01$ & $\odot .9625$ \\
\hline Pu-238 & $3.678 \mathrm{E}-05$ & $\odot . \odot \odot \odot \odot$ \\
\hline Pu-239 & $3.384 \mathrm{E}-04$ & $\odot . \odot \odot \odot \odot$ \\
\hline$S b-125$ & $\odot . \odot \odot \odot E+\odot \odot$ & $\odot . \odot \odot \odot \odot$ \\
\hline Sr -90 & $3.596 \mathrm{E}-03$ & $\odot .0 \odot \odot 1$ \\
\hline Íííí́íí & Ííííííí́í & Íííííí \\
\hline Total & $2.535 \mathrm{E}+01$ & 0.9627 \\
\hline
\end{tabular}

Inhalation water Independent Pathways (Inhalation excludes radon) Radon Meat

\begin{tabular}{|c|c|c|c|c|c|c|c|c|c|c|c|}
\hline \multicolumn{2}{|c|}{$\begin{array}{c}\text { Inhalation } \\
\text { ÄÄÄÄÄÄÄÄÄÄÄÄÄÄÄÄÄA }\end{array}$} & \multicolumn{2}{|c|}{$\begin{array}{c}\text { Radon } \\
\text { ÄÄÄÄÄÄÄÄÄÄÄÄÄÄÄ }\end{array}$} & \multicolumn{2}{|c|}{$\begin{array}{c}\text { Plant } \\
\text { ÄÄÄÄÄÄÄÄÄÄÄÄÄÄÄÄ }\end{array}$} & \multicolumn{2}{|c|}{$\begin{array}{c}\text { Meat } \\
\text { ÄÄÄÄÄÄÄÄÄÄÄÄÄÄÄÄ }\end{array}$} & \multicolumn{2}{|c|}{$\begin{array}{c}M i l k \\
\text { ÄÄÄÄÄÄÄÄÄÄÄÄÄÄÄÄ }\end{array}$} & \multicolumn{2}{|c|}{$\begin{array}{c}\text { Soil } \\
\text { ÄÄÄÄÄÄÄÄÄÄÄÄÄÄ }\end{array}$} \\
\hline & $\begin{array}{l}\text { fra } \\
\ddot{A} A ̈ \ddot{A}\end{array}$ & & $\begin{array}{l}\mathrm{fra} \\
\ddot{A} A \ddot{A}\end{array}$ & & $\begin{array}{l}\text { fract. } \\
\ddot{A ̈ A ̈ A ̈ A ̈ A ̈ A ̈ ~}\end{array}$ & & & & & & \\
\hline & & $\theta E+\odot \odot$ & & & & & & $\ominus E+\odot \odot$ & & & \\
\hline & & $+\odot \odot$ & & O & & & & $\odot \odot$ & & & \\
\hline & 22 & +00 & & 0 & & $+\odot \odot$ & & $+\odot \odot$ & & 2 & \\
\hline & & $+\odot \odot$ & & $\odot$ & & & & $+\odot \odot$ & & . & \\
\hline & & & & & & & & & & & \\
\hline & & & & & & & & & & & \\
\hline & Ííí & Eíííí & Íííí & íííí & & Íííí & Íí & Ííííí & & Íííí. & Íííííí \\
\hline-01 & & 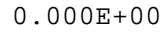 & $\odot .0 \odot \odot \odot$ & $\Theta E+\Theta \odot$ & ๑.๑००० & $\ominus \mathrm{E}+\Theta \odot$ & $\odot \odot$ & $. \odot \odot \odot E+\odot \odot$ & $0 \odot$ & $.791 \mathrm{E}-0$ & 0.0220 \\
\hline
\end{tabular}

Total Dose Contributions $\operatorname{TDOSE}(i, p, t)$ for Individual Radionuclides (i) and Pathways ( $p$ )

As $\mathrm{mrem} / \mathrm{yr}$ and Fraction of Total Dose At $t=7.000 \mathrm{E}+01$ years

\begin{tabular}{|c|c|c|c|c|c|c|c|c|c|c|c|c|c|c|}
\hline \multicolumn{15}{|l|}{$\odot$} \\
\hline$\ominus_{\mathrm{R}}$ & $\begin{array}{r}\text { Wat } \\
\triangle \ddot{A ̈ A ̈ A ̈ A ̈}\end{array}$ & $\begin{array}{l}\text { er } \\
\text { ÄÄÄÄÄÄÄ }\end{array}$ & $\begin{array}{r}\text { Fish } \\
\text { ÄÄÄAAÄÄÁ }\end{array}$ & ÄÄÄÄÄÄÄ & $\begin{array}{r}\text { Rado } \\
\text { ¿äÄÄÄÄÄÄA }\end{array}$ & 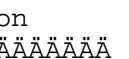 & $\begin{array}{r}P l a r \\
\text { ÄÄÄÄÄÄA }\end{array}$ & $\begin{array}{l}n t \\
\text { ÄÄÄÄÄÄÄ }\end{array}$ & $\begin{array}{r}M e a \\
\text { ÄÄÄÄÄÄÄA }\end{array}$ & 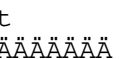 & $\begin{array}{r}M i l \\
\text { ÄÄÄÄÄÄÁ }\end{array}$ & $\begin{array}{l}\text { k } \\
\ddot{A ̈ A ̈ A ̈ A ̈ A ̈ A ̈ A ̈ ~}\end{array}$ & $\begin{array}{r}A l l \text { Pat } \\
\text { ÄÄÄÄÄÄÁ }\end{array}$ & $\begin{array}{l}\text { hways } \\
\text { ÄÄÄÄÄÄÄÄ }\end{array}$ \\
\hline $\begin{array}{l}\text { Nuclide } \\
\ddot{A} A \ddot{A} \ddot{A} \ddot{A} \ddot{A} \ddot{A}\end{array}$ & 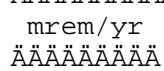 & 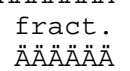 & 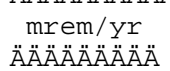 & $\begin{array}{l}\text { fract. } \\
\ddot{A} \ddot{A} \ddot{A} A \ddot{A} \ddot{A}\end{array}$ & $\begin{array}{c}m r e m / y r \\
\ddot{A} \ddot{A} \ddot{A} \ddot{A} \ddot{A} \ddot{A} \ddot{A} \ddot{A}\end{array}$ & $\begin{array}{l}\text { fract. } \\
\ddot{A} \ddot{A} \ddot{A} A \ddot{A} A ̈\end{array}$ & 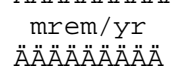 & $\begin{array}{l}\text { fract. } \\
\ddot{A} \ddot{A} A \ddot{A} \ddot{A} A ̈\end{array}$ & 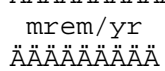 & 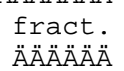 & $\begin{array}{c}m r e m / y r \\
A \ddot{A} A ̈ A ̈ A ̈ A ̈ A ̈ A ̈ A\end{array}$ & $\begin{array}{l}\text { fract. } \\
\ddot{A} \ddot{A} A \ddot{A} A \ddot{A} A\end{array}$ & 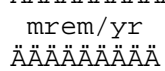 & $\begin{array}{l}\text { fract. } \\
\ddot{A} \ddot{A} \ddot{A} A \ddot{A} A ̈\end{array}$ \\
\hline Co- 60 & $0.000 \mathrm{E}+0 \odot$ & 0.0000 & $0.000 \mathrm{E}+0 \mathrm{O}$ & 0.0000 & $0.000 \mathrm{E}+00$ & 0.0000 & $0.000 \mathrm{E}+0 \odot$ & 0.0000 & $0.000 \mathrm{E}+00$ & 0.0000 & $0.000 \mathrm{E}+0 \odot$ & 0.0000 & $2.122 \mathrm{E}-04$ & 0.0000 \\
\hline Cs -137 & $\odot . \odot \odot \odot E+\odot \odot$ & 0.0000 & $0.000 \mathrm{E}+0 \odot$ & $\odot .000 \odot$ & $\odot . \odot \odot \odot E+\odot \odot$ & $\odot .0000$ & $\odot .000 \mathrm{E}+\odot \odot$ & 0.0000 & $\odot .0 \odot \odot E+\odot \odot$ & 0.0000 & $\odot E+\odot \odot$ & 0.0000 & $E+01$ & 0.9644 \\
\hline Pu-238 & $0.000 \mathrm{E}+0 \odot$ & 0.0000 & $0.000 \mathrm{E}+00$ & 0.0000 & $\odot .000 \mathrm{E}+0 \odot$ & 0.0000 & $\ominus \odot E+\Theta \odot$ & 0.0000 & $\Theta \mathrm{E}+\Theta \odot$ & 0.0000 & $0 \mathrm{E}+00$ & 0.0000 & 1.3 & 0.0050 \\
\hline Pu-239 & $0.000 \mathrm{E}+0 \odot$ & 0.0000 & $0.000 \mathrm{E}+0 \odot$ & 0.0000 & $\Theta \mathrm{E}+0 \odot$ & 0. & $E+\odot \odot$ & 0. & $E+00$ & 0. & $E+\odot \odot$ & 0.0000 & -01 & 0.0303 \\
\hline Sb-125 & $\odot .000 \mathrm{E}+0 \odot$ & 0.0000 & $0.000 \mathrm{E}+0 \odot$ & 0.0000 & $\odot . \odot \odot \odot E+\odot \odot$ & $\odot .0000$ & $\odot .000 \mathrm{E}+\odot \odot$ & $0.000 \odot$ & $\odot .00 \odot \mathrm{E}+\odot \odot$ & 0.0000 & $\odot .000 \mathrm{E}+0 \odot$ & 0.0000 & $0.000 \mathrm{E}+00$ & 0.0000 \\
\hline $\mathrm{Sr}-90$ & $\odot .000 \mathrm{E}+0 \odot$ & 0.0000 & $0.000 \mathrm{E}+0 \odot$ & 0.0000 & $\odot . \odot \odot \odot E+\odot \odot$ & $\odot .0000$ & $\odot . \odot \odot \odot E+\odot \odot$ & 0.0 & $\odot E+\odot \odot$ & 0. & $\Theta$. & 0. & -03 & $\odot \odot 2$ \\
\hline Ííííííi & Íííííííí & Íííííí & Íííííííí & Íííííí & éííín & & & & & & & & Íí & \\
\hline Total & $0.000 \mathrm{E}+00$ & 0.0000 & $0.000 \mathrm{E}+00$ & 0.0000 & $0.000 \mathrm{E}+00$ & 0.0000 & $0.000 \mathrm{E}+00$ & 0.0000 & $0.000 \mathrm{E}+00$ & 0.0000 & $0.000 \mathrm{E}+00$ & 0.0000 & $2.634 \mathrm{E}+01$ & 1.0000 \\
\hline
\end{tabular}

$\odot^{*}$ Sum of all water independent and dependent pathways. 
Total Dose Contributions $\operatorname{TDOSE}(i, p, t)$ for Individual Radionuclides (i) and Pathways ( $p$ )

As mrem/yr and Fraction of Total Dose At $t=1.000 \mathrm{E}+02$ years Nuclide mrem/yr fract.

AAAAAAÄ ÄÄÄÄÄÄÄÄ ÄÄÄÄÄA

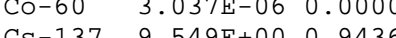

$\mathrm{Pu}-238 \quad 2.746 \mathrm{E}-05 \quad 0.0000$

Pu-239 2.810E-04 0.0000

$\mathrm{Sb}-125 \quad 0.000 \mathrm{E}+00 \quad 0.0000$

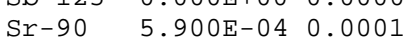

Íííííí íííííííi ííííí Inhalation Water Independent Pathways (Inhalation excludes radon) Plant Meat

Milk

Soil

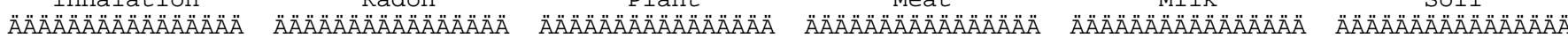
mrem/yr fract. mrem/yr fract. mrem/yr fract. mrem/yr fract.

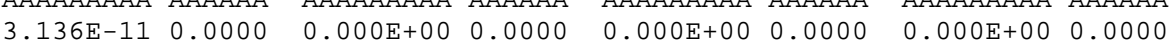

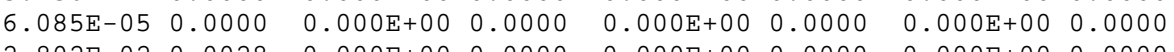
$0.000 \mathrm{E}+00 \quad 0.0000$ $0.000 \mathrm{E}+0 \odot \quad 0.0000$ $0.000 E+00 \quad 0.0000$ $0.000 \mathrm{E}+00 \quad 0.0000$ $0.000 \mathrm{E}+00 \quad 0.0000$ $0.000 \mathrm{E}+00 \quad 0.0000$ $1.847 \mathrm{E}-05 \quad 0.0000$ $0.000 \mathrm{E}+000.0000$ $0.000 \mathrm{E}+000.0000$

$0.000 \mathrm{E}+000.0000$ $0.000 \mathrm{E}+0 \odot$ ०. $0.00 \odot$ $\odot .000 \mathrm{E}+\odot \odot$ $\odot .000 \odot$ ๑. $000 E+00$ \% $\odot .000 \odot$

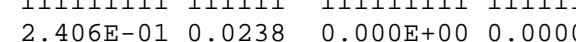

$0.000 \mathrm{E}+000.0000$ mrem/yr fract. ÄÄÄÄÄÄÄÄÄ ÄÄÄÄÄÄ $\odot . \odot \odot \odot E+\odot \odot \quad \odot . \odot \odot \odot \odot$ $0.000 \mathrm{E}+00 \quad 0.0000$ $0.000 \mathrm{E}+00 \quad 0.0000$ $0.000 \mathrm{E}+000.0000$ $0.000 \mathrm{E}+00 \quad 0.0000$ $0.000 \mathrm{E}+00 \quad 0.0000$

IIIIIÍííi Ííííí

$\odot .000 \mathrm{E}+0 \odot$ ० 0.0000 ÄÄÄÄÄÄÄÄÄ ÄÄÄÄÄÄ $6.095 \mathrm{E}-10 \quad 0.0000$ $1.509 \mathrm{E}-020.0015$ $3.619 \mathrm{E}-02 \quad 0.0036$ $2.775 \mathrm{E}-01 \quad 0.0274$ $\odot .000 \mathrm{E}+00 \quad 0.0000$ $3.413 \mathrm{E}-04 \quad 0.0000$ $3.291 \mathrm{E}-01$ iliti $\mathrm{mrem} / \mathrm{yr}$ fract.

Total Dose Contributions $\operatorname{TDOSE}(i, p, t)$ for Individual Radionuclides (i) and Pathways (p)

As mrem/yr and Fraction of Total Dose At $t=1.000 \mathrm{E}+02$ years

$\odot$ Water Dependent Pathways

Water

Fish Radon Plant

Meat

Milk Radio - АAАAАÄÄÄÄÄÄÄAA

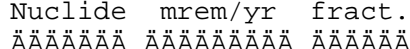
Co-6० $0.000 \mathrm{E}+0 \odot \quad 0.0000$ Cs-137 $0.000 \mathrm{E}+00 \quad 0.0000$ Pu-238 $0.000 \mathrm{E}+00 \quad 0.0000$ Pu-239 $0.000 \mathrm{E}+0 \odot \quad 0.00 \odot \odot$ $\mathrm{Sb}-125 \quad 0.00 \odot \mathrm{E}+\odot \odot \quad \odot .00 \odot \odot$ Sr-90 $0.000 \mathrm{E}+00 \quad 0.0000$ Ifíííí ífííííí ííííi mrem/yr fract. mrem/yr fract. mrem/yr fract. ÄÄÄÄÄÄÄÄÄÄÄÄÄÄ
mrem/yr fract. AAAAAAAAA AAAAAAA $0.000 \mathrm{E}+00^{\circ}, 0000$ $\odot .000 \mathrm{E}+0 \odot \quad 0.0000$ ÄÄÄÄÄÄÄÄÄ ÄÄÄÄÄĂ $\odot .0 \odot \odot E+\odot \odot ~ \odot . \odot \odot \odot \odot$ $\odot .000 \mathrm{E}+0 \odot \quad 0.0000$ $0.000 \mathrm{E}+00 \quad 0.0000$ $0.000 \mathrm{E}+00 \quad 0.0000$ $0.000+00$.

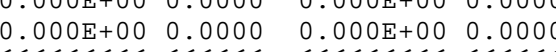
Ííííííí ííííi IÍíííííí ííííí ÄÄÄÄÄÄÄÄÄ ÄÄÄÄÄÄ

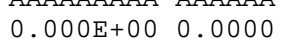
$0.000 E+00 \quad 0.0000$ $\odot .000 \mathrm{E}+0 \odot \quad \odot .000 \odot$ $0.000 \mathrm{E}+00 \quad 0.0000$ $\odot .000 \mathrm{E}+0 \odot \quad \odot .0000$ $0.000 \mathrm{E}+00 \quad 0.0000$ íííííííi ííííí AAAAAAAA AAAAAAA $0.000+000.000$ $0.000 \mathrm{E}+00 \quad 0.0000$ $0.000 \mathrm{E}+0 \odot \quad 0.000 \odot$ $0.000 \mathrm{E}+00 \quad 0.0000$ $0.000 \mathrm{E}+00 \quad 0.0000$ íííííííi ííííí $\odot$ * Sum of all water independent and dependent pathways.

ÄAAAAAAAAÄAAAA All pathways* mrem/yr fract. AAAAAAAAÁ AAAAAÁ $0.000 \mathrm{E}+00 \quad 0.0000$ $0.000 \mathrm{E}+0 \odot \quad 0.0000$ $.000 E+0 \odot \quad 0.0000$ $0.000 \mathrm{E}+00 \quad 0.0000$ $0.000 \mathrm{E}+00 \quad 0.0000$ $0.000 \mathrm{E}+00 \quad 0.0000$ Iííííííi Ííííi $0.000 \mathrm{E}+000.0000$ 
Total Dose Contributions $\operatorname{TDOSE}(i, p, t)$ for Individual Radionuclides (i) and Pathways ( $p$ )

As $\mathrm{mrem} / \mathrm{yr}$ and Fraction of Total Dose At $t=3.000 \mathrm{E}+02$ years

$\odot$ Nuclide mrem/yr fract.

AАÄÄÄA ÄÄÄÄÄÄÄÄ ÄÄÄÄÄA

Cs-137 $0.000 \mathrm{E}+00 \quad 0.0000$

$\mathrm{Pu}-238 \quad 0.000 \mathrm{E}+000.0000$

Pu-239 $0.000 \mathrm{E}+00 \quad 0.0000$

$\mathrm{Sb}-125 \quad 0.000 \mathrm{E}+00 \quad 0.0000$

Sr $-90 \quad 0.000 \mathrm{E}+00 \quad 0.0000$

íííííi ííííííí ííííí Inhalation Water Independent Pathways (Inhalation excludes radon) Plant Meat

Milk

Soil

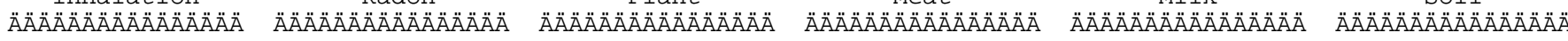
mrem/yr fract. mrem/yr fract. mrem/yr fract. mrem/yr fract.

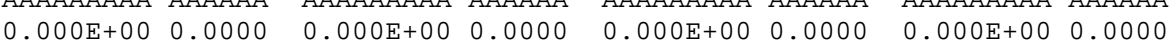

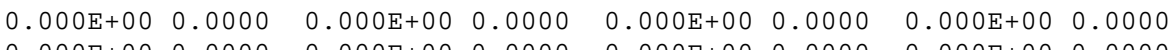
$\odot .000 \mathrm{E}+0 \odot \quad 0.000 \odot$ $0.000 \mathrm{E}+00 \quad 0.0000$ $.000 \mathrm{E}+0 \odot \quad 0.00 \odot \odot$ $0.000 \mathrm{E}+0 \odot \quad 0.00 \odot$ $\odot .000 E+00$ \% $\odot .0000$ $0.000 \mathrm{E}+0 \odot \quad 0.0000$ $0.000 \mathrm{E}+00 \quad 0.0000$ $0.000 \mathrm{E}+00 \quad 0.0000$ $\odot .000 \mathrm{E}+0 \odot \quad 0.000 \odot$

$\odot .000 \mathrm{E}+\odot \odot$ ०. $0.0 \odot \odot$ $0.000 \mathrm{E}+0 \odot$ ०. $0.00 \odot$ $\odot .000 \mathrm{E}+\odot \odot$ $\odot .000 \odot$ ๑. $000 E+00$ \% $\odot .0000$

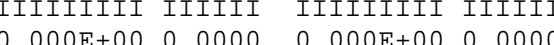

$0.000 \mathrm{E}+\odot \odot \quad 0.000 \odot$ mrem/yr fract. ÄÄÄÄÄÄÄÄÄ ÄÄÄÄÄÄ $\odot . \odot \odot \odot E+\odot \odot \quad \odot . \odot \odot \odot \odot$ $0.000 \mathrm{E}+0 \odot \quad 0.0000$ $0.000 \mathrm{E}+00 \quad 0.0000$ $0.000 \mathrm{E}+0 \odot \quad 0.0000$ $0.000 \mathrm{E}+00 \quad 0.0000$ $0.000 \mathrm{E}+00 \quad 0.0000$

IIIIIIIIíí Ííííí

$\odot .0 \odot \odot \mathrm{E}+\odot \odot$ $\odot . \odot \odot \odot \odot$ $0.000 \mathrm{E}+000.0000$ $0.000 E+00 \quad 0.0000$ $\odot .000 \mathrm{E}+00$ ०. 0000

Total Dose Contributions $\operatorname{TDOSE}(i, p, t)$ for Individual Radionuclides (i) and Pathways $(p)$

As $\mathrm{mrem} / \mathrm{yr}$ and Fraction of Total Dose At $t=3.000 \mathrm{E}+02$ years

\section{$\odot$} Water Dependent Pathways

Water

Fish Radon Plant Meat
ÄÄÄÄÄÄÄÄÄÄÄÄÄÄÄÄ

Milk

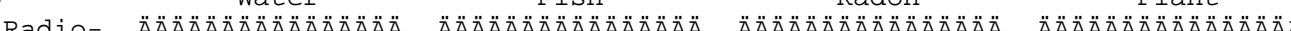
Radio AAAAAÄAÄÄÄÄÄÄAA

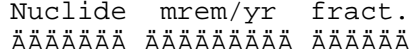
Co-6० $0.000 \mathrm{E}+0 \odot \quad 0.0000$ Cs-137 $0.000 \mathrm{E}+00 \quad 0.0000$ $\mathrm{Pu}-238 \quad 0.000 \mathrm{E}+00 \quad 0.0000$ Pu-239 $0.000 \mathrm{E}+0 \odot \quad 0.00 \odot \odot$ $\mathrm{Sb}-125 \quad 0.000 \mathrm{E}+00 \quad 0.0000$ Sr-90 $\quad 0.000 \mathrm{E}+00 \quad 0.0000$ ÍÍíííí íííííííi ííííí mrem/yr fract. AAAAĀÄÄÄÄÄÄÄÄÄA AลÄÄÄÄÄÄÄÄÄÄÄÄÄÄ ÄÄÄÄÄÄÄÄÄÄÄÄÄÄÄÄ
mrem/yr fract. AAAAAAAAA AAAAAAA $\odot . \odot \odot \odot E+\odot \odot$ ०. $\odot \odot \odot \odot$ $\odot .000 \mathrm{E}+0 \odot \quad 0.000 \odot$ ÄÄÄÄÄÄÄÄ ÄÄÄÄÄÄ $0.000 \mathrm{E}+00 \quad 0.0000$ $0.000 \mathrm{E}+000.0000$ (1) $0.000 \mathrm{E}+00 \quad 0.0000$

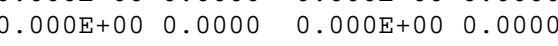
$\begin{array}{llll}0.000 \mathrm{E}+00 & 0.0000 & 0.000 \mathrm{E}+00 & 0.0000\end{array}$ Ííííííí ííííí ííííííí ííííí AAAAAAAA AAAAAA AAAAAAAAA AAAAAA $0.000 \mathrm{E}+00 \quad 0.0000$ $0.000 \mathrm{E}+0 \odot \quad 0.000 \odot$ $0.000 \mathrm{E}+000.0000$ $0.000 \mathrm{E}+00 \quad 0.0000$ $0.000 \mathrm{E}+0 \odot \quad 0.0000$ $9.000+\odot \odot$ O. $0.000 \mathrm{E}+00 \quad 0.0000$ $0.000 \mathrm{E}+0 \odot \quad 0.000 \odot$ $0.00 \odot \mathrm{E}+0 \odot \odot .000 \odot$ \begin{tabular}{lll}
$0.000 \mathrm{E}+\odot \odot$ & $0.000 \odot$ \\
\hline $.000 \mathrm{E}+0 \odot$ & $0.000 \odot$
\end{tabular}

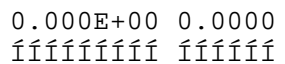
$\odot *$ Sum of all water independent and dependent pathways. Aล̈ÄÄÄÄÄÄÄÄÄÄÄÄÄ $\mathrm{mrem} / \mathrm{yr}$ fract. AAAAAAAAA ÄÄÄÄÄA $\odot .000 \mathrm{E}+00$ - 0.0000 $0.000 \mathrm{E}+00$ - 0.0000 $0.000 \mathrm{E}+000.0000$ $0.000 \mathrm{E}+00 \quad 0.0000$ $\odot . \odot \odot \odot E+\odot \odot \quad \odot . \odot \odot \odot \odot$ Ííííííííi íííííi 
Total Dose Contributions $\operatorname{TDOSE}(i, p, t)$ for Individual Radionuclides (i) and Pathways ( $p$ )

As mrem/yr and Fraction of Total Dose At $t=1.000 \mathrm{E}+03$ years

\begin{tabular}{|c|c|c|}
\hline & & \\
\hline$\theta$ & Grou & \\
\hline Radio- & ÄÄÄÄÄÄÄÄÄÄ & $\triangle$ \\
\hline $\begin{array}{l}\text { Nuclide } \\
\text { ÄÄÄÄÄÄÄÄ }\end{array}$ & 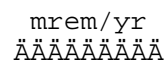 & $\begin{array}{l}\text { fract. } \\
\ddot{A} \ddot{A} \ddot{A} A \ddot{A} \ddot{A}\end{array}$ \\
\hline $\mathrm{Co}-60$ & $\odot .000 \mathrm{E}+0 \odot$ & 0.0000 \\
\hline Cs -137 & $\odot . \odot ० \odot E+\odot \odot$ & 0.0000 \\
\hline Pu-238 & $\odot . \odot \odot \odot E+\odot \odot$ & $0.000 \odot$ \\
\hline Pu-239 & $\odot . \odot \odot \odot E+\odot \odot$ & $\odot .0 \odot \odot \odot$ \\
\hline Sb-125 & $\odot . \odot \odot \odot E+\odot \odot$ & $\odot .000 \odot$ \\
\hline $\mathrm{Sr}-90$ & $\odot .00 \ominus \mathrm{E}+\Theta \odot$ & 0.0000 \\
\hline ÍÍííííí & ÍÍííí́ííí & Íííííí \\
\hline Total & $\odot . \odot \odot \odot E+\odot \odot$ & $\odot .000 \odot$ \\
\hline
\end{tabular}

Inhalation Water Independent Pathways (Inhalation excludes radon)
Radon

Milk

Soil

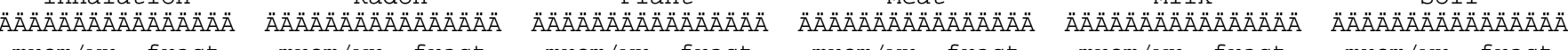

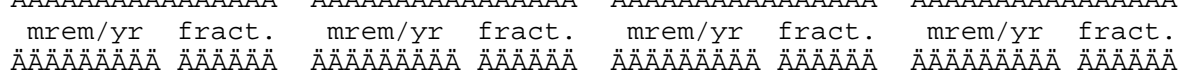

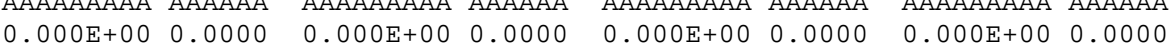

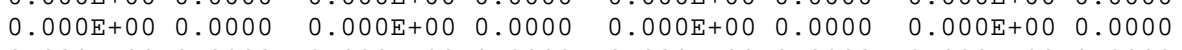

$0.000 \mathrm{E}+00 \quad 0.0000 \quad 0.000 \mathrm{E}+00$ 0. 0000

$0.000 \mathrm{E}+000.0000$

.

$\odot .000 \mathrm{E}+0 \odot \quad 0.0000$

$0.000 \mathrm{E}+000.00000$

$\odot .000 \mathrm{E}+0 \odot \quad 0.000 \odot$

$0.000 \mathrm{E}+0 \odot$ ०. 0.0000

$\odot .00 \odot \mathrm{E}+\odot \odot$ ०. $.000 \odot$

$0.000 \mathrm{E}+000.0000$

$0.000 \mathrm{E}+00 \quad 0.0000$

$\begin{array}{ll}0.000 E+00 & 0.0000 \\ \text { Íííííí ÍÍííi }\end{array}$

ÍIíííííi Ííííi

Ííííííi ííííi

$\odot .000 \mathrm{E}+0 \odot$ ० 0000

$\odot .0 \odot \odot \mathrm{E}+0 \odot \quad 0.00 \odot$

$0.000 \mathrm{E}+00 \quad 0.0000$

mrem/yr fract.

AAAAAAAAA ÄÄÄÄÄ

$0,000 \mathrm{E}+00$ - 0.0000

$0.000 \mathrm{E}+00 \quad 0.0000$

$0.000 \mathrm{E}+00 \quad 0.0000$

$0.000 \mathrm{E}+00 \quad 0.0000$

$0.000 \mathrm{E}+000.0000$

$0.000 \mathrm{E}+0 \odot$ 0. 0000 mrem/yr fract. ÄÄÄÄÄÄÄÄ ÄÄÄÄÄ $0.000 \mathrm{E}+00 \quad 0.0000$ $\odot .000 \mathrm{E}+00 \quad 0.0000$ $0.000 E+00 \quad 0.0000$ $\odot .000 \mathrm{E}+000.0000$ $\odot .000 \mathrm{E}+00 \quad 0.0000$ $\odot . \odot \odot \odot E+\odot \odot \quad \odot . \odot \odot \odot \odot$ $\odot .00 \odot \mathrm{E}+0 \odot$ Q 0000

Total Dose Contributions TDOSE( $i, p, t)$ for Individual Radionuclides (i) and Pathways (p)

As mrem/yr and Fraction of Total Dose At $t=1.000 \mathrm{E}+03$ years

\section{$\odot$}

Water Fish

Radio- ÄÄÄÄ̈̈̈̈̈̈ Radio AAAAÄÄÄÄÄÄÄÄÄÄ Nuclide mrem/yr fract. $\begin{array}{lll}\text { AAAAAAA AAAAAAAA AAAAAA } \\ \text { Co-60 } & 0.000 \mathrm{~A}+00 & 0.0000\end{array}$ CS-137 $0.000 \mathrm{E}+00 \quad 0.0000$ PU-238 $0.000 \mathrm{E}+00 \quad 0.0000$ Pu-239 $0.000 \mathrm{E}+00 \quad 0.0000$ $\mathrm{Sb}-125 \quad 0.000 \mathrm{E}+00 \quad 0.000 \odot$ $\begin{array}{ccc}\mathrm{Sr}-90 & 0.000 \mathrm{E}+00 & 0.0000\end{array}$ Íííííí íííííííí íííííi

Total $0.000 \mathrm{E}+000.0000$ Water Dependent Pathways Radon Water Dependent Pat
Plant

\section{ÄÄÄÄÄÄÄÄÄÄÄÄÄÄÄÄ} mrem/yr fract.

$0.000 \mathrm{E}+00$ - 0.0000

$\odot .000 \mathrm{E}+0 \odot \quad 0.000 \odot$

$0.000 \mathrm{E}+00 \quad 0.0000$

$\odot .00 \odot \mathrm{E}+\odot \odot \quad \odot .00 \odot \odot$

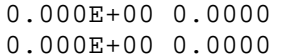

ííííííí ÍÍÍÍ

$0.000 \mathrm{E}+00 \quad 0.0000$

ÄÄÄÄÄÄÄÄÄÄÄÄÄÄÄÄ

Äล̈ÄÄÄÄÄÄÄÄÄÄÄÄÄÄÄ mrem/yr fract. mrem/yr fract. Ä̈̈̈̈̈̈̈̈̈̈̈̈̈̈ ÄÄÄÄÄÄ ÄÄÄÄÄÄÄÄ ÄÄÄÄÄÄ $\odot .000 \mathrm{E}+00 \quad 0.0000$ $.000 E+0 \odot$ O. 0000 $0.000 \mathrm{E}+0 \odot \quad 0.000 \odot$ $0.000 E+00 \quad 0.0000$ $0.000 E+00 \quad 0.0000$ $0.000 \mathrm{E}+00 \quad 0.0000$ IIÍÍÍÍÍí ÍÍÍÍÍI $0.000 \mathrm{E}+00 \quad 0.0000$ $0.000 \mathrm{E}+0 \odot \quad 0.0000$ $\odot .000 \mathrm{E}+0 \odot \quad \odot .000 \odot$ $0.000 \mathrm{E}+0 \odot \quad 0.0000$ $\odot .000 \mathrm{E}+0 \odot \quad \odot .0000$ $0.000 \mathrm{E}+00 \quad 0.0000$ Íííííííí ííííí ÄÄÄÄÄÄÄÄÄ ÄÄÄÄÄÄ $\odot .000 \mathrm{E}+0 \odot \quad 0.0000$ $\odot .0 \odot \odot E+\odot \odot \quad 0.0 \odot \odot \odot$ $0.000 \mathrm{E}+00 \quad 0.0000$ $0.000 \mathrm{E}+00 \quad 0.0000$ $0.000 \mathrm{E}+00 \quad 0.0000$ $0.000 \mathrm{E}+00 \quad 0.0000$ Íííííííi ííííí $0.000 \mathrm{E}+00 \quad 0.0000$
Milk АÄ̈AÄÄÄÄÄÄÄÄÄÄÄ mrem/yr fract

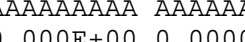
$0.000 \mathrm{E}+0 \odot$ ० 0.0000 $0.000 \mathrm{E}+00 \quad 0.0000$ $0.000 \mathrm{E}+00 \quad 0.0000$ $0.000 E+00 \quad 0.0000$ $0.000 \mathrm{E}+00 \quad 0.0000$ IÍíííííi íííí $0.000 \mathrm{E}+00 \quad 0.0000$ of all water independent and dependent pathways. 
Dose/Source Ratios Summed Over All Pathways

Parent and Progeny Principal Radionuclide Contributions Indicated

oparent Product Branch

\begin{tabular}{|c|c|c|c|c|c|c|c|c|c|c|}
\hline $\begin{array}{c}(i) \\
\text { ÄÄÄÄÄÄÄÄ }\end{array}$ & $\ddot{A} A \ddot{A} \ddot{A} \ddot{A} A \ddot{A}$ & $\begin{array}{l}\text { Fraction* } \\
\text { ÄÄÄÄÄÄÄÄÄA }\end{array}$ & 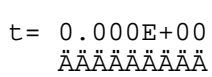 & 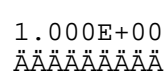 & ÄÄÄÄÄÄÄÄÄ & ÄÄÄÄÄÄÄÄÄ & $\triangle A A A A A A A A A A$ & ÄÄÄÄÄÄÄÄÄ & ӒÄÄÄÄÄÄÄÄ & ÄÄÄÄÄÄÄÄÄ \\
\hline Co- 60 & $\mathrm{Co}-60$ & 1. $000 \mathrm{E}+\odot \odot$ & $4.782 \mathrm{E}-01$ & 4. $180 \mathrm{E}-01$ & $3.193 E-01$ & $1.243 \mathrm{E}-01$ & $3.433 E-05$ & 4. $915 \mathrm{E}-07$ & $0.000 \mathrm{E}+0 \odot$ & $0.000 \mathrm{E}+\odot \odot$ \\
\hline Cs - 137 & Cs -137 & $1 . \odot \odot \odot E+\odot \odot$ & $1.127 \mathrm{E}-01$ & $1.098 \mathrm{E}-01$ & 1. $043 \mathrm{E}-01$ & $8.699 \mathrm{E}-02$ & $1.660 \mathrm{E}-\odot 2$ & $6.251 \mathrm{E}-03$ & $\odot . \odot \odot \odot E+\odot \odot$ & $\odot . \odot \odot \odot E+\odot \odot$ \\
\hline & & & & & & & & & & \\
\hline Pu-238 & $U-234$ & 1. $\odot \odot \odot E+\odot \odot$ & $1.043 \mathrm{E}-08$ & $3.074 \mathrm{E}-08$ & $6.901 \mathrm{E}-08$ & $1.802 \mathrm{E}-07$ & $3.234 \mathrm{E}-07$ & $1.986 \mathrm{E}-07$ & $\odot . \odot \odot \odot E+\odot \odot$ & $\ominus \mathrm{E}+\odot \odot$ \\
\hline Pu-238 & Th-230 & $1 . \odot \odot \odot E+\odot \odot$ & $7.321 \mathrm{E}-14$ & $5.058 \mathrm{E}-13$ & $2.595 \mathrm{E}-12$ & $2.083 \mathrm{E}-11$ & $3.294 \mathrm{E}-10$ & $3.328 \mathrm{E}-10$ & $E+\odot \odot$ & $\odot . \odot \odot \odot E+\odot \odot$ \\
\hline Pu-238 & $\mathrm{Ra}-226$ & 1.6 & -16 & 2.5 & -14 & 13 & 11 & 10 & $+\odot \odot$ & $+0 \odot$ \\
\hline 38 & $\mathrm{~Pb}-210$ & 1.0 & $4 \mathrm{E}-19$ & $4.240 \mathrm{E}-18$ & 1. $024 \mathrm{E}-16$ & $845 \mathrm{E}-15$ & $3.296 \mathrm{E}-12$ & $5.670 \mathrm{E}-12$ & $\odot . \odot \odot \odot E+\odot \odot$ & $\odot . \odot \odot \odot E+\odot \odot$ \\
\hline Pu-238 & äDSR $(j)$ & & & 3.6 & $3.586 \mathrm{E}-02$ & $1 E-\odot 2$ & $E-02$ & $5.398 \mathrm{E}-\odot 3$ & $E+\odot \odot$ & $\ominus \mathrm{E}+\odot \odot$ \\
\hline OPu-239 & $\mathrm{Pu}-239$ & 1.00 & $-\odot 2$ & 4.1 & $\odot 2$ & 02 & 02 & -02 & +00 & $E+0 \odot$ \\
\hline Pu-239 & $U-235$ & 1. $\odot \odot \odot E+\odot \odot$ & LE-11 & $4.964 \mathrm{E}-11$ & $1.133 \mathrm{E}-10$ & $.149 \mathrm{E}-10$ & 1. $059 \mathrm{E}-09$ & $9.639 \mathrm{E}-10$ & $E+\odot \odot$ & $\odot . \odot \odot \odot E+\odot \odot$ \\
\hline Pu-239 & $\mathrm{Pa}-231$ & 1. $\odot \odot \odot E+\odot \odot$ & E-16 & $3.095 \mathrm{E}-15$ & $1.579 \mathrm{E}-14$ & . $242 \mathrm{E}-13$ & $1.675 \mathrm{E}-12$ & $1.587 \mathrm{E}-12$ & $E+\odot \odot$ & $\odot . \odot \odot \odot E+\odot \odot$ \\
\hline Pu-239 & AC -227 & 1. $\odot \odot \odot E+\odot \odot$ & & -16 & $E-15$ & & & $E-12$ & $+\odot \odot$ & $E+\odot \odot$ \\
\hline Pu-239 & äDSR $(j)$ & & $=-02$ & 4.11 & 4. $059 \mathrm{E}-02$ & $853 E-\odot 2$ & 02 & LE- -02 & $+\odot \odot$ & $E+\odot \odot$ \\
\hline OSb-125 & $S b-125$ & 1. $\odot \odot \odot E+\odot \odot$ & $1.772 \mathrm{E}-02$ & $1.693 \mathrm{E}-04$ & $1.545 E-08$ & $1.121 \mathrm{E}-22$ & $\odot \odot \odot E+\odot \odot$ & $\odot . \odot \odot \odot E+\odot \odot$ & $\odot . \odot \odot \odot E+\odot \odot$ & $\odot . \odot \odot \odot E+\odot \odot$ \\
\hline & & $1.0 \mathrm{C}$ & & & & & & & & \\
\hline & & İíí & IÍííííí & 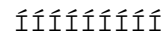 & 60 & & & Íííííí & 111 & Íí \\
\hline
\end{tabular}

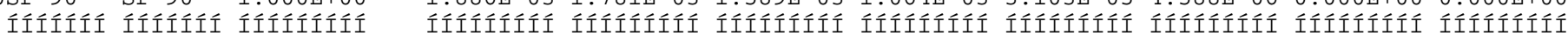

${ }^{*}$ Branch Fraction is the cumulative factor for the $j$ 't principal radionuclide daughter: $\operatorname{CUMBRF}(j)=\operatorname{BRF}(1){ }^{*} \operatorname{BRF}(2){ }^{*} \ldots \operatorname{BRF}(j)$.

$\odot$

Single Radionuclide Soil Guidelines $G(i, t)$ in $p C i / g$

Basic Radiation Dose Limit $=2.500 \mathrm{E}+01 \mathrm{mrem} / \mathrm{yr}$

onuclide

(i) $\quad \mathrm{t}=0.000 \mathrm{E}+00$

ÄÄÄÄÄÄÄ ÄÄÄÄÄÄÄÄ

Co-60 5.228E+01

$\begin{array}{ll}\mathrm{Cs}-137 & 2.219 \mathrm{E}+02 \\ \mathrm{Pu}-238 & 6.663 \mathrm{E}+02\end{array}$

$\mathrm{Pu}-238$

$1.000 \mathrm{E}+00$

\section{$3 . \odot \odot \odot E+\odot \odot$}

AAAAA

ÄÄÄÄÄÄÄÄA

1. $000 \mathrm{E}+01$

7. $\odot \odot \odot E+\odot 1$

1. $000 \mathrm{E}+02$

3. $000 \mathrm{E}+02 \quad 1.000 \mathrm{E}+03$

$5.981 \mathrm{E}+01$

$7.829 \mathrm{E}+01$

AAAAAAAAA

ÄÄÄÄÄÄÄÄÄ

Ӓล̈ล̈ล̈ÄÄÄÄÄ

$\ddot{A} \dddot{\circ}$

$2.011 \mathrm{E}+02 \quad 7.282 \mathrm{E}+05$

5. $086 \mathrm{E}+07$

*1.131E+15

ÄÄÄÄÄÄÄÄÄ

$6.764 \mathrm{E}+02$

$6.972 \mathrm{E}+02$

$\begin{array}{ll}7.874 \mathrm{E}+02 & 1.506 \mathrm{E}+03 \\ 7.761 \mathrm{E}+02 & 2.246 \mathrm{E}+03\end{array}$

$3.999 \mathrm{E}+03 * 8.701 \mathrm{E}+13 * 8.701 \mathrm{E}+13$

$6.027 \mathrm{E}+02 \quad 6.070 \mathrm{E}+\mathrm{O} 2$

6. $159 \mathrm{E}+02$

$6.489 \mathrm{E}+02 \quad 1.171 \mathrm{E}+03$

$4.632 \mathrm{E}+03 \quad * 1.711 \mathrm{E}+13$

$8.701 \mathrm{E}+13-8.701 \mathrm{E}+13$

$\mathrm{Sb}-125 \quad 1.411 \mathrm{E}+03-1.477 \mathrm{E}+05$

$\mathrm{Sr}-90 \quad 1.326 \mathrm{E}+04 \quad 1.404 \mathrm{E}+04$

$1.618 \mathrm{E}+09$

$6.489 \mathrm{E}+02$

$1.171 \mathrm{E}+03$

* $1.711 \mathrm{E}+13$

$1.574 \mathrm{E}+04$

$2.350 \mathrm{E}+04 \quad 8.058 \mathrm{E}+05 \quad 5.449 \mathrm{E}+06$

8. $058 \mathrm{E}+05$

$1.033 \mathrm{E}+15$

*1. $133 E+15 * 1.212 E+10$

ÍIIIííi İíííííí Ííííííít

ÍÍíííííí

* $1.033 \mathrm{E}+15$

* $1.033 \mathrm{E}+15$

*At specific activity limit

íííííííi ííííííín ííííííít

Ííííííí́

\section{Uncontrolled When Printed}


Summed Dose/Source Ratios DSR(i,t) in (mrem/yr)/(pCi/g)

and Single Radionuclide Soil Guidelines $\mathrm{G}(\mathrm{i}, \mathrm{t})$ in $\mathrm{pCi} / \mathrm{g}$

at $\mathrm{tmin}=$ time of minimum single radionuclide soil guideline

and at $\operatorname{tmax}=$ time of maximum total dose $=0.000 \mathrm{E}+00$ years

\begin{tabular}{|c|c|c|c|c|c|c|}
\hline $\begin{array}{l}\text { uclide } \\
\text { (i) }\end{array}$ & $\begin{array}{l}\text { Initial } \\
\text { (pCi/g) }\end{array}$ & $\begin{array}{l}\text { tmin } \\
\text { years) }\end{array}$ & $\operatorname{DSR}(i, \operatorname{tmin})$ & $\begin{array}{r}\mathrm{G}(\mathrm{i}, \mathrm{tmin}) \\
(\mathrm{p} \mathrm{i} / \mathrm{g})\end{array}$ & $\operatorname{DSR}(i, \operatorname{tmax})$ & $\begin{array}{r}\mathrm{G}(\mathrm{i}, \mathrm{tmax}) \\
(\mathrm{p} \mathrm{c} / \mathrm{g})\end{array}$ \\
\hline & & ÄÄÄÄÄÄÄÄÄÄÄÄÄÄ & ÄÄÄÄÄÄÄÄÄÄ & ÄÄÄÄÄÄÄÄÄ & ÄÄÄÄÄÄÄÄÄÄ & $\ddot{A} \ddot{A} \ddot{A}$ \\
\hline Co- 60 & $6.180 \mathrm{E}+0 \odot$ & $\odot . \odot \odot \odot E+\odot \odot$ & $4.782 \mathrm{E}-01$ & $5.228 \mathrm{E}+01$ & $4.782 \mathrm{E}-01$ & $5.228 \mathrm{E}+01$ \\
\hline Cs -137 & $1.530 \mathrm{E}+03$ & $\odot .000 \mathrm{E}+0 \odot$ & $1.127 \mathrm{E}-01$ & 2.21 & $1.127 \mathrm{E}-01$ & $E+02$ \\
\hline Pu-238 & $1.190 \mathrm{E}+01$ & $\odot . \odot \odot \odot E+\odot \odot$ & $3.752 E-02$ & $6.663 \mathrm{E}+02$ & $3.752 E-02$ & $6.663 \mathrm{E}+02$ \\
\hline Pu-239 & $3.740 E+01$ & $\odot . \odot \odot \odot E+\odot \odot$ & $4.148 E-02$ & $6.027 \mathrm{E}+02$ & $4.148 \mathrm{E}-02$ & $6.027 \mathrm{E}+02$ \\
\hline 125 & $2.260 E+01$ & $\odot . \odot \odot \odot E+\odot \odot$ & -02 & 1.41 & $E-02$ & $E+03$ \\
\hline $\mathrm{Sr}-90$ & 2.07 & 0.0 & 1. & 1.3 & -03 & 1.3 \\
\hline Íííííít & Ííííííít & íííííííííííííí & Ííííííííí & Íííííííít & Ííííííííi & Íííííííít \\
\hline
\end{tabular}


onuclide Parent BRF(i) (j) (i) ÄÄÄÄÄÄÄ ÄÄÄÄÄÄÄ ӒÄÄÄÄÄÄÄ

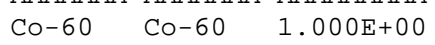
๑Cs-137 CS $-137 \quad 1.000 \mathrm{E}+\odot \odot$ OU-234 Pu-238 1. $000 \mathrm{E}+00$

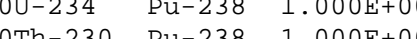
TTh-230 $\mathrm{Pu}-238 \quad 1.000 \mathrm{E}+00$ ORa-226 Pu-238 $1.000 \mathrm{E}+00$ $\odot \mathrm{Pb}-210 \mathrm{Pu}-238 \quad 1.000 \mathrm{E}+\odot$ ०Pu-239 Pu-239 1.000E+०0

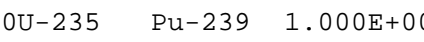
๑AC-227 PU-239 1. $000 \mathrm{E}+\odot 0$ ๑Sb-125 Sb-125 1. $00 \odot \mathrm{E}+\odot 0$

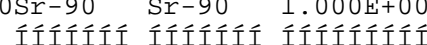
OPu-238 Pu-238 1. $1000 \mathrm{E}+00$ $\odot \mathrm{Pa}-231 \mathrm{Pu}-239$ 1. $200 \mathrm{E}+\odot \odot$ OSr $-90 \mathrm{Sr}-90$ - $1.000 \mathrm{C}+00$

Individual Nuclide Dose Summed Over All Pathways Parent Nuclide and Branch Fraction Indicated $\operatorname{DOSE}(j, t), m r e m / y r$

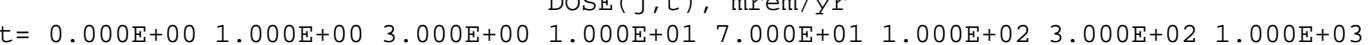
ÄÄÄÄÄÄÄÄÄ ÄÄÄÄÄÄÄÄÄ ÄÄÄÄÄÄÄÄÄ ÄÄÄÄÄÄÄÄÄ ÄÄÄÄÄÄÄÄÄ

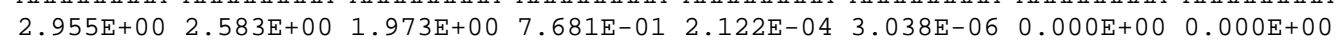

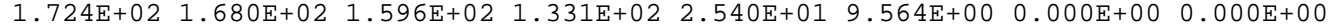
$\begin{array}{llllllll}4.465 \mathrm{E}-01 & 4.398 \mathrm{E}-01 & 4.267 \mathrm{E}-01 & 3.833 \mathrm{E}-01 & 1.325 \mathrm{E}-01 & 6.423 \mathrm{E}-02 & 0.000 \mathrm{E}+00 & 0.000 \mathrm{E}+00\end{array}$

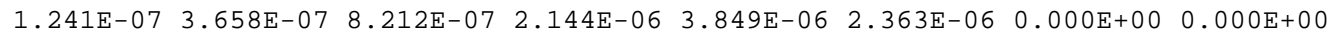

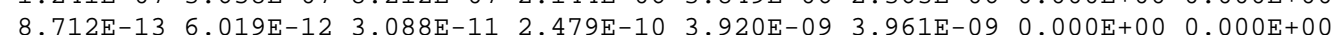

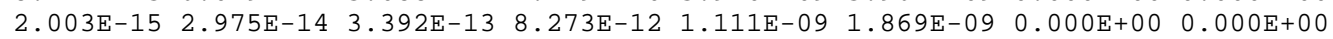

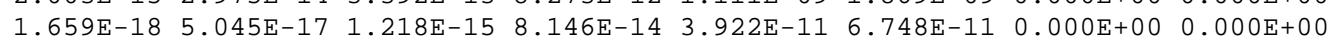

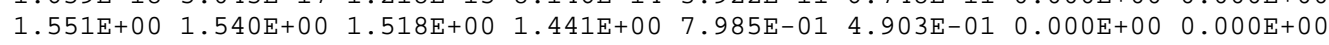
6.249E-10 1.857E-09 4.239E-09 1.178E-08 3.962E-08 3.605E-08 $0.000 \mathrm{E}+00$ ๑. 1.680E-14 1.158E-13 5.906E-13 4.647E-12 6.266E-11 5.936E-11 $0.000 \mathrm{E}+00$ ๑. 4.546E-16 6.628E-15 7.256E-14 1.533E-12 7.388E-11 8.156E-11 $0.000 \mathrm{E}+00$ 0.000E+००

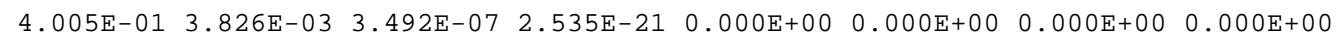

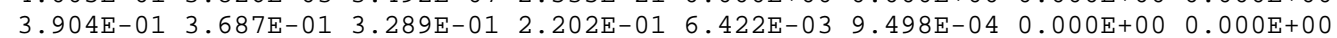

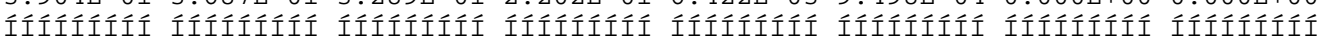
$\operatorname{BRF}(i)$ is the branch fraction of the parent nuclide. 
Individual Nuclide Soil Concentration

onuclide Parent BRF(i) (j) (i)

ÄÄÄÄÄÄÄ ÄÄÄÄÄÄÄ ÄÄÄÄÄÄÄÄÄ

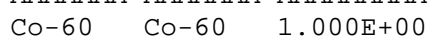
๑CS -137 Cs $-137 \quad 1.000 \mathrm{E}+00$

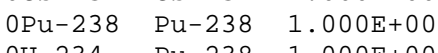
OU -234 Pu-238 $1.000 \mathrm{E}+00$ OTh-230 $\mathrm{Pu}-238 \quad 1.000 \mathrm{E}+00$ ORa-226 Pu-238 $1.000 \mathrm{E}+00$ $\odot \mathrm{Pb}-210 \mathrm{Pu}-238 \quad 1.000 \mathrm{E}+\odot 0$ ०Pu-239 Pu-239 1.000E+०0 $\odot \mathrm{OU}-235$ Pu-239 $1.000 \mathrm{E}+\odot \odot$

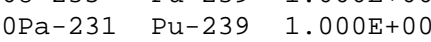
๑AC-227 Pu-239 1. $1.000 \mathrm{E}+00$ $\odot \mathrm{Sb}-125 \mathrm{Sb}-125 \quad 1.00 \Theta \mathrm{E}+\Theta 0$ $\begin{array}{lll}O S r-90 & \mathrm{Sr}-90 & 1.000 \mathrm{E}+00\end{array}$ íííííi íííííi íííííííi

$\operatorname{BRF}(i)$ is the branch fraction ORESCALC. EXE execution time =
Parent Nuclide and Branch Fraction Indicated

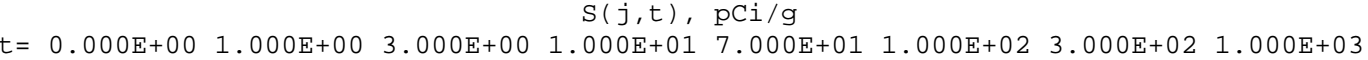

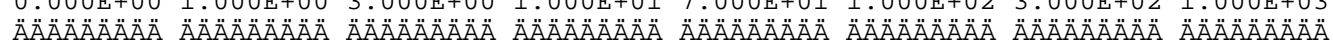

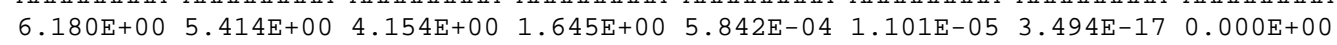

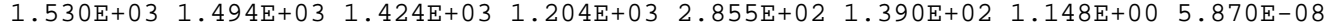

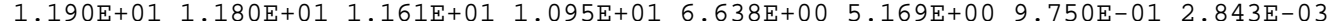

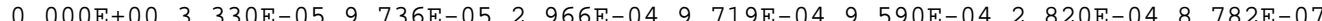
$\odot . \odot \odot \odot \mathrm{E}+\odot \odot \quad 1.505 \mathrm{E}-10 \quad 1.332 \mathrm{E}-09 \quad 1.394 \mathrm{E}-08 \quad 4.196 \mathrm{E}-07 \quad 6.826 \mathrm{E}-07 \quad 1.757 \mathrm{E}-06 \quad 2.038 \mathrm{E}-06$

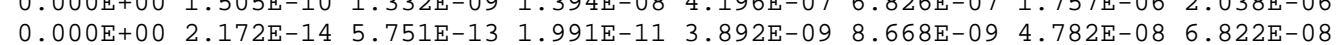

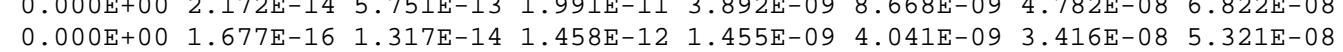

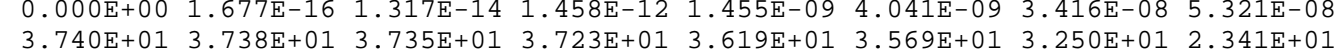

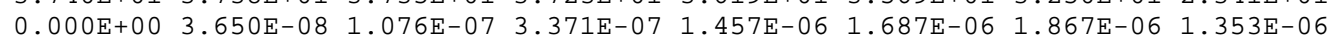
$0.000 \mathrm{E}+00$ 3.851E-13 3.385E-12 3.465E-11 8.690E-10 1.300E-09 2.243E-09 1.678E-09 $0.000 \mathrm{E}+00 \quad 4.022 \mathrm{E}-15 \quad 1.028 \mathrm{E}-13 \quad 3.159 \mathrm{E}-12 \quad 2.804 \mathrm{E}-10 \quad 4.705 \mathrm{E}-10 \quad 9.450 \mathrm{E}-10 \quad 7.131 \mathrm{E}-10$

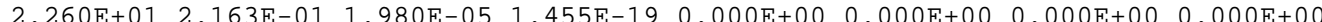

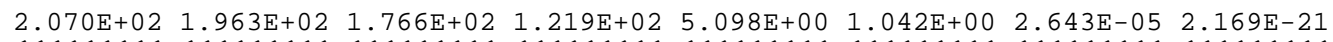

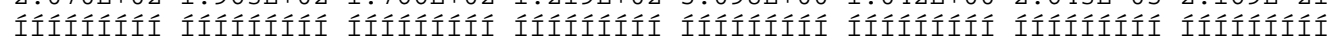
of the parent nuclide. 4.12 seconds 


\section{Appendix E}

Closure Summary

Uncontrolled When Printed 


\section{E.1.0 Closure Summary}

A land-use restriction (LUR) will be applied as part of the closure in place alternative for CAU 559, T-Tunnel Compressor/Blower Pad. The LUR will be applied to control use and limit access to the site to prevent inadvertent exposure to the TPH-DRO contaminated soil identified on the pad. The LUR will be part of the closure of CAU 476, T-Tunnel Muckpile. A separate LUR will not be established to cover the CAU 559, Compressor/Blower Pad, unless the closure of CAU 476 does not require a use restriction.

This site can be closed without further corrective action. 


\section{LIBRARY DISTRIBUTION LIST}

U.S. Department of Energy

National Nuclear Security Administration

Nevada Site Office

Technical Library

P.O. Box 98518, M/S 505

Las Vegas, NV 89193-8518

U.S. Department of Energy

Office of Scientific and Technical Information

P.O. Box 62

Oak Ridge, TN 37831-0062

Southern Nevada Public Reading Facility

c/o Nuclear Testing Archive

P.O. Box 98521, M/S 400

Las Vegas, NV 89193-8521

Manager, Northern Nevada FFACO

Public Reading Facility

c/o Nevada State Library \& Archives

Carson City, NV 89701-4285
1 (Uncontrolled, electronic copy)

1 (Uncontrolled, electronic copy)

2 (Uncontrolled, electronic copies)

1 (Uncontrolled, electronic copy) 